ENVIRONMENTAL RESTORATION PROGRAM

\title{
Survey of Protected Vascular Plants on the Oak Ridge Reservation, Oak Ridge, Tennessee
}

\author{
RECEVISD \\ JUL 19 个9 \\ OSTI
}

This document has been approved by the K-25 Site Technical Information Office for release to the public. Date: $6 / 25 / 96$

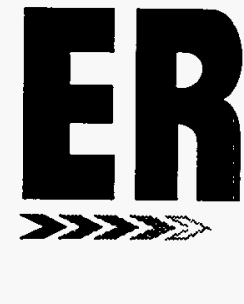


Author and Contributor Affiliations

J. Awl, Larry R. Pounds, and Barbara Rosensteel are subcontractors with JAYCOR Environmental. Amy L. King, Program Manager, is I member of Computational Physics and Engineering, Oak Ridge National Laboratory. Patricia A. Hamlett is a subcontractor vith the University of Tennessec.

This report has been reproduced directly from the best available copy.

Available to DOE and DOE contractors from the Office of Scientific and Technical Information, P.O. Box 62, Oak Ridge, TN 37831; prices available from 423-576-8401 (fax 42.3-576-2865).

Available to the public from the National Technical Information Service, U.S. Department of Commerce, 5285 Pit Royal Rd., Springfield, VA 22161. 


\title{
Survey of Protected Vascular Plants on the Oak Ridge Reservation, Oak Ridge, Tennessee
}

\author{
D. J. Awl \\ L. R. Pounds \\ B. A. Rosensteel \\ A. L. King \\ P. A. Hamlett \\ Environmental Restoration Division \\ P.O. Box 2003 \\ Oak Ridge, Tennessee 37831-7294
}

Date Issued-June 1996

\author{
Prepared for the \\ U.S. Department of Energy \\ Office of Environmental Management \\ under budget and reporting code EW 20 \\ LOCKHEED MARTIN ENERGY SYSTEMS, INC. \\ managing the \\ Environmental Management Activities at the \\ Oak Ridge K-25 Site Paducah Gaseous Diffusion Plant \\ Oak Ridge Y-12 Plant Portsmouth Gaseous Diffusion Plant \\ Oak Ridge National Laboratory \\ under contract DE-AC05-84OR21400 \\ for the \\ U.S. DEPARTMENT OF ENERGY
}





\section{DISCLAIMER}

Portions of this document may be illegible in electronic image products. Images are produced from the best available original document. 


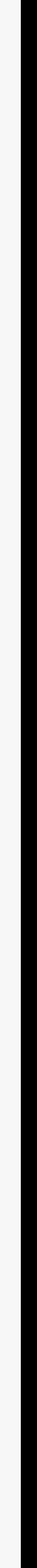




\section{PREFACE}

This technical report was prepared as the final report of the Threatened and Endangered Vascular Plants Project of the Environmentally Sensitive Areas Surveys Program. This work was conducted under Work Breakdown Structure 1.4.12.2.3.04.03.01 (Activity Data Sheet 8304) and the milestone titled Final Report of Baseline Threatened and Endangered Vascular Plant Species Conditions on the Oak Ridge Reservation.

\section{DISCLAIMER}

This report was prepared as an account of work sponsored by an agency of the United States Government. Neither the United States Government nor any agency thereof, nor any of their employees, makes any warranty, express or implied, or assumes any legal liability or responsibility for the accuracy, completeness, or usefulness of any information, apparatus, product, or process disclosed, or represents that its use would not infringe privately owned rights. Reference herein to any specific commercial product, process, or service by trade name, trademark, manufacturer, or otherwise does not necessarily constitute or imply its endorsement, recommendation, or favoring by the United States Government or any agency thereof. The views and opinions of authors expressed herein do not necessarily state or reflect those of the United States Government or any agency thereof. 


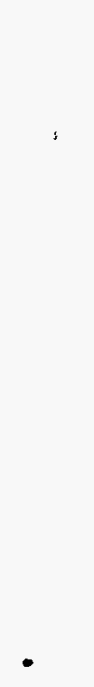




\section{ACKNOWLEDGEMENTS}

Thanks to Pat Parr and Robin Graham, Oak Ridge National Laboratory (ORNL), for administrative support. Nancy Hendrix-Ward and Suzanne P. Riddle from the U.S. Department of Energy are responsible for the continued funding of this program. The threatened and endangered plant survey team members were Deborah Awl (JAYCOR), Rebecca Cook (University of Tennessee), Larry Pounds.(JAYCOR), Barbara Rosensteel (JAYCOR), and Beth Wade. Thanks to Cindy Gabrielsen (ORNL), Jim Evans (TWRA), Jason Mitchell (JAYCOR), Elizabeth Vail (JAYCOR), Warren Webb (ORNL), and Bruce Zerr (Oak Ridge Y-12 Plant) for information concerning habitats on the Oak Ridge Reservation. The following experts provided technical assistance in the identification of plant specimens: Dr. Vern McNeilus, Dr. Hal De Selm and Dr. Eugene Wofford of the University of Tennessee Herbarium and Dr. Charles Sheviak of the New York State Museum. Thanks to Mylo Pyne formerly with the Tennessee Department of Environment and Conservation and presently with The Nature Conservancy) and Carl Nordman ( Tennessee Department of Environment and Conservation) for providing information concerning the Tennessee state-list; Mylo Pyne assisted with compiling Oak Ridge Reservation threatened and endangered vascular plant records during 1994 as part of the Common Ground Initiative. 


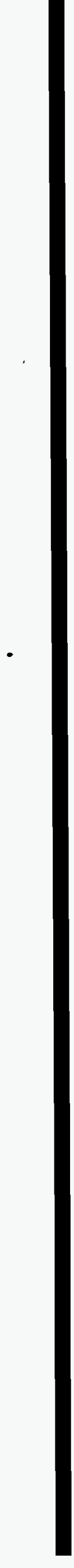




\section{CONTENTS}

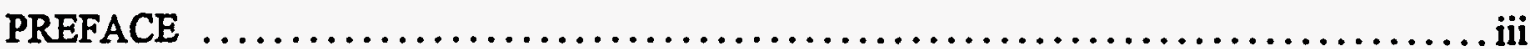

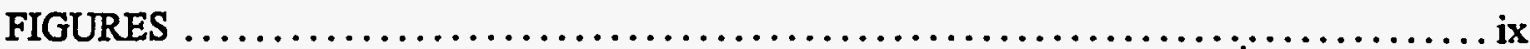

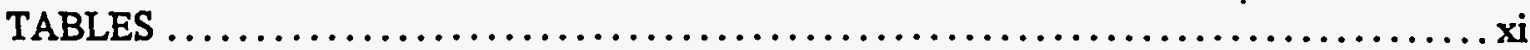

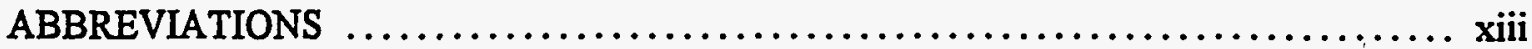

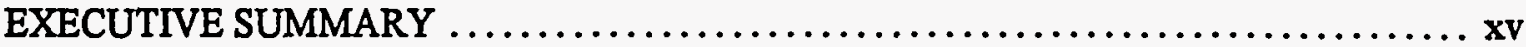

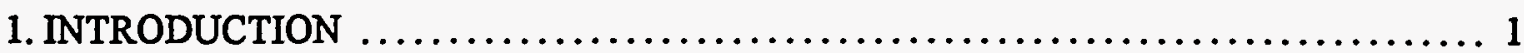

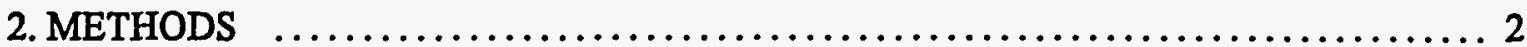

2.1. COMPILATION OF PRE-EXISTING DATA $\ldots \ldots \ldots \ldots \ldots \ldots \ldots \ldots \ldots, 2$

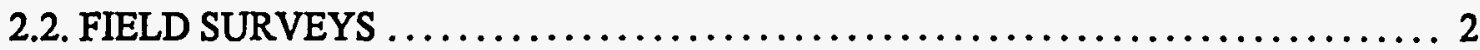

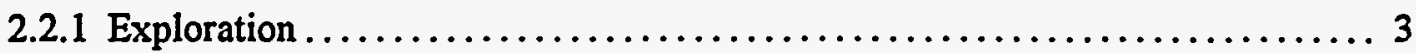

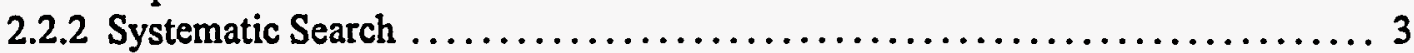

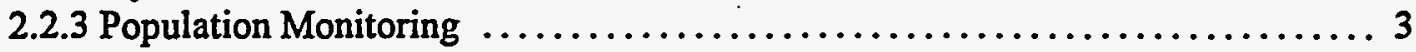

2.3 DOCUMENTATION $\ldots \ldots \ldots \ldots \ldots \ldots \ldots \ldots \ldots \ldots \ldots \ldots \ldots \ldots \ldots, 4$

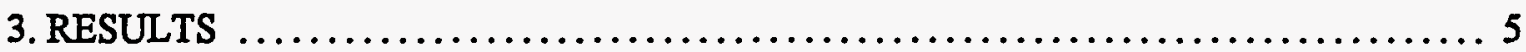

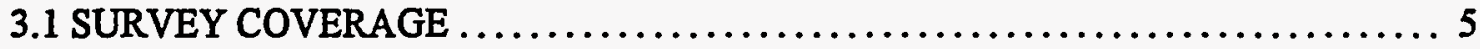

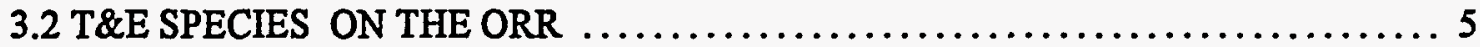

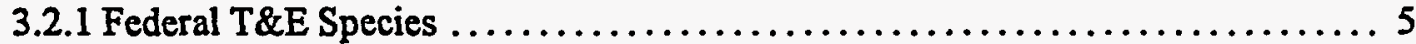

3.2.2 Tennessee T\&E Species ................................... 5

3.2.3 Other T\&E Species Which May Be Present on the ORR ................ 6

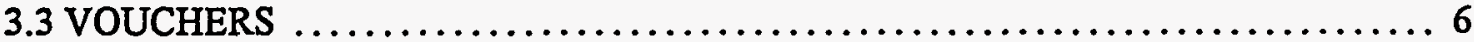

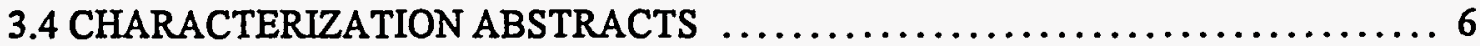

3.4.1 T\&E Vascular Plant Species Found on the ORR $\ldots \ldots \ldots \ldots \ldots \ldots \ldots \ldots, 6$

3.4.1.1 Aureolaria patula (Chapm.) Pennell ........................ 6

3.4.1.2 Carex gravida Bailey ................................ 7

3.4.1.3 Carex howei Mack (Carex atlantica L.H.Bailey var. capillacea

(L.H.Bailey) Reznicek ) ................................. 8

3.4.1.4 Carex oxylepis Torr. \& Hook. var. pubescens J.K.Underw. ......... 9

3.4.1.5 Cimicifuga rubifolia Kearney ............................. 10

3.4.1.6 Collinsonia verticillata Baldwin ex Elliot ................... 11

3.4.1.7 Cypripedium acaule Ait. ............................... 11

3.4.1.8 Delphinium exaltatum Ait. ............................ 12

3.4.1.9 Diervilla lonicera P. Mill. ............................. 13

3.4.1.10 Draba ramosissima Desv. .............................. 14

3.4.1.11 Elodea nuttallii (Planch.) St. John ........................ 15

3.4.1.12 Fothergilla major (Sims) Lodd. ....................... 15

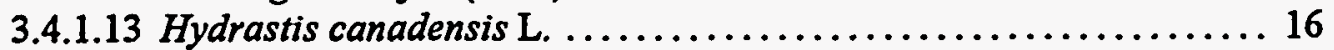

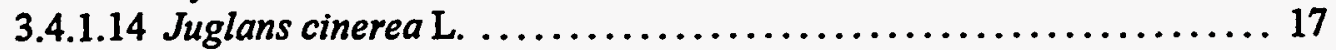

3.4.1.15 Juncus brachycephalus (Engelm.) Buchenau ................ 18

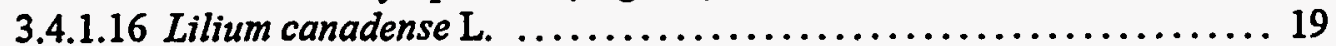

3.4.1.17 Lilium michiganense Farw. .......................... 20

3.4.1.18 Liparis loeselii (L.) L. C. Rich ....................... 20

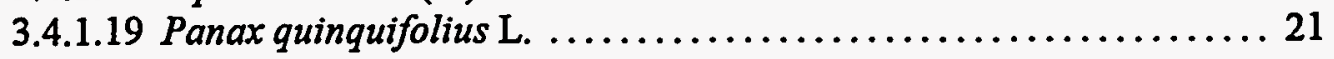


3.4.1.20 Platanthera flava var. herbiola (R.Br.) Luer ............... 23

3.4.1.21 Platanthera peramoena (A.Gray) A.Gray ................ 23

3.4.1.22 Pycnanthemum verticillatum (Michx.) Pers. (species cluster) ...... 24

3.4.1.23 Rhynchospora colorata (L.) Pfeiffer .................... 25

3.4.1.24 Ruellia purshiana Fern. ........................... 26

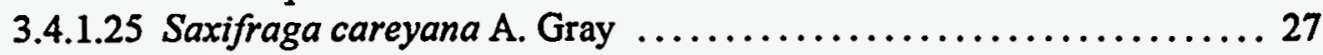

3.4.1.26 Scirpus fluviatilis (Torr.) A. Gray ...................... 28

3.4.1.27 Spiranthes lucida (H. Eaton) Ames .................... 28

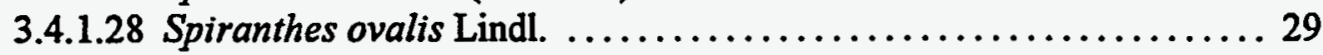

3.4.1.29 Viola tripartita Elliot var. tripartita ................... 30

3.4.2 Additional T\&E Vascular Plant Species that Occur Near and May Be

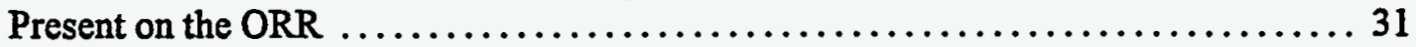

3.4.2.1 Berberis canadensis Mill. ............................ 31

3.4.2.2 Gnaphalium helleri Britt. ............................... 31

3.4.2.3 Liatris cylindracea Michx. .......................... 32

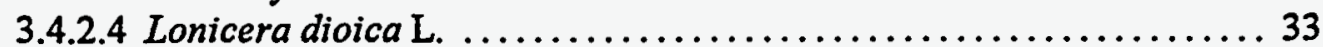

3.4.2.5 Meehania cordata (Nutt.) Britt. ........................... 33

3.4.2.6 Pedicularis lanceolata Michx. ........................... 34

3.4.2.7 Solidago ptarmicoides (Nees) Boivin ................... 34

3.4.2.8 Tomanthera auriculata (Michx.) Raf. .................... 35

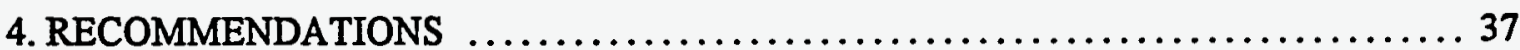

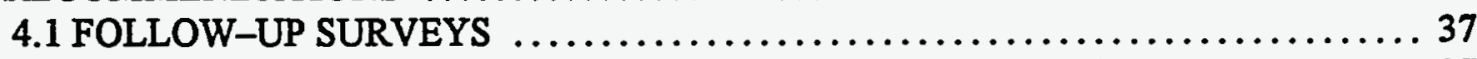

4.1.1 Future Surveys at Environmental Restoration Remediation Sites .......... 37

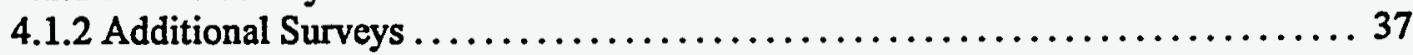

4.2 MAINTENANCE AND UPDATE OF DATA BASES AND VOUCHER

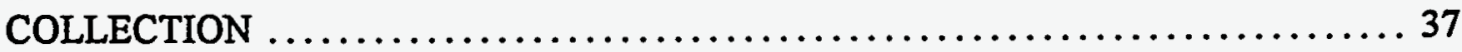

4.3 AVOIDANCE OF ORR ENVIRONMENTALLY SENSITIVE AREAS $\ldots \ldots \ldots \ldots . . . . .$.

4.4 IMPACT ASSESSMENT $\ldots \ldots \ldots \ldots \ldots \ldots \ldots \ldots \ldots \ldots \ldots \ldots \ldots \ldots \ldots \ldots \ldots \ldots \ldots \ldots \ldots \ldots$

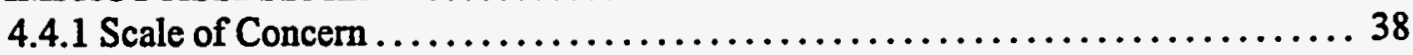

4.4.2 Threats to T\&E Vascular Plant Species ...................... 38

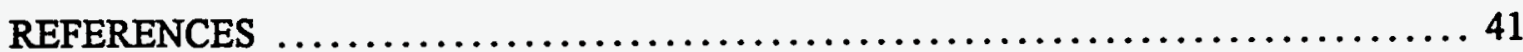

Appendix:

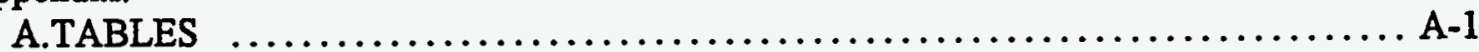

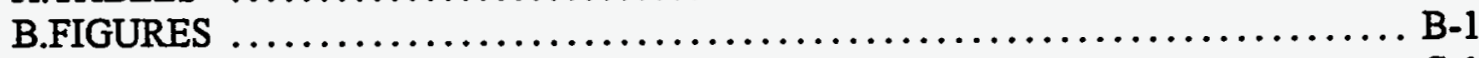

C.ORR VASCULAR FLORA DATA BASE $\ldots \ldots \ldots \ldots \ldots \ldots \ldots \ldots \ldots \ldots \ldots \ldots . . .1$ 


\section{FIGURES}

1. T\&E vascular plant surveys on the ORR, fiscal years $1992-1996 \ldots \ldots \ldots \ldots \ldots \ldots$. . . 3

2. T\&E vascular plant surveys on the ORR by survey number, $1995-1996 \ldots \ldots \ldots \ldots \ldots$.

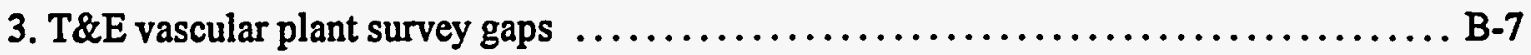

4. Point locations of listed vascular plant species on the ORR (including OU boundaries) .. B-9

5. Environmentally sensitive areas on the ORR containing T\&E species ............ B-11 


\section{TABLES}

1. T\&E vascular plant surveys on the ORR, fiscal years $1992-1994$, summary data ....... A-3

2. T\&E Vascular plant surveys on the ORR fiscal years $1995-1996$, summary data ....... A-6

3. Vascular plant species found on the Oak Ridge Reservation which are listed by State or federal agencies (includes both common and scientific names) ............ A-19

4. Occurrence of listed vascular plant species in OUs, WAGs, environmentally Sensitive areas, and other areas on the ORR

5. T\&E species potentially occurring on the ORR A-26

6. Additions to the Oak Ridge Vascular Flora, 1992-1996 A-28

7. ORNL photography numbers for photographs of listed vascular plant species A-33

8. U.S. State abbreviations A-36

9. Exotic plant species associated with adverse impact to T\&E Species or with high potential to adversely impact $T \& E$ species 



\section{ABBREVIATIONS}

CERCLA Comprehensive Environmental Response, Compensation, and Liability Act

CFR

CWA

DOE

EM

ESA

FWS

GIS

GWOU

NEPA

NRDA

OREIS

ORNL

ORR

OU

T\&E

TDEC

TNC

TVA

UT

WAG
Code of Federal Regulations

Clean Water Act

U.S. Department of Energy

Environmental Restoration and Waste Management Program

Endangered Species Act

U. S. Fish and Wildlife Service

geographic information systems

groundwater operable unit

National Environmental Policy Act

National Resource Damage Assessments

Oak Ridge Environmental Information System

Oak Ridge National Laboratory

Oak Ridge Reservation

operable unit

threatened and endangered

Tennessee Department of Environment and Conservation

The Nature Conservancy

Tennessee Valley Authority

The University of Tennessee

waste area grouping 


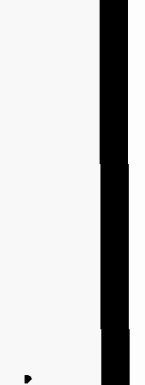




\section{EXECUTIVE SUMMARY}

Vascular plant surveys were initiated during fiscal year 1992 by the environmentally sensitive areas program to determine the baseline condition of threatened and endangered (T\&E) vascular plant species on the Oak Ridge Reservation (ORR). T\&E species receive protection under federal and state regulations. In addition, the National Environmental Policy Act (NEPA) requires that federally-funded projects avoid or mitigate impacts to listed species.

T\&E plant species found on or near the U. S. Department of Energy's (DOE) Oak Ridge Reservation (ORR) are identified. Twenty-eight species identified on the ORR are listed by the Tennessee Department of Environment and Conservation as either endangered, threatened, or of special concern. Four of these have been under review by the U.S. Fish and Wildlife Service for possible listing (listed in the formerly-used C2 candidate category). Additional species listed by the state occur near and may be present on the ORR. A range of habitats support the rare taxa on the ORR: river bluffs, sinkholes, calcareous barrens, wetlands, utility corridors, and forests. The list of T\&E plant species and their locations on the ORR should be considered provisional because the entire ORR has not been surveyed, and state and federal status of all species continues to be updated.

The purpose of this document is to present information on the listed T\&E plant species currently known to occur on the ORR as well as listed species potentially occurring on the ORR based on geographic range and habitat availability. For the purpose of this report, "T\&E species" include all federal- and state-listed species, including candidates for listing, and species of special concern. For project planning purposes, this report is most useful in alerting planners and site managers that T\&E species are known to exist in certain areas. Consideration of T\&E plant habitats is an important component of resource management and land-use planning; protection of rare species in their natural habitat is the best method of ensuring their long-term survival. 



\section{INTRODUCTION}

The U.S. Department of Energy's (DOE's) Oak Ridge Reservation (ORR) encompasses approximately 15,000 ha in the Ridge and Valley physiographic province of Tennessee. Threatened and endangered (T\&E) plant species on the ORR may receive protection under federal and state laws.

The federal Endangered Species Act of 1973 (ESA), as amended, provides for the listing and protection of species in danger of becoming extinct and conservation of the habitats on which such species depend. ESA makes it illegal to kill, collect, remove, harass, import, or export an endangered or threatened species without a permit from the Secretary of the Interior. Federal regulations that implement Sect. 7, "Interagency Cooperation," of the ESA (16 U.S.C. 1531 et seq.) require federal agencies to assess the impacts of their actions on plant and animal species listed by the U. S. Fish and Wildlife Service (FWS) as threatened or endangered and on areas designated or proposed for designation as critical habitat. FWS recommends that federal agencies also consider species that are candidates for listing during environmental planning since candidate species may eventually be listed.

The National Environmental Policy Act (NEPA) requires that federally-funded projects avoid or mitigate impacts to listed species. DOE NEPA implementing regulations (10 CFR 1021) require consideration of adverse affects to "environmentally sensitive resources" including "federally listed threatened or endangered species or their habitat (including critical habitat), federally proposed or candidate species or their habitat, or state-listed endangered or threatened species or their habitat."

Plant species listed by the Tennessee Department of Environment and Conservation (TDEC) are also provided limited protection by the Tennessee Rare Plant Protection and Conservation Act of 1985 (Tennessee Code Annotated Title 11-26, Sects. 201-214). This act protects listed plant species from removal or destruction without the consent of the landowner. DOE supports the protection of state-listed species on the ORR.

The DOE Environmental Restoration and Waste Management Program (EM) has supported a program to survey the ORR for species listed as T\&E. Vascular plant surveys were initiated during fiscal year 1992 by the Environmentally Sensitive Areas Program to determine the baseline condition of $T \& E$ vascular plant species on the ORR. The primary concern of the T\&E plant survey project is the identification of vascular plant species occurring on the ORR that are federally listed as endangered or threatened, candidate species for federal listing, listed by the State of Tennessee, or are of special concern (considered at risk) based on other sources. Additionally, the surveys allow the identification of potential habitat for such species on the ORR and the identification of potential threats to such species on the ORR.

Data collected during these surveys aids in Comprehensive Environmental Response, Compensation, and Liability Act (CERCLA) remedial investigations on the ORR. The surveys also provide data for EM decision documents, ensure that remedial decisions have legal defensibility, provide a baseline for ensuring compliance with principal legal requirements [including ESA, NEPA, CERCLA, National Resource Damage Assessments (NRDA), and the Clean Water Act (CWA)] and will increase public confidence in DOE's adherence to all related environmental resources rules, laws, regulations, and instructions. 


\section{METHODS}

The ORR T\&E plant survey project can be broken down into three primary tasks: compilation of existing data, field surveys, and documentation.

\subsection{COMPILATION OF PRE-EXISTING DATA}

Data existing prior to the initiation of this project was compiled and published during Fall 1993 (Cunningham et al. 1993; Pounds, Parr, and Ryan 1993). Updated state and federal rare plant lists were obtained from TDEC and the Federal Register. Data from previous plant surveys on the ORR were reviewed and evaluated for completeness. A preliminary map of areas for which rare plant data was available and was prepared using geographic information systems (GIS); this coverage was then overlaid onto the EM waste areas map to determine the availability of rare plant data for the waste areas. The following data sets were compiled:

- Vascular plants documented to occur on the ORR

- T\&E vascular plant species not documented from the ORR but known to exist in areas near the ORR

- T\&E vascular plant species occurring in the Ridge and Valley Physiographic Province of Tennessee which potentially occur in habitat types found on the ORR

- Characterization data for T\&E vascular plant species occurring on the ORR, near the ORR, or potentially within habitats present on the ORR (i.e., range information; habitat requirements; life cycle characteristics such as dates of emergence, flowering, and setting of fruit or seed; and distinguishing morphologic features)

- Descriptions of environmentally sensitive areas on the ORR known to contain rare plants or rare communities

- Landscape elements frequently associated with rare species on the ORR (landscape elements are land types and formations which provide the underlying structure for the development of biological habitats and communities; many T\&E species are associated with or restricted to certain land types/formations)

\subsection{FIELD SURVEYS}

Field surveys were conducted to locate and identify T\&E plant species and sensitive habitats on the ground. Areas of the ORR lacking sufficient information concerning rare plants and sensitive habitats were ranked for urgency of field surveys and selected for site visits in a roughly descending order based on the following priorities: (1) EM waste areas, (2) areas where projects have been proposed, (3) areas most likely to be impacted in the near future, (4) areas containing landscape elements and natural communities associated with T\&E species, (5) remaining areas of the ORR. In addition, selected areas with known rare plant populations were visited to collect baseline data on those populations. 
Field surveys were conducted by trained biologists familiar with the regional flora who have familiarized themselves with the distinguishing morphologic characteristics, life cycles, and habitats of the rare plant species occurring or potentially occurring in the area investigated. Field surveys sometimes required multiple site visits when taxonomic identifications required plant parts available during other seasons ("seasonal identification") when environmental conditions were unfavorable for the growth and/or observation of a species during the initial visit or when population monitoring efforts were undertaken. Types of records produced in the course of field surveys included species lists, data sheets, maps, photos, herbarium specimens, and written reports. The following types of methods were applied in the course of field surveys and are presented in order of decreasing areal scale and increasing level of detail of data provided: exploration, systematic search, and population monitoring.

\subsubsection{Exploration}

Exploration is the least costly and labor intensive survey method, and is generally applied over areas on a scale of 10-1000 acres. In an exploration, landscape features frequently associated with T\&E species present on the ORR are sought out and identified during the site visit, and ground coverage is skewed towards those areas most likely to yield important results. Sensitive landscape elements potentially associated with T\&E species on the ORR include wetlands, springs and seeps, barrens, steep slopes, rock outcrops, sinkholes, cliffs, streams, and large unfragmented native forest tracts. In addition, some artificial habitats may be associated with T\&E species: in particular, unusual disturbances, anthropogenic impoundments, and areas where woody growth is suppressed but natural vegetation dominates, such as under power lines.

\subsubsection{Systematic Search}

A systematic search is the method of choice when intensive disturbance is planned for a specific site, and increased documentation is required for legal purposes. A systematic search is generally applied over a scale of 1-10 acres. During a systematic search, the entire area is walked and searched for T\&E plant species in a pattern of transects. This allows a more complete visual coverage of the site, taking into account topographic features (such as hills and obstacles) and existing sight range limiting conditions (such as light level, fog, and vegetation density). The surveyor develops and maintains mental search images of the potential T\&E species occurring on the ORR by visiting sites where they have been found and by viewing photographs prior to the search. The surveyor also must maintain an alertness to unusual conditions or features which may signal the presence of a T\&E species.

\subsubsection{Population Monitoring}

Population monitoring is used to provide detailed baseline population data for selected rare species. Monitoring is generally applied on a scale of less than 1 acre to 2 acres. The level of detail involved in a monitoring effort ranges from simply checking for the continued existence and reproduction of a species at a site to population estimates, direct population counts, or determination of age, size, and /or sexual structure of the population. In addition, ancillary information about the site, such as topographic position, slope, aspect, light conditions, moisture levels, disturbances, and presence of pollinators, may also be collected. 


\subsection{DOCUMENTATION}

Documentation of vascular plant species occurring on the ORR was accomplished by combining specimens, photography, and the ORR vascular flora data base. Taxonomic identification of vascular plant species was performed using appropriate regional guides (Radford et al. 1968, Wofford 1989, Croniquist 1980, Kral 1983, Massey et al. 1983, Gleason 1952, Gleason and Cronquist 1991). Difficult to identify specimens and specimens which potentially represented T\&E species were then referred to appropriate taxonomic experts at the University of Tennessee (UT), the Tennessee State Heritage Program, and other universities, herbaria, and museums for identification. Voucher specimens were collected as physical documentation for vascular plant species when removal of the specimen was not deemed to jeopardize the population. When collection

of a voucher specimen was deemed unacceptable, a photograph was taken in its place. Voucher specimens were collected for both listed and nonlisted vascular plant species occurring on the ORR. Baseline documentation for currently non-T\&E species as well as $T \& E$ species were provided, since species may be added to federal and state lists in the future. Voucher specimens were mounted on nonacidic herbarium paper, labeled with the location found, the collector's name, and the collection date, and then filed in the ORR herbarium. Species which were not vouchered through removal of a physical specimen were instead vouchered by mounting and filing a photograph of the specimen taken on-location. In addition, all T\&E species were photographed on location. Photographs were supplied with ORNL Photography Department numbers, and the negatives are maintained by the ORNL Photography Department. All vascular plant species identified from the ORR were entered into the ORR vascular flora data base, along with supporting information. An explanation of the data contained in the ORR vascular flora data base, along with a printout of the data base, is provided in Appendix A.

Documentation of surveys and field sample sites for T\&E species, their habitats, and associated sensitive landscape elements was accomplished through mapping using a GIS. Environmentally sensitive areas on the ORR are delineated by combining data from multiple sources to identify the extents of sensitive species, their habitats, and necessary buffer zones. Spatial data is input into the GIS through digitizing and/or use of global positioning systems. Mapped coverages of T\&E plant species and sensitive habitat locations are being provided to the Oak Ridge Environmental Information System (OREIS). Access to some kinds of information (e.g., actual locations of T\&E species) will be restricted. 


\section{RESULTS}

\subsection{SURVEY COVERAGE}

During 1991-1994, approximately 12,000 acres of the ORR were surveyed for T\&E vascular plants (Figure 1); summary data for 1992-1994 is presented in Table 1. During 1995 and 1996, field surveys for T\&E vascular plants were conducted on approximately 2,000 acres of the ORR (Figs. 1, 2). Field survey data for 1995-1996 is presented in Table 2. Approximately 14,000 acres of the ORR have been surveyed for T\&E vascular plants as of May 1996. Approximately 21,000 acres of the ORR have not been surveyed for T\&E vascular plant species; survey coverage gaps are shown in fig. 3.

\subsection{T\&E SPECIES ON THE ORR}

Of the 28 listed vascular plant species identified on the ORR to date (Table 3), 18 were reported prior to 1993 (Cunningham et al. 1993, Pounds 1993), and an additional 10 were reported between 1993 and 1996. Fig. 4 shows identified point occurrences for T\&E vascular plant species on the ORR based on field survey sample sites (this data should not be interpreted as indicating the areal extent of these species). T\&E vascular plant species have been identified from a total of 267 sites on the ORR to date. T\&E vascular plant sites identified at existing sources and field surveys prior to 1995 total 82 . An additional $185 \mathrm{~T} \& \mathrm{E}$ vascular plant sites were identified as a result of field surveys conducted during 1995 through May 1996.

Specific locations of rare plants on the ORR are kept on file by the Oak Ridge National Laboratory (ORNL) area manager. The occurrence of T\&E species within operable units (OUs) and waste area groupings (WAGs), environmentally sensitive areas, and other areas on the ORR, is presented in Table 4. Environmentally sensitive areas, including the extent of T\&E plant species as currently known, their habitats, and necessary buffer zones, are shown in Fig. 5. Occurrence sites (Fig. 4) and ranges, associated rare natural communities (TNC 1995, Grossman et al. 1994), environmentally sensitive landscape elements, and appropriate buffer zones based on local topography were used to delineate environmentally sensitive areas.

\subsubsection{Federal T\&E Species}

No federally listed vascular plant species have been found on the ORR during this survey. Four vascular plant species reported from the ORR are of "special concern" at the federal level because not enough information is currently available to determine their status; these four species were listed on the formerly used $\mathrm{C} 2$ federal candidate list [Aureolaria patula, Cimicifuga rubifolia, Delphinium exaltatum, Juglans cinerea (Table 3)]. Juglans cinerea has been attacked by butternut canker throughout its range; identifiable (mature) growth of Juglans cinerea was not found on the ORR during this survey although rootstocks and sprouts which may represent this species are present.

\subsubsection{Tennessee T\&E Species}

Twenty-eight vascular plant species that have been listed by the state of Tennessee have been reported as occurring within the current ORR boundaries to date; these species are listed in Table 3 along with their status. Two of the species, Lilium michiganense and Carex oxylepis var. 
pubescens have been identified from the ORR in the past but were not found during this survey. Lilium michiganense may have been extirpated from the ORR by the impoundment at Melton Hill dam. Also included in Table 3 is a nonlisted vascular plant species found on the ORR, Collinsonia verticillata, which is ranked highly by The Nature Conservancy (TNC) and may be a potential candidate for listing in Tennessee.

\subsubsection{Other T\&E Species Which May Be Present on the ORR}

The following vascular plant species listed by the state of Tennessee were reported from sites which are no longer part of the ORR: Agalinis auriculata (also listed under the formerly used federal C2 candidate designation), Gnaphalium helleri, Liatris cylindracea, and Solidago ptarmicoides. These species may be present within the current ORR boundaries but were not found during this survey. Other listed vascular plant species deemed as potentially occurring on the ORR (occurring near the ORR and/or occurring in habitat found on the ORR) which may be present on the ORR but were not found during this survey are listed in Table 5.

\subsection{VOUCHERS}

Over 1,100 species of vascular plants have been identified on the ORR to date (Appendix A). Approximately 983 of these species were recorded prior to 1993 (Cunningham et al. 1993). An additional 144 species were recorded and vouchered (specimens placed in the ORR herbarium)as a result of field surveys during 1992-1996 (Table 6). Other institutional herbariums (in addition to the ORNL herbarium) that maintain vascular plant voucher specimens from the ORR are listed in Appendix A. Voucher photographs of Tennessee state-listed and federal "special concern" vascular plant species and their habitats on the ORR are filed with the ORNL Photography Department. A list of voucher photographs and their ORNL Photography Department numbers is provided in Table 7.

\subsection{CHARACTERIZATION ABSTRACTS}

Information for the following species characterization abstracts was taken from the following sources: Radford et al. 1968, Wofford 1989, Cronquist 1980, Kral 1983, Massey et al. 1983, Gleason 1952, Gleason and Cronquist 1991, Pyne and Shea 1994a,b,c. Range information was compiled from these sources and Chester et al. (1993). A discussion by TNC (1995) of the conservation significance of ORR populations of rare plants has been quoted in the abstracts when available. Table 8 provides abbreviations for U.S. states used in these abstracts.

\subsubsection{T\&E Vascular Plant Species Found on the ORR}

\subsubsection{Aureolaria patula (Chapm.) Pennell}

Common name: Spreading false-foxglove

Family: Scrophulariaceae

Federal status: Special Concern (listed under the formerly used C2 candidate designation) 
Tennessee status: Threatened

Location on ORR: Bethel Valley groundwater operable unit (GWOU), K-25 GWOU, Melton Valley GWOU, NA1, NA3, NA6, NA14, NA16, NA17, NA19, NA20, NA30, NA32, NA33, NA37, NA45

Habitat: Wooded, calcareous, river and creek bluffs (Kral 1983)

Habitat on ORR: In shade on calcareous bluffs and talus slopes along the Clinch River and several tributaries (often at the edge of a lake or large stream)

Range: Central KY to north GA and $\mathrm{AL}$

Tennessee counties: Anderson, Coffee, Knox, Morgan, and Roane

Description: Erect to decumbent perennial herb with stems up to $12 \mathrm{dm}$ in length. Stem not glaucus somewhat hairy. Lower leaves lobed. Corolla yellow, pedicels 15 to $25 \mathrm{~mm}$ long, capsule glabrous

Similar species:

1. Aureolaria virginica has short pedicels (1-3 mm)

2. Aureolaria laevigata and $A$. flava lack hairs

Flowering date: Late July through early October

Fruiting date: October-November

Comments: Other rare or uncommon species co-occurring with $A$. patula on the ORR are Cimicifuga rubifolia, Diervilla lonicera, Thuja occidentalis, and a mat-forming variant of Blephilia ciliata

Threats on ORR: Habitat destruction, excessive reservoir water level fluctuations, recreational activity on river banks, and tree canopy removal. Overgrowth by kudzu, an aggressive exotic vine, threatens at least one population.

TNC ORR conservation significance: "A number of populations of this species occur on ORR. Many of these sites adjoin the Clinch River, and often occur near the water's edge. It is possible that it is being dispersed by water. Spreading false-foxglove has a small range, and is rare and scattered within it. All remaining viable populations are important to its survival."

\subsubsection{Carex gravida Bailey}

Common name: Heavy sedge

Family: Cyperaceae

Federal status: None

Tennessee status: Special Concern 
Location on ORR: Bethel Valley GWOU, K-25 GWOU, Melton Valley GWOU, NA 32, NA 42, NA51

Habitat: Dry, open areas

Habitat on ORR: Wooded, rocky slopes

Range: Southeast MI, south IA, and KS; south to TX and further east (TN, NC) perhaps as a recent introduction

Tennessee counties: Knox, Meigs, Montgomery, and Roane

Description: An inconspicuous sedge. Difficult to identify in the field below genus level. Expert consultation is required for positive identification. May sometimes be detected in the field by noting that the fruiting culms are leaning over close to the ground and thus the common name but other Carex species may do this also.

Fruiting date: Summer

Comments: C. gravida is growing in surprisingly shady and undisturbed locations on the ORR. Radford et al. (1968) describe the species habitat in the Carolinas as waste places.

Threats on ORR: Habitat destruction

TNC ORR conservation significance: "The populations on the ORR are at the eastern limit of this primarily midwestern species. Populations peripheral to the main range of a species often indicate unusual habitats and represent unique genetic material."

\subsubsection{Carex howei Mack (Carex atlantica L.H. Bailey var. capillacea}

(L.H. BAILEY) Reznicek)

Common name: Howe's Sedge

Family: Cyperacae

Federal status: None

Tennessee status: Endangered

Location on ORR: NA55

Habitat: Shaded wetlands

Habitat on ORR: Shaded wetlands

Range: Mainly on the coastal plain but occasionally inland to $\mathrm{OH}$, southern Ontario, southern $\mathrm{MI}$, and northern $\mathrm{N}$

Tennessee counties: Hardeman, Chester, Hardin, Lewis, Hickman, Maury, Putnam, White, Roane 
(ORR), Cocke[ Great Smoky Mountains National Park (GSMNP)]

Description: culms $2.5-5.5 \mathrm{dm}$ tall, blades usually about $1 \mathrm{~mm}$ (less than $1.3 \mathrm{~mm}$ ), perigynia spreading, staminate flowers mostly at the base of the terminal spike

Similar species:

1. Carex interior differs in having no nerves on the perigynia (rarely a few) while C. howei has several.

2. Carex incomperta (Carex atlantica var. atlantica) differs in having blades $1.5-4 \mathrm{~mm}$ rather than less than $1.3 \mathrm{~mm}$

Flowering date: May-June

Threats on ORR: This species could be negatively effected by canopy opening, change in hydrological regime and/or siltation

TNC ORR conservation significance: This species was discovered on the ORR after TNC report

3.4.1.4 Carex oxylepis Torr. \& Hook. var. pubescens J.K. Underw.

Common name: Hairy sharp-scaled sedge

Family: Cyperaceae

Federal status: None

Tennessee status: Special Concern

Location on ORR: Melton Valley GWOU, WAG 2, CMA 5

Habitat: Shaded wetland

Habitat on ORR: Shaded wetland.

Range: Southeastern VA to northern FL, west to east and southeastern TX, northward in the interior to $\mathrm{OK}, \mathrm{AK}, \mathrm{MO}, \mathrm{TN}$

Tennessee counties: Cheatham, Davidson, Perry, Roane, Rutherford

Description: A sedge similar to the more common Carex debilis. Expert consultation is required for positive identification.

Fruiting date: Late spring and summer

Comments: Carex expert V. McNeilis (UT herbarium) does not consider this to be a valid taxon, but it is recognized by TDEC. The only specimen of this variety taken from the ORR is in the Smithsonian Institute herbarium (Washington, D.C.). The other variety of the species (Carex oxylepis var. oxylepis) has been collected several times on the ORR. 
Threats on ORR: Habitat destruction and habitat invasion by Microstegium vimineum

TNC ORR conservation significance: "The current status of this variety at ORR is uncertain; it has not been seen in recent years."

\subsubsection{Cimicifuga rubifolia Kearney}

Common name: Appalachian bugbane

Family: Ranunculaceae

Federal status: Special Concern (was listed under the formerly used C2 candidate designation)

Tennessee status: Threatened

Location on ORR: NA1, NA3, NA11, NA 15, NA19, NA23

Habitat: Wooded bluffs, ravines, coves, north-facing talus slopes; prefers limestone or calcareous shale (Massey et al. 1983)

Habitat on ORR: Wooded talus slopes along Clinch River and Grassy Creek, a tributary of Clinch River

Range: $\mathrm{AL}, \mathrm{IL}, \mathrm{IN}, \mathrm{KY}, \mathrm{NC}, \mathrm{PA}, \mathrm{TN}$, and VA

Tennessee counties: Anderson, Claiborne, Grainger, Hamblin, Hancock, Hawkins, Jefferson, Knox, Loudon, Meigs, Montgomery, Roane, Stewart, and Sullivan

Description: Perennial herb with mostly basal, compound leaves of three to nine leaflets. Base of terminal leaflet is deeply cordate. Solitary, wand-like flowering stem up to $14 \mathrm{dm}$ tall. Flowers are white.

Similar species:

1. Astilbe biternatum is vegatatively very similar and grows in the same habitat. It is useful to look for old flowering stalks to aid the identification.

2. Other Cimicifuga have 15 or more leaflets per leaf while C. rubifolia normally has 3-9.

Flowering date: July-October

Fruiting date: September-October

Comments: Other rare species co-occurring with C. rubifolia on the ORR are Saxifraga careyana, Diervilla lonicera, and Aureolaria patula.

Threats on ORR: Habitat destruction, tree canopy removal, invasion of habitat by competing exotic species (which may result from forest fragmentation)

TNC ORR conservation significance: "This species is scarce throughout its narrow range. 
Important populations of this species occur on ORR."

3.4.1.6 Collinsonia verticillata Baldwin ex Elliot

Common name: Whorled horse-balm

Family: Lamiaceae

Federal status: None

Tennessee status: None

Location on ORR: BCOU4, K-25 GWOU, Melton Valley GWOU, NA39, NA41, NA44, NA45, NA52, NA54

Habitat: Wooded slopes.

Habitat on ORR: Mature mesic forest.

Range: AL, GA, NC, SC, TN, VA (disjunct), $\mathrm{OH}$ (disjunct).

Tennessee counties: Blount, Cumberland, Hamilton, Knox, McMinn, Meigs, Rhea, Roane, Sevier, possibly Anderson

Description: Perennial herb (2-8 dm) with upper leaves appearing whorled. Flowers are lavender, light pink, or white.

Similar species:

1. Collinsonia canadensis might be confused with $C$. verticillata when flowers are absent, but usually the leaves do not appear whorled on Collinsonia canadensis.

Flowering date: Late April through early June

Fruiting date: June-July

Comments: Highly ranked by TNC

Threats on ORR: Habitat loss

TNC ORR conservation significance: Not described in the ORR report

\subsubsection{Cypripedium acaule Ait.}

Common name: Pink lady-slipper

Family: Orchidaceae

Federal status: None

Tennessee status: Endangered (due to commercial exploitation) 
Location on ORR: BCOU4, Bethel Valley GWOU, Melton Valley GWOU, HA2, HA4, HA7, NA4, NA6, NA14, NA20, NA24, NA25, NA42, NA46, NA47, RA 6, RA9

Habitat: Bogs and dry, acid pine woods (Radford et al. 1968)

Habitat on ORR: Moist to dry acid woods with pine trees

Range: East US; south to SC and AL

Tennessee counties: Perhaps in all counties of East Tennessee, but not found west of the eastern Highland Rim

Description: Two large, ribbed ovate leaves are at the base of a single flowered scape. Flower pink, fissured in front

Similar species: Cypripedium acaule is rarely white flowered, possibly leading to confusion, but the pair of large basal leaves is unique among our Cypripedium.

Flowering date: April-July

Comments: C. acaule is a showy species much prized in the wildflower trade. Evidence to date indicates that not only is the species being removed from its habitat in large numbers across the state, but also, no propagation techniques are known to be successful. For this reason, TDEC lists the species as endangered in Tennessee.

Threats on ORR: Habitat loss, tree canopy removal, and illegal digging

TNC ORR conservation significance: "The significance of ORR populations of this widespread and common species is minor. It grows in several ORR locations, mostly in moist to dry acidic woods, especially in successional pine forests. Occurrences on ORR are more protected from collection (one of the main threats to the species) than populations on private or unrestricted public land."

\subsubsection{Delphinium exaltatum Ait.}

Common name: Tall larkspur

Family: Ranunculaceae

Federal status: Special Concern (listed under the formerly used C2 candidate designation)

Tennessee status: Endangered

Location on ORR: Bethel Valley GWOU, NA7, NA8, NA35, NA36, NA43

Habitat: Rich, moist, loamy soils of open, calcareous, wooded ravines (Kral 1976)

Habitat on ORR: Open, rocky, calcareous woods, barrens, and utility right of ways 
Range: IN, MO, NC, OH, PA, TN, VA, WV, IA, and ME

Tennessee counties: Anderson, Hamilton, and Roane

Description: Erect, solitary stems to $15 \mathrm{dm}$ in height. Branched racemes with blue flowers late in season

Similar species:

1. Aconitum uncinatum in the early stages (basal leaves) before the stem develops is very similar and should be differentiated at a later stage.

2. Other species of Delphinium which might be confused with $D$. exaltatum are hairy on the stem below the inflorescence.

Flowering date: August-September

Fruiting date: September-October

Threats on ORR: Habitat destruction, invasion of habitat by woody species, shade, fire suppression

TNC ORR conservation significance: "One of the largest range-wide populations of this species occurs on ORR. Several additional populations are also important to this species' survival."

\subsubsection{Diervilla lonicera P. Mill.}

Common name: Northern bush-honeysuckle

Family: Caprifoliaceae

Federal status: None

Tennessee status: Threatened

Location on ORR: NA11, NA14

Habitat: Woodlands and rocky bluffs (Radford et al. 1968)

Habitat on ORR: Calcareous, rocky bluffs along the Clinch River

Range: AL, CT, DE, GA, IA, IL, IN, KS, MA, ME, MI, MN, NC, NH, NY, OH, PA, SC, TN, VA, VT, WI, and WV

Tennessee counties: Anderson, Cheatham, Polk, and Sevier

Description: Deciduous shrub to $20 \mathrm{dm}$ tall. Simple, opposite, lanceolate leaves. Light-yellow flowers resembling honeysuckle that turn red with age

Similar species:

1. Shrubby honeysuckles (Lonicera) do not have teeth on the leaves. 
2. Diervilla sessilifolia has sessile leaves.

Flowering date: June-July

Fruiting date: August-October

Comments: Other rare or uncommon species co-occurring with $D$. lonicera on the ORR are Thuja occidentalis, Cimicifuga rubilfolia, and Aureolaria patula.

Threats on ORR: Habitat destruction.

TNC ORR conservation significance: "Populations on ORR and nearby represent a somewhat disjunct concentration of populations of this northern shrub. Populations peripheral to the main range of a species often indicate unusual habitats and represent unique genetic material."

\subsubsection{Draba ramosissima Desv.}

Common name: Branching whitlow-grass

Family: Brassicaceae

Federal status: None

Tennessee status: Special Concern

Location on ORR: K-25 GWOU, NA37

Habitat: Dry, usually calcareous bluffs (Wofford 1989)

Habitat on ORR: Dry limestone ledges along Watts Bar Lake

Range: VA, WV, eastern $\mathrm{KY}, \mathrm{NC}$, and $\mathrm{TN}$

Tennessee counties: Anderson, Blount, DeKalb, Hancock, Polk, Putnam and Roane

Description: Mat-forming perennial. Basal rosettes with oblanceolate, toothed leaves. Petals entire, style persistent, and fruit twisted. Flowering stems $(1-4 \mathrm{dm})$. Flowers are white.

Flowering date: April-May

Fruiting date: May-July

Threats on ORR: Habitat destruction, habitat invasion by competing exotic species following forest fragmentation

TNC ORR conservation significance: "This species is very rare in Tennessee and has only a narrow distribution in the Central and Southern Appalachians." 


\subsubsection{Elodea nuttallii (Planch.) St. John}

Common name: Nuttall waterweed

Family: Hydrocharitaceae

Federal status: None

Tennessee status: Special Concern

Location on ORR: Bethel Valley GWOU, Melton Valley GWOU, NA6, NA47, RA28

Habitat: Lakes, ponds, and sluggish streams (Radford et al. 1968)

Habitat on ORR: Clinch River embayment, ponds

Range: MA to VA; west to MN, MO, and OR; now known from TN and NC

Tennessee counties: Lake, Montgomery, Obion, and Roane

Description: Submerged aquatic with whorls of three leaves. Leaves are linear, acute, and densely imbricate at growing tips. The miniscule staminate flowers are free floating, sometimes appearing as a white powder on the surface of the water.

Similar species:

1. Elodea canadensis does not have the free floating flowers

Flowering date: July-September

Comments: No other rare species are known to co-occur with $E$. nuttallii on the ORR. Probably a recent introduction

Threats on ORR: Habitat destruction, draining of ponds, water temperature change, water pollution

TNC ORR conservation significance: "Nuttall's waterweed has established itself at ORR in artificial ponds or embayments of the Clinch River. It may be dispersed by waterfowl. The ORR lies at the edge of the range of this species. Populations peripheral to the main range of a species often indicate unusual habitats and represent unique genetic material."

\subsubsection{Fothergilla major (Sims) Lodd.}

Common name: Mountain witch-alder

Family: Hamamelidaceae

Federal status: None

Tennessee status: Threatened

Location on ORR: NA12 
Habitat: Rocky woodlands (Wofford 1989)

Habitat on ORR: On west-facing slope in woods

Range: $A L, A R, G A, N C, S C$, and $T N$

Tennessee counties: Anderson, Grainger, Greene, Scott, and Sevier

Description: Stoloniferous shrub or small tree. Alternately arranged, deciduous leaves are pinnately veined. Flowers are white and epetalate and occur in terminal spikes.

Similar species:

1. Hamamelis virginica is similar when flowers and fruit are absent but lacks stellate hairs on the undersides of the leaves

Flowering date: April-May

Fruiting date: July

Comments: No other listed species are known to occur with $F$. major on the ORR

Threats on ORR: Habitat destruction, severe fire, and tree canopy removal

TNC ORR conservation significance: "Currently known from a single site on ORR, Mountain Witch-alder is rare and scattered throughout its range. In Tennessee, it is primarily in the Blue Ridge province, and its occurrence on ORR is somewhat isolated. Populations peripheral to the main range of a species often indicate unusual habitats and represent unique genetic material."

\subsubsection{Hydrastis canadensis $\mathrm{L}$.}

Common name: Golden seal

Family: Ranunculaceae

Federal status: None (was listed under the formerly used $3 \mathrm{C}$ category)

Tennessee status: Threatened

Location on ORR: NA2, NA6, NA10, NA21, NA47, NA52, RA8

Habitat: Rich woods (Radford et al. 1968)

Habitat on ORR: Rich, moist woods

Range: AL, AR, CT, DE, GA, IA, IL, IN, KY, MA, MI, MN, MO, MS, NC, NY, OH, PA, TN, VA, VT, WI, and WV

Tennessee counties: Anderson, Blount, Campbell, Cannon, Carter, Clay, Coffee, Cumberland, Davidson, DeKalb, Fentress, Franklin, Grundy, Hancock, Hardin, Jackson, Knox, Loudon, Marion, 
Montgomery, Morgan, Obion, Putnam, Rhea, Roane, Scott, Shelby, Stewart, Sullivan, Sumner, Tipton, Van Buren, Warren, Wayne, and White

Description: Erect, perennial herb with thick yellow rhizomes. Stems $1.5-5 \mathrm{dm}$ tall. Solitary, greenish-white, epetalate flowers with numerous stamens

Similar species: None

Flowering date: April to May

Fruiting date: June-July

Comments: Hydrastis canadensis is a valued medicinal herb on both national and international markets. Like ginseng, its rarity is primarily the result of herb collectors digging the plants. Other rare species that co-occur with $H$. canadensis on the ORR are Spiranthes ovalis and Lilium canadense.

Threats on ORR: Habitat destruction, unauthorized digging to remove plants, tree canopy removal, invasion of habitat by competing exotic species following forest fragmentation, erosion and siltation related to upslope timber salvage activities

TNC ORR conservation significance: "ORR populations are more protected from collection pressures (one of the main threats to the species) than populations on private or unrestricted public land. The importance of these populations needs further assessment."

\subsubsection{Juglans cinerea L.}

Common name: Butternut, white walnut

Family: Juglandaceae

Federal status: Special Concern (was listed under formerly used C2 candidate designation)

Tennessee status: Threatened

Location on ORR: Melton Valley GWOU, WAG 2, NA32 (These specimens are most likely Juglans cinerea $\mathrm{L}_{\text {, }}$, but they cannot be confirmed because of immature specimen growth.)

Habitat: Rich woods

Habitat on ORR: Slopes near major streams

Range: New Brunswick to Ontario; south to MI and ND; south to VA, GA, AR, and KS

Tennessee counties: Anderson, Blount, Campbell, Carter, Chester, Cooke, Cumberland, Franklin, Hamilton, Hawkins, Hickman, Houston, Lewis, Monroe, Polk, Roane, Sevier, Stewart, Sumner, Tipton, Van Buren, Wayne, and Williamson

Description: A walnut tree that can be distinguished from the common black walnut by its 
elongated fruit (ellipsoidal vs. spherical) and smoother bark. Pith color and hairiness above the leaf scar characteristics appear to be difficult to apply.

Similar species: see "Description" and "Comments"

Flowering date: April-May

Fruiting date: October

Comments: Butternut was previously listed under formerly used C2 candidate designation by the U. S. Fish and Wildlife Service (USFWS) because of the threat of a fatal disease- butternut canker. We have observed no nut production in butternut on the ORR. The identification of walnut species at two locations is in question. The identification of these young trees was based on pith color, which may not be reliable. The ORR herbarium has a specimen from 1965 . M. W. Bierner verified the identification in 1974. There is a possibility that Manchurian walnut has been introduced on the ORR. It could be confused with the other two species of walnut.

Threats on ORR: Habitat destruction, cutting

TNC ORR conservation significance: "The importance and health of these populations needs additional assessment. Reproducing populations are extremely rare."

\subsubsection{Juncus brachycephalus (Engelm.) Buchenau}

Common name: Small-head rush

Family: Juncaceae

Federal status: None

Tennessee status: Special Concern

Location on ORR: Bethel Valley GWOU, NA24, NA38

Habitat: Fens

Habitat on ORR: Open wetlands

Range: ME to northern Ontario and WI, south to PA, OH, and IN. Disjunct in TN.

Tennessee counties: Cheatham, Claiborne, Humphrey, Lewis, Maury, Roane, Warren, Wayne

Description: Rushes are grass-like plants. This species bears mature fruits after the other rushes on the ORR

Fruiting date: Late July, Aug., possibly Sept.

Threats on ORR: Habitat destruction from project development, hydrologic regime change, and at one site, possible disturbance related to the adjacent highway 
TNC ORR conservation significance: "This species is very rare in Tennessee. The ORR population is one of very few known in the Ridge and Valley Province of Tennessee. Populations peripheral to the main range of a species often indicate unusual habitats and represent unique genetic material."

\subsubsection{Lilium canadense $\mathbf{L}$.}

Common name: Canada lily

Family: Liliaceae

Federal status: None

Tennessee status: Threatened

Location on ORR: BCOU4, Bethel Valley GWOU, Melton Valley GWOU, NA2, NA8, NA13. NA22, NA25, NA26, NA29, NA31, NA34, NA35, NA36, NA42, NA50, NA56

Habitat: Wet meadows, bogs, and balds (Radford et al. 1968)

Habitat on ORR: Moist woods, forest edges, and power line openings through moist forest

Range: Quebec and ME to MN; AL, CT, DE, DC, IA, IN, KS, KY, MA, ME, MI, MO, NE, NH, NY, OH, OK, PA, RI, SC, SD, TN, VT, VA, WV, and WI

Tennessee counties: Anderson, Campbell, Claiborne, Cumberland, Davidson, DeKalb, Johnson, Montgomery, Morgan, Overton, Putnam, Roane, Rutherford, Scott, Sevier, and Stewart

Description: Stems to $20 \mathrm{dm}$ tall with whorls of 5-11 leaves. Flower segments are yellow-orange to red, spotted, and slightly recurred to spreading. Petals and sepals more than $6 \mathrm{~cm}$ long

\section{Similar species:}

1. Lilium michiganense is very similar but can be distinguished when in bloom. Lilium canadense has anthers held close together, barely, or not at all exerted from the only slightly or moderately recurved tepals rather than anthers well separated on strongly divergent filaments with the tepals strongly recurved-reflexed.

2. Lilium superbum has smooth leaf margins rather than spiculate-scabrous.

Flowering date: June-July

Fruiting date: July-September

Comments: This species is very similar vegetatively to and may be confused with Lilium michiganense, which is also a Tennessee state-listed threatened species. These native lilies rarely bloom on the ORR. It is possible that the populations which have not been seen to flower include Lilium michiganense.

Threats on ORR: Digging up for transplanting, habitat destruction, indiscriminate use of herbicides, fire supression 
TNC ORR conservation significance: "Occurrences on ORR are more protected from collection (one of the main threats to the species) than populations on private or unrestricted public land. Wetlands in the Ridge and Valley Province are rare and often in poor condition, while those on the ORR are in better condition. Populations peripheral to the main range of a species often indicate unusual habitats and represent unique genetic material."

\subsubsection{Lilium michiganense Farw.}

Common name: Michigan lily

Family: Liliaceae

Federal status: None

Tennessee status: Threatened

Location on ORR: Not currenty known to exist on the ORR. See "Threats on ORR" below.

Habitat: Wetlands

Habitat on ORR: Wetlands

Range:Western NY and southern Ontario to Manitoba, south to TN and AL

Tennessee counties: Shelby, Lewis, Steward, Montgomery, Dickson, Davidson, White, Warren, Van Buren, Bledsoe, Coffee, Grundy, Sequatchie, Anderson

Description: Stems to $20 \mathrm{dm}$ tall with whorls of 5-11 leaves. Flower segments are yellow-orange to red, spotted, and slightly recurred to spreading. Petals and sepals more than $6 \mathrm{~cm}$ long.

Similar species:

1. Lilium superbum has smooth leaf margins rather than spiculate-scabrous.

2. Lilium canadense has anthers held close together, barely, or not at all exerted from the only slightly or moderately recurved tepals rather than anthers well separated on strongly divergent filaments with the tepals strongly recurved-reflexed.

Flowering date: June-July

Fruiting date: Late summer

Threats on ORR:. Digging up for transplanting, habitat destruction, indiscriminate use of herbicides, fire suppression. May have been extirpated from the ORR by the impoundment at Melton Hill Dam.

TNC ORR conservation significance: This species was not described in the ORR report

\subsubsection{Liparis loeselii (L.) L. C. Rich}

Common name: Fen orchid 
Family: Orchidaceae

Federal status: None

Tennessee status: Endangered

Location on ORR: NA24

Habitat: Cool ravines and moist seepage slopes (Radford et al. 1968)

Habitat on ORR: Wetland in immature forest with wetland shrubs overstory

Range: Nova Scotia and Quebec to Manitoba; south to NJ, AL, OH, IN, and NE

Tennessee counties: DeKalb, Carter, Unicoi, and Roane

Description: Scapose herb with two basal leaves. Stem slender, 6-26 cm tall. Flowers yellowish-green to white. Pedicels 3-6 mm long.

Similar species: 1 . Liparis liliifolia has purple flowers

Flowering date: May-July

Fruiting date: July-August

Comments: L. loeselli typically does not occur at low elevations as far south as the ORR

Threats on ORR: Habitat destruction, change in hydrologic regime (drainage or flooding), and tree canopy removal

TNC ORR conservation significance: "This species has fewer than ten occurrences statewide. It grows in ORR wetlands sheltered by immature woods. Wetlands in the Ridge and Valley province are rare and often in poor condition, while those on the ORR are in better condition."

\subsubsection{Panax quinquifolius L.}

\section{Common name: Ginseng}

Family: Araliaceae

Federal status: None (was listed under the formerly used $3 C$ candidate category)

Tennessee status: Threatened

Location on ORR: BCOU4, Bethel Valley GWOU, Melton Valley GWOU, HA1, HA3, HA5, HA6, NA4, NA6, NA11, NA12, NA36, NA44, NA47, NA51, NA52, NA54, NA56, RA14

Habitat: Rich woods (Radford et al. 1968) 
Habitat on ORR: Rich, moist to dry woods

Range: AL, AR, CT, DE, GA, IA, IL, IN, KY, LA, MA, ME, MI, MN, MO, MS, NC, NE, NH, NJ, $\mathrm{NY}, \mathrm{OH}, \mathrm{OK}, \mathrm{PA}, \mathrm{SC}, \mathrm{SD}, \mathrm{TN}, \mathrm{VA}, \mathrm{VT}, \mathrm{WI}$, and WV

Tennessee counties: Virtually all counties

Description: Glabrous, perennial herb arising from tuberous roots. Stems erect, $1.5-6 \mathrm{dm}$ tall. Petiolate, palmately compound leaves in a whorl at apex of the solitary stem

Flowering date: May-June

Fruiting date: August-October

Comments: Ginseng is prized in this country and abroad for its reputed medicinal properties and is highly sought by herb collectors. Its rarity in Tennessee is the result of commercial exploitation. Tennessee state law specifies a harvest season (August 15-December 31) and landowner permission to dig ginseng (ginseng berries should be replanted on site).

Harvesting of ginseng in Tennessee:

According to the "Ginseng Harvest Season Act of 1985" (Acts 1985, Ch. 177, 1; Tennessee Code Annotated 11-26-101) it is unlawful in Tennessee for any person to dig, harvest, collect or remove wild ginseng from any land for the purpose of sale or export under the following circumstances:

(a) On any date not within the ginseng harvest season (harvest season is Aug. 15-Dec. 31)

(b) Plants with green berries or less than three prongs

(c) To remove the berries of wild ginseng from the approximate location harvested

(d) Plants that were harvested from any state other than Tennessee unless such ginseng has been approved for export by the state from which it was harvested

(e) Without permission of the landowner

Penalties for violation of this law, upon conviction, are a fine not to exceed $\$ 250$ and forfeiture of all ginseng harvested, collected, removed, or sold in violation of the law.

Ginseng dealers must be registered and obtain a permit from the Department of Environment and Conservation, 701 Broadway, Nashville, Tennessee 37243. Monthly records and an annual report must be filed with this department. Dealers exporting ginseng from Tennessee must attach a Tennessee ginseng export certificate with each sale of roots.

Threats on ORR: Digging to remove plants, habitat destruction, and tree canopy removal. There has been a recent (1995) increase in the price of ginseng; this may increase the demand and the frequency of poaching.

TNC ORR conservation significance: "Ginseng occurs sporadically across ORR lands. ORR populations are more protected from collection pressures (one of the main threats to the species) than populations on private or unrestricted public land. The importance of these populations needs further assessment. Populations on ORR are probably able to maintain a normal age structure." 


\subsubsection{Platanthera flava var. herbiola (R.Br.) Luer}

Common name: Tubercled rein-orchid

Family: Orchidaceae

Federal status: None

Tennessee status: Threatened

Location on ORR: BCOU4, Melton Valley GWOU, NA4, NA13, NA28, NA48, NA50, NA52

Habitat: Alluvial woods, wet meadows, and marshes (Radford et al. 1968)

Habitat on ORR: Forested wetlands and wet meadow site

Range: Nova Scotia to southern Ontario; central MN; south to MO; east to mountains of NC, VA, and TN

Tennessee counties: Anderson, Campbell, Cocke, and Roane

Description: Erect, glabrous plant with lanceolate leaves sheathing the stem, reduced to bracts on upper stem. A spike of yellow-green flowers on stems to $5 \mathrm{dm}$ in height. Floral bracts much exceed the flowers

\section{Similar species:}

1. Platanthera flava var. flava (also state listed) is not as leafy in the inflorescence.

Flowering date: May-August

Comments: Variety herbiola is the northern variety of $P$. flava and is more rare in Tennessee than the southern variety, flava. It is noteworthy that the Bear Creek wetland and Hembree Cemetery marsh both support typically northern taxa that are rare in Tennessee. Liparis loeselii, the northern counterpart of Liparis lilifolia, occurs in the forested wetland adjoining Hembree Cemetery marsh.

Threats on ORR: Habitat destruction, change in hydrologic regime (draining or flooding), and tree canopy removal

TNC ORR conservation significance: "This variety grows in several ORR wetlands; these occurrences are the largest known in Tennessee. ORR occurrences are at the southern range periphery and may represent unique genetic material. Wetlands in the Ridge and Valley province are rare and often in poor condition, while those on the ORR are in better condition."

\subsubsection{Platanthera peramoena (A.Gray) A.Gray}

Common name: Purple fringeless orchid

Family: Orchidaceae

Federal status: None (was listed under the formerly used $3 \mathrm{C}$ candidate category) 
Tennessee status: Threatened

Location on ORR: BCOU4, Melton Valley GWOU, CMA1, NA13, NA27, NA29

Habitat: Moist woods, meadows, and stream banks (Radford et al. 1968)

Habitat on ORR: Wet depressions in utility right of ways

Range: North to $\mathrm{OH}$ and $\mathrm{MO}$; south to $\mathrm{NC}, \mathrm{AL}$, and $\mathrm{TN}$

Tennessee counties: Benton, Bledsoe, Carroll, Dyer, Fayette, Henry, Johnson, McNairy, Roane, Robertson, Shelby, and Weakley

Description: Erect, glabrous herb with elliptic to lanceolate leaves. Inflorescence is a showy raceme of purple flowers up to $10.5 \mathrm{dm}$ tall.

Similar species:

1. Other pinkish flowered Platanthera have fringed flowers

Flowering date: July-August

Comments: P. flava occurs with $P$. peramoena at one site on the ORR

Threats on ORR: Habitat destruction, indiscriminate use of herbicides, invasion of woody vegetation, change in hydrologic regime (drainage or flooding), and digging by collectors

TNC ORR conservation significance: "Wetlands in the Ridge and Valley Province are rare and often in poor condition, while those on the ORR are in better condition. ORR populations are more protected from collection pressures (one of the main threats to the species) than populations on private or unrestricted public land."

\subsubsection{Pycnanthemum verticillatum (Michx.) Pers. (species cluster)}

Common name: Whorled mountain-mint

Family: Lamiaceae

Federal status: None

Tennessee status: Endangered, possibly extirpated (this may be changed because of specimens from ORR)

Location on ORR: Bethel Valley GWOU, HA8

Habitat: Woodlands and woodland borders (Radford et al. 1968)

Habitat on ORR: Wetlands and barrens 
Range: VT to OH; south to west VA; CT, MN, NY, OH, PA, TN, VA, WV, MA, MI, NJ, RI, VT, and NC

Tennessee counties: Anderson, Fentress, and Roane

Description: Pubescent and canescent perennial herb to $8 \mathrm{dm}$ in height. Stems branched in the upper part, pubescence spread over the stem surface and not confined to the angles of the square stem. Leaves narrowly lanceolate, leaf bases rounded. Reportedly entirely apomictic

Similar species: See "Comments"

Flowering date: July-September

Fruiting date: August-October

Comments: This confusing species cluster includes three rare and difficult to separate species of Pycnanthemum: $P$. verticillatum, $P$. virginiana, and $P$. torrei. Expert consultation is required for positive identification. Pycnanthemum verticillatum has not been identified recently in Tennessee and was listed as possibly extirpated. Pycnanthemum torrei has been identified in Tennessee only from a recent collection at one site in Oak Ridge. Both $P$. verticillatum (in the broad or narrow sense) and $P$. torrei are very rare in Tennessee. Pycnanthemum virginianum is not currently listed by the state but is also considered rare in Tennessee (personal communication, Paul Somers, TDEC, to L. Pounds, ORR Research Park, 1989).

TNC ORR Conservation significance: This species was not described in the ORR report.

\subsubsection{Rhynchospora colorata (L.) Pfeiffer}

Common name: White-topped sedge

Family: Cyperaceae

Federal status: None

Tennessee status: Special Concern

Location on ORR: NA46

Habitat: "Damp, often sandy soil" (Gleason and Cronquist 1991)

Habitat on ORR: Limestone quarry, just above water line

Range: VA to Mexico and West Indies

Tennessee counties: Roane

Description: Tufted perennial herb with solitary terminal inflorescence atop triangular stem, 
5-6 dm tall. The inflorescence is distinctive, surrounded by 4-6 bicolored bracts which are white at the bases and green at the tips. The bracts are unequal in length. The narrowly linear leaves are usually shorter than the stem.

Similar species:

White-topped sedges are distinctive and all are rare or unknown in Tennessee

Flowering date: May-September

Fruiting date: July-October.

Comments: Currently the only verified population for Tennessee

Threats on ORR: Habitat destruction, digging up for transplanting

TNC ORR conservation significance: This species was not described in the ORR report

\subsubsection{Ruellia purshiana Fern.}

Common name: Pursh's wild-petunia

Family: Acanthaceae

Federal status: None

Tennessee status: Special Concern

Location on ORR: Melton Valley GWOU, NA51, NA53

Habitat: Rocky upland woods

Habitat on ORR: Partly shaded rocky limestone slope

Range: Appalachian region from $M D$ to $G A$ and $A L$

Tennessee counties: Hawkins, Roane

Description: A blue-flowered herb (3-7 dm tall). Leaves petiolate and flowers short-pediceled on peduncles from middle nodes. Stem equally hairy on all sides.

Similar species:

1. $R$. strepens has wider calyx lobes ( $2 \mathrm{~mm}$ or more).

2. $R$. humilis has shorter petioles ( $3 \mathrm{~mm}$ or less).

3. $R$. carolina has two sides of the stem hairier than the other two.

Flowering date: June-August

Comments: Taxonomic problems may exist within this genus (Ruellia) 
Threats on ORR: Habitat destruction

TNC ORR conservation significance: This species was identified on the ORR after the ORR report

\subsubsection{Saxifraga careyana A. Gray}

Common name: Carey saxifrage

Family: Saxifragaceae

Federal status: None (was listed under the formerly used $3 \mathrm{C}$ candidate category)

Tennessee status: Special Concern

Location on ORR: NA1, NA3, NA5, NA11, NA15, NA16, NA17, NA18, NA21, NA23

Habitat: Moist rocks and seepage slopes (Radford et al. 1968)

Habitat on ORR: Rocky, calcareous bluffs and sinks along the Clinch River

Range: GA, MA, NC, PA, TN, and VA

Tennessee counties: Anderson, Bledsoe, Blount, Carter, Cocke, Franklin, Grainger, Hamilton, Hancock, Knox, Loudon, Marion, Monroe, Pickett, Polk, Rhea, Roane, Sevier, Sullivan, Unicoi, and Van Buren

Description: Small, perennial herb forming rather fleshy rosettes and short offsets from the crown. Hairy leaves are slightly concave on the upper surface, rounded and frequently reddish on the underside. White to pale-pink flowers with scapes up to $3 \mathrm{dm}$ tall

\section{Similar species:}

1. S. caroliniana is similar but it has clavalate filaments

Flowering date: April-June

Fruiting date: May-June

Comments: The taxonomy of S. careyana and S. caroliniana is confusing, so much so that the species have been called "the careyana-caroliniana complex." $S$. caroliniana is a federal "Species of Concern" (listed under the formerly used C2 candidate category) and is listed as endangered in Tennessee. Some of the populations on the ORR have not been surveyed in the flowering stage, a stage necessary to distinguish the two species. Saxifraga caroliniana is not reported to occur in the Ridge and Valley Province in eastern Tennessee, so these populations are most likely S. careyana. Rare species that co-occur with $S$. careyana on the ORR are Aureolaria patula, Cimicifuga rubifolia, and Diervilla lonicera.

Threats on ORR: Habitat destruction, tree canopy removal, erosion and siltation related to upslope timber removal or development 
TNC ORR conservation significance: “ORR represents an important concentration of populations of this narrowly distributed endemic."

\subsubsection{Scirpus fluviatilis (Torr.) A. Gray}

Common name: River bulrush

Family: Cyperaceae

Federal status: None

Tennessee status: Special Concern

Location on ORR: Melton Valley GWOU, WAG 2, CMAS

Habitat: Open wetland

Habitat on ORR: Wetland at the edge of White Oak Lake

Range: Northern U.S. and southern. Canada, south to VA, MO, KS and now disjunct to TN

Tennessee counties: Henry, Roane

Description: Grass-like plant with stout triangular shaped stem (6-15 dm tall). Normally does not fruit in consecutive years

Flowering date: June-August

Fruiting date: Summer

Comments: The ORR occurrence of this species is the second known for the southeastern U.S.

Threats on ORR: Habitat destruction; the habitat could be destroyed during contamination remediation projects on White Oak Lake.

TNC ORR conservation significance: This species was discovered prior to the ORR report but was apparently overlooked by TNC

\subsubsection{Spiranthes lucida (H. Eaton) Ames}

Common name: Shining ladies'-tresses

Family: Orchidaceae

Federal status: None

Tennessee status: Threatened

Location on ORR: NA33 
Habitat: Moist calcareous sites

Habitat on ORR: Wetland under shrub cover

Range: Canada south to KY, TN, WV

Tennessee counties: Claiborne, Franklin, Johnson, Lewis, Roane

Description: Ladies'-tresses are small orchids. Shining ladies'-tresses is distinguished by its bright yellow lip and spring blooming

Flowering date: May-July

Threats on ORR: Habitat destruction, change in hydrologic regime (drainage or flooding). This species is currently (1995) near construction activity.

TNC ORR conservation significance: This species was discovered on the ORR after TNC report.

\subsubsection{Spiranthes ovalis Lindl.}

Common name: Lesser ladies'-tresses

Family: Orchidaceae

Federal status: None

Tennessee status: Special Concern

Location on ORR: CROU2, Melton Valley GWOU, WAG 2, CMA4, CMA5, NA9, NA10

Habitat: Moist, shady woods, thickets, and swamp margins (Radford et al. 1968)

Habitat on ORR: Moist second-growth woods

Range: AR, DC, FL, GA, IL, IO, KS, KY, LA, MI, MS, MO, OH, OK, PA, SC, TN, VA, WI, and WV

Tennessee counties: Anderson, Cannon, Franklin, Lake, Lewis, Montgomery, Obion, Putnam, Roane, Sevier, Tipton, and Warren

Description: Erect stems to $4.5 \mathrm{dm}$ tall with two-four basal oblanceolate leaves. Small white flowers are congested on the slender spike

Similar species:

1. S. cernua has larger flowers (over $7.5 \mathrm{~mm}$ )

2. S. lacera has greenish lip.

Flowering date: August-November 
Fruiting date: October-November

Comments: Ginseng and goldenseal co-occur with $S$. ovalis on the ORR.

Threats on ORR: Habitat destruction and tree canopy removal

TNC ORR conservation significance: "The significance of these populations needs further assessment."

\subsubsection{Viola tripartita Elliot var. tripartita}

Common name: Three-parted violet

Family: Violaceae

Federal status: None

Tennessee status: Special Concern

Location on ORR: NA51

Habitat: Rich woods

Habitat on ORR: Cherty soil under mixed white pine and hardwoods in an area of shallow sinkholes

Range: (the following is the range of the species rather than the range of this variety) southwestern $\mathrm{PA}$ and southern $\mathrm{OH}$ to $\mathrm{NC}$ and $\mathrm{SC}, \mathrm{GA}, \mathrm{AL}$, and northeastern MS

Tennessee counties: Roane (ORR) and possibly Hamilton

Description: A yellow-flowered violet with a "leafy stem," the early leaves are dissected into three leaflets in this variety

Similar species:

1. Viola tripartita var. glaberrima may have cleft leaves but not so deeply cleft as to form leaflets.

Flowering date: April-May

Comments: Both varieties of Viola tripartita are found on the ORR. On the ORR these varieties are distinct, showing no tendency to intergrade, and are found in different habitats with var. tripartita found in a drier habitat.

Threats on ORR: Habitat destruction, removal of tree canopy (and subsequent erosion of substrate)

TNC ORR conservation significance: This species was discovered on the ORR after TNC report. 
3.4.2 Additional T\&E Vascular Plant Species That Occur Near And May Be Present on the ORR

\subsubsection{Berberis canadensis Mill.}

Common name: Barberry

Family: Berberidaceae

Federal status: None

Tennessee status: Special concern

Habitat: Rocky bluffs, creek banks and roadsides (Radford et al. 1968)

Habitat near ORR: Rocky bluff on Tennessee River

Range: VA and WV to GA and $A L ; M O$ and IN

Tennessee counties: Cumberland, Hawkins, Knot, Knox, Morgan, Sullivan, and Washington

Description: Deciduous shrub 2-20 dm in height with three-pronged thorns. Leaves alternate, ovate or elliptic to obovate. Berries scarlet, 5-7 mm long

Flowering date: April-May

Fruiting date: September-October

Locations near ORR: Rocky bluffs along Tennessee River in Knox Co.

Comments: An immature specimen of $B$. canadensis or a similar species was collected on the ORR in 1983. It is not possible to positively identify the specimen collected, and in a subsequent search for $B$. canadensis in the area of collection, no individuals were observed. The species may be present on the ORR on rocky bluffs along Clinch River or on creek banks.

\subsubsection{Gnaphalium helleri Britt.}

Common name: Catfoot

Family: Asteraceae

Federal status: None

Tennessee status: Special Concern

Habitat: Openings in woods and woodland borders (Radford et al. 1968)

Habitat near ORR: Dry woodland edge 
Range: $\mathrm{ME}$ to $\mathrm{GA} ; \mathrm{IN}, \mathrm{AR}$, and TX

Tennessee counties: Blount, Grundy, and Roane

Description: Annual with lanceolate leaves not decurrent on stem. Green, conspicuously hairy stem with greater than 15 leaves below the infloresence

Flowering date: September-October

Fruiting date: September-October

Locations near ORR: Dry, calcareous soil adjacent to the Clinch River, formerly part of the ORR, now owned by Boeing Tennessee, Inc.

Comments: Specimen collected in 1983 on Campbell Bend. The species may be present on the ORR on barren openings or dry woodland edges.

\subsubsection{Liatris cylindracea Michx.}

Common name: Slender blazing star

Family: Asteraceae

Federal status: None

Tennessee status: Endangered

Habitat: Dry, open places (Gleason 1952)

Habitat near ORR: Open, dry, calcareous barrens

Range: West NY and south Ontario to south OH; north IN, MI, MN, then south to north AR

Tennessee counties: Decatur, Marion, Roane, and Rutherford

Description: Glabrous perennial with numerous stiff, linear leaves. Pink-purple, discoid flowers on stalks to $6 \mathrm{dm}$ tall. Involucral bracts appressed, broadly rounded, and mucronate

Flowering date: August-September

Fruiting date: September-October

Locations near ORR: Dry, calcareous barren at Campbell Bend on the Clinch River, locally called the Crowder Cemetery Barren. Formerly part of NA1 the land is now owned by Boeing Tennessee, Inc. The barren is protected by an agreement between TDEC and Boeing and is a registered Tennessee Natural Area. Last observed in 1990. Roane County

Comments: Other rare species that co-occur with L. cylindracea at the Crowder Cemetery Barren are Tomanthera auriculata, Solidago ptarmicoides, and Delphinium exaltatum. Liatris squarrosa 
also occurs at this site, and an apparent blending of morphological characteristics suggests that it may be hybridizing with $L$. cylindracea. Liatris cylindracea may be present on the ORR on barrens.

\subsubsection{Lonicera dioica $\mathrm{L}$.}

Common name: Mountain honeysuckle

Family: Caprifoliaceae

Federal status: None

Tennessee status: Special Concern

Habitat: Woodlands and thickets (Radford et al. 1968)

Habitat near ORR: Rocky river banks

Range: Southwest ME and southwest Quebec to Manitoba; south to GA and MO

Tennessee counties: Anderson, Cheatham, Johnson, Polk, Marion, and Roane

Description: Climbing vine with glabrous stems. Leaves glaucous beneath. Inflorescence a terminal spike, corollas less than $3 \mathrm{~cm}$ long. Ovaries not fused

Flowering date: June-August

Fruiting date: August-September

Locations near ORR: Rocky banks of the Emory River near Harriman

Comments: The species may be present on the ORR on rocky banks and bluffs on Clinch River and its tributaries.

\subsubsection{Meehania cordata (Nutt.) Britt.}

Common name: Heartleaf meehania

Family: Lamiaceae

Federal status: None

Tennessee status: Threatened

Habitat: Rich, wooded slopes and coves (Radford et al. 1968)

Habitat near ORR: Wooded, calcareous slope along Clinch River

Range: Southwest PA and south $\mathrm{OH}$ to TN and NC; IL 
Tennessee counties: Anderson

Description: Perennial herb spreading by stolons and forming carpets. Erect flowering stems to $2 \mathrm{dm}$ tall. Four anther-bearing stamens, four-parted ovary, basal style, and flowers more than $2 \mathrm{~cm}$ long

Flowering date: May-June

Fruiting date: June-July

Locations near ORR: On a wooded slope near Norris Lake on Clinch River. Anderson County

Comments: The species may be present on the ORR on rich, wooded slopes along Clinch River and its tributaries.

\subsubsection{Pedicularis lanceolata Michx.}

Common name: Swamp lousewort

Family: Scrophulariaceae

Federal status: None

Tennessee status: Threatened

Habitat: Wet meadows on basic soils (Radford et al. 1968)

Habitat near ORR: Wet meadow/seep at base of ridge

Range: MA to MI, MN, MAN, and ND; south to NC, MO, and NE

Tennessee counties: Roane and Union

Description: Perennial with basal rosette. Stems to $8 \mathrm{dm}$ in height. Leaves sessile, lanceolate and shallowly, crenately lobed. Corolla yellow

Flowering date: August-October

Fruiting date: September-October

Location near ORR: Wet meadow off Highway 72 south of Kingston. On private property. Last observed in 1992. Roane County

Comments: No other listed plant species co-occur with $P$. lanceolata at this site. This species may be present on the ORR on wet meadows and on seeps.

\subsubsection{Solidago ptarmicoides (Nees) Boivin}

Common name: Prairie goldenrod 
Family: Asteraceae

Federal status: None

Tennessee status: Endangered

Habitat: Prairies and open dry places (Gleason 1952)

Habitat near ORR: Dry, calcareous barren

Range: VT and west Quebec to GA; west to Saskatchewan, WY, CO, and AR; CT, CO, GA, IA, IL, MA, MN, MO, NC, ND, NY, OK, PA, SD, TN, WI, KS, WY, NE, OH, and VT

Tennessee counties: Anderson, Rhea, and Roane

Description: Scabrous perennial to $7 \mathrm{dm}$ tall. Leaves stiff, linear-oblanceolate to linear. Infloresence corymbiform, rays and disk of flowers are white

Flowering date: July-September

Fruiting date: September-October

\section{Locations near ORR:}

1. Dry, calcareous barren on Campbell Bend in Clinch River, locally called the Crowder Cemetery Barren. Formerly part of NAl, the land is now owned by Boeing Tennessee, Inc. The barren is protected by an agreement between TDEC and Boeing and is a registered Tennessee Natural Area. Last observed in 1990. Roane County

2. Dry, calcareous opening at the Oak Ridge Barrens, a registered Tennessee Natural Area owned by the City of Oak Ridge, next to Jefferson Junior High School. Last observed in 1990. Anderson County

COMMENTS: Other rare species that co-occur with S. ptarmicoides at sites near the ORR are Liatris cylindracea, Tomanthera auriculata, and Delphinium exaltatum. Solidago ptarmicoides may be present on the ORR on barrens. Solidago ptarmicoides was planted in the Environmental Sciences Division's (ORNL) Barrens Research Garden and has been reproducing very successfully.

\subsubsection{Tomanthera auriculata (Michx.) Raf.}

Common name: Earleaf foxglove

Family: Scrophulariaceae

Federal status: SPC

Tennessee status: Endangered

Habitat: Dry or moist soil, in prairies or open, upland woods (Gleason 1952)

Habitat near ORR: Calcareous barren 
Range: $\mathrm{OH}$ to $\mathrm{WI}$ and $\mathrm{MN}$; south to $\mathrm{MO}$ and $\mathrm{KS}$; also locally in southern states; $\mathrm{AR}, \mathrm{PA}, \mathrm{MO}, \mathrm{MS}$, $\mathrm{KS}, \mathrm{IA}, \mathrm{IL}, \mathrm{OH}, \mathrm{TN}$, and $\mathrm{SC}$

Tennessee counties: Bledsoe, Carroll, and Roane

Description: Hemiparasitic, annual herb to $8 \mathrm{dm}$ in height. Foliage purple-green when in full sun. Upper leaves with divergent basal auricles. Flowers sessile in leafy spikes, corolla pink with purple spots on throat

Flowering date: August-September

Fruiting date: September-October

Locations near ORR: Bottom of gentle slope on dry, calcareous barren near Clinch River. Population size estimated to be 2400. Last observed in 1990. Roane County

Comments: Tomanthera auriculata is a hemiparasite that forms haustoria on roots of Helianthus occidentalis, Solidago rigida, and Rudbeckia fulgida. In the field a host is apparently necessary for normal growth and flowering (Cunningham and Parr 1990). Other rare species that co-occur with $T$. auriculata at this site are Liatris cylindracea, Solidago ptarmicoides, and Delphinium exaltatum. Tomanthera auriculata may be present on the ORR on barrens. 


\section{RECOMMENDATIONS}

\subsection{FOLLOW-UP SURVEYS}

\subsubsection{Future Surveys at Environmental Restoration Remediation Sites}

Systematic T\&E vascular plant surveys are necessary prior to initiation of remediation or other project activities at a site when any of the following conditions apply:

- The area has never been surveyed using systematic ground coverage.

- The area has not been surveyed in multiple seasons.

- The area has not been surveyed within 5 years prior to the commencement of activities at the site.

\subsubsection{Additional Surveys}

Follow-up surveys may be required in the future. Follow-up surveys for T\&E vascular plants are recommended for the following reasons:

- Detailed T\&E vascular plant surveys (which include systematic ground coverage and multiple season site visits) have not been performed for large areas of the ORR. The existence of additional sites for $T \& E$ vascular plant species, which were not detected during this survey, is likely.

- Additional species (not investigated in this survey) may be added to state and federal lists in the future.

- Under certain environmental conditions, some rare plants, including T\&E species that have been found on the ORR, may undergo prolonged periods of dormancy in which the individual or population exists for many years either as rhizomes (underground) or as propagules in soil seedbanks. Such species may not have been detected during this survey and may "re-appear" after extended intervals.

- Plants, including T\&E species, will sometimes occur in atypical habitats. An example of a rare taxon occurring in an atypical habitat on the ORR is heavy sedge (Carex gravida), a prairie species typical of open sites, which has been found at two forested sites on the ORR. Rare taxa in atypical habitats may be less likely to be discovered because (1) the habitat is not identified during the initial survey as potential habitat for the taxon, (2) the field botanist might not be using that particular search image if the taxon is not expected to occur in the habitat, or (3) the taxon might have an unusual growth form because of habitat location and thus differ from the botanist's search image.

\subsection{MAINTENANCE AND UPDATE OF DATABASES AND VOUCHER COLLECTION}

The following data generated during this project will be submitted to OREIS:

- Sample point locations for T\&E vascular plant species (GIS coverage)

- ORR environmentally sensitive areas (GIS coverage) 
- T\&E vascular plant survey coverage data (GIS coverage)

- ORR vascular flora data base (spreadsheet data)

Data bases and collections documenting T\&E species on the ORR that are not submitted to OREIS (because they do not fit OREIS data requirements) are also valuable resources. Readily available access to updated T\&E data sources would facilitate future compliance with environmental regulations. Specifically, the following resources should be maintained:

- Voucher specimen collection (ORNL herbarium)

- T\&E photographic collection (negatives maintained by ORNL Photography Department)

- ORR Heritage data base (maintained by ORNL area manager)

\subsection{AVOIDANCE OF ORR ENVIRONMENTALLY SENSITIVE AREAS}

Protection of T\&E species in their natural habitats is the most effective method of ensuring their long-term survival. ORR environmentally sensitive areas include T\&E species and their habitats, sensitive landscape elements and rare natural communities associated with T\&E species, as well as necessary buffers. Project planners should seriously consider avoiding altogether or taking extra precautions in areas designated as ORR environmentally sensitive areas (Fig. 5).

\subsection{IMPACT ASSESSMENT}

\subsubsection{Scale of Concern}

Impacts to T\&E species on the ORR should be considered at both local and regional scales. Impacts to sensitive species and natural communities on the ORR may have regional consequences. Although the original forests had been cleared, and the land was in agriculture at the time the ORR was purchased by the U.S. government in 1942, much of the ORR has been relatively undisturbed since 1942, and many areas have been allowed to undergo natural succession. In contrast, the land surrounding the ORR has either remained in agriculture or been developed for commercial, industrial, and residential purposes. As a result, the natural vegetation on the ORR has become increasingly significant in relation to regional biodiversity. TNC reports that ORR natural habitats "provide a refuge for many plants, animals and natural communities that are disappearing from surrounding lands..." (TNC 1995). This significance is evident in the significant number of T\&E vascular plant species (Table 3) and rare natural communities (TNC 1995; Grossman, Goodin, and Reuss 1994) found on the ORR. One T\&E plant species on the ORR (Rhynchospora colorata) is currently known from no other location in the state of Tennessee.

\subsubsection{Threats to T\&E Vascular Plant Species}

Project activities on the ORR may have the potential to adversely impact T\&E species both directly and indirectly. Adverse impacts to $T \& E$ plants, both to $T \& E$ plants on site (direct) and to $T \& E$ plants off site (indirect) may occur on the ORR as a result of :

- predevelopment site monitoring and characterization activities;

- installation of equipment (for monitoring or infrastructure); 
- use of earth-moving equipment;

- road building;

- $\quad$ site preparation, grading, and landscaping;

- construction of facilities;

- disposal of waste materials;

- alteration of hydrologic regime (drainage of water or flooding);

- timber removal;

- mowing; and

- pesticide application.

Direct threats to T\&E plants include removal, burial, poisoning, or otherwise physically damaging the plants themselves, and direct disturbance or destruction of their habitats. Indirect impacts to T\&E species occur as a result of project activities but do not involve direct contact or interference with the plants themselves. Indirect threats to T\&E plants include the following.

- Habitat fragmentation: loss of landscape connectivity between areas of natural habitat. Habitat connectivity may be necessary to allow genetic exchange between populations or to support or allow access to the habitat by animals which carry the seeds.

- Creation of disturbed openings and additional forest edges: these openings provide an entry route for the invasion of $T \& E$ species habitats by competing weedy species.

- Planting of aggressive or persistent exotic (also known as "non-native" or "introduced") species (for erosion control, site stabilization, reforestation, landscaping, etc.): exotic species may subsequently migrate from the target site and compete with T\&E species. Over 190 species of vascular plants that are not native to this region have been found growing wild on the ORR to date. Exotic plant species currently associated with adverse impact to T\&E species or have a high potential to adversely impact T\&E species are listed in Table 9.

- Exposure of T\&E plants to damaging agents (including insect pests, diseases, grazing by deer, and picking or digging of plants by humans) as a result of increasing access to the site.

- Reduction of pollinators (through loss of supporting habitat or poisoning): loss of pollinators may result in reproductive failure in the plant species. Many types of insects, and some birds and mammals (such as bats) may act as plant pollinators.

- Creation or loss of shade: plant species are adapted to growth under particular light levels, and within particular microclimates. Changes in light level directly affect a plant's ability to photosynthesize and grow and drive other changes in the site microclimate such as increasing dryness or humidity. Such changes may allow competing weedy species to invade the site.

- Fire suppression: some T\&E plant species, particularly those associated with calcareous barrens, may require fire to maintain their habitat open.

- Changes in maintenance activities in T\&E plant zones (such as those within utility corridors and hay fields): timing of mowing and/or other maintenance activities to avoid blooming and fruiting periods may be critical to the survival of populations of T\&E plants in maintained areas. 
- Erosion and/or siltation resulting from up-slope activities (including facility maintenance, timber removal, and excavations): adverse impacts of site runoff and sediment movement to nearby T\&E plant may include burial, drowning, root exposure, scouring, or up-rooting.

- Chemical changes: input or diversion of nutrients may adversely affect sensitive species. 


\section{REFERENCES}

Chester, E. W., et al. 1993. Atlas of Tennessee Vascular Plants, Vol. 1; Pteridophytes, Gymnosperms, Angiosperms: Monocots. Miscellaneous Publication Number 9, The Center for Field Biology, Austin Peay State University, Clarksville, Tenn.

Cronquist, A. 1980. Vascular Flora of the Southeastern United States, Vol. 1. The University of North Carolina Press, Chapel Hill, N.C.

Cunningham, M., et al. 1993. Resource Management Plan for the Oak Ridge Reservation, V. 29: Rare Plants on the Oak Ridge Reservation, Environmental Sciences Division Publication No. 3995, Oak Ridge National Laboratory, Oak Ridge, Tenn.

Gleason, H. A. 1952. The New Britton and Brown Illustrated Flora of the Northeastern United States and Canada, The New York Botanical Garden, Bronx, N.Y.

Gleason, H. A., and A. Cronquist 1991. Manual of Vascular Plants of Northeastern United States and Adjacent Canada, 2nd ed. The New York Botanical Garden, Bronx, N.Y.

Grossman, D. H., K. L. Goodin, and C. L. Reuss, eds. 1994. Rare Plant Communities of the Conterminous United States; An Initial Survey. The Nature Conservancy, Arlington, Va. Prepared for the U.S. Fish and Wildlife Service under contract with The Idaho Cooperative USFWS Research Unit, p. 620.

King, A. L., D. J. Awl, and C. A.Gabrielsen 1994. Environmentally Sensitive Areas Surveys Program Threatened and Endangered Species Survey Progress Report, ES/ER/TM-130, Health Sciences Research Division, Oak Ridge National Laboratory, Oak Ridge, Tenn.

Kral, R. 1983. A Report on Some Rare, Threatened, or Endangered Forest-Related Vascular Plants of the South. USDA Forest Service, Technical Publication R8-TP 2.

Massey, J. R., et al. 1983. An Atlas and Illustrated Guide to the Threatened and Endangered Vascular Plants of the Mountains of North Carolina and Virginia, USDA Forest Service, General Technical Report SE-20.

Pounds, L. R., P. D. Parr, and M. G. Ryon 1993. Resource Management Plan for the Oak Ridge Reservation, V.30: Oak Ridge National Environmental Research Park Natural Areas and Reference Areas-Oak Ridge Reservation Environmentally Sensitive Sites Containing Special Plants, Animals, and Communities, Environmental Sciences Division publication No.4054, Oak Ridge National Laboratory, Oak Ridge, Tenn.

Pyne, M., and A. Shea 1994a. Guide to the RarePlants; Tennessee Forestry District 1, Tennessee Department of Environment and Conservation.

Pyne, M., and A. Shea 1994b. Guide to the RarePlants; Tennessee Forestry District 2, Tennessee Department of Environment and Conservation.

Pyne, M., and A. Shea 1994c. Guide to the RarePlants; Tennessee Forestry District 3, Tennessee Department of Environment and Conservation. 
Radford, A. E., H. E. Ahles, and C. R. Bell-1968. Manual of the Vascular Flora of the Carolinas, The University of North Carolina Press, Chapel Hill, N.C., p. 1183.

TNC (The Nature Conservancy) 1995. Oak Ridge Reservation, Biodiversity, and the Common Ground Process, Preliminary Biodiversity Report on the Oak Ridge Reservation.

Wofford, B. E. 1989. Guide to the Vascular Plants of the Blue Ridge, The University of Georgia Press, Athens and London. 
Appendix A

TABLES 


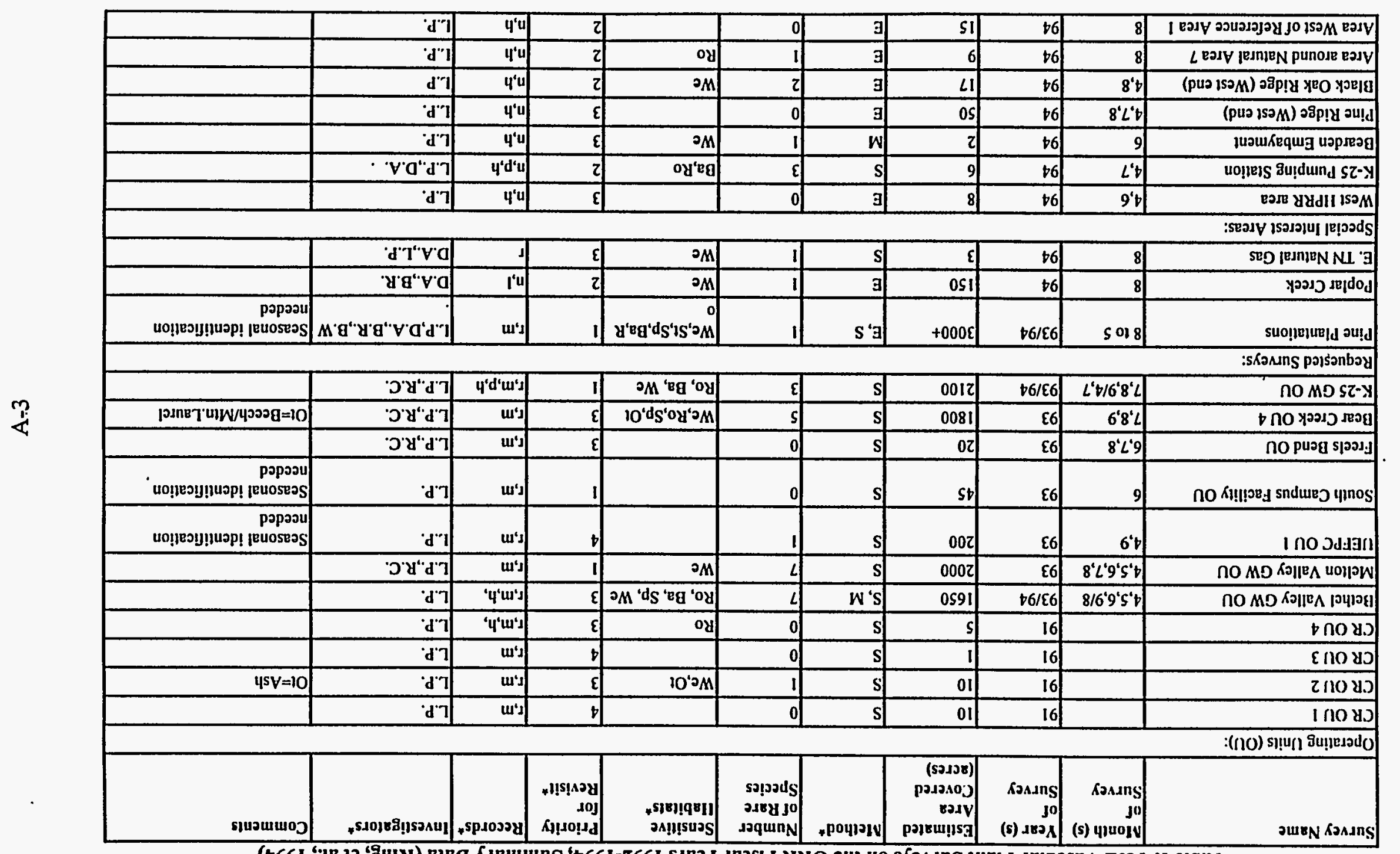

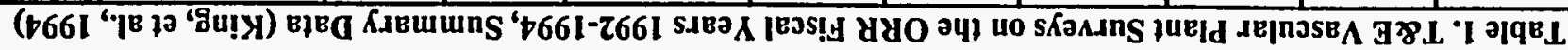


Table 1. (continued)

1

\begin{tabular}{|c|c|c|c|c|c|c|c|c|c|c|}
\hline Survey Name & $\begin{array}{l}\text { Month (s) } \\
\text { of } \\
\text { Survey }\end{array}$ & $\begin{array}{l}\text { Year (s) } \\
\text { of } \\
\text { Survey }\end{array}$ & \begin{tabular}{|l|} 
Estimated \\
Area \\
Covered \\
(acres)
\end{tabular} & Miethod* & $\begin{array}{l}\text { Number } \\
\text { of Rare } \\
\text { Species }\end{array}$ & $\begin{array}{l}\text { Sensitive } \\
\text { Ilabitats* }\end{array}$ & $\begin{array}{l}\text { P'riority } \\
\text { for } \\
\text { Revisit* }\end{array}$ & Records* & Investigators* & Comments \\
\hline \multicolumn{11}{|c|}{ National I:nvironmental Rescarch Park Sensitive Areas: } \\
\hline Natural Arca 22 & 6 & 94 & 3 & $S, M$ & 2 & Ro & 2 & $\mathrm{r}, \mathrm{d}$ & R.C.,D.A. & \\
\hline Natural Area 25 & 6 & 94 & 9 & $\mathrm{~S}, \mathrm{M}$ & 1 & St & 1 & $\mathrm{r}, \mathrm{d}$ & R.C.,D.A. & \\
\hline Natural Arca 26 & 6 & 94 & 2 & $\mathrm{~S}, \mathrm{M}$ & 2 & Ro & 1 & $r, d$ & R.C.,D.A. & \\
\hline Reference Area 29 & 6 & 94 & 6 & $S, M$ & 1 & We & 4 & $r, d$ & R.C.,D.A.,L.P. & \\
\hline Natural Area 11 & 7 & 94 & 2 & $S, M$ & 1 & St & 4 & $r, d$ & R.C. & \\
\hline Nalural Arca 13 & 7 & 94 & 1 & $S, M$ & 1 & We & 3 & $r, d$ & R.C.,D.A. & \\
\hline Nalural Area 14 & 7 & 94 & 5 & $S, M$ & 1 & We,Ot & 4 & $r, d$ & R.C.,D.A & Ot=upland grasslands \\
\hline Natural Area 21 & 7 & 94 & 3 & $\mathbf{S}, \mathbf{M}$ & 0 & $0 t$ & 4 & $r, d$ & R.C.,D.A. & Ot=rocky limestone forest \\
\hline Natural Area 2 & 7,8 & 94 & 10 & $S, M$ & 1 & $\mathrm{Ba}$ & 4 & $r, d$ & R.C. & . \\
\hline Natural Area 10 & 8 & 94 & 2 & $\mathbf{s}$ & 4 & $\mathrm{Ra}, \mathrm{Ot}$ & 4 & $r, d$ & R.C.,D.A. & Ot=mature mesic hardwood \\
\hline Natural Area 27 & 8 & 94 & 1 & $S$ & 1 & $\mathrm{We}, \mathrm{Ba}$ & 1 & $n$ & R.C.,D.A. & \\
\hline Natural Area 7 & 8 & 94 & 4 & $\mathbf{S}$ & 1 & $\mathrm{Ba}$ & 4 & $r, d$ & R.C. & \\
\hline Natural Area 8 & 8 & 94 & 5 & $s$ & 3 & Ro, We & 1 & $n$ & D.A.,L.P. & $\begin{array}{l}\text { Seasonal identification } \\
\text { needed }\end{array}$ \\
\hline Natural Area 24 & 8 & 94 & 2 & $M$ & 1 & We & 3 & $n, h$ & L.P. & \\
\hline Reference Area 1 & 8 & 94 & 5 & $E$ & 1 & Ro & 2 & $n, h$ & L.P. & \\
\hline Natural Area 19 & 8 & 94 & 10 & E,M & 1 & Ro & 3 & n & L.P. & \\
\hline
\end{tabular}

* Explanation of Codes

Methods:

$E=$ Exploratory Survey

$S=$ Systematic Survey

$\mathrm{M}=$ Population

Monitoring
Sensitive Habitats:

We $=$ Wetlands

$\mathrm{St}=$ Stream

$\mathrm{Sp}=$ Spring

$\mathrm{Ba}=$ Barrens

Ro=Cliff/Rock Outcrop

$\mathrm{O} t=\mathrm{Other}$
Priority for Revisit:

I=Highest

4=Lowest

Records:

rereport

$\mathrm{m}=$ maps

$d=$ data sheets

$\mathrm{h}=$ herbarium specimen

$\mathrm{p}=$ photographs

$\mathrm{n}=$ field notes

I=species list
Investigators:

B.R. = Barbara

Rosensteel

B.W.=Beth Wade

D.A. $=$ Deborah Awl

L.P. =Larry Pounds

R.C.=Rebecca Cook 
Table 1. (continued)

\begin{tabular}{|c|c|c|c|c|c|c|c|c|c|c|}
\hline Survey Name & $\begin{array}{l}\text { Month (s) } \\
\text { of } \\
\text { Survey }\end{array}$ & $\begin{array}{l}\text { Year (s) } \\
\text { of } \\
\text { Survey }\end{array}$ & $\begin{array}{l}\text { Estimated } \\
\text { Area } \\
\text { Covered } \\
\text { (acres) }\end{array}$ & Miethod" & $\begin{array}{l}\text { Number } \\
\text { of Rare } \\
\text { Species }\end{array}$ & \begin{tabular}{|l} 
Sensitive \\
Ilabitats*
\end{tabular} & $\begin{array}{l}\text { Priority } \\
\text { for } \\
\text { Revisit" }\end{array}$ & Records $^{\star}$ & Investigators* & Comments \\
\hline \multicolumn{11}{|c|}{ National Environmental Research Park Sensitive Areas: } \\
\hline Natural Area 22 & 6 & 94 & 3 & $S, M$ & 2 & Ro & 2 & $r, d$ & R.C.,D.A. & \\
\hline Natural Area 25 & 6 & 94 & 9 & $S, M$ & 1 & St & 1 & $r, d$ & R.C.,D.A. & \\
\hline Natural Area 26 & 6 & 94 & 2 & S,M & 2 & Ro & I & $\mathrm{r}, \mathrm{d}$ & R.C.,D.A. & \\
\hline Reference Area 29 & 6 & 94 & 6 & S,M & 1 & We & 4 & $r, d$ & R.C.,D.A.,L.P. & \\
\hline Nalural Area II & 7 & 94 & 2 & $S, M$ & 1 & St & 4 & $r, d$ & R.C. & \\
\hline Natural Area 13 & 7 & 94 & 1 & $S, M$ & 1 & We & 3 & $r, d$ & R.C.,D.A. & \\
\hline Nalural Arca 14 & 7 & 94 & 5 & $S, M$ & 1 & We,Ot & 4 & $r, d$ & R.C.,D.A & $O \mathrm{O}=$ upland grasslands \\
\hline Natural Area 21 & 7 & 94 & 3 & $S, M$ & 0 & 0 & 4 & $\mathrm{r}, \mathrm{d}$ & R.C.,D.A. & Ot=rocky limestone forest \\
\hline Natural Area 2 & 7,8 & 94 & 10 & $S, M$ & 1 & $\mathrm{Ba}$ & 4 & $\mathrm{r}, \mathrm{d}$ & R.C. & \\
\hline Nalural Area 10 & 8 & 94 & 2 & $s$ & 4 & $\mathrm{Ra}, \mathrm{Ot}$ & 4 & $r, d$ & R.C.,D.A. & $O t=$ mature mesic hardwood \\
\hline Natural Area 27 & 8 & 94 & 1 & $s$ & 1 & $\mathrm{We}, \mathrm{Ba}$ & 1 & $n$ & R.C.,D.A. & \\
\hline Natural Area 7 & 8 & 94 & 4 & $s$ & 1 & $\mathrm{Ba}$ & 4 & $r, d$ & R.C. & \\
\hline Natural Area 8 & 8 & 94 & 5 & $s$ & 3 & Ro, We & 1 & $n$ & D.A.,L.P. & $\begin{array}{l}\text { Seasonal identification } \\
\text { needed }\end{array}$ \\
\hline Natural Area 24 & 8 & 94 & 2 & $M$ & 1 & We & 3 & $n, h$ & L.P. & \\
\hline Reference Area I & 8 & 94 & 5 & $E$ & 1 & Ro & 2 & $n, h$ & L.P. & \\
\hline Natural Area 19 & 8 & 94 & 10 & $E, M$ & 1 & Ro & 3 & n & L.P. & \\
\hline
\end{tabular}

* Explanation of Codes

Methods:

$E=$ Exploratory Survey

$S=$ Systematic Survey

$M=$ Population

Monitoring
Sensitive Habitats:

$\mathrm{We}=$ Wetlands

St=Stream

Sp=Spring

$\mathrm{Ba}=$ Barrens

$\mathrm{Ro}=$ Cliff/Rock Outcrop

$\mathrm{O}=\mathrm{O}$ ther
Priority for Revisit:

1=Highest

$4=$ Lowest
Records:

r=report

$\mathbf{m}=$ maps

$d=$ data sheets

$\mathrm{h}=$ herbarium specimen

$\mathrm{p}=$ photographs

$\mathrm{n}=$ field notes

I=species list
Investigators:

B.R.= Barbara

Rosensteel

B.W.=Beth Wade

D.A. =Deborah Awl

L.P. $=$ Larry Pounds

R.C.=Rebecca Cook 
A-6..

Table 2. T\&E Vascular Plant Surveys on the ORR Fiscal Years 1995-1996, Summary Data

\begin{tabular}{|c|c|c|c|c|c|}
\hline INDEX & DATE & SITE & REQUEST & ACRES & INVESTIGATOR \\
\hline & & & & & \\
\hline 1 & $1 / 16 / 95$ & W of 0907 & & 29.67 & L.P. \\
\hline 2 & $1 / 17 / 95$ & E and $S$ of 0907 & & 37.47 & L.P. \\
\hline 3 & $2 / 23 / 95$ & Pine Ridge & & 7.23 & L.P. \\
\hline 4 & $2 / 23 / 95$ & LLWDF & Larry Cox/LLWDF & 20.96 & L.P., B.R. \\
\hline 5 & $3 / 4 / 95$ & Pine Ridge $N$ of LLDWF & & 13.57 & L.P. \\
\hline 6 & $3 / 9 / 95$ & NA36 & & 4.6 & L.P. \\
\hline 7 & $3 / 10 / 95$ & Walker Branch & & $\overline{4.02}$ & L.P. \\
\hline 8 & $3 / 12 / 95$ & K-25 Beech-Laurel Area & & $\overline{2.5}$ & L.P. \\
\hline 9 & $3 / 12 / 95$ & PRA-D (S of Dyllis Rd) & & 3.87 & L.P. \\
\hline 10 & $3 / 12 / 95$ & W of PRA-D & & 16.52 & L.P. \\
\hline 11 & $3 / 15 / 95$ & Pine Ridge (E of Bear Creek Gap) & & 2.54 & L.P. \\
\hline 12 & $3 / 15 / 95$ & Pine Ridge W of Hwy 95 & & 13.73 & L.P. \\
\hline 13 & $3 / 17 / 95$ & W end of Pine Ridge & & 21.65 & L.P. \\
\hline 14 & $3 / 18 / 95$ & Clinch River shore $N$ of Bridge & & 0.78 & L.P. \\
\hline 15 & $3 / 18 / 95$ & RA8 & & 2.94 & L.P. \\
\hline 16 & $3 / 21 / 95$ & $\mathrm{NA20}$ & & 2.79 & L.P. \\
\hline 17 & $3 / 21 / 95$ & Barrens W of Herrel Rd & & 4.18 & L.P. \\
\hline 18 & $3 / 21 / 95$ & McKinney Ridge & & 4.24 & L.P. \\
\hline 19 & $3 / 21 / 95$ & Black Oak Ridge E of Poplar Creek & & 7.4 & L.P. \\
\hline 20 & $3 / 24 / 95$ & Bottom along MeNew Hollow Rd & & 1.76 & L.P. \\
\hline 21 & $3 / 24 / 95$ & Pine Ridge W of Gum Hollow Rd & & 17.43 & L.P. \\
\hline$\overline{22}$ & $3 / 25 / 95$ & Area along Old Bethel Valley Rd & & 2.46 & L.P. \\
\hline 23 & $3 / 25 / 95$ & ROW along Old Bethel Valley Rd & & 5.05 & L.P. \\
\hline 24 & $3 / 26 / 95$ & NAl Mid-section & & 0.44 & L.P. \\
\hline 25 & $3 / 26 / 95$ & NAI Disturbed Area & & 0.5 & L.P. \\
\hline 26 & $3 / 26 / 95$ & NAl Rocky Slopes & & 0.93 & L.P. \\
\hline 27 & $3 / 26 / 95$ & NA1 Low Areas (N) & & 1.09 & L.P. \\
\hline 28 & $3 / 26 / 95$ & NAI ROW Barren and S & & 2.89 & L.P. \\
\hline 29 & $3 / 28 / 95$ & NA35 & & 5.11 & L.P. \\
\hline 30 & $3 / 29 / 95$ & NA18 & & 23.07 & L.P. \\
\hline 31 & $3 / 31 / 95$ & SA-A (Shepard Cemetary Area) & & 11.24 & L.P. \\
\hline 32 & $4 / 7 / 95$ & $\mathrm{NA23}$ & & 6.67 & L.P. \\
\hline 33 & $4 / 8 / 95$ & W of Mt Vemon Rd & & 9.94 & L.P. \\
\hline 34 & $4 / 8 / 95$ & Walker Branch & & 47.37 & L.P. \\
\hline 35 & $4 / 18 / 95$ & NA41 & & 2.7 & L.P. \\
\hline
\end{tabular}


Table 2. (continued)

\begin{tabular}{|c|c|c|c|c|c|c|}
\hline METHOD & RECORDS & $\begin{array}{l}\text { T\&E } \\
\text { OBSERVED }\end{array}$ & $\begin{array}{l}\text { T\&E } \\
\text { SITE } \\
\text { LIST }\end{array}$ & $\begin{array}{l}\text { LANDSCAPE } \\
\text { ELEMENTS }\end{array}$ & COMMUNITIES & COMMENTS \\
\hline & & & & & & \\
\hline$E$ & $\mathrm{~g}$ & & & & $\mathrm{Pp}, \mathrm{Xh}, \mathrm{Mh}, \mathrm{Bu}$ & unidentified mint \\
\hline $\mathbf{E}$ & $\mathrm{g}$ & & & We, Or, Op, Wr & $\mathrm{Ba}, \mathrm{Pp}, \mathrm{Xh}, \mathrm{Mh}, \mathrm{Bu}$ & \\
\hline $\bar{E}$ & $g^{-\cdots}$ & & & & $\mathrm{Xh}, \mathrm{Mh}$ & search for sweet pinesap \\
\hline S & $g, r$ & & & Op, We & Xh, Mh, Mo & potential construction site \\
\hline $\bar{E}$ & $\mathrm{~g}$ & & & & $\mathrm{Mx}, \mathrm{Mh}, \mathrm{Xh}$ & search for sweet pinesap \\
\hline $\bar{E}$ & $\mathrm{~g}$ & & LC & We & $\mathrm{Mh}$ & unknown lily-like plant \\
\hline$E$ & $g$ & & & We & $\mathrm{Mh}, \mathrm{Xh}$ & search for sweet pinesap \\
\hline$E$ & $\mathrm{~g}$ & & & & Mh & $\begin{array}{l}\text { rare community: beech- } \\
\text { laurel }\end{array}$ \\
\hline $\bar{E}$ & $\mathrm{~g}$ & & & & $\mathrm{~Np}, \mathrm{Xh}$ & search for sweet pinesap \\
\hline$E$ & $\bar{g}$ & & & & $\mathrm{~Np}, \mathrm{Mh}, \mathrm{Xh}$ & search for sweet pinesap \\
\hline$E$ & $\mathbf{g}$ & & & $W_{r}$ & $\mathrm{Xh}$ & $\begin{array}{l}\text { vouchered lady's tresses } \\
\text { fem }\end{array}$ \\
\hline$E$ & $\mathrm{~g}$ & & & We & $\mathrm{Xh}, \mathrm{Mh}$ & $\begin{array}{l}\text { unknown orchid not yet } \\
\text { evident }\end{array}$ \\
\hline$E$ & $g$ & & & & $\mathrm{Xh}, \mathrm{Mh}, \mathrm{Np}$ & search for sweet pinesap \\
\hline $\mathrm{E}$ & $\mathbf{g}$ & & & & Mh & $\begin{array}{l}\text { used low water to search } \\
\text { bank }\end{array}$ \\
\hline$E$ & $g$ & & & $\mathrm{Or}, \mathrm{Op}$ & $\mathrm{Ba}, \mathrm{Xh}$ & \\
\hline$E$ & $\mathrm{~g}$ & & $\mathrm{Ap}$ & $\mathrm{Cl}$ & Mh & \\
\hline$E$ & $g$ & & & Or, Op & $\mathrm{Ba}, \mathrm{Xh} . \mathrm{Th}$ & search for winter annuals \\
\hline$E$ & $g$ & & & $\mathrm{Cl}, \mathrm{Mf}$ & $\mathrm{Mh}, \mathrm{He}$ & search for sweet pinesap \\
\hline$E$ & $\mathrm{~g}$ & & & & $\mathrm{Xh}, \mathrm{Mx}$ & search for sweet pinesap \\
\hline $\bar{E}$ & $\mathrm{~g}$ & & & & $\mathrm{Bh}$ & \\
\hline$E$ & $g$ & & & $\mathrm{Mf}$ & $\mathrm{Xh}, \mathrm{Mh}$ & search for sweet pinesap \\
\hline$E$ & $\underline{g}$ & & & & Th & search for winter annuals \\
\hline$E$ & $g$ & & & Op & Mo & search for winter annuals \\
\hline$E$ & $\mathrm{~g}$ & & & We & Th & \\
\hline$E$ & $g$ & & & Op & Th & search for winter annuals \\
\hline $\bar{E}$ & $\mathrm{~g}$ & & $\begin{array}{l}\mathrm{Ap}, \\
\mathrm{Rp} \\
\end{array}$ & $\mathrm{Or}, \mathrm{Cl}, \mathrm{Op}$ & $\mathrm{Ba}, \mathrm{Xh}$ & search for winter annuals \\
\hline$E$ & $g$ & & & We & $\mathrm{Bh}, \mathrm{Ma}$ & \\
\hline $\bar{E}$ & $g$ & & & $\mathrm{Ba}, \mathrm{Or}, \mathrm{We}$ & $\mathrm{Bu}, \mathrm{Bh}$ & search for winter annuals \\
\hline $\bar{E}$ & $\mathrm{~g}$ & & $\begin{array}{l}\text { De, } \\
\text { Le }\end{array}$ & $\mathrm{Or}, \mathrm{Op}, \mathrm{We}$ & $\mathrm{Np}, \mathrm{Pp}, \mathrm{Bh}, \mathrm{Xh}, \mathrm{Ba}$ & winter annual search \\
\hline$E$ & $g$ & Sc & Sc & $\mathrm{Cl}, \mathrm{W}_{\mathrm{r}}$ & $\mathrm{Mh}, \mathrm{Xh}$ & \\
\hline$E$ & $\cong$ & & & Mf & $\mathrm{Mh}, \mathrm{Np}$ & \\
\hline$E$ & $g$ & Sc. (Cr?) & Sc & $\mathrm{Cl}, \mathrm{Mf}$ & $\mathrm{Mh}$ & \\
\hline$E$ & $g$ & & & Or, Op & $\mathrm{Ba} . \mathrm{Mh}, \mathrm{Bh}$ & \\
\hline$E$ & $\mathrm{~g}$ & & & We & $\mathrm{Mh}$ & \\
\hline $\mathrm{E}$ & $g^{-}$ & $\mathrm{Cv}$ & $\mathrm{Cr}$ & Wr. Mf & $\mathrm{Mh}$ & $\cdot$ \\
\hline
\end{tabular}


Table 2. (continued)

\begin{tabular}{|c|c|c|c|c|c|}
\hline INDEX & DATE & SITE & REQUEST & ACRES & INVESTIGATOR \\
\hline 36 & $4 / 22 / 95$ & NA20 & & 2.19 & L.P. \\
\hline 37 & $4 / 22 / 95$ & Mckinney Ridge & & 14.66 & L.P. \\
\hline 38 & $4 / 25 / 95$ & Walker Branch & & 10.87 & L.P. \\
\hline 39 & $4 / 27 / 95$ & NA43 & & 18.48 & L.P. \\
\hline 40 & $5 / 4 / 95$ & Flashlight Cave Area & & 1.6 & L.P. \\
\hline 41 & $5 / 4 / 95$ & RA21 and Vicinity & & 16.65 & L.P. \\
\hline 42 & $5 / 5 / 95$ & W End of NA 41 & & 13.7 & LP \\
\hline 43 & $5 / 6 / 95$ & NA 18 and More & & 34.99 & L.P. \\
\hline 44 & $5 / 7 / 95$ & $\mathrm{NA2}$ & & 5.61 & L.P. \\
\hline 45 & $5 / 8 / 95$ & W of Scarboro Rd & & 2.27 & L.P. \\
\hline 46 & $5 / 8 / 95$ & N of Rogers Quarty & & 2.45 & L.P. \\
\hline 47 & $5 / 12 / 95$ & Haw Ridge SE of Scarboro Facility & & 10.3 & L.P. \\
\hline 48 & $5 / 13 / 95$ & NAl Open Slopes & - & 0.95 & L.P. \\
\hline 49 & $5 / 13 / 95$ & NAI ROW Barren & & 2.04 & L.P. \\
\hline 50 & $5 / 17 / 95$ & K-25 Filuation Plant Pond & & 0.7 & L.P. \\
\hline 51 & $5 / 17 / 95$ & NA27 & & 0.71 & L.P. \\
\hline 52 & $5 / 17 / 95$ & New Platanthera flava Site & & 3.82 & L.P. \\
\hline 53 & $5 / 21 / 95$ & S of Robotics Lab & & 12.3 & L.P. \\
\hline 54 & $5 / 25 / 95$ & SA-A (SW end) & & 3.34 & L.P. \\
\hline 55 & $5 / 25 / 95$ & SA-A (E end) & & 8.05 & L.P. \\
\hline 56 & $5 / 27 / 95$ & ROW S of Bear Creek & & 0.46 & L.P. \\
\hline 57 & $5 / 27 / 95$ & NA2 & & 12.26 & L.P. \\
\hline 58 & $5 / 28 / 95$ & S of ROW and N of NA2 & & 10.4 & L.P. \\
\hline 59 & $6 / 4 / 95$ & W End of NA4I & & 8.97 & L.P. \\
\hline 60 & $6 / 8 / 95$ & NA2 S Extension & & 10.45 & L.P. \\
\hline 61 & $6 / 10 / 95$ & ROW N of NA2 & & 16.07 & L.P. \\
\hline 62 & $6 / 14 / 95$ & Upper Ish Creek Wetland (1) & & 3.8 & L.P. \\
\hline 63 & $6 / 14 / 95$ & W Trans Chestnut Ridge ROW & & 4.99 & L.P. \\
\hline 64 & $6 / 19 / 95$ & Melton Shore & & 57.56 & L.P. \\
\hline 65 & $6 / 21 / 95$ & Grassy Creek Pumping Station and $N$ & & 1.43 & L.P. \\
\hline 66 & $6 / 21 / 95$ & N of K-25 Filtration Plant Pond & & 2.21 & L.P. \\
\hline 67 & $6 / 21 / 95$ & SE of Gallaher Bridge Wetiand & & 4.45 & L.P. \\
\hline 68 & $6 / 22 / 95$ & Haw Ridge W of Solway Bridge & & 20.42 & L.P. \\
\hline 69 & $6 / 23 / 95$ & NA2 & & 0.24 & L.P. \\
\hline 70 & $6 / 23 / 95$ & Outcrop Area Near NA2 & & 6.09 & L.P. \\
\hline 71 & $6 / 24 / 95$ & ROW at Gum Hollow Rd (W) & . & 0.34 & L.P. \\
\hline
\end{tabular}




\section{A-9}

Table 2. (continued)

\begin{tabular}{|c|c|c|c|c|c|c|}
\hline METHOD & RECORDS & $\begin{array}{l}\text { T\&E } \\
\text { OBSERVED }\end{array}$ & $\begin{array}{l}\text { T\&E } \\
\text { SITE } \\
\text { LIST }\end{array}$ & $\begin{array}{l}\text { LANDSCAPE } \\
\text { ELEMENTS }\end{array}$ & COMMUNITIES & COMMENTS \\
\hline $\bar{E}$ & $\bar{g}$ & & $\overline{A p}$ & $\overline{C l}, \mathrm{~W}_{\mathrm{r}}$ & $\overline{\mathrm{Mh}}$ & \\
\hline $\bar{E}$ & $g$ & $A p_{1}, C v$ & & $\mathrm{Cl}, \mathrm{Wr}_{\mathrm{r}}$ & $\mathrm{Mh}$ & \\
\hline $\bar{E}$ & $g$ & & & We & Mh & \\
\hline $\bar{E}$ & $\mathrm{~g}$ & & $\overline{D e}$ & $\mathrm{Cl}, \mathrm{Op}, \mathrm{Mf}$ & $\mathrm{Mh}$ & \\
\hline $\bar{E}$ & $g$ & & & $\overline{W r}$ & Mh & \\
\hline$E$ & g & & & We & $\mathrm{Op}, \mathrm{Mh}$ & \\
\hline $\bar{E}$ & $\mathrm{~g}$ & $\mathrm{Cv}, \mathrm{Pq}$ & $\overline{C v}$ & $\mathrm{Mf}$ & $\mathrm{Xh}, \mathrm{Mh}$ & \\
\hline $\mathrm{E}$ & $\bar{g}$ & $\overline{S c}$ & $\overline{S c}$ & $\mathrm{Cl}, \mathrm{Mf}$ & Mh & \\
\hline$E$ & $\mathrm{~g}$ & & $\begin{array}{l}\mathrm{Hc}, \\
\mathrm{Lc}\end{array}$ & $\mathrm{Wr}, \mathrm{Mf}$ & $\mathrm{Mh}$ & \\
\hline $\mathbf{E}$ & $\bar{g}$ & & & $\mathrm{Wr}$ & $\mathrm{Ha}$ & \\
\hline $\bar{E}$ & $g$ & & & We & Th, Ma & \\
\hline $\bar{E}$ & $\mathrm{~g}$ & & & & $\mathrm{Xh}, \mathrm{Mh}$ & \\
\hline $\bar{E}$ & $g$ & $R p$ & $\overline{A p}$ & Or, Op & $\mathrm{Xh}, \mathrm{Ba}$ & \\
\hline$E$ & g & & & Op & $\mathrm{Bu}, \mathrm{Ba}$ & \\
\hline $\bar{E}$ & $\mathrm{~g}$ & Sl. Ap & Ap & We & Bh, Th & \\
\hline $\bar{E}$ & $\mathrm{~g}$ & & $\mathrm{Pp}$ & we & Mo & \\
\hline $\bar{E}$ & $g$ & $\overline{\mathrm{Pf}}$ & & We & $\mathrm{Bh}$ & \\
\hline $\bar{E}$ & $g$ & & & $\mathrm{We}, \mathrm{Cl}$ & $\overline{M h}$ & \\
\hline $\bar{E}$ & $\bar{g}$ & & & $\mathrm{Mf}$ & $\mathrm{Mh}$ & \\
\hline $\bar{E}$ & $\mathrm{~g}$ & & & $\mathrm{Mf}$ & $\overline{M h}$ & \\
\hline $\bar{E}$ & $\bar{g}$ & & & We, Op & Mh & \\
\hline $\bar{E}$ & $\mathrm{~g}$ & $\mathrm{Hc}$ & $\begin{array}{l}\mathrm{Hc}, \\
\mathrm{Lc}\end{array}$ & $\mathrm{Mf}$ & $\mathrm{Mh}$ & \\
\hline $\bar{E}$ & $\mathrm{~g}$ & & & $W_{r}$ & $\mathrm{Mh}$ & \\
\hline $\bar{E}$ & $\mathrm{~g}$ & $\mathrm{Cr}_{\mathrm{V}}$ & $\mathrm{Cv}$ & $\mathrm{Mf}$ & $\mathrm{Mh}$ & \\
\hline $\bar{E}$ & $\mathrm{~g}, \mathrm{~h}$ & Lc & & We & Mh, Xh & $\begin{array}{l}\text { unknown Juncus (later } \\
\text { identified) }\end{array}$ \\
\hline $\bar{E}$ & $\bar{g}$ & & & & $\mathrm{Bu}$ & \\
\hline $\bar{E}$ & $\bar{g}$ & & & We & $\mathrm{Bh}$ & \\
\hline $\bar{E}$ & $\bar{g}$ & & & Op & $\mathrm{Bu}$ & \\
\hline $\bar{E}$ & $g$ & $\mathrm{Ap}, \mathrm{Sc}$ & $\begin{array}{l}\mathrm{Ap}, \\
\mathrm{Sc}, \\
\mathrm{Cg}_{\mathrm{g}}\end{array}$ & $\mathrm{Cl}, \mathrm{Mf}$ & $\mathrm{Mh}$ & \\
\hline $\bar{E}$ & $g$ & & & We & $\mathrm{Mh}$ & \\
\hline $\bar{E}$ & $g$ & & & Op, We & $\mathrm{Bu}$ & \\
\hline $\bar{E}$ & $g . h$ & & & We & $\mathrm{Bu}, \mathrm{Pp}$ & $\begin{array}{l}\text { possible specimen of Carex } \\
\text { echinata }\end{array}$ \\
\hline $\bar{E}$ & $g$ & & & $\mathrm{Wr}, \mathrm{Mf}$ & $\mathrm{Mh}$ & \\
\hline $\bar{E}$ & $\underline{g}$ & & $\begin{array}{l}\text { Lc, } \\
\text { Hc }\end{array}$ & Mf & $\overline{M h}$ & \\
\hline$E$ & $g$ & & & $\overline{W_{r}}$ & $\overline{\mathrm{Mh}}$ & \\
\hline $\bar{E}$ & g - & & & Op. we & Mo & \\
\hline
\end{tabular}


Table 2. (continued)

\begin{tabular}{|c|c|c|c|c|c|}
\hline INDEX & DATE & SITE & REQUEST & ACRES & INVESTIGATOR \\
\hline 72 & $6 / 24 / 95$ & NAl Open Slopes & & 1.12 & L.P. \\
\hline 73 & $6 / 24 / 95$ & NAl ROW Barren & & 1.72 & L.P. \\
\hline 74 & $6 / 25 / 95$ & Chestnut Ridge Substation Wetland & & 0.3 & L.P. \\
\hline 75 & $6 / 25 / 95$ & Chestnut Ridge ROWs & & 16.56 & L.P. \\
\hline 76 & $6 / 26 / 95$ & A Pine Ridge Stream & & 23.01 & L.P. \\
\hline 77 & $6 / 28 / 95$ & $\begin{array}{l}\text { Wet ditch next to road near EFPC } \\
\text { gaging station }\end{array}$ & Parcel ED-1 & 0.59 & D.A. \\
\hline 78 & $6 / 28 / 95$ & Spring near Lambert's Quarry & Parcel ED-1 & 0.66 & D.A. \\
\hline 79 & $6 / 28 / 95$ & Lower EFPC floodplain & Parcel ED-1 & 0.92 & D.A. \\
\hline 80 & $6 / 28 / 95$ & East of Herrel Rd & Parcel ED-1 & 1.89 & D.A. \\
\hline 81 & $6 / 28 / 95$ & RA3a & Parcel ED-1 & 1.94 & D.A. \\
\hline 82 & $6 / 28 / 95$ & East Quarry Rd, tributary to EFPC & Parcel ED-1 & 3.04 & D.A. \\
\hline 83 & $6 / 28 / 95$ & North of Bull Bluff Road & & 7.54 & DA. \\
\hline 84 & $6 / 29 / 95$ & Lower EFPC Floodplain & Parcel ED-1 & 14.06 & D.A., B.R. \\
\hline 85 & $6 / 30 / 95$ & RA2I & & 2.82 & L.P. \\
\hline 86 & $7 / 10 / 95$ & Beaver Pond EFPC & Parcel ED-1 & 0.27 & L.P. \\
\hline 87 & $7 / 10 / 95$ & Henrel Rd Barrens & Parcel ED-1 & 0.88 & L.P. \\
\hline 88 & $7 / 12 / 95$ & Lambert's Quarry & Parcel ED-1 & 4.21 & L.P. \\
\hline 89 & $7 / 12 / 95$ & EFPC & Parcel ED-1 & 4.24 & L.P. \\
\hline 90 & $7 / 13 / 95$ & K-25 Old Barracks Site & & 3.16 & L.P. \\
\hline 91 & $7 / 13 / 95$ & Herrel Rd area ( $\mathrm{S}$ area) & Parcel ED-1 & 31.99 & R.C. \\
\hline 92 & $7 / 14 / 95$ & Lower EFPC & Parcel ED-1 & 44.35 & D.A., B.R. \\
\hline 93 & $7 / 15 / 95$ & Hydrastis canadensis site EFPC & Parcel ED-1 & 0.34 & L.P. \\
\hline 94 & $7 / 15 / 95$ & Beech-Maple Forest & Parcel ED-1 & 5.37 & L.P. \\
\hline 95 & $7 / 15 / 95$ & EFPC & Parcel ED-1 & 7.08 & L.P. \\
\hline 96 & $7 / 16 / 95$ & Stream E of Lambert Quarry & Parcel ED-1 & 2.16 & L.P. \\
\hline 97 & $7 / 16 / 95$ & SE End of EFPC & Parcel ED-1 & 7.52 & L.P. \\
\hline 98 & $7 / 18 / 95$ & SW End of EFPC & Parcel ED-1 & 1.95 & LP \\
\hline 99 & $7 / 18 / 95$ & NA27 & & 6.51 & L.P. \\
\hline 100 & $7 / 18 / 95$ & Herrel Rd area (N area) & Parcel ED-1 & 18.76 & R.C. \\
\hline 101 & $7 / 19 / 95$ & Lily Bloom Area (NA22) & & 0.99 & R.C. \\
\hline 102 & $7 / 19 / 95$ & NW End of EFPC & Parcel ED-1 & 2.53 & LP \\
\hline 103 & $7 / 20 / 95$ & Clearcut $S$ of EFPC Rd. & Parcel ED-1 & 2.89 & R.C. \\
\hline 104 & $7 / 20 / 95$ & Possible Plantation Covered Barren & Parcel ED-1 & 2.98 & R.C. \\
\hline
\end{tabular}




\section{A-11}

Table 2. (continued)

\begin{tabular}{|c|c|c|c|c|c|c|}
\hline METHOD & RECORDS & $\begin{array}{l}\text { T\&E } \\
\text { OBSERVED }\end{array}$ & $\begin{array}{l}\text { T\&E } \\
\text { SITE } \\
\text { LIST }\end{array}$ & $\begin{array}{l}\text { LANDSCAPE } \\
\text { ELEMENTS }\end{array}$ & COMMUNITIES & COMMENTS \\
\hline$E$ & $\mathbf{g}$ & & $\begin{array}{l}\text { Rp, } \\
\text { Ap }\end{array}$ & Or, Op & $\mathrm{Xh}, \mathrm{Ba}$ & \\
\hline E & $\mathbf{g}$ & & & Or, Op & $\mathrm{Bu}, \mathrm{Ba}$ & \\
\hline $\mathrm{E}$ & $\mathrm{g}$ & & & We & Mo & \\
\hline$E$ & $g$ & & & Op & Mo, Bu & \\
\hline $\mathrm{E}$ & g & & & We & $\mathrm{Mh}$ & \\
\hline E & g. : & & & & clearcut & confusing Typha specimens \\
\hline$E$ & g,: : & & & We & $\mathrm{Bh}$ & $\begin{array}{l}\text { wetland around spring } \\
\text { w/saprophytic muck. } \\
\text { sweetflag \& sycamore }\end{array}$ \\
\hline$E$ & $g, r$ & & & We, & $\mathrm{Bh}$ & \\
\hline$E$ & g, r & & & Rs & clearcut, Mh & $\begin{array}{l}\text { the sink is a southeastem } \\
\text { shrew site }\end{array}$ \\
\hline$E$ & g. $r$ & & & We & $\mathrm{Bh}, \mathrm{Cn}$ & \\
\hline$E$ & g. 1 & & & We & Mh, Bh, clearcut & \\
\hline $\bar{M}$ & p.g & Lc & Le & Op & $\mathrm{Mh}, \mathrm{Mo}$ & Lc in bloom \\
\hline $\mathrm{E}$ & $g, 5$ & & & We & $\mathrm{Bh}, \mathrm{Ma}, \mathrm{Cn}$ & critical wetland, springs \\
\hline $\bar{E}$ & $\bar{g}$ & & & We & $\mathrm{Mh}$ & \\
\hline $\mathrm{E}$ & $8, r$ & & & We & $\mathrm{Bh}$ & \\
\hline$E$ & $g, r$ & & & Or, Op & $\mathrm{Xh}, \mathrm{Ba}$ & \\
\hline $\mathrm{E}$ & g.h.r & $(\mathrm{Rc})$ & & $\mathrm{We}, \mathrm{Cl}$ & $\mathrm{xh}$ & $\begin{array}{l}\text { found Rhynchospora } \\
\text { colorata (new for TN) }\end{array}$ \\
\hline $\mathrm{E}$ & g. $r$ & & & $\mathrm{Cl}$ & $\mathrm{Mh}$ & \\
\hline$E$ & $\mathrm{~g}$ & & & & Th & \\
\hline$E$ & g. $r$ & & & Or, Op & $\mathrm{Ba}, \mathrm{Xh}, \mathrm{Mh}$ & \\
\hline $\bar{E}$ & $g, r$ & & & We, $\mathrm{Cl}$ & $\begin{array}{l}\text { Bh, Mh, Th, Cn, } \\
\text { Ma, Np, Pp, Wp, } \\
\text { ciearcut }\end{array}$ & $\begin{array}{l}\text { (by canoe) cliffs/outcrops } \\
\text { not evident from topo map }\end{array}$ \\
\hline$E$ & S. $r$ & $\mathrm{Hc}$ & & & Mh & \\
\hline$E$ & g. $r$ & & & $\mathrm{Mf}$ & Mh. Bm & beech-maple is unusual . \\
\hline$E$ & $g, r$ & & & $\mathrm{Cl}$ & Mh & \\
\hline $\bar{E}$ & g. $r$ & & & We & Mh & \\
\hline$E$ & g. $r$ & & & & Mh & \\
\hline$E$ & g. $r$ & & & & Mh & unidentified mint \\
\hline$E$ & $\mathrm{~g}$ & $\mathrm{Pp}$ & $\mathbf{P p}$ & We & Mo & \\
\hline $\bar{E}$ & g. $r$ & $\mathrm{Hc}$ & $\mathrm{Hc}$ & $\mathrm{Mf}$ & $\mathrm{Xh} . \mathrm{Mh}$ & $\begin{array}{l}\text { drainage eniers rocky near } \\
\text { mature forest }\end{array}$ \\
\hline$M$ & g. $r$ & Lc & Lc & We & Mo & $\begin{array}{l}\text { nr seed formed following } \\
\text { blooming }\end{array}$ \\
\hline$E$ & g. $r$ & & & & Mh & \\
\hline E & $g, r$ & & & & clearcut & \\
\hline $\bar{E}$ & $9 ;$ & . & & & $\mathrm{Pp}$ & $\begin{array}{l}\text { no distinctive barren } \\
\text { vegetation found }\end{array}$ \\
\hline
\end{tabular}


Table 2. (continued)

\begin{tabular}{|c|c|c|c|c|c|}
\hline INDEX & DATE & SITE & REQUEST & ACRES & INVESTIGATOR \\
\hline 105 & $7 / 20 / 95$ & Lambert Quarry Pond (Canoe) & Parcel ED-1 & 4.24 & L.P., D.A. \\
\hline 106 & $7 / 20 / 95$ & Bear Cr near EFPC & Parcel ED-1 & 25.35 & R.C. \\
\hline 107 & $7 / 21 / 95$ & Upper Ish Wetland (2) & & 6.52 & L.P. \\
\hline 108 & $7 / 23 / 95$ & ROW N of NA37 & & 0.38 & LP \\
\hline 109 & $7 / 23 / 95$ & NA37 & & 1.04 & LP \\
\hline 110 & $7 / 23 / 95$ & W End Fence-to-bound Strip B. O. R. & & 15.65 & LP \\
\hline 111 & $7 / 30 / 95$ & Chestnut Ridge SDZ (E Bound.) & & 3.62 & L.F. \\
\hline 112 & $7 / 30 / 95$ & Beaver Pond along Hwy 95 & & 4.26 & L.P. \\
\hline 113 & $8 / 1 / 95$ & Parcel ED-1 NE Boundary & Parcel ED-1 & 10.09 & L.P. \\
\hline 114 & $8 / 2 / 95$ & NA46 and $N$ & & 9.6 & L.P. \\
\hline 115 & $8 / 3 / 95$ & NA36 & & $3.57-$ & L.P. \\
\hline 116 & $8 / 4 / 95$ & TSR (stream area) & & 4.07 & L.P. \\
\hline 117 & $8 / 4 / 95$ & TSR (E end) & & 30.9 & L.P. \\
\hline 118 & $8 / 6 / 95$ & NAl Open Slopes & & 0.57 & L.P. \\
\hline 119 & $8 / 6 / 95$ & NAl ROW Barren & & 1.54 & L.P. \\
\hline 120 & $8 / 9 / 95$ & NA2 & & 41.82 & L.P. \\
\hline 121 & $8 / 10 / 95$ & NA27 area & & 5.09 & L.P. \\
\hline 122 & $8 / 10 / 95$ & RA13 and Vicinity (TSR) & & 45.08 & L.P. \\
\hline 123 & $8 / 12 / 95$ & W of Lambert Quarry & & 5.23 & L.P. \\
\hline 124 & $8 / 12 / 95$ & N of Lambert Quarty & & 30.47 & L.P. \\
\hline 125 & $8 / 14 / 95$ & S of East Fork Ridge & & 12.32 & L.P. \\
\hline 126 & $8 / 15 / 95$ & Leatherwood Bluffs (NA 41) & & 3.39 & L.P. \\
\hline 127 & $8 / 17 / 95$ & Springs between Bethel Valley Rds & & 2.09 & L.P. \\
\hline 128 & $8 / 17 / 95$ & N of Roger Quarry & & 2.27 & L.P. \\
\hline 129 & $8 / 17 / 95$ & W of Deer Checking Staation & & 11.9 & L.P. \\
\hline 130 & $8 / 18 / 95$ & W Walker Branch & & 9.83 & L.P. \\
\hline 131 & $8 / 18 / 95$ & ROW W of Mt. Vernon Rd & & 19.61 & L.P. \\
\hline 132 & $8 / 23 / 95$ & NA7 & & 22.4 & L.P. \\
\hline 133 & $8 / 24 / 95$ & Wetlands/Springs at Bear $\mathrm{Cr}, 95 \mathrm{Jct}$ & & 4.31 & L.P. \\
\hline 134 & $8 / 24 / 95$ & Chestnut Ridge $\mathrm{E}$ of HWY 95 & & 10.39 & L.P. \\
\hline 135 & $8 / 25 / 95$ & RA12 & & 18.82 & L.P. \\
\hline 136 & $8 / 31 / 95$ & Chestnut Ridge ROWs & & 5.46 & L.P. \\
\hline 137 & 9/1/95 & A Bethel Valley Pond & & 0.42 & L.P. \\
\hline 138 & 9/1/95 & Pond W of Deer Checking Station & & 0.71 & L.P. \\
\hline 139 & 9/1/95 & Fly Ash Area & & 5.51 & L.P. \\
\hline 140 & $9 / 5 / 95$ & Pond N of Roger's Quarty & & 2.83 & L.P. \\
\hline
\end{tabular}


Table 2. (continued)

\begin{tabular}{|c|c|c|c|c|c|c|}
\hline METHOD & RECORDS & $\begin{array}{l}\text { T\&E } \\
\text { OBSERVED }\end{array}$ & $\begin{array}{l}\text { T\&E } \\
\text { SITE } \\
\text { LISTT }\end{array}$ & $\begin{array}{l}\text { LANDSCAPE } \\
\text { ELEMENTS }\end{array}$ & COMMUNITIES & COMMENTS \\
\hline$E$ & $8, r$ & $\mathrm{Rc}$ & $\mathrm{Rc}$ & $\mathrm{We}, \mathrm{Cl}$ & $\mathrm{Xh}$ & \\
\hline$E$ & $\mathrm{~g}, \mathrm{r}$ & & & & $\mathrm{Mh}$ & \\
\hline$E$ & $g$ & & & we & $\mathrm{Mh}$ & \\
\hline $\bar{E}$ & $g$ & & & Op, Or, Op & $\mathrm{Bu}, \mathrm{Ba}$ & \\
\hline$E$ & g & & $\begin{array}{l}\text { Ap, } \\
D r\end{array}$ & $\mathrm{Cl}, \mathrm{Or}, \mathrm{W}_{\mathrm{r}, \mathrm{Op}}$ & $\mathrm{Mh}, \mathrm{Xh}, \mathrm{Ba}$ & 2 vouchers \\
\hline$E$ & $g$ & $\mathrm{Cv}$ & & Mf & $\mathrm{Mh}, \mathrm{Th}$ & \\
\hline$E$ & $g$ & & & Op & Mo, Mh & \\
\hline$E$ & $\mathrm{~g}$ & & & We & Mh & \\
\hline$E$ & g. $r$ & & & Mf & $\mathrm{Mh}, \mathrm{Np}$ & \\
\hline $\bar{E}$ & $\bar{g}$ & $\mathrm{Cr}_{\mathrm{V}}$ & & Mf & $\mathrm{Xh}, \mathrm{Np}, \mathrm{Mh}$ & \\
\hline $\mathbf{E}$ & $\mathrm{g}$ & & & Mf, Wr, We & $\mathrm{Mh}$ & found Isoetes \\
\hline $\bar{E}$ & $g$ & & & & $\mathrm{Mh}, \mathrm{Xh}$ & \\
\hline $\mathrm{E}$ & $\mathrm{g}$ & & & & Mh, Xh & \\
\hline$E$ & $\mathbf{g}$ & & $\begin{array}{l}\mathrm{Rp}, \\
\mathrm{Ap}\end{array}$ & Or, Op & $\mathrm{Xh}, \mathrm{Ba}$ & checked Rp \\
\hline$E$ & $\mathrm{~g}$ & & & Or, Op & $\mathrm{Bu}, \mathrm{Ba}$ & \\
\hline $\bar{E}$ & $\bar{g}$ & & & We, Wr & $\mathrm{Mh}, \mathrm{Xh}$ & \\
\hline $\bar{E}$ & $\mathbf{g}$ & & & We & $\mathrm{Mh}$ & \\
\hline E & $g$ & $\begin{array}{l}\text { (see } \\
\text { comment) }\end{array}$ & & Rs & Mh, Xh & $\begin{array}{l}\text { may have found Viola } \\
\text { tripartita var. tripartita }\end{array}$ \\
\hline$E$ & $\mathrm{~g}$ & & & We & Mh. Xh & $\begin{array}{l}\text { unknown plant in } \\
\text { sometimes wet distrurbed } \\
\text { open area }\end{array}$ \\
\hline$E$ & $\mathbf{g}$ & $\mathrm{Ca}$ & $\mathrm{Ca}$ & Mf & $\mathrm{Mh}, \mathrm{Xh}, \mathrm{Np}$ & more Ca sites \\
\hline$E$ & $g$ & & & & Mh. Xh & \\
\hline $\mathbf{E}$ & $g$ & & $\mathrm{Cv}$ & Mf, Wr & Mh & unkown mint past flowering \\
\hline $\bar{E}$ & $\mathbf{g}$ & & & We & $\mathrm{Mh}$ & \\
\hline E & $\mathrm{g}$ & & & We & Th, Ma & beaver dam \\
\hline $\mathbf{E}$ & $g$ & & & We. Op & $\mathrm{Bu}, \mathrm{Ha}$ & \\
\hline$E$ & $\mathbf{g}$ & & & Mh & $\mathrm{Mh}$ & \\
\hline $\mathbf{E}$ & $g$ & & & $O r, O p$ & $\mathrm{Bu}, \mathrm{Ba}$ & \\
\hline$E$ & $g$ & & De & Op & Mh, Xh. Bu & \\
\hline$E$ & g & & & We & Mh & \\
\hline$E$ & $g$ & & & & $\mathrm{Mh}, \mathrm{Xh}$ & \\
\hline$E$ & $\underline{g}$ & $\mathrm{Cg}_{\mathrm{g}}$ & & $\mathrm{Cl}, \mathrm{Or}$ & $\mathrm{Xh}$ & \\
\hline $\mathrm{E}$ & $\underline{g}$ & & & Op & $\mathrm{Bu}, \mathrm{Mo}$ & \\
\hline $\bar{E}$ & $\cong$ & & & We & $\mathrm{Bu}$ & unknown Sagittaria \\
\hline $\bar{E}$ & g & & & We & $\mathrm{Bu}$ & \\
\hline$E$ & g & & So & We & Th & \\
\hline $\bar{E}$ & g & & & We & $\overline{P p}$ & unknown Sagittaria found \\
\hline
\end{tabular}


A-14 .

Table 2. (continued)

\begin{tabular}{|c|c|c|c|c|c|}
\hline INDEX & $\overline{\text { DATE }}$ & SITE & REQUEST & ACRES & INVESTIGATOR \\
\hline 141 & 9/6/95 & NA36 & & 2.35 & L.P. \\
\hline 142 & 9/6/95 & ROW SW of SA-A & & 3.68 & L.P. \\
\hline 143 & 9/6/95 & ROW SW of Katie's Kitchen (E) & & 5.04 & L.P. \\
\hline 144 & 9/8/95 & N of Pine Ridge Streag & & 0.7 & L.P. \\
\hline 145 & 9/8/95 & S of Bear Cr Mowed Area (Middle) & & 2.76 & L.P. \\
\hline 146 & 9/9/95 & ROW SW of $0907(W)$ & & 27.38 & L.P. \\
\hline 147 & $9 / 12 / 95$ & RA12 & & 26.89 & L.P. \\
\hline 148 & $9 / 13 / 95$ & Robert's Branch (RA24) & & 3.71 & L.P. \\
\hline 149 & $9 / 14 / 95$ & S of Bear Cr Mowed Area (E End) & & 2.31 & L.P. \\
\hline 150 & 9/14/95 & E end of NA27 & & 2.79 & L.P. \\
\hline 151 & $9 / 14 / 95$ & NW end of NA2 & 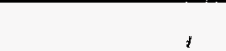 & 6.55 & L.P. \\
\hline 152 & 9/15/95 & NA43 and ROW on N Side & & 24.3 & L.P. \\
\hline 153 & $9 / 18 / 95$ & Bull Bluff Above the Cliff & & 13.65 & L.P. \\
\hline 154 & $9 / 18 / 95$ & Bull Bluff Bend & & 22.28 & L.P. \\
\hline 155 & $9 / 19 / 95$ & N End of NA23 & & 4.18 & L.P. \\
\hline 156 & $9 / 20 / 95$ & Slope Bottom NA41 & & 4.22 & L.P. \\
\hline 157 & $9 / 21 / 95$ & Chestnut Ridge ROW & & 1.85 & L.P. \\
\hline 158 & $9 / 23 / 95$ & W Bethel Valley Pond & & 2.48 & L.P. \\
\hline 159 & $9 / 25 / 95$ & Pine Ridge Gasline and Power ROW's & & 20.18 & L.P. \\
\hline 160 & $9 / 26 / 95$ & RA19 & & 1.82 & L.P. \\
\hline 161 & $9 / 26 / 95$ & Hembree Marsh & & 2.55 & L.P. \\
\hline 162 & $9 / 26 / 95$ & Red Barren E of 95 & & 4.27 & L.P. \\
\hline 163 & $9 / 27 / 95$ & Jct. $95 \&$ Bear $\operatorname{Cr}(\mathbb{N})$ & & 1.19 & L.P. \\
\hline 164 & $9 / 27 / 95$ & East Fork Ridge & & 6.69 & L.P. \\
\hline 165 & $9 / 29 / 95$ & Mckinney Ridge near Popular Creek & & 5.81 & L.P. \\
\hline 166 & $2 / 21 / 96$ & Outside Kerr Hollow Fence & & 4.36 & L.P. \\
\hline 167 & $3 / 22 / 96$ & S end of Mckinney Ridge & & 36.19 & L.P. \\
\hline 168 & $3 / 24 / 96$ & W of Hot Yard Rd & & 12.78 & L.P. \\
\hline 169 & $3 / 26 / 96$ & Chestnut Ridge (cabin road) & & 6.97 & L.P. \\
\hline 170 & $3 / 30 / 96$ & Rainy Knob & & 4.21 & L.P. \\
\hline 171 & $3 / 30 / 96$ & S of Clark Center & & 6.65 & L.P. \\
\hline 172 & $4 / 1 / 96$ & TSF southwest & & 19.12 & L.P. \\
\hline 173 & $4 / 2 / 96$ & TSF W Copper Ridge & & 1.88 & L.P. \\
\hline 174 & $4 / 2 / 96$ & TSF cave area & & 10.67 & L.P. \\
\hline 175 & $4 / 2 / 96$ & TSF including bluffs & & 27.33 & L.P. \\
\hline 176 & $4 / 3 / 96$ & Jct Poplar Cr \& EFPC & & 1.05 & L.P. \\
\hline 177 & $4 / 3 / 96$ & S of East Fork Ridge & & 7.01 & L.P. \\
\hline 178 & $4 / 3 / 96$ & $\mathrm{~N}$ of Lambert Quarry & & 20.05 & L.P. \\
\hline 179 & $4 / 10 / 96$ & TSF upper west bluffs & & 14.25 & L.P. \\
\hline
\end{tabular}




\section{A-15}

Table 2. (continued)

\begin{tabular}{|c|c|c|c|c|c|c|}
\hline METHOD & RECORDS & $\begin{array}{l}\text { T\&E } \\
\text { OBSERVED }\end{array}$ & $\begin{array}{l}\text { T\&E } \\
\text { SITE } \\
\text { LIST }\end{array}$ & $\begin{array}{l}\text { LANDSCAPE } \\
\text { ELEMENTS }\end{array}$ & COMMUNITIES & COMMENTS \\
\hline$E$ & $\mathbf{g}$ & & LC & We, Mf & $\mathrm{Mh}$ & $\begin{array}{l}\text { 3rd cluster of lily like plant } \\
\text { found but no flowers }\end{array}$ \\
\hline E & $\mathrm{g}$ & & & Op & $\mathrm{Bu}$ & \\
\hline$E$ & $\mathrm{~g}$ & & & Op, Or & $\mathrm{Ba}, \mathrm{Bu}, \mathrm{Xh}$ & \\
\hline$E$ & $\mathbf{g}$ & & & We & $\mathrm{Bh}$ & $\begin{array}{l}\text { supposed Gentian was } \\
\text { Phlox }\end{array}$ \\
\hline E & $\mathrm{g}$ & & & We & Mo & . \\
\hline$E$ & $\mathrm{~B}$ & & & Op & $\mathrm{Bu}$ & \\
\hline$E$ & $\mathrm{~g}$ & & $\mathrm{Cg}$ & $\mathrm{Cl}_{1} \mathrm{Mf}-$ & $\mathrm{Xh}, \mathrm{Mh}$ & \\
\hline$E$ & $\mathbf{g}$ & & & We & $\mathrm{Bh}$ & $\begin{array}{l}\text { new embayment wetland } \\
\text { discovered }\end{array}$ \\
\hline$E$ & $\mathrm{~g}$ & & & We & Mo & \\
\hline$E$ & $g$ & & $\mathrm{Pp}$ & We. Op & $\mathrm{Bu}, \mathrm{Mo}$ & \\
\hline $\mathrm{E}$ & $\mathrm{g}$ & $\mathrm{Hc}$ & $\mathrm{Hc}$ & Wr, Mf & Mh, Bu & $\begin{array}{l}\text { a possible } \mathrm{Cr} \text { specimen } \\
\text { apparently died back }\end{array}$ \\
\hline $\mathbf{E}$ & $\mathbf{g}$ & $\mathrm{De}$ & & $W_{r}, O_{,}, O_{p}$ & $\mathrm{Ba}, \mathrm{Xh}, \mathrm{Bu}$ & $\begin{array}{l}\text { found large new De } \\
\text { population }\end{array}$ \\
\hline E & $\mathbf{g}$ & $\mathrm{Dl}$ & DI & Wr, Rs & Mh, Xh & possible new cave entrences \\
\hline $\bar{E}$ & $g$ & & & & $\mathrm{Mh}, \mathrm{Th}, \mathrm{Ha}$ & \\
\hline$E$ & $g$ & $\mathrm{Cr}$ & & Wo, Mf & $\mathrm{Mh}, \mathrm{Xh}, \mathrm{Ba}$ & Cr presence confirmed \\
\hline$E$ & $\mathbf{g}$ & & & $\mathrm{Wr}_{\mathrm{r}, \mathrm{Cl}}$ & $\mathrm{Mh}$ & $\begin{array}{l}\text { perhaps a new species of } \\
\text { waterleaf (check in May) }\end{array}$ \\
\hline E & $\mathrm{g}, \mathrm{h}$ & & & & $\mathrm{Bu}, \mathrm{Mo}$ & $\begin{array}{l}\text { Cyperus odorata (new for } \\
\text { OR) }\end{array}$ \\
\hline$E$ & $\mathbf{g}$ & & & We & $\mathrm{Bu}$ & collected Sagittaria \\
\hline$E$ & $\mathbf{g}$ & & & Op & Bu, Mo & \\
\hline$E$ & $\mathrm{~g}$ & & & We & $\mathrm{Bh}, \mathrm{Ma}$ & \\
\hline$E$ & g & Ll.Jb & LI & We & $\mathrm{Bh}, \mathrm{Ma}$ & found new T\&Esites \\
\hline$E$ & $\mathrm{~g}$ & & & Op & $\mathrm{Ba}, \mathrm{Np}$ & \\
\hline$E$ & $\underline{g}$ & & & We & $\mathrm{Th}$ & \\
\hline E & $\underline{g}$ & & & $W_{r}$ & $\mathrm{Xh}$ & \\
\hline$E$ & $\mathrm{~g}$ & & $\mathrm{Ap}$, & We. Wr & Mh & \\
\hline$E$ & $g$ & & $\cdot$ & We & $\mathrm{La}, \mathrm{Mh}$ & \\
\hline E & $g$ & & & & Mh. Xh & pipeline to go into this area \\
\hline E & $\underline{g}$ & & & We & Mh. Pp & \\
\hline$E$ & $\underline{g}$ & & & & $\mathrm{Mh}, \mathrm{Xh}$ & \\
\hline$E$ & $\underline{\underline{g}}$ & Sc & Sc. & $\mathrm{Cl}, \mathrm{Rs}, \mathrm{Wr}$ & $\mathrm{Mh}$ & \\
\hline$E$ & g & & Le & Mf & Mh & \\
\hline$E$ & $g$ & & $\mathrm{Cg}$ & $\mathrm{Wr}_{\mathrm{r}}$ & La, Mh, Xh & \\
\hline $\mathrm{E}$ & $\underline{g}$ & & & $w_{r}$ & Hh & \\
\hline$E$ & $\underline{\underline{g}}$ & & & Rs. Or & $\mathrm{La}, \mathrm{Mh}, \mathrm{Xh}$ & \\
\hline$E$ & $\underline{\underline{g}}$ & & & $\mathrm{Wr}_{\mathrm{r}}$ & Mh. Xh & \\
\hline$E$ & $\underline{g}$ & & & Wr.We & Mh & mudflats checked \\
\hline$E$ & $\underline{g}$ & & & $\mathrm{Wr}_{\mathrm{r}}$ & Mh. Xh & \\
\hline$E$ & $\underline{g}$ & & $\mathrm{Ca}$ & Mf & Mx. Mh. Xh & \\
\hline$E$ & $\mathrm{~g}-$ & & $\mathrm{C} g$ & $W_{\tau}$ & Mh. Xh & \\
\hline
\end{tabular}


Table 2. (continued)

\begin{tabular}{|l|l|l|l|l|l|}
\hline INDEX & DATE & SITE & REQUEST & ACRES & INVESTIGATOR \\
\hline 180 & & & & \\
\hline 181 & $4 / 10 / 96$ & TSF stream & & 24.17 & L.P. \\
\hline 182 & $4 / 11 / 96$ & S slope East Fork Ridge & & 13.21 & L.P. \\
\hline 183 & $4 / 11 / 96$ & NA19 plus & & 14.61 & L.P. \\
\hline 184 & $4 / 12 / 96$ & S of Perimeter Rd & & 2.31 & L.P. \\
\hline 185 & $4 / 12 / 96$ & Chestnut Ridge Creek & & 3.61 & L.P. \\
\hline 186 & $4 / 12 / 96$ & Chestnut Ridge (cabin loop) & & 5.47 & L.P. \\
\hline 187 & $4 / 13 / 96$ & N of NA19 and some of NA19 & & 10.89 & L.P. \\
\hline 188 & $4 / 15 / 96$ & Bear Creek triangle & & 3.94 & L.P. \\
\hline 189 & $4 / 15 / 96$ & Ish Creek Branch & & 2.43 & L.P. \\
\hline 190 & $4 / 18 / 96$ & E end of NAl9 & & 15.71 & L.P. \\
\hline 191 & $4 / 18 / 96$ & NA39 & & 4.32 & L.P. \\
\hline 192 & $4 / 20 / 96$ & Upper Ish Creek & & 17 & L.P. \\
\hline 193 & $4 / 25 / 96$ & Large new I ily population & & 7.22 & L.P. \\
\hline 194 & $4 / 25 / 96$ & Bull Bluff & 5.98 & L.P. \\
\hline 195 & $4 / 29 / 96$ & S slope East Fork Ridge & & 22.52 & L.P. \\
\hline 196 & $4 / 29 / 96$ & Bear Ck. to Hot Yard Rd & & 12.16 & L.P. \\
\hline 197 & $4 / 30 / 96$ & Freels Bend & & 15.56 & L.P. \\
\hline 198 & $5 / 2 / 96$ & Inside Kerr Hollow Fence & & 23.47 & L.P. \\
\hline 199 & $5 / 2 / 96$ & E of Bearden Creek & & 4.82 & L.P. \\
\hline 200 & $5 / 6 / 96$ & Bear Creek & & 16.78 & L.P. \\
\hline 201 & $5 / 8 / 96$ & SE of Gallaher Bridge & & 6.14 & L.P. \\
\hline 202 & $5 / 9 / 96$ & Upper Chestnut Ridge Wetland & & 1 & L.P. \\
\hline 203 & $5 / 10 / 96$ & E of Bull Bluff Rd. & 6.47 & L.P. \\
\hline 204 & $5 / 18 / 96$ & Robert's Branch Wetland & & 12.86 & L.P. \\
\hline 205 & $5 / 20 / 96$ & E of 95 Copper Ridge & & 8.42 & L.P. \\
\hline 206 & $5 / 20 / 96$ & RA12 and ROW & 2.74 & L.P. \\
\hline & & & 13.11 & L.P. \\
\hline
\end{tabular}

INVESTIGATOR
L.P. $=$ Larty Pounds
D.A. $=$ Deborah Aw]
B.R. = Barbara Rosensteel

METHOD

$$
\begin{aligned}
& E=\text { exploratory } \\
& S=\text { systematic } \\
& M=\text { monitoring }
\end{aligned}
$$

\section{RECORDS}

$$
\begin{aligned}
& \mathrm{p}=\text { photograph } \\
& \mathrm{g}=\text { GIS map data } \\
& \mathbf{h}=\text { herbarium specimen } \\
& \mathrm{r}=\text { report }
\end{aligned}
$$

T\&E OBSERVED $=T \& E$ species observed during visit T\&E SITE LIST $=$ all T\&E species known from the site

\author{
Ap $=$ Aureolaria patula \\ $\mathrm{Cg}=$ Carex gravida \\ $\mathrm{Ch}=$ Carex howei \\ $\mathrm{Co}_{0}=$ Carex oxylepis var. pubescens \\ $\mathrm{Cr}=$ Cimicifuga rubifolia \\ $\mathrm{Ca}=$ Cypripedium acaule \\ $\mathrm{De}=$ Delphinum exaltatum \\ $\mathrm{DI}=$ Diervilla lonicera \\ $\mathrm{Dr}=$ Draba ramosissinia \\ En $=$ Elodea nuttallii \\ $\mathrm{Fm}=$ Fothergilla major \\ $\mathrm{Hc}=$ Hydrastis canadensis \\ $\mathrm{Jc}=$ Juglans cinerea \\ $\mathrm{Jb}=$ Juncus brachycephalus \\ Lc $=$ Lilium canadense \\ $\mathrm{Ll}=$ Liparis loeselii \\ $\mathrm{Pq}=$ Panar quinquifolius \\ $\mathrm{Pf}=$ Platanthera flava var. herbiola \\ $\mathrm{Pp}=$ Platanthera peramoena \\ $\mathrm{Pv}=$ Pycnanthemum verticillatum \\ $\mathrm{Rc}=$ Rhynchospora colorata
}


Table 2. (continued)

\begin{tabular}{|c|c|c|c|c|c|c|}
\hline METHOD & RECORDS & $\begin{array}{l}\text { T\&E } \\
\text { OBSERVED }\end{array}$ & $\begin{array}{l}\text { T\&E } \\
\text { SITE } \\
\text { LIST }\end{array}$ & $\begin{array}{l}\text { LANDSCAPE } \\
\text { ELEMENTS }\end{array}$ & COMMUNITIES & COMMENTS \\
\hline$E$ & $\varepsilon$ & & & Rs & $\mathrm{Np}, \mathrm{Mh}$ & \\
\hline$E$ & $g$ & & & $W_{r}$ & $\mathrm{Mh}, \mathrm{Xh}$ & \\
\hline $\mathbf{E}$ & $g$ & & $\mathrm{Cr}$ & Wr. We & Mh. Mx & need to cofirm $C_{r}$ site \\
\hline$E$ & $g$ & & & $\mathrm{Cl}, \mathrm{Wr}_{\mathrm{r}}$ & $\mathrm{Mh}, \mathrm{Xh}$ & \\
\hline$E$ & $g$ & & & & $\mathrm{~Np}, \mathrm{Mh}$ & checking for sweet pine sap \\
\hline$E$ & $\underline{g}$ & & & We & $\mathrm{Bh}$ & \\
\hline$E$ & $g$ & & & We & $\mathrm{Mh}, \mathrm{Xh}$ & \\
\hline$E$ & $g$ & $\mathrm{Ap}, \mathrm{Cv}, \mathrm{Pq}$ & Ap & Mf. Wr, Or & Mh. Xh & \\
\hline $\mathrm{E}$ & $g$ & & & We, Wr & $\mathrm{Mh}$ & \\
\hline$E$ & $g$ & & & We & $\mathrm{Bh}$ & excellent wetland \\
\hline$E$ & g & & Ap & Wr. Or, We & $\mathrm{Mh}, \mathrm{Xh}$ & unknown plant flagged \\
\hline$E$ & $g$ & & $\mathrm{Cv}$ & Mf & Mh, Mx & Cv not yet up \\
\hline$E$ & $\underline{\mathbf{g}}$ & $\mathrm{Ca}$ & & We & Bh & \\
\hline$E$ & $\mathbf{g}$ & Lc & & We & Mh & perhaps ORR's largest Lc \\
\hline$E$ & $\stackrel{\circ}{E}$ & $\mathrm{Pq}, \mathrm{Dl}$ & DI, & $\mathrm{Cl}, \mathrm{Mf}$ & $\mathrm{Mh}$ & \\
\hline $\mathbf{E}$ & $g$ & & & $W_{r}$ & Mh, Xh & \\
\hline$E$ & $\mathrm{~g}$ & Pf. Lc & & We & $\mathrm{Mh}, \mathrm{Cn}$ & \\
\hline$E$ & $\mathbf{g}$ & & & & $\mathrm{Xh}, \mathrm{Mh}$ & \\
\hline$E$ & g.h $h$ & & & $\mathrm{Cl}$,We & $\mathrm{La} \mathrm{Mh}$ & \\
\hline E & $g$ & $\mathrm{Pq}$ & Lc & Or, We, Mf & $\mathrm{Xh}, \mathrm{Mh}$ & \\
\hline$E$ & $\underline{g}$ & Cv. $\mathrm{Hc}, \mathrm{Pq}$ & & We, Wr & Mh, Mo & \\
\hline$E$ & $\mathbf{g}$ & & & We & Th, Mh & search for Carex muricata \\
\hline$E$ & $g$ & & & We & Mh & possible rare sedge found \\
\hline$E$ & $g$ & Lc. $\mathrm{Pq}$ & & We, Mf & Mh & \\
\hline$E$ & $\mathrm{~g}$ & Sc & Sc & We, Wr & $\mathrm{Bh}, \mathrm{Th}, \mathrm{Pp}, \mathrm{Ma}$ & \\
\hline$E$ & $\underline{\underline{g}}$ & $\mathbf{R p}$ & & Or, Op, Wr & Xh & \\
\hline $\mathbf{E}$ & $g$ & $\mathrm{Rp}$ & $\mathrm{Cg}$ & Or. Wr. Cl & $\mathbf{X h}$ & \\
\hline
\end{tabular}

$\mathrm{Rp}=$ Ruellia purshiana

$\mathrm{Sc}=$ Saxifraga careyana

$\mathrm{Sf}=$ Scirpus fluviatilis

SI = Spiranthes lucida

So $=$ Spiranthes ovalis

$\mathrm{Vt}=$ Viola tripartita var tripartita

\section{LANDSCAPE ELEMENTS}

$\mathrm{Cl}=$ Cliff

$W_{r}=$ Wooded rock outcrop

Or $=$ Open rock outcrop

Rs $=$ Rocky sink

$\mathrm{Mf}=$ Mature forest

We $=$ Wetlands. ponds, springs, seeps

$O p=$ Open areas (natural or maintained)
COMMUNITIES

$\mathrm{Ba}=$ Limestone barren

$\mathrm{Np}=$ Natural Pine

$\mathrm{Pp}=$ Pine Plantation

$\mathrm{Wp}=$ Walnut Plantation

Mh $=$ Mesic Hardwoods

$\mathrm{Xh}=$ Xeric Hardwoods

$\mathrm{Ha}=$ Hay field

$\mathrm{Bu}=$ Bush-hogged

Mo $=$ Mown

$\mathrm{Bh}=$ Bottomland Hardwoods

Th $=$ Thicket

$\mathrm{He}=$ Hemlock

Mx = Mixed pine and hardwood

$\mathrm{La}=\mathrm{Lawn}$

Or = Omamental (landscaping) 
l 


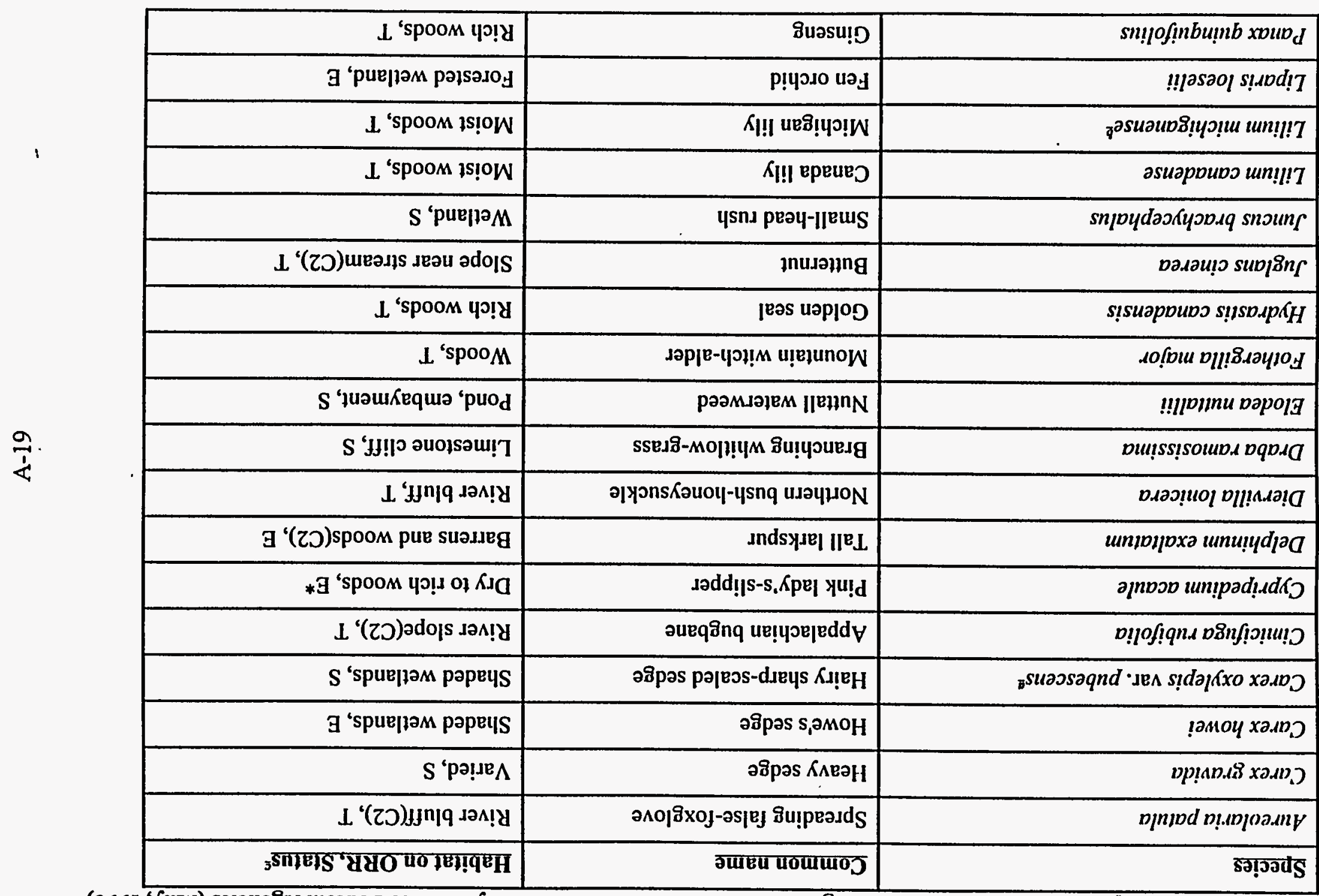

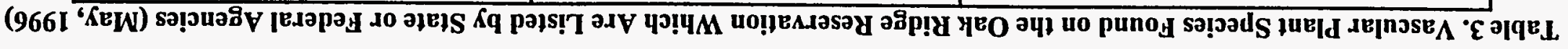


Table 3. (continued)

\begin{tabular}{|l|l|l|}
\hline Species & Common name & Habitat on ORR, Status $^{\varepsilon}$ \\
\hline Plutanthera flava var. herbiola & Tuberculed rein-orchid & Forested wetland, T \\
\hline Platanthera peramoena & Purple fringeless orchid & Wet meadow, T \\
\hline Pycnanthemum verticillatum & Whorled mountain-mint & Wetlands and barrens, E \\
\hline Rhynchospora colorata & White-topped sedge & Rocky edge of pond, S \\
\hline Ruellia purshiana & Pursh's wild-Petunia & Dry, open woods, S \\
\hline Saxifraga careyana & Carey saxifrage & River bluff, sink hole, S \\
\hline Scirpus fluviatilis & River bulrush & Wetland, S \\
\hline Spiranthes lucida & Shining ladies'-tresses & Wetland, T \\
\hline Spiranthes ovalis & Lesser ladies'-tresses & Moist to dry woods, S \\
\hline Viola tripartita var. tripartita & Three-parted violet & Rocky woods, S \\
\hline
\end{tabular}

${ }^{\circ}$ Carex oxylepis var. pubescens was not re-located during surveys 1991-1996.

${ }^{b}$ Lilium michiganense is believed to have been extirpated from the ORR by the impoundment at Melton Hill.

'Status codes:

(C2) Under review for federal listing; was listed under the formely used C2 candidate designation. More information needed to determine status.

E Endangered in Tennessee.

$\mathrm{E}^{*} \quad$ Endangered in Tennessee due to commercial exploitation.

T Threatened in Tennessee.

S Special Concern in Tennessee.

none* No status currently, but high state rank (Tennessee Natural Heritage Program) and under evaluation for state listing. 
Table 4. Occurrence of Listed Vascular Plant Species in OU's, WAG's, Environmentally Sensitive Areas, and Other Areas on the ORR

\begin{tabular}{|c|c|c|c|c|c|c|c|c|c|c|c|c|c|c|c|c|c|c|c|c|c|c|c|c|c|c|c|c|}
\hline $\begin{array}{l}\text { RARE PI.ANT } \\
\text { TAXA }\end{array}$ & Ap & $\mathrm{Cg}_{\mathrm{g}}$ & Ch & C.o & $\mathrm{Cr}$ & (iv & $C_{2}$ & De & DI & $\mathrm{Dr}$ & En & $\mathrm{Fm}$ & He & Je & .Jb & Lc & 1.1 & $\mathbf{P q}$ & Pf & $\mathbf{P p}$ & $\mathbf{P r}$ & Rc & Rp & Se & Sr & $\mathbf{S I}$ & So & vit \\
\hline \multicolumn{29}{|l|}{ 1.0CATION } \\
\hline BCOU4 & & & & & & $x$ & $x$ & & & & & & & & & $x$ & & $x$ & $x$ & $x$ & & & & & & & & \\
\hline $\begin{array}{l}\text { Bethel Valley } \\
\text { (iWoU) }\end{array}$ & $x$ & & & & & & $x$ & $x$ & & & $x$ & & & & $x$ & $x$ & & $x$ & & & $x$ & & & & & & & \\
\hline \multicolumn{29}{|l|}{ CROU2 } \\
\hline $\begin{array}{l}\text { Mellon Valley } \\
\text { GWOU }\end{array}$ & $x$ & & & $x$ & & $x$ & $x$ & & & & $x$ & & & $x^{*}$ & & $x$ & & $x$ & $x$ & $x$ & & & $x$ & & $x$ & & $x$ & \\
\hline K-25 GWOU & $x$ & & & & & $x$ & & & & $x$ & & & & & & & & & & & & & & & & & & \\
\hline WAGi 2 & & & & $x$ & & & & & & & & & & $x^{*}$ & & & & & & & & & & & $x$ & & $x$ & \\
\hline NA I & $x$ & & & & $x$ & & & & & & & & & & & & & & & & & & & $x$ & & & & \\
\hline \multicolumn{29}{|l|}{ NA 2} \\
\hline NA (TVA) 3 & $x$ & & & & $x$ & & & & & & & & & & & & & & & & & & & $x$ & & & & \\
\hline NA 4 & & & & & & & $x$ & & & & & & & & & & & $x$ & $x$ & & & & & & & & & \\
\hline \multicolumn{29}{|l|}{ NA (TVA) 5} \\
\hline NA 6 & $x$ & & & & & & $x$ & & & & $x$ & & $x$ & & & & & $x$ & & & & & & & & & & \\
\hline \multicolumn{29}{|l|}{ NA 7} \\
\hline \multicolumn{29}{|l|}{ NA 8} \\
\hline \multicolumn{29}{|l|}{ NA 9} \\
\hline NA 10 & & & & & & & & & & & & & $x$ & & & & & & & & & & & & & & $x$ & \\
\hline NA 11 & & & & & $x$ & & & & $x$ & & & & & & & & & $x$ & & & & & & $x$ & & & & \\
\hline NA 12 & & & & & & & & & & & & $x$ & & & & & & $x$ & & & & & & & & & & \\
\hline NA 13 & & & & & & & & & & & & & & & & $x$ & & & $x$ & $x$ & & & & & & & & \\
\hline
\end{tabular}


Table 4. (continued)

\begin{tabular}{|c|c|c|c|c|c|c|c|c|c|c|c|c|c|c|c|c|c|c|c|c|c|c|c|c|c|c|c|c|}
\hline $\begin{array}{l}\text { RARE PI.ANT } \\
\text { TAXA }\end{array}$ & $\Lambda_{p}$ & cg & C:h & Co & $\mathrm{Cr}$ & C:v & $C: a$ & De & DI & $\mathrm{Dr}$ & En & $\mathbf{F m}$ & III & Jc & $\mathbf{J b}$ & Le & $\mathbf{L}$ & $\mathbf{P q}$ & Pf & $\mathbf{P p}$ & $\mathbf{P v}$ & $\mathrm{Re}$ & Rp & Se & $\mathrm{Sr}$ & sı & So & vi \\
\hline \multicolumn{29}{|l|}{ I.OC:ATION } \\
\hline NA 14 & $x$ & & & & & & $x$ & & $x$ & & & & & & & & & & & & & & & & & & & \\
\hline NA 15 & & & & & $x$ & & & & & & & & & & & & & & & & & & & $x$ & & & & \\
\hline NA 16 & $x$ & & & & & & & & & & & & & & & & & & & & & & & $x$ & & & & \\
\hline NA 17 & $x$ & & & & & & & & & & & & & & & & & & & & & & & $x$ & & & & \\
\hline \multicolumn{29}{|l|}{ NA 18} \\
\hline NA 19 & $x$ & & & & $x$ & & & & & & & & & & & & & & & & & & & . & & & & \\
\hline NA 20 & $x$ & & & & & & $x$ & & & & & & & & & & & & & & & & & 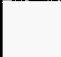 & & & & \\
\hline NA 21 & & & & & & & & & & & & & $x$ & & & & & & & & & & & $x$ & & & & \\
\hline \multicolumn{29}{|l|}{ NA 22} \\
\hline \multicolumn{29}{|l|}{ NA 23} \\
\hline NA 24 & & & & & & & $x$ & & & & & & & & $x$ & & $x$ & & & & & & & & & & & \\
\hline NA 25 & & & & & & & $x$ & & & & & & & & & $x$ & & & & & & & & & & & & \\
\hline \multicolumn{29}{|l|}{ NA 26} \\
\hline \multicolumn{29}{|l|}{ NA 27} \\
\hline \multicolumn{29}{|l|}{ NA 28} \\
\hline \multicolumn{29}{|l|}{ NA 29} \\
\hline NA 30 & $x$ & & & & & & & & & & & & & & & & & & & & & & & & & & & \\
\hline \multicolumn{29}{|l|}{ NA 31} \\
\hline NA 32 & $x$ & $x$ & & & & & & & & & & & & $x^{*}$ & & & & & & & & & & & & & & \\
\hline NA 33 & $x$ & & & & & & & & & & & & & & & & & & & & & & & & & $x$ & & \\
\hline NA 34 & & & & & & & & & & & & & & & & $x$ & & & & & & & & & & & & \\
\hline
\end{tabular}




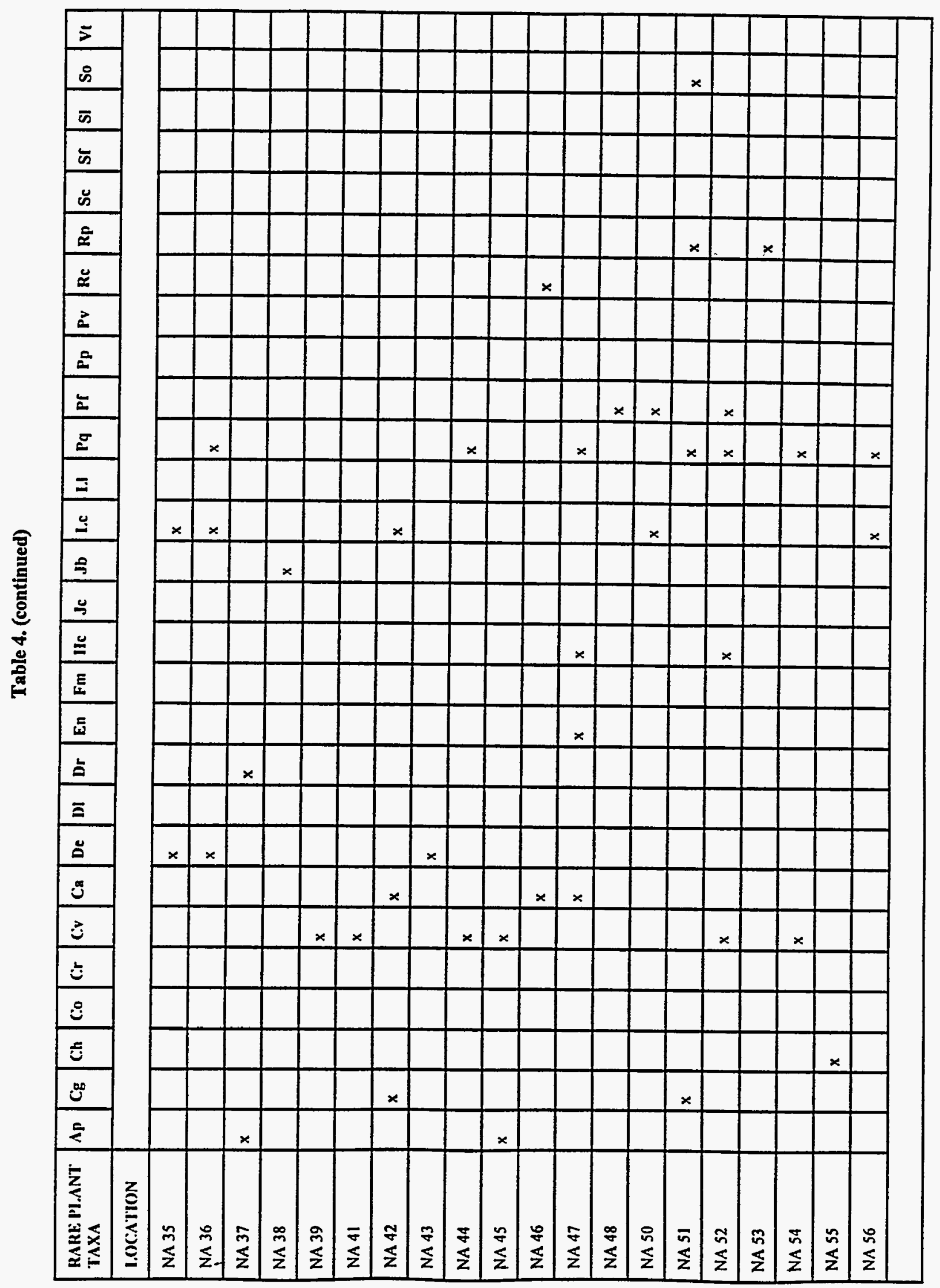


Table 4. (continued)

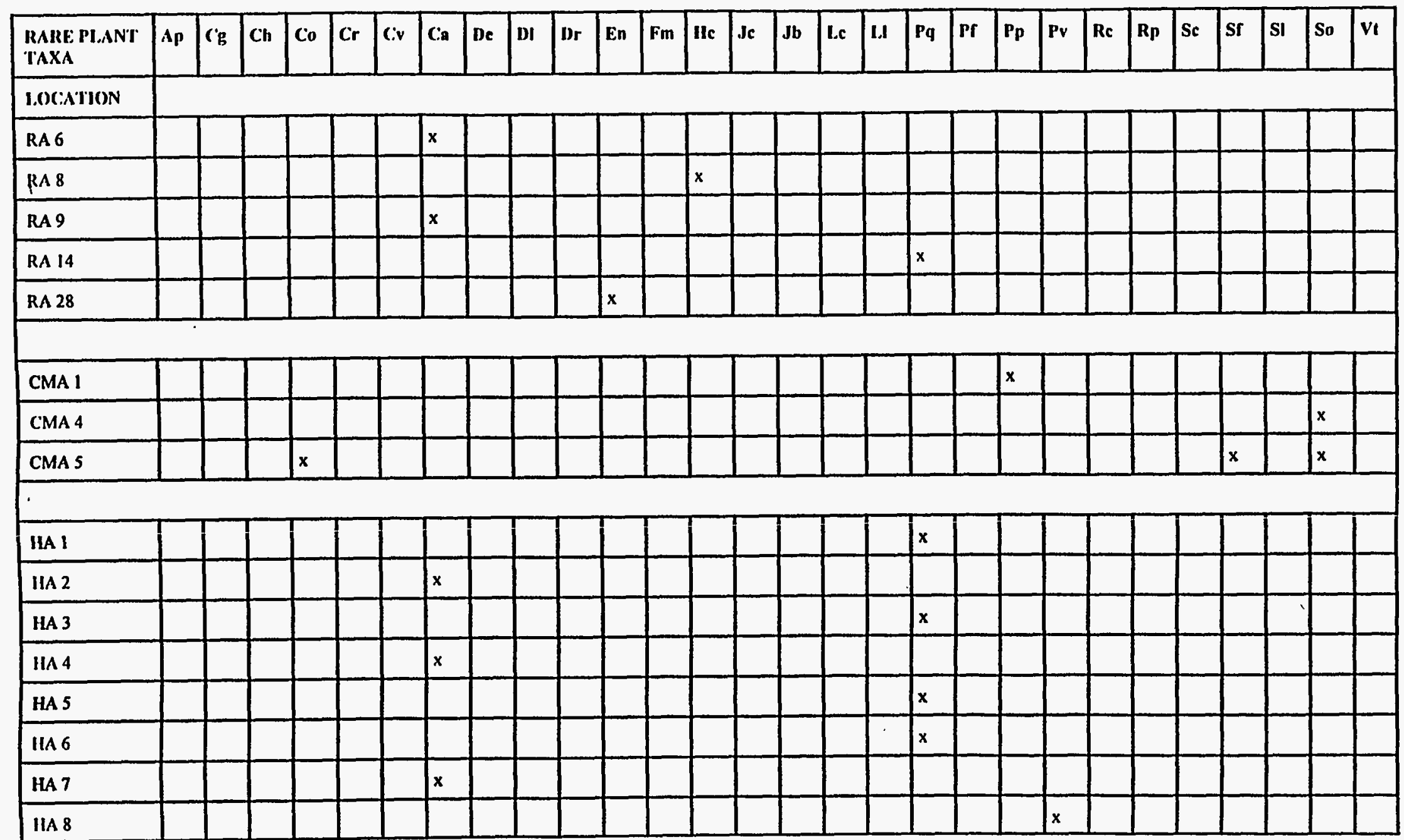

- These areas contain specimens which are most likely Je, but cannot be confirmed due to immaturity of the growth. 
Table 4. (continued)

SIECIES

Aureularia patula

Carex gravida

Carex howei

Carex uxylepis v pubescens

Cîmicifuga rubifolia

Collinsonia verticillata

Cypripedium acaule

Delphinium exaltatum

Diervilla lonicera

Draba ramosissima

Elodea nuttallii

Fothergilla major

Ilydrastis canadensis

Juglans cinerea

Jencus brachycephalus

L.jlium canadense

Liparis loeselii

Panax quinquifolius

Platanthera flava $v$ herbiola

Platanthera peramoena

Pycnanthemum verticillatum

Rhynchospora colorata

Ruellia purshiana

Saxifraga careyana

Scirpus fluviatilis

Spiranthes lucida

Spiranthes ovalis

Viola tripartita var.tripartita

Ap

$\mathrm{Cg}$

$\mathrm{Ch}$

co

Cr

Cv

$\mathrm{Ca}$

De

DI

Dr

En

Fm

Hc

Jc

Jb

Lc

LI

$\mathrm{Pq}$

Pf

Pp

Pv

Rc

Rp

Sc

Sf

SI

So

vi 
Table 5. T\&E Vascular Plant Species Potentially Occurring on the ORR

\begin{tabular}{|c|c|c|c|c|}
\hline TAXON & COMMON NAME & HABITAT & TN STATUS & U.S. STATUS \\
\hline Arabis patens & Spreading rockcress & Limestone slopes & $\mathbf{E}$ & \\
\hline $\begin{array}{l}\text { Asplenium scolopendrium var: } \\
\text { americana }\end{array}$ & American hart's tongue fern & Cave entrance & $\mathrm{E}$ & $\mathrm{T}$ \\
\hline Aster ericoides & White heath aster & Dry, open areas & $\mathrm{T}$ & \\
\hline Aster pratensis & Aster & Dry prairies & $\mathbf{T}$ & \\
\hline Berberis canadensis & American barberry & Rocky bluffs & S & \\
\hline Carex muricata var, angusta & Little prickly sedge & Wetlands & $T$ & \\
\hline Chrysogonum virginianum & Green-and-gold & Rocky woodlands & $T$ & \\
\hline Gnaphalium helleri & Catfoot & Dry forest edge & $\mathrm{s}$ & \\
\hline Heuchera longifolia var. aceriodes & Maple-leaf alumroot & Calcareous woods & $\mathrm{s}$ & \\
\hline Isotria medeoloides & Small whorled pogonia & Under trees & $\mathrm{E}$ & $\mathrm{E}$ \\
\hline Liatris cylindracea & Slender blazing-star & Barren & $\mathrm{E}$ & \\
\hline Lonicera dioica & Mountain honeysuckle & Rocky river banks & $\mathbf{S}$ & \\
\hline Lonicera flava & Yellow honeysuckle & Woodlands & $\mathbf{s}$ & \\
\hline Marshallia grandiflora & $\begin{array}{l}\text { Large-flowered Barbara's- } \\
\text { buttons }\end{array}$ & Gravel bars & $\mathrm{T}$ & (C2) \\
\hline Meehania cordata & Heartleaf meehania & River slopes & $\mathbf{T}$ & \\
\hline Pedicularis lanceolata & Swamp lousewort & $\begin{array}{l}\text { Wet meadow, } \\
\text { seeps }\end{array}$ & $\mathrm{T}$ & \\
\hline Polymnia laevigata & Tennessee leafcup & Woodlands & $\mathrm{s}$ & \\
\hline Rhamnus alnifolia & Alderleaf buckthorn & $\begin{array}{l}\text { Swamps, low } \\
\text { woods }\end{array}$ & $\mathrm{E}$ & \\
\hline
\end{tabular}


Table 5. (continued)

\begin{tabular}{|l|l|l|l|l|}
\hline Rhynchospora capillacea & Capillary beakrush & Limestone seeps & E-P & \\
\hline Silphium laciniatum & Compass plant & Prairies & T & \\
\hline Silphium wasiotense & Kentucky rosinweed & Forest edge & T & \\
\hline Solidago ptarmicoides & Prairie goldenrod & Barren & E & \\
\hline Spiraea virginiana & Virginia spiraea & Gravel bars & E & T \\
\hline Synandra hispidula & Gyandotte beauty & $\begin{array}{l}\text { Rich wooded } \\
\text { slopes }\end{array}$ & T & \\
\hline Tetragonotheca helianthoides & Pineland squarehead & Woods, thickets & E-P & \\
\hline Tomanthera auriculata & Earleaf fox-glove & Barren & E & (C2) \\
\hline Trifolium calcaricum & Running glade glover & Barrens & E & (C2) \\
\hline Woodwardia virginica & Virginia chainfern & Wet acid soils & S & \\
\hline
\end{tabular}

Status codes:

(C2) Under review for federal listing; was listed under the formely used C2 candidate designation. More information needed to determine status.

E Endangered in Tennessee.

$\mathrm{E}^{*} \quad$ Endangered in Tennessee due to commercial exploitation.

T Threatened in Tennessee.

S Special Concerm in Tennessee.

none* No status currently, but high state rank (Tennessee Natural Heritage Program) and under evaluation for state listing. 
Table 6. Additions (144) to the ORR Vascular Flora, 1994 through May, 1996

\begin{tabular}{|l|l|l|l|l|}
\hline GENUS & SPECIES & VARIETY & SYNONYM & ADD YEAR \\
\hline Ageratina & aromatica & - & Eupatorium aromaticum & 1994 \\
\hline Allium & ampeloprasum & - & - & 1994 \\
\hline Ambrosia & bidentata & - & - & 1994 \\
\hline Anthoxanthum & odoratum & - & - & 1994 \\
\hline Arabis & canadensis & - & - & 1994 \\
\hline Aristida & dichotoma & - & - & 1994 \\
\hline Asclepias & viridiflora & - & - & 1994 \\
\hline Aster & divaricatus & - & - & 1994 \\
\hline Aster & laevis & - & - & 1994 \\
\hline Bidens & bipinnata & - & - & 1994 \\
\hline Bromus & altissimus & - & B. latiglumis & 1994 \\
\hline Bromus & tectorum & - & - & 1994 \\
\hline Carex & eburnea & - & - & 1994 \\
\hline Carex & gracillima & - & - & 1994 \\
\hline Carex & stipata & - & - & 1994 \\
\hline Cirsium & arvense & - & - & 1994 \\
\hline Commandra & umbellata & - & - & 1994 \\
\hline Cornus & drummondii & - & - & 1994 \\
\hline Crataegus & calpodenron & - & - & - \\
\hline
\end{tabular}


Table 6. (continued)

\begin{tabular}{|c|c|c|c|c|}
\hline GENUS & SPECIES & VARIETY & SYNONYM & ADD YEAR \\
\hline Cyperus & pseudovegetus & - & - & 1994 \\
\hline Desmanthus & illinoesis & - & - & 1994 \\
\hline Desmodium & glutinosum & - & - & 1994 \\
\hline Draba & ramosissima & - & - & 1994 \\
\hline Eleocharis & parvula & - & - & 1994 \\
\hline Elodea & canadensis & - & - & 1994 \\
\hline Eragrostis & curvula & - & - & 1994 \\
\hline Euphorbia & humistrata & - & Chamaesyce & 1994 \\
\hline Festuca & subverticillata & - & F. obtusa & 1994 \\
\hline Galax & urceolata & - & G. aphylla & 1994 \\
\hline Gaultheria & procumbens & - & - & 1994 \\
\hline Gnaphalium & purpureum & - & - & 1994 \\
\hline Helianthus & decapetalus & - & - & 1994 \\
\hline Hordeum & pusillum & - & - & 1994 \\
\hline Hypericum & prolificum & - & - & 1994 \\
\hline Iris & virginica & - & - & 1994 \\
\hline Iva & annua & - & - & 1994 \\
\hline Juncus & brachycephalus & - & - & 1994 \\
\hline Lechea & racemulosa & - & - & 1994 \\
\hline Linaria & canadensis & & & 1994 \\
\hline
\end{tabular}


Table 6. (continued)

\begin{tabular}{|l|l|l|l|l|}
\hline GENUS & SPECIES & VARIETY & SYNONYM & ADD YEAR \\
\hline Linum & sulcatum & - & - & 1994 \\
\hline Muhlenbergia & tenuiflora & - & - & 1994 \\
\hline Panicum & virgatum & - & - & 1994 \\
\hline Phaseolus & polystachyus & - & - & 1994 \\
\hline Phlox & stolonifera & - & - & 1994 \\
\hline Poa & sylvestris & - & - & 1994 \\
\hline Polygonum & cuspidatum & - & - & 1994 \\
\hline Quercus & michauxii & - & - & 1994 \\
\hline Rhexia & mariana & var.mariana & - & 1994 \\
\hline Rhus & aromatica & - & - & 1994 \\
\hline Rubus & phoenicolasius & - & - & 1994 \\
\hline Salix & alba & - & - & 1994 \\
\hline Scirpus & fluviatilis & - & - & 1994 \\
\hline Sparganium & americanum & - & - & 1994 \\
\hline Spiranthes & tuberosa & - & - & 1994 \\
\hline Sporobolus & clandestinus & - & - & 1994 \\
\hline Sporobolus & indicus & - & - & 1994 \\
\hline Stipa & avenacea & - & - & 1994 \\
\hline Strophostyles & umbellata & - & - & 1994 \\
\hline Tussilago & farfara & - & - & - \\
\hline
\end{tabular}


Table 6. (continued)

\begin{tabular}{|c|c|c|c|c|}
\hline GENUS & SPECIES & VARIETY & SYNONYM & ADD YEAR \\
\hline l'eronica & arvensis & - & - & 1994 \\
\hline Viburmum & prunifolium & - & - & 1994 \\
\hline Vincea & $\min (r$ & - & - & 1994 \\
\hline Alopecurus & carolinianus & - & - & 1995 \\
\hline Amelanchier & laevis & - & - & 1995 \\
\hline Aralia & racemosa & - & - & 1995 \\
\hline Arctinium & minus & - & - & 1995 \\
\hline Arenaria & serpy'llifolia & - & - & 1995 \\
\hline Asclepias & quadrifolia & - & - & 1995 \\
\hline Betula & nigra & - & - & 1995 \\
\hline Buglossoides & arvense & - & Lithospernum & 1995 \\
\hline Calystegia & spithamaea & - & - & 1995 \\
\hline Cardamine & parviflora & - & - & 1995 \\
\hline Carex & atlantica & spp. atlantica & - & 1995 \\
\hline Carex & bromoides & - & - & 1995 \\
\hline Carex & jamesii & - & - & 1995 \\
\hline Carex & muhlenbergii & var. muhlenbergii & - & 1095 \\
\hline Carex & platyphylla & - & - & 1995 \\
\hline Carex & purpurifera & - & - & 1905 \\
\hline Carex & styloflexa & - & - & 190.5 \\
\hline
\end{tabular}


Table 6. (continued)

\begin{tabular}{|l|l|l|l|l|}
\hline GENUS & SPECIES & VARIETY & SYNONYM & ADD YEAR \\
\hline Carex & virescens & - & - & 1995 \\
\hline Celastrus & orbiculatus & - & - & 1995 \\
\hline Chaennorrhinum & minus & - & - & 1995 \\
\hline Chaerophyllum & procumbens & - & - & 1995 \\
\hline Croton & monanthogynus & - & - & 1995 \\
\hline Cyperus & croceus & - & - & 1995 \\
\hline Cyperus & odoratus & - & - & 1995 \\
\hline Disporum & lanuginosum & - & - & 1995 \\
\hline Elaeagnus & pungens & - & - & 1995 \\
\hline Eragrostis & frankii & - & - & 1995 \\
\hline Erythronium & americanum & - & - & 1995 \\
\hline Festuca & rubra & - & - & 1995 \\
\hline Geranium & columbinum & - & - & 1995 \\
\hline Glechoma & hederacea & - & - & 1995 \\
\hline Hedyotis & crassifolia & - & - & 1995 \\
\hline Hemerocallis & fulva & - & - & 1995 \\
\hline Hibiscus & trionum & - & - & 1995 \\
\hline Hydrophyllum & macrophyllum & - & - & 1995 \\
\hline Ilex & verticillata & - & - & 1995 \\
\hline Iris & pseudacorus & - & - & - \\
\hline
\end{tabular}


Table 7. ORNL Photography Numbers for Photographs of T\&E Vascular Plant Species and Their Habitats

\begin{tabular}{|c|c|c|c|c|}
\hline Species & ORNL Number & Photo View & Date & Witness \\
\hline Aureolaria patula & $4341-83$ & Close-up; flowers & $9 / 19 / 81$ & P. D. Part \\
\hline A. patula & $4342-83$ & Habitat; river bluffs & Sep-81 & P.D. Parr \\
\hline A. patula & $7586-87$ & Entire specimen & $9 / 30 / 87$ & P. D. Parr \\
\hline A. patula & $7593-87$ & Close-up & $9 / 30 / 87$ & P. D. Parr \\
\hline A. patula & $7590-87$ & Close-up; leaves \& flower & $9 / 30 / 87$ & P. D. Parr \\
\hline A. patula & 7594-87 & Close-up; leaves \& flower & $9 / 30 / 87$ & P.D.Parr \\
\hline A. patula & $7587-87$ & Close-up; leaves \& seedheads & $9 / 30 / 87$ & P.D. Parr \\
\hline A. patula & $7588-87$ & Entire specimen; no flowers & $9 / 30 / 87$ & P.D.Parr \\
\hline A. patula & $7592-87$ & Partial specimen; leaves & $9 / 30 / 87$ & P. D. Parr \\
\hline A. patula & $7591-87$ & Entire specimen & $9 / 30 / 87$ & P.D. Part \\
\hline Blephilia ciliata & $3796-95$ & |Herbarium specimen & 1995 & L. R. Pounds \\
\hline Carex gravida & $3795-95$ & Herbarium specimen & 1995 & L. R. Pounds \\
\hline Cimicifuga rubifolia & $4340-83$ & Close-up; leaves & $9 / 19 / 81$ & T. Patrick \\
\hline C. rubifolia & $4338-83$ & Close-up; flower spike & $9 / 19 / 81$ & T. Patrick \\
\hline C. rubifolia & $4342-83$ & Entire specimen \& habitat & Sep-81 & T. Patrick \\
\hline C. rubifolia & $6825-87$ & Entire specimen with flowers & & R. A. Cook \\
\hline C. rubifolia & $6823-87$ & Sampling sites & & R.A.Cook \\
\hline C. rubifolia & 6824-87 & Entire specimen; R. A. Cook & & R.A.Cook \\
\hline Collinsonia verticillata & 3792-95 & Entire specimen with flowers & 1995 & L. R. Pounds \\
\hline C. verticillata & $3789-95$ & Habitat & 1995 & L. R. Pounds \\
\hline C. verticillata & $3793-95$ & Habitat & 1995 & L. R. Pounds \\
\hline Cypripedium acaule & 3791-95 & Entire specimens & 1995 & L. R. Pounds \\
\hline C. acaule & $3790-95$ & Entire specimens & 1995 & L. R. Pounds \\
\hline Delphinium exaltatum & $5357-85$ & Close-up; flower spike & $8 / 2 / 79$ & P.D. Parr \\
\hline D. exaltatum & $4387-83$ & Habitat patch & $8 / 2 / 79$ & P. D. Parr \\
\hline Diervilla lonicera & $7904-92$ & Partial specimen & & R. A. Cook \\
\hline D. lonicera & $7903-92$ & Close-up; leaves and flowers & & R. A. Cook \\
\hline Draba ramosissima & $2601-94$ & Specimen grouping & 1994 & L. R. Pounds \\
\hline D. ramosissima & $2600-94$ & Specimen grouping & 1994 & L. R. Pounds \\
\hline D. ramosissima & $2599-94$ & Habitat and specimens & 1994 & L. R. Pounds \\
\hline D. ramosissima & 2598-94 & Habitat and specimens & 1994 & L. R. Pounds \\
\hline D. ramosissima & $2597-94$ & Habitat and specimens & 1994 & L. R. Pounds \\
\hline Elodea nuttallii & $7550-90$ & Pond habitat and plants & 1990 & L.R. Pounds \\
\hline E. nuttallii & $7549-90$ & Close-up; flowers & 1990 & L. R. Pounds \\
\hline Fothergilla major & $4379-83$ & Close-up; leaves \& flowers & $4 / 30 / 79$ & F. Taylor \\
\hline F. major & $4384-83$ & Habitat & May-79 & P. D. Parr \\
\hline Hydrastis canadensis & $4386-83$ & Close-up; flower and leaves & $4 / 15 / 79$ & P.D. Parr \\
\hline & & & & \\
\hline
\end{tabular}


Table 7. (continued)

\begin{tabular}{|c|c|c|c|c|}
\hline Juncus brachycephalus & $7055-94$ & Close-up; seedheads & 1994 & L. R. Pounds \\
\hline J.brachycephalus & $7054-94$ & Specimen grouping & 1994 & L. R. Pounds \\
\hline J. brachycephalus & $7053-94$ & Habitat & 1994 & L. R. Pounds \\
\hline Juglans cinerea & $3787-95$ & Herbarium specimen-1974 & & L.R. Pounds \\
\hline Lilium canadense & $4383-83$ & Entire specimen with flowers & $7 / 12 / 78$ & P. D. Parr \\
\hline L. canadense & $4385-83$ & Close-up; flower & $7 / 12 / 78$ & P. D. Parr \\
\hline L. canadense & $5177-94$ & Close-up; flower & 1994 & R. A. Cook \\
\hline L. canadense & $5170-94$ & Habitat and specimens & 1994 & R. A. Cook \\
\hline L. canadense & $5171-94$ & Entire specimens & 1994 & R. A. Cook \\
\hline L. canadense & $5173-94$ & Entire specimens & 1994 & R. A. Cook \\
\hline L. canadense & $5176-94$ & Close-up; flowers & 1994 & R. A. Cook \\
\hline L. canadense & $5174-94$ & Entire specimen & 1994 & R. A. Cook \\
\hline L. canadense & $5178-94$ & Entire specimen & 1994 & R. A. Cook \\
\hline L. canadense & $5172-94$ & Specimen group; R. A. Cook & 1994 & R. A. Cook \\
\hline L. canadense & $5175-94$ & Habitat & 1994 & R.A. Cook \\
\hline Liparis loeselii & $9051-91$ & Entire specimen & 1991 & P.D. Part \\
\hline L. loeselii & $9052-91$ & Entire specimen & 1991 & P.D. Parr \\
\hline L. loeselii & $9049-91$ & Habitat & 1991 & P.D. Parr \\
\hline L. loeselii & $9050-91$ & Habitat & 1991 & P.D.Parr \\
\hline L. loeselii & $9046-91$ & Habitat & 1991 & P.D. Parr \\
\hline Panax quinquefolius & $4377-83$ & Close-up; leaves and fruit & Aug-78 & P. D. Part \\
\hline Platanthera peramoena & $7548-90$ & Habitat & & L. R. Pounds \\
\hline P. peramoena & $7546-90$ & Close-up; flower head & & L. R. Pounds \\
\hline P. peramoena & $7547-90$ & Close-up; flower head & & L. R. Pounds \\
\hline Saxifraga careyana & $4380-83$ & Specimen group & $5 / 2 / 78$ & P.D. Parr \\
\hline S. careyana & $4375-83$ & Habitat & Aug-77 & P.D. Parr \\
\hline Scirpus fluviatilis & $3794-95$ & Herbarium specimen & & L. R. Pounds \\
\hline Solidago ptarmicoides & & Close-up; flowers & $8 / 5 / 81$ & T. Patrick \\
\hline S. ptarmicoides & $4336-83$ & Entire specimen & $8 / 22 / 83$ & P.D. Part \\
\hline S. ptarmicoides & $6248-86$ & Entire specimen & & \\
\hline S. ptarmicoides & 4339-83 & Habitat & & P. D. Parr \\
\hline Spiranthes ovalis & \begin{tabular}{|l}
$5653-83$ \\
\end{tabular} & Entire specimen & 9/7/83 & P.D. Parr \\
\hline S. ovalis & $5654-83$ & Close-up; flower stalk & $9 / 7 / 83$ & P.D. Parr \\
\hline S. ovalis & $4382-83$ & Close-up; flower stalk & 9/9/78 & P.D.Part \\
\hline S. ovalis & $4376-83$ & Entire specimen & 9/9/78 & P. D. Parr \\
\hline Tomanthera auriculata & $4337-83$ & Close-up; flower stalk & $8 / 8 / 81$ & T. Patrick \\
\hline T. auriculata & $6249-86$ & Close-up; flowers & & P. D. Parr \\
\hline T. auriculata & $6245-86$ & Close-up; flower stalk & & P.D. Parr \\
\hline T. auriculata & $6251-86$ & Close-up; flowers & & P. D. Part \\
\hline T. auriculata & $6417-89$ & Partial specimen; leaves \& stalk & & P.D.Parr \\
\hline T. auriculata & $6250-86$ & Habitat; Monitoring plots & 1987 & P. D. Parr \\
\hline T. auriculata & $6252-86$ & Habitat; Monitoring plots & 1987 & P.D. Part \\
\hline
\end{tabular}


A-35

Table 7. (continued)

\begin{tabular}{|l|l|l|l|l|}
\hline T. auriculata & $6247-86$ & Habitat & 1987 & P.D. Parr \\
\hline & & & & \\
\hline Trillium vaseyi & $3788-95$ & Entire specimen & 1995 & L. R. Pounds \\
\hline
\end{tabular}


Table 8. U.S. State Abreviations

USA

\begin{tabular}{ll} 
AK & Alaska \\
AL & Alabama \\
AR & Arkansas \\
AZ & Arizona \\
CA & California \\
CO & Colorado \\
CT & Connecticut \\
DC & District of Columbia \\
DE & Delaware \\
FL & Florida \\
GA & Georgia \\
HI & Hawaii \\
IA & Iowa \\
ID & Idaho \\
IL & Illinois \\
IN & Indiana \\
KS & Kansas \\
KY & Kentucky \\
LA & Louisiana \\
ME & Maine \\
MA & Massachusetts \\
MD & Maryland \\
MI & Michigan \\
MN & Minnesota \\
MO & Missouri \\
MS & Mississippi \\
\hline
\end{tabular}

$\begin{array}{ll}\text { MT } & \text { Montana } \\ \text { NC } & \text { North Carolina } \\ \text { ND } & \text { North Dakota } \\ \text { NE } & \text { Nebraska } \\ \text { NH } & \text { New Hampshire } \\ \text { NJ } & \text { New Jersey } \\ \text { NM } & \text { New Mexico } \\ \text { NV } & \text { Nevada } \\ \text { NY } & \text { New York } \\ \text { OH } & \text { Ohio } \\ \text { OK } & \text { Oklahoma } \\ \text { OR } & \text { Oregon } \\ \text { PA } & \text { Pennsylvania } \\ \text { PR } & \text { Puerto Rico } \\ \text { RI } & \text { Rhode Island } \\ \text { SC } & \text { South Carolina } \\ \text { SD } & \text { South Dakota } \\ \text { TN } & \text { Tennessee } \\ \text { TX } & \text { Texas } \\ \text { UT } & \text { Utah } \\ \text { VA } & \text { Virginia } \\ \text { VT } & \text { Vermont } \\ \text { WA } & \text { Washington } \\ \text { WI } & \text { Wisconsin } \\ \text { WV } & \text { West Virginia } \\ \text { WY } & \text { Wyoming } \\ & \end{array}$

CANADA

$\begin{array}{ll}\text { AB } & \text { Alberta } \\ \text { BC } & \text { British Columbia } \\ \text { LB } & \text { Labrador } \\ \text { MB } & \text { Manitoba } \\ \text { NB } & \text { New Brunswick } \\ \text { NF } & \text { New Foundland } \\ \text { NT } & \text { Northwest Territories }\end{array}$

$\begin{array}{ll}\text { NS } & \text { Nova Scotia } \\ \text { ON } & \text { Ontario } \\ \text { PE } & \text { Prince Edward Island } \\ \text { PQ } & \text { Quebec } \\ \text { SK } & \text { Saskatchewan } \\ \text { YT } & \text { Yukon Territory }\end{array}$


Table 9. Exotic Plant Species Associated with Adverse Impact to T\&E Species or with High Potential to Adversely Impact T\&E Species

\begin{tabular}{|c|c|c|c|}
\hline GENUS & SPECIES & SYNONYM & COMMON NAME \\
\hline Ailanthus & altissima & - & Tree-of-heaven \\
\hline Albizia & julibrissin & - & Mimosa \\
\hline Arthraxon & hispidus & - & (none) \\
\hline Celastrus & orbiculatus & - & Oriental bittersweet \\
\hline Coronilla & varia & - & Crown-vetch \\
\hline Dioscorea & batatas & - & Chinese yam \\
\hline Elaeagnus & pungens & - & Oleaster \\
\hline Elaeagnus & umbellata & - & Oleaster \\
\hline Festuca & arundinacea & $\begin{array}{l}\text { F. elatior var. } \\
\text { arundinacea }\end{array}$ & Meadow fescue \\
\hline Festuca & pratensis & - & Fescue \\
\hline Glechoma & hederacea & - & Ground-ivy \\
\hline Kummerowia & stipulacea & Lespedeza & Korean bush-clover \\
\hline Kummerowia & striata & Lespedeza & Japanese clover \\
\hline Lespedeza & bicolor & - & Shrubby bushclover \\
\hline Lespedeza & cuneata & - & Cuneate bus-clover \\
\hline Ligustrum & sinense & - & Privet \\
\hline Ligustrum & vulgare* & - & Privet \\
\hline Lonicera & japonica & - & Japanese honeysuckle \\
\hline Lythrum & salicaria & - & Purple loosestrife \\
\hline Mahonia & bealei & - & Oregon grape \\
\hline Mentha & spicata & - & Spearmint \\
\hline Mentha & $\mathrm{x}$ piperita & - & Peppermint \\
\hline Microstegium & vimineum & Eulalia viminea & Nepal grass \\
\hline Murdannia & keisak & Aneilema & Alligator-weed \\
\hline Myriophyllum & spicatum & - & European water-milfoil \\
\hline Nasturtium & officinale & - & Watercress \\
\hline Paulownia & tomentosa & - & Princess-tree \\
\hline Plantago & lanceolata & - & Plantain \\
\hline
\end{tabular}


Table 9. (continued)

\begin{tabular}{|l|l|l|l|}
\hline Poa & pratensis & - & Junegrass \\
\hline Polygonum & persicaria & - & Smartweed \\
\hline Poncircus & trifoliata & - & Trifoliate orange \\
\hline Potamogeton & crispus & - & Pondweed \\
\hline Pueraria & lobata & - & Kudzu \\
\hline Rosa & multiflora & - & Multiflora rose \\
\hline Rubus & phoenicolasius & - & Wineberry \\
\hline Rumex & conglomeratus & - & Dock \\
\hline Sorghum & halepense & - & Johnson grass \\
\hline Tussilago & farfara & - & Coltsfoot \\
\hline Urtica & dioica & - & Stinging nettle \\
\hline Vinca & minor & - & Periwinkle \\
\hline
\end{tabular}


Appendix B

FIGURES 



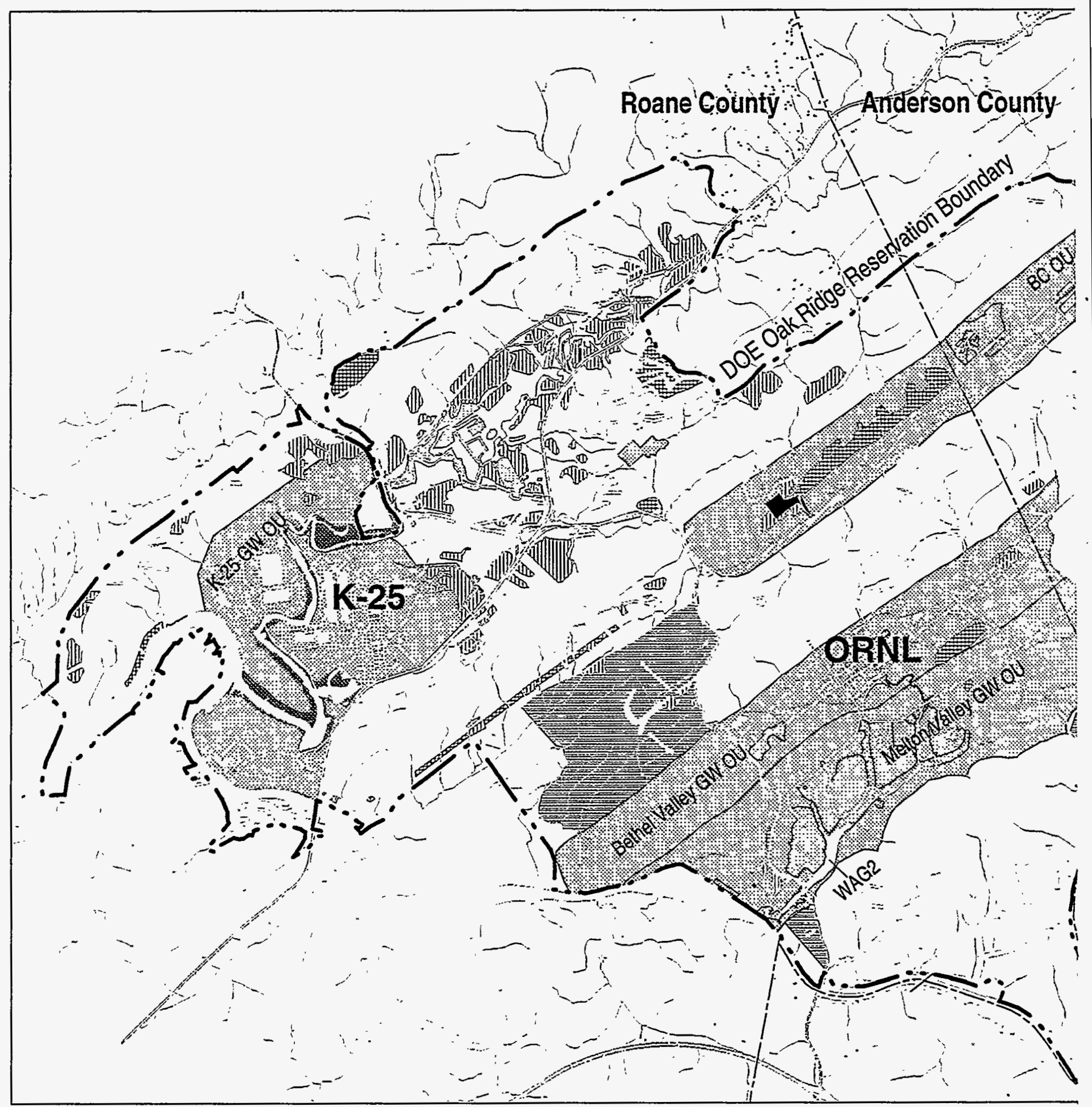

Fig. 1 T\&E Vascular Plant Surveys on the Oak Ridge Reservation (th) 


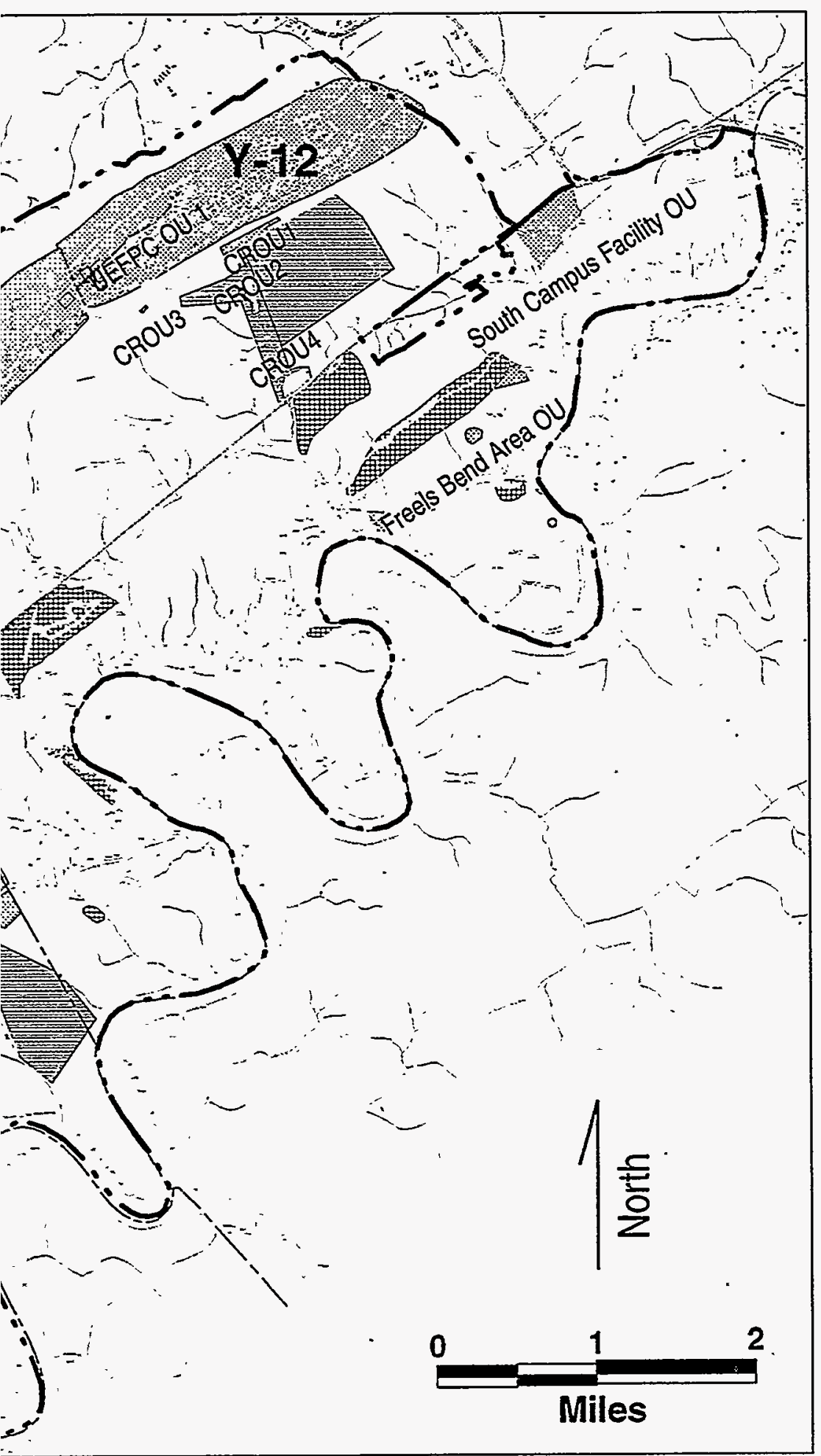

$T \& E$ Vascular Plant Surveys on the Oak Ridge Reservation (through May, 1996)

Special Concern (1995-1996)

Tircel ED-1 (1995)

Low Level Waste Disposal Facility (1995)

Poplar Creek (1994)

1IIII Pine Plantations (timber salvage areas, 1993-1994)

Natural \& Reference Areas surveyed in 1994

Waste Area Groupings (WAG; included in OU)

Operable Units (OU; 1991-1994)

Other Surveys (pre-1992)
COORDINATE SYSTEM:

Tennessee State Plane (NAD 83)

\section{BASE DATA:}

ORNL Shared Data Initiative (SDI)

MAP COMPOSITION

Date: May, 1996

Designer: D. Awl

-JAYCOR Environmental-

Prepared for

the Environmental Restoration Program

by

Environmental Sciences Division Oak Ridge National Laboratory 


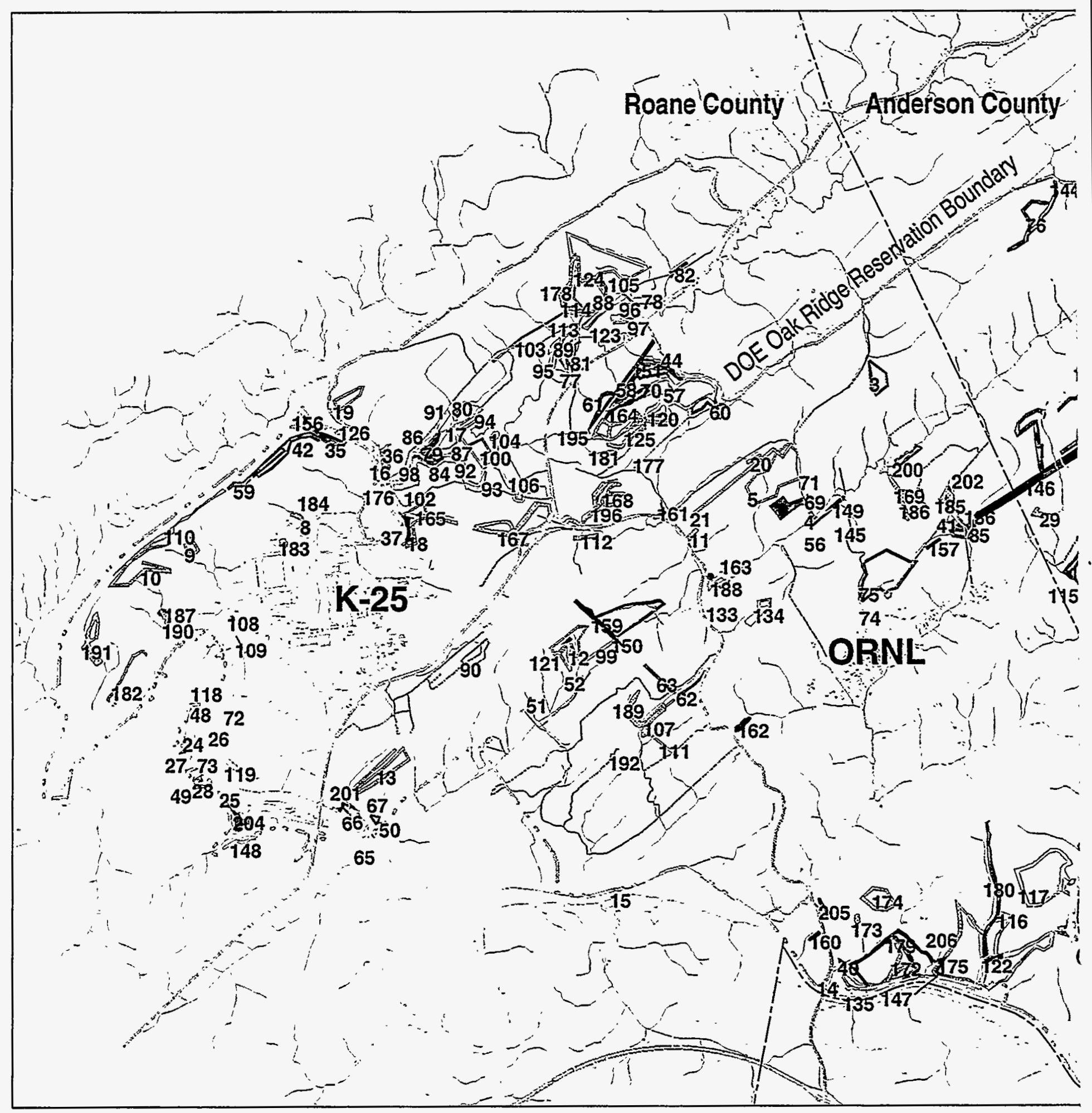

Fig. 2 T\&E Vascular Plant Surveys on the Oak Ridge Reservation (1995- 


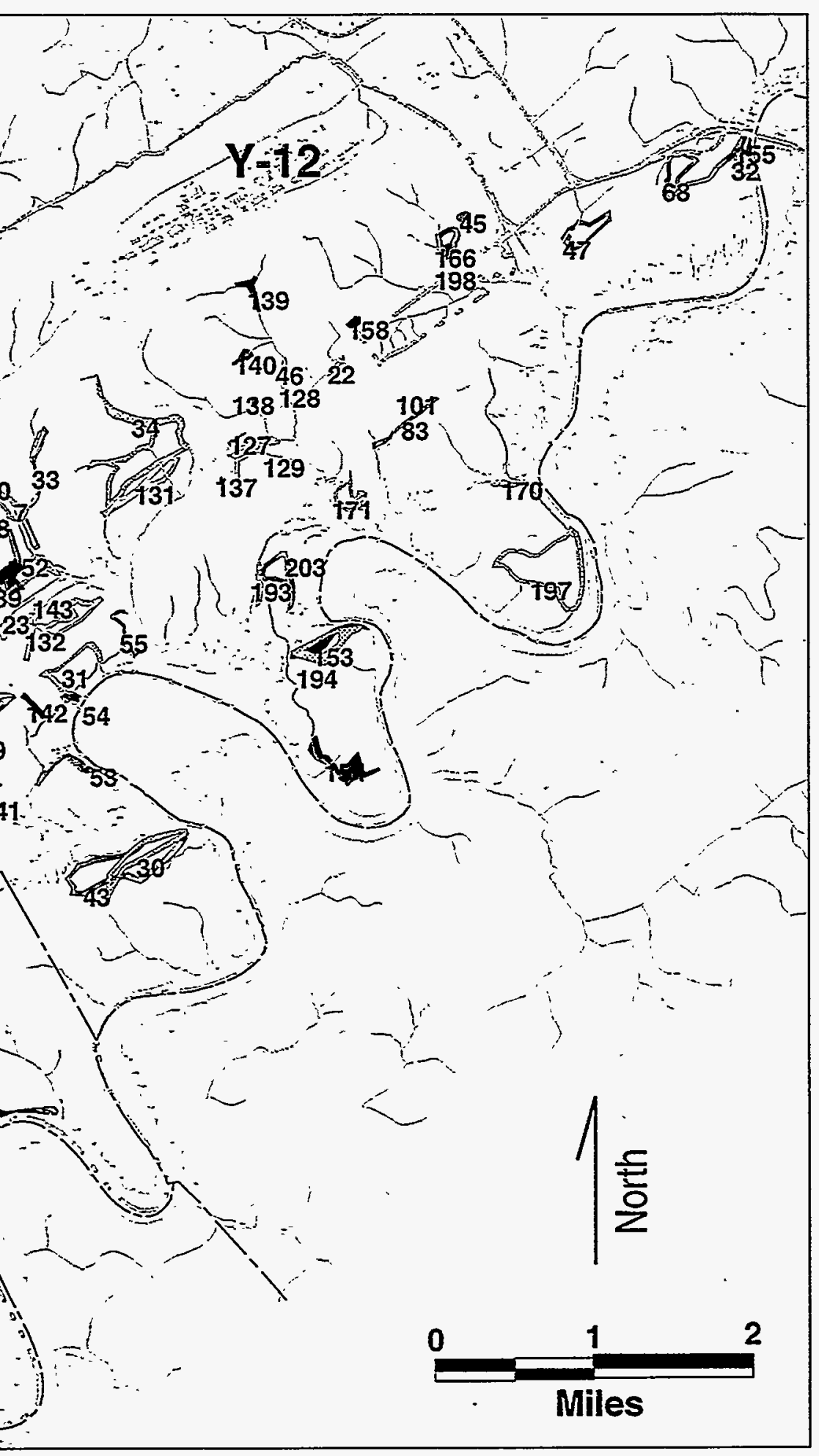

(ay 1990)
T\&E Vascular Plant Surveys on the Oak Ridge Reservation

(1995 through May, 1996) Labeled by Survey Index Number

COORDINATE SYSTEM:

Tennessee State Plane (NAD 83)

\section{BASE DATA:}

ORNL Shared Data Initiative (SDI)

MAP COMPOSITION

Date: May, 1996

Designer: $\mathrm{D}$. Awl

-JAYCOR Environmental-

Prepared for the Environmental Restoration Program by

Environmental Sciences Division Dak Ridge National Laboratory 


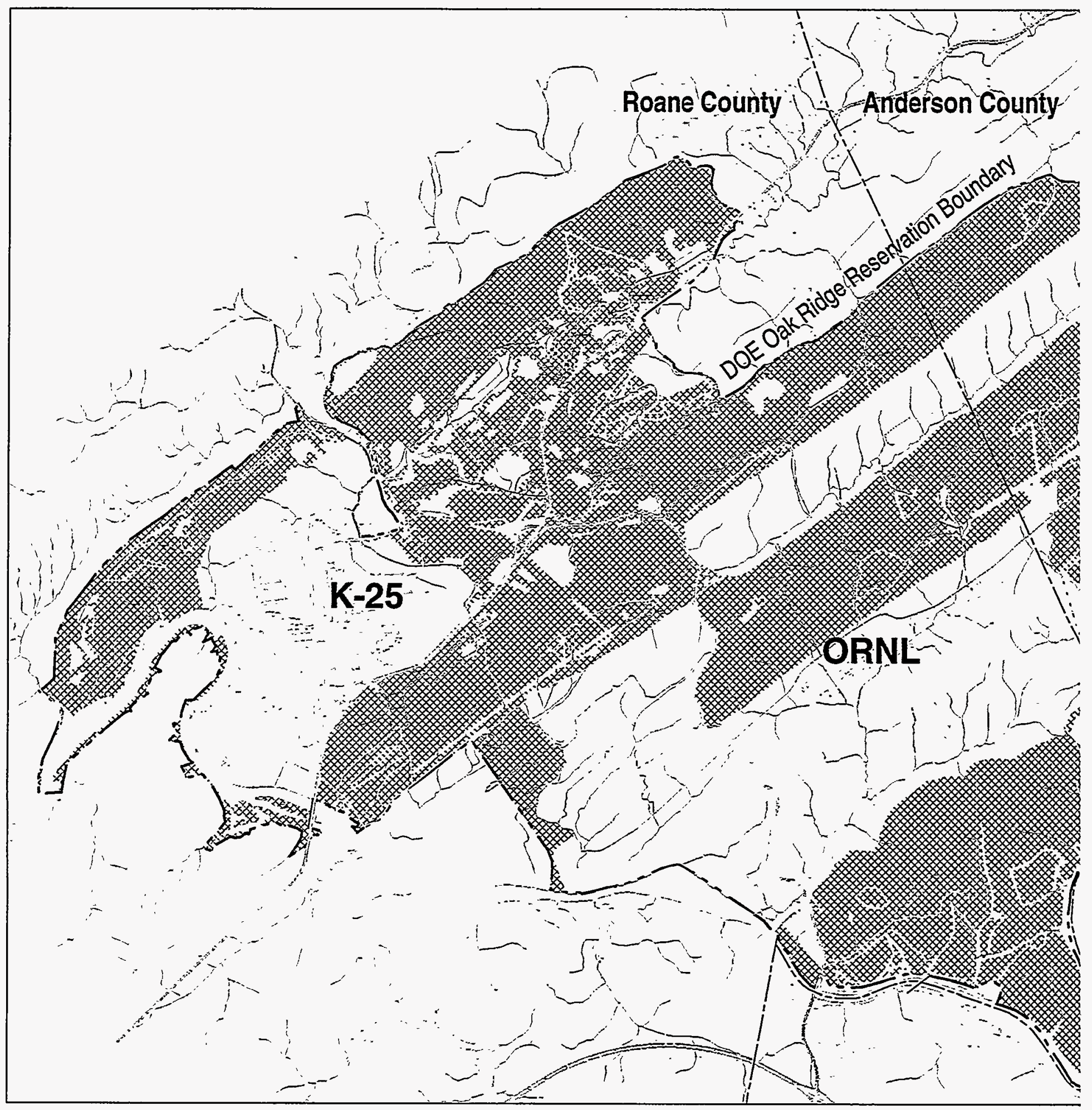

Fig. 3 Gaps in Coverage ofT\&E Vascular Plant Surveys on the Oak Ridge Rese 


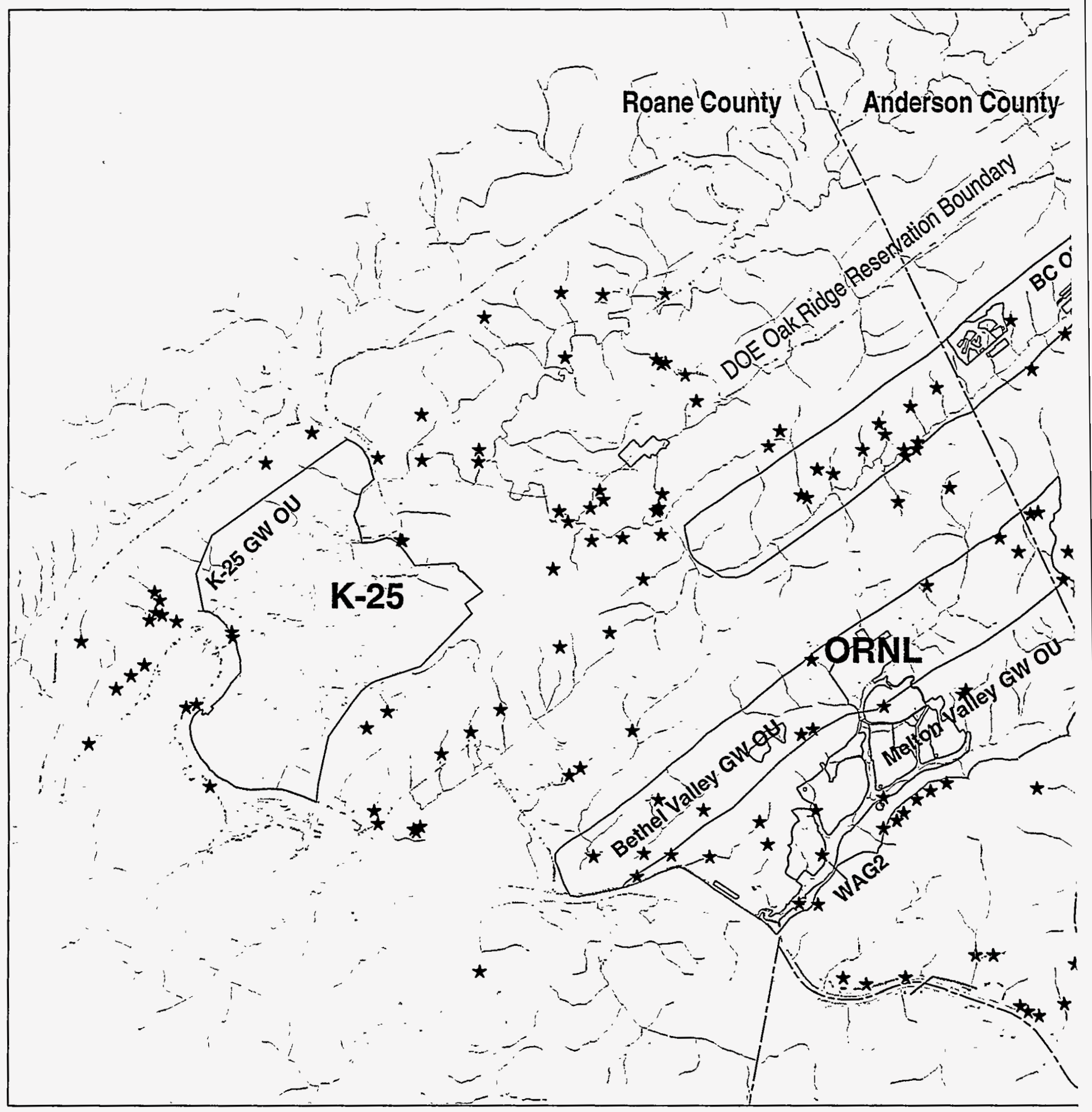

Fig. 4 Point Locations for T\&E Vascular Plant Specieson the Oak Ridge Reservation Base 


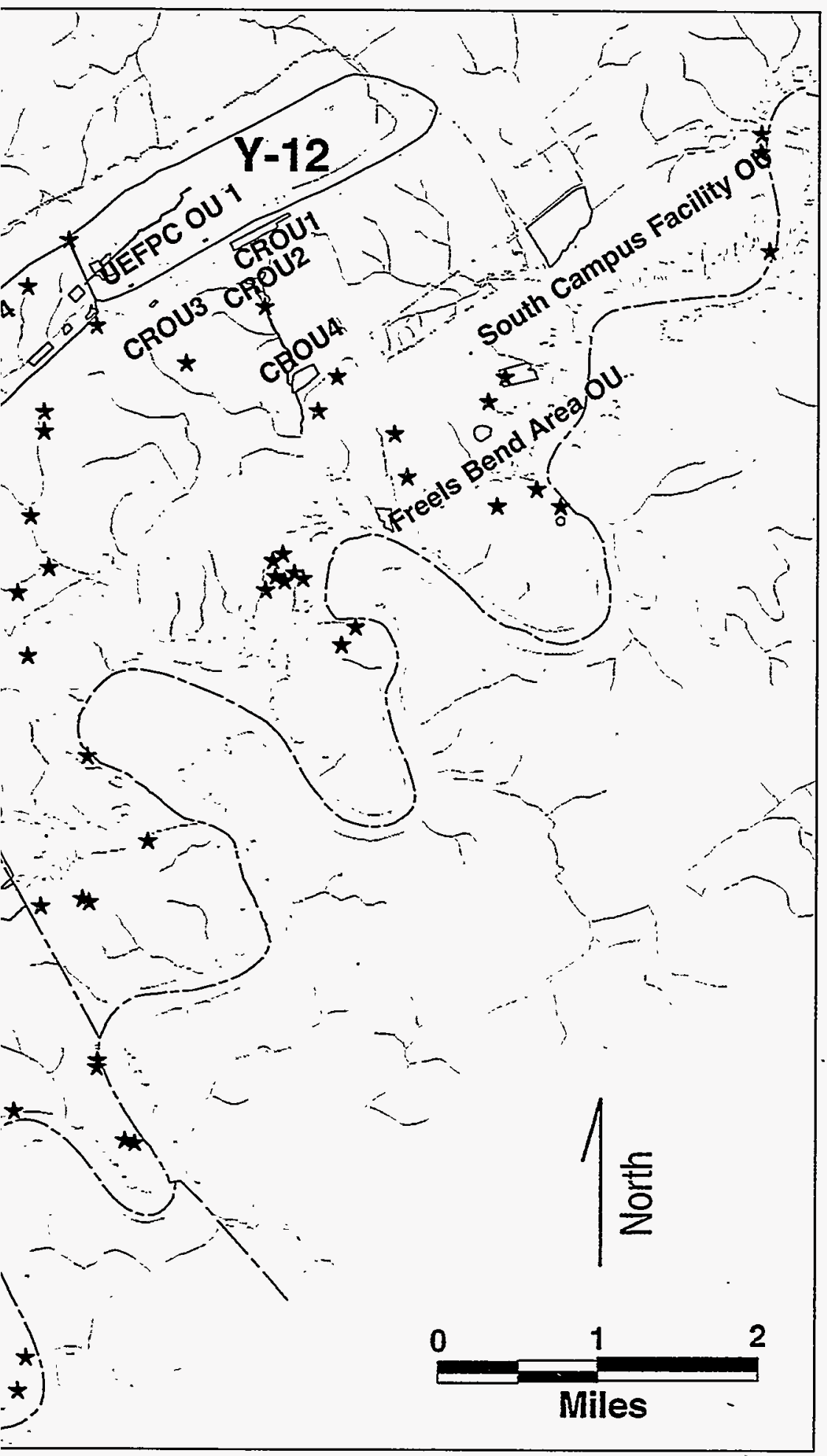

on Field Survey Sample Sites(Through May 1996)
Point Locations for T\&E Vascular Plant Species on the Oak Ridge Reservation Based on Field Survey Sample Sites (Through May, 1996)

Notes: Point locations do not represent the areal extent of these species. Some points appear within the Clinch River; these sites include the now flooded Michigan Lily site, and sites located at the water's edge which may experience temporary flooding.

$\star$ T\&E Vascular Plant Point Locations (267 points)

COORDINATE SYSTEM:

Tennessee State Plane (NAD 83)

BASE DATA:

ORNL Shared Data Initiative (SDI)

MAP COMPOSITION

Date: May, 1996

Designer: D. Awl

-JAYCOR Environmental--

Prepared for

the Environmental Restoration Program

by

Environmental Sciences Division

Oak Ridge National Laboratory 


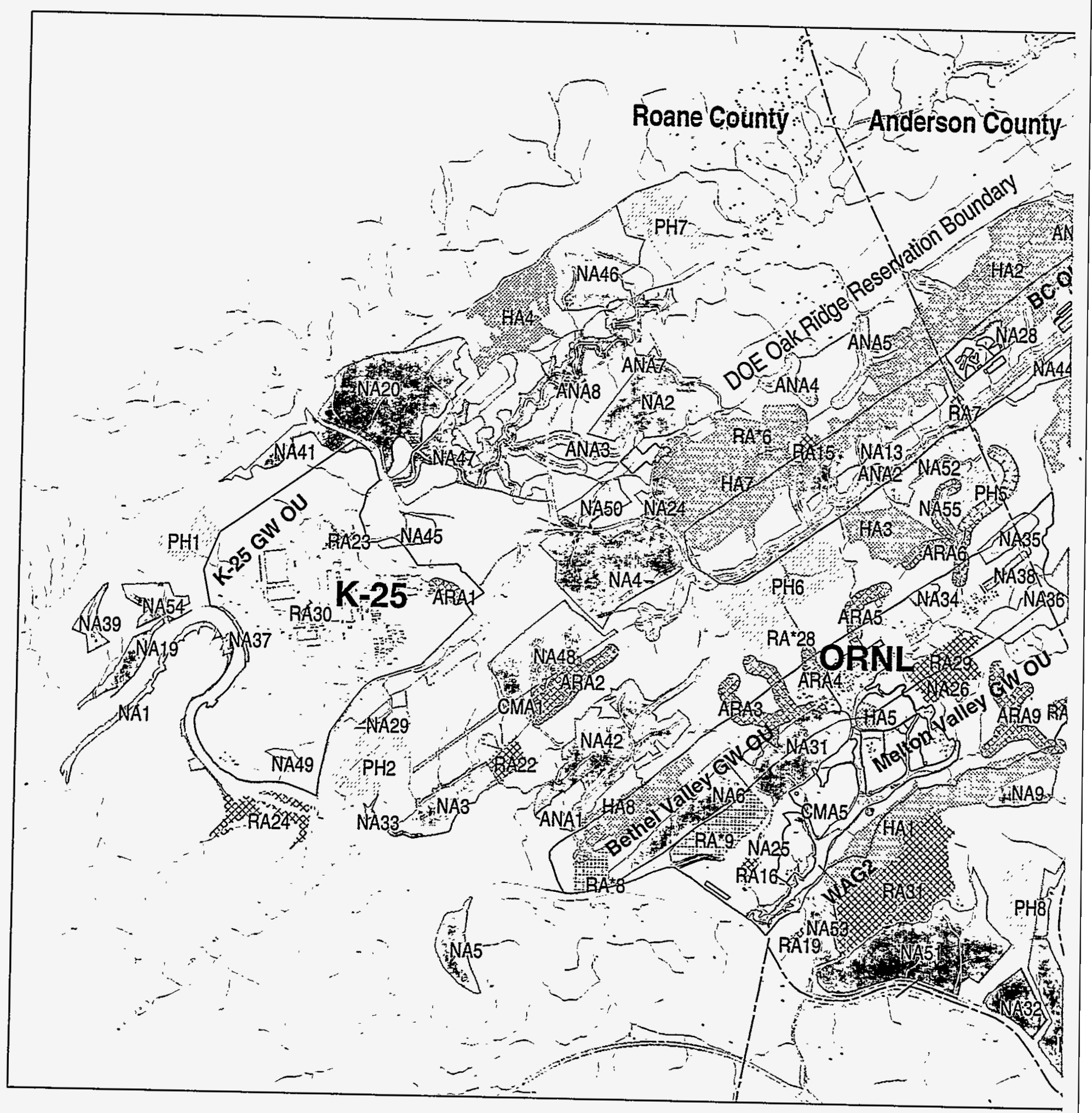

Fig. 5 Environmentally Sensitive Areas on the Oak Ridge Res! 
Appendix C

ORR VASCULAR FLORA DATA BASE 


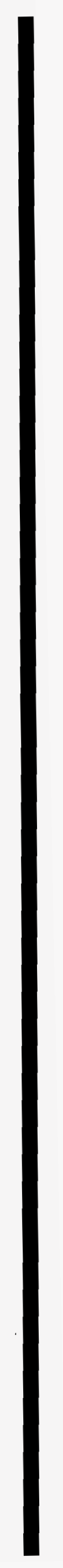




\section{THE ORR VASCULAR FLORA DATA BASE}

This species list is a revision of List 1 in Appendix E of the Resource Management Plan for the Oak Ridge Reservation, Volume 29: Rare Plants on the Oak Ridge Reservation (Cunningham et al 1993). More than 100 additional species have been found on the ORR since 1985. Some species listed in an unpublished report by the Tennessee Valley Authority (TVA) (1950-1953), An Ecological Survey of White Oak Creek on the White Oak Creek, do not appear on the current ORR list because research park staff were unable to locate the corresponding herbarium specimens for verification. These specimens are presumed to have been refiled since they were not found under the species names used in the report. Refiling normally indicates a change in identification. No attempt was made to find the new location of a specimen, i.e., its new identification.

Data base field descriptions:

\section{FAMILY, GENUS, SPECIES, VARIETY}

The scientific names (genus, species, variety and family), are primarily taken from Wofford and Kral (1993). A few taxa are not referenced in this source; other sources were used for these scientific names, and these taxa are indicated in the COMMENTS field. The other sources are Gleason and Cronquist (1991) and Radford, Ahles, and Bell (1986).

Some taxa do not meet criteria for inclusion in the ORR flora but have been included in the data base to clarify their status; these ineligible SPECIES are marked with an asterisk (*). The ELIGIBILITY field indicates why these taxa are not included in the ORR flora.

\section{SYNONYM}

In some cases synonyms for scientific names are given which might be more familiar to the user than those chosen by our sources. If the synonyms differ only as to genus, then only genus is given in the synonym column.

\section{COMMON NAME}

The principle sources used for common names were Great Smoky Mountain Natural History Association and Gleason and Cronquist (1991). A standard list of common names is expected to be published soon by John T. Kartesz and Rosemarie Kartesz. This list may be used in future versions of this data base.

\section{ELIGIBILITY (ORR FLORA)}

The data base contains some taxa which are not eligible for inclusion in the ORR vascular flora but have been retained in the data base to clarify their status; these SPECIES are marked with an asterisk $\left.{ }^{*}\right)$. The column headed ELIGIBILITY indicates why these taxa are not included in the ORR flora:

- $\quad$ el = meets criteria for membership in ORR flora (see note below)

- ne (not established) = exotic taxon from horticulture which has not yet shown that it can survive without horticulture 


\section{$\mathrm{C}-4$}

- $\operatorname{qr}$ (questionable report) $=$ questionable report of the taxon

- hy (hybrid) $=$ a hybrid that does not seem to be established independently of parent species

- id (identification) $=$ the identification is questionable

- $\operatorname{tax}$ (taxonomy) $=$ there may be confusion in the taxonomy

- $\quad$ pl (previous list) = on Mann, Patrick, and De Slem. (1985) (A Checklist of the Vascular plants of the Department of Energy Oak Ridge Reservation), but currently we do not have evidence in the form of a specimens or a confident report from a botanist for the occurrence of the taxon on the ORR

- ot (ownership transferred) $=$ the location where the taxon was found is outside the current ORR boundary (the ORR boundary has changed due to the transfer of "surplus" land)

- nt (new taxon) = the taxon has recently been described, and is likely to occur on the ORR, but there has not yet been a search for it

Note: The following criteria must be met for inclusion in the ORR vascular flora:

1. The taxon is a vascular plant.

2. Verification exists (see PROOF) that the taxon occurs within the ORR boundaries as of October. 1995. Verification includes herbarium specimens, photographs, and confident reports of botanists. We are in the process of obtaining specimens in cases where the only verification is a confident report.

3. The taxon appears capable of maintaining itself indefinitely without horticultural support (a natural occurrence). The list does not include many of the taxa currently used for plantings around buildings, or taxa which were planted originally at homesteads but are gradually dying out as the homestead sites return to natural vegetation.

4. The taxonomic identification of the specimen is accepted. The identification of a specimen may be tentative in several ways: (1) the quality of the available specimen is inadequate, (2) a botanist with expertise in the taxa and able to confirm the identification has not yet been located; (3) the material cannot be clearly identified because it may represent plants unidentifiable by available taxonomic literature, e.g., the material is from a hybrid, diseased, or undescribed plant.

5. The taxon is valid; for example, a taxon may be invalid if it is distinguished from other taxa based on environmentally determined (rather than genetically) determined characters. We try to follow expert opinion as to validity, but the experts do not always agree.

\section{PROOF}

This column lists the verification for the occurrence of each taxon on the ORR:

- $\mathrm{ORRH}=$ specimen in the ORR herbarium

- $O R R H v=$ only specimen stored in the ORR herbarium vault

- $\mathrm{ORRHs}=$ specimen in a special collection at the ORR herbarium (not filed with general specimens)

- $\quad \mathrm{UTK}=$ specimen in the UTK herbarium

- US = specimen in the Smithsonian Institute herbarium 


\section{C-5}

- $\mathrm{DU}=$ specimen in the Duke University herbarium

- $\quad \mathbf{P}=$ photographs in the ORR Environmental Research Park office and in the herbarium

- $\quad r($ report $)=$ reported with confidence by a botanist

\section{CONTAMINATED}

This column indicates taxa that have a specimen sequestered in a vault adjacent to the ORR herbarium at Bldg. 0907. These specimens are contaminated with radioactive material.

$c=$ contaminated

\section{COMMENTS}

This field indicates species which are not included in Wofford and Kral (1993), a source which attempts to list all species naturally occurring in Tennessee. The source used for these species is given in this field. This field also indicates species which are rare in Tennessee and/or East Tennessee (east of the central basin) based on range maps in Chester et al. (1993) and unpublished range maps kept in the University of Tennessee herbarium.

\section{TN NATIVE, VS. EXOTIC}

This column indicates whether the taxon is considered to be native or exotic in Tennessee according to Wofford and Kral (1993). Wofford and Kral do not define native in this 1993 work. Native to Tennessee might be defined as occurring naturally in Tennessee previous to the influence of European culture and not solely in Native American cultivation. Taxa may be native to Tennessee but not to East Tennessee, e.g., bald cypress; such taxa are not differentiated in the data base. In many cases direct evidence of pre-European occurrence is lacking, and the conclusion is a best guess. Exotic is taken to mean not native. Aggressive vs. passive was determined based on the field experience of ORR Research Park botanical staff.

- $\quad$ nat = native to TN (may not be native to the ORR)

- $\quad e a=$ (exotic aggressive), observed to exclude native species on the ORR

- $\quad$ ea? = (exotic aggressive questionable), not yet observed to exclude native species but has characteristics that make it likely to become a problem in the future

- $\quad \mathrm{ep}=$ (exotic passive), not observed to exclude nor expected to exclude native species

- $\quad$ ep? $=$ (exotic passive questionable), not observed to threaten native species, but information is lacking

- $e=$ (exotic), no information on the threat to native species

\section{FREQUENCY (ORR)}

This field indicates the approximate frequency of occurrence of each taxon on the ORR as estimated by research park staff based on field experience. Except for rare species, frequencies for taxa are subjective. Question marks are used with the codes to indicate a higher degree of uncertainty. The frequency codes are a modification of those used by the Great Smoky Mountains Natural History Association (no publication date) in Flowering Plants of the Great Smoky Mountains National Park. 
- $\quad c=$ (common) found regularly in common habitats

- $f=$ (frequent) found somewhat irregularly in common habitats

- $0=$ (occasional) found at 14-20 sites

- $\quad \mathrm{i}=$ (infrequent) found at 9-13 sites

- $s=($ scarce $)$ found at 4-8 sites

- $\quad r=$ (rare) found at 2-3 sites or at one site with more than 20 individuals

- $\quad \mathbf{v r}=$ (very rare) found at 1 site with less than 20 individuals

- $\quad ?=$ (status uncertain) higher than normal level of uncertainty

\section{TN STATUS}

This column lists the status assigned to the taxon by TDEC. Codes and code assignment to species are taken from an unpublished TDEC list (1994).

TN code:

- $\quad \mathbf{S}=$ special concern

- $\mathrm{T}=$ threatened

- $\quad E=$ endangered

- $\mathrm{E}^{*}=$ endangered due to commercial exploitation

- $\quad \mathbf{P}=$ possibly extirpated from Tennessee [records are historical (not current)]

\section{U.S. STATUS}

This column lists the status assigned to these taxa by the FWS (1993).

- $\quad \mathrm{C}_{2}=$ a second priority level candidate for federal listing under the Endangered Species Act (currently called species of concem)

- $\quad 3 \mathrm{C}=$ a species which was a candidate for listing but did not achieve listing and is no longer considered a candidate for listing

\section{R2IND (WETLAND INDICATOR STATUS)}

The FWS (Reed 1988) has developed a classification system that assigns species to wetland indicator classes according to the frequency with which these species occur in a wetland. These indicators are used to establish the hydrophytic vegetation criterion for identification and delineation of jurisdictional wetlands (U.S. Army Corps of Engineers 1987). "R2IND" refers to the indicator (IND) that has been assigned to the species in EPA Region 2 (R2), which includes most of the southeastern U.S. A species which is considered to be an upland species in all regions of the U.S. is not included on this list. This creates a problem in interpreting this list because species found on the ORR and not found in Reed (1988) may be upland or not treated by Reed and thus may have a status other than upland. In these cases, a judgment was made by research park staff. If the species appeared to be an upland species, it was given that code in the column. If not, a question mark (?) was placed in that column, and in some cases a wetland indicator code was given by the staff for the species as seen on the ORR in another 
column (ORRIND). In a few cases observations on the ORR did not agree with the indicator code assigned by Reed. These disagreements are indicated by an alternative indicator codes in the ORRIND column.

ORRIND (ORR alternative wetland indicator)

If a species is not listed in Reed (1988), it is generally assumed to be an upland species. If the species appears to exist in only xeric, upland situations on the ORR, the UPL indicator was placed in the R2IND column. However, some of these species have routinely been found in wetland conditions on the ORR. In this case a question mark has been placed in the R2IND column, and in the ORRIND column has been placed an unoffical indicator status for the species based on the professional judgment of the research park staff. The ORRIND column also includes alternative indicators for some species for which field observations were not in agreement with the indicator listed by Reed. The ORRIND column should be considered preliminary and should not be used in conducting wetland determinations.

These codes and their assignment are taken from Reed (1988) except for ? and in some cases for UPL (see previous paragraph). Percents indicate the probability that the species will occur in a wetland (wetland fidelity or frequency).

- UPL(upland) $=<1 \%$ wetland fidelity.

- FACU (facultative upland) = wetland fidelity in the range $1-33 \%$

- FACU- (facultative upland -) = wetland fidelity in the lower part of the range 1-33\%

- FACU+ (facultative upland + ) = wetland fidelity in the upper part of the range 1-33\%

- FAC (facultative) $=$ wetland fidelity in the range $34-66 \%$

- FAC- (facultative -) = wetland fidelity in the lower part of the range 34-66\%

- $\mathrm{FAC}+($ facultative +$)=$ wetland fidelity in the upper part of the range 34-66\%

- FACW (facultative wetland) = wetland fidelity in the range $67-99 \%$

- FACW- (facultative wetland -) = wetland fidelity in the lower part of the range 67-99\%

- FACW+ (facultative wetland +$)=$ wetland fidelity in the upper part of the range $67-99 \%$

- $\quad$ OBL (obligate) $=>99 \%$ wetland fidelity

- $\quad$ NI (no indicator) $=$ no indicator was assigned because of insufficient information

- $\quad \mathrm{NO}=$ not believed to be found in Region 2 by Reed

- $\quad \mathrm{NA}=$ no indicator status assigned because of lack of agreement among those polled

- ? = the taxon was not found in Reed (1988), but it does not appear to be an upland species (UPL) 


\section{ADDITIONAL DATA FIELDS}

The following data fields are not included in this appendix but are available in the complete data base on OREIS.

\section{TAXONOMIC GROUPING}

Taxa are broken down into the following general groups:

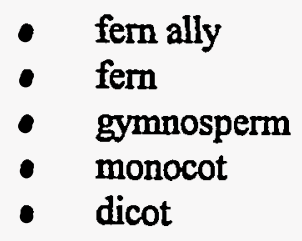

\section{LIFE SPAN}

This field indicates whether a species is an annual, biennial, perennial, or a combination of these. Information was compiled from the Soil Conservation Service, Gleason and Cronquist (1991), and the national PLANTS data base (USDA, NRCS 1995). Where the Soil Conservation Service (1982) and Gleason and Cronquist (1991) disagreed, information from Gleason and Cronquist was used with a question mark In a few cases no information was available from these sources, and only a question mark was used for the code. Reproductive schedule within a species may vary with variety, seasonal weather conditions, and/or geographical region.

- annual = a plant that reproduces and dies after 1 year (one reproductive period)

- biennial = a plant that reproduces and dies after 2 years (one reproductive period)

- perennial $=$ a plant that lives more than 2 years (usually more than one reproductive period)

\section{STRATA}

This column separates herbaceous (coded as grasslike or forb) plants from woody plants and divides the woody plants by growth form. The classification of woody plants used in Trees of the Great Smoky Mountains (Great Smoky Mountains Natural History Association, no publication date) has been followed with an additional code ( $\mathrm{h}$, hemishrub) taken from USDA (1982). The decision as to which code to use for a species was influenced by observations on the ORR.

- $\quad c t=$ canopy tree

- $\mathrm{ut}=$ understory or small tree

- $\mathrm{sh}=\mathrm{shrub}$

- ss (sub-shrub) = very small shrub (normally less than $30 \mathrm{~cm}$ high and often not of typical shrub form)

- $w v=$ woody vine 


\section{C-9}

- hs (hemishrub) = some woodiness at the base of the plant (suffrutescent)

- gr (grasslike) = a grass, sedge, or rush

- $\quad$ fo (forb) $=$ an herbaceous plant that is not grasslike (G) nor a vine (V)

- $\quad v i=$ an herbaceous vine

\section{SYMBIOSIS}

This column indicates plants with special features. Information was compiled from the Soil Conservation Service (1982), Gleason and Cronquist (1991), and the national PLANTS data base (USDA, NRCS 1995). Where the Soil Conservation Service and Gleason and Cronquist disagreed, information from Gleason and Cronquist was used with a question mark.

- epiphyte $=$ a plant growing on a tree which does not have roots in the ground nor in the living part of the tree (e.g. mistletoe is not considered to be an epiphyte but rather a parasite)

- $\quad$ parasite $=$ a plant that gains all or a significant amount of its nutrition from another vascular plant by root penetration

- mycotroph = a plant that gains most of its nutrition from association with a fungus (in certain cases loosely called saprophytic)

\section{AQUATIC HABIT}

This column indicates plants with special features. Information was compiled from the Soil Conservation Service (1982), Gleason and Cronquist (1991), and the national PLANTS data base (USDA, NRCS 1995). Where the Soil Conservation Service and Gleason and Cronquist disagreed, information from Gleason and Cronquist was used with a question mark.

- $\quad$ submersed $=$ a plant that is normally entirely. under water

- emergent = a plant normally growing in water with part of the plant above the water

- $\quad$ floating = a plant normally'growing in water with part or all of the plant floating at the water surface (some are rooted in soil below the water) 


\section{LITERATURE CITED}

Chester, E. W. et al. 1993 Atlas of the Tennessee Vascular Plants, Volume 1, Pteridophytes, Gymnosperms, Angiosperms: Monocots, Center for Field Biology, Austin Peay State University, Clarksville, Tenn.

Cunningham, M. et al. 1993. Resource Management Plan for the Oak Ridge Reservation, Volume 29: Rare Plants on the Oak Ridge Reservation, Oak Ridge National Laboratory . Oak Ridge, Tenn.

Gleason, H. A. and A. Cronquist 1991. Manual of Vascular Plants of Northeastern United States and Adjacent Canada, Second Edition,. Bronx, N.Y.

Great Smoky Mountains Natural History Association (no date). Flowering Plants of the Great Smoky Mountain,. Great Smoky Mountains Natural History Association. Gatlinburg, Tenn.

Great Smoky Mountains Natural History Association (no date). Trees of the Great Smoky Mountains, Great Smoky Mountains Natural History Association, Gatlinberg, Tenn.

Mann, L. K., T. S. Patrick, and H. R. De Selm 1985. "A Checklist of the Vascular plants of the Department of Energy Oak Ridge Reservation, Tenn.," Acad. Sci. 60(11):8-12.

Radford, A. E., H. E. Ahles, and C. R. Bell 1986. Manual of the Vascular Flora of the Carolinas, The University of North Carolina Press. Chapel Hill, N.C.

Reed, P. B., Jr. 1988 National List of Plant Species that Occur in Wetlands: National Summary, U.S. Fish and Wildlife Service.

Tennessee Department of Environment and Conservation 1994. Rare Plants of the State of Tennessee, unpublished.

U. S. Army Corps of Engineers 1987. Wetlands Delineation Manual. Technical Report Y-87-1, Waterways Experiment Station, Vicksburg, Miss.

U. S. Department of Agriculture 1982. National List of Scientific Plant Names, U. S. Department of Agriculture (Soil Conservation Service). SCS-TP-159.

U. S. Department of Agriculture, NRCS 1995. The Plants Data Base, National Plant Data Center, Baton Rouge, La.

U. S. Fish and Wildlife Service 1993. "Plant Notice of Review," Federal Register (Sept. 30, 1993, 50 CFR 17).

Wofford, B. E., and R. Kral 1993. Checklist of the Vascular Plants of Tennessee, Botanical Research Institute of Texas, Inc., Fort Worth, TX. 
C-11

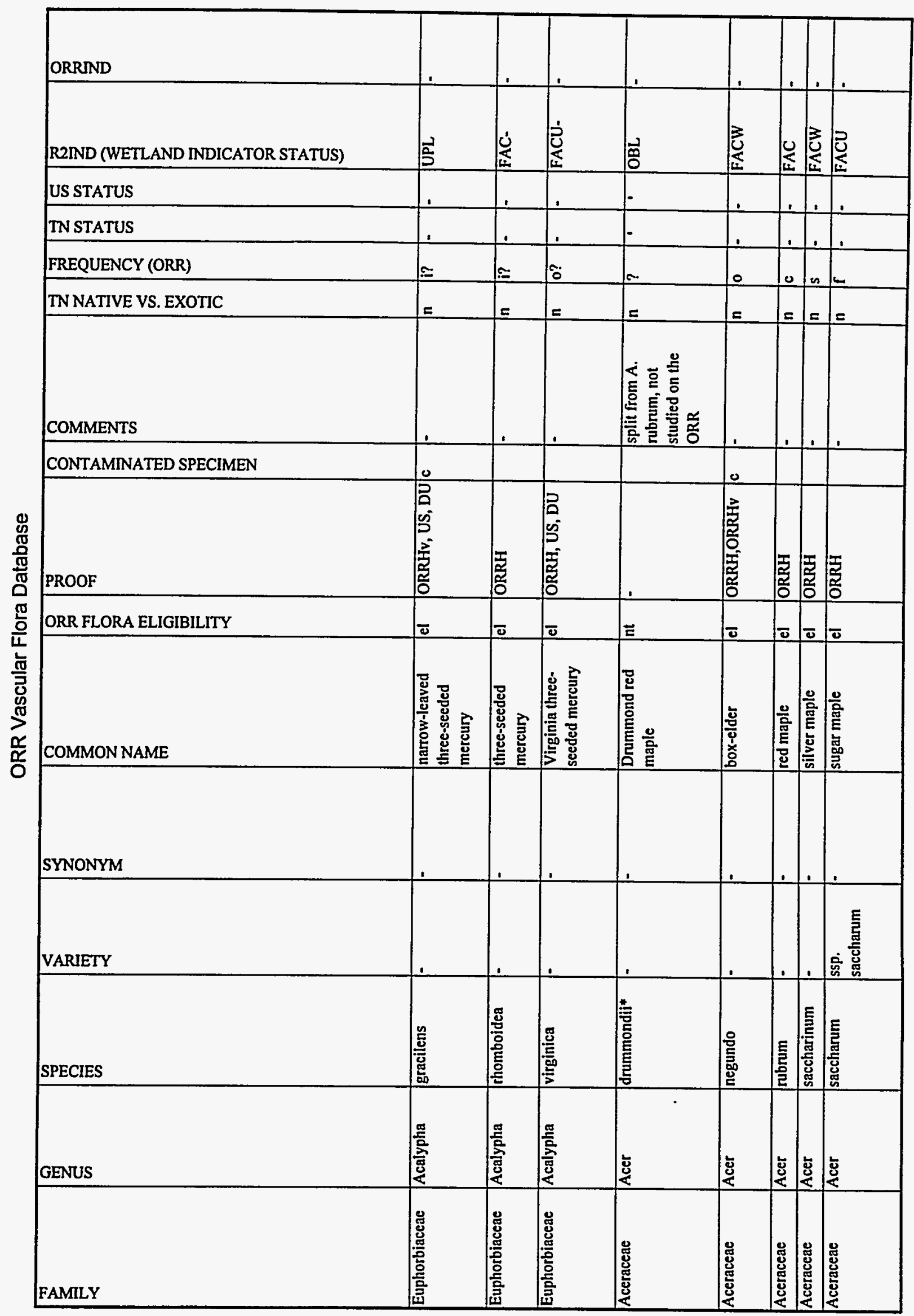




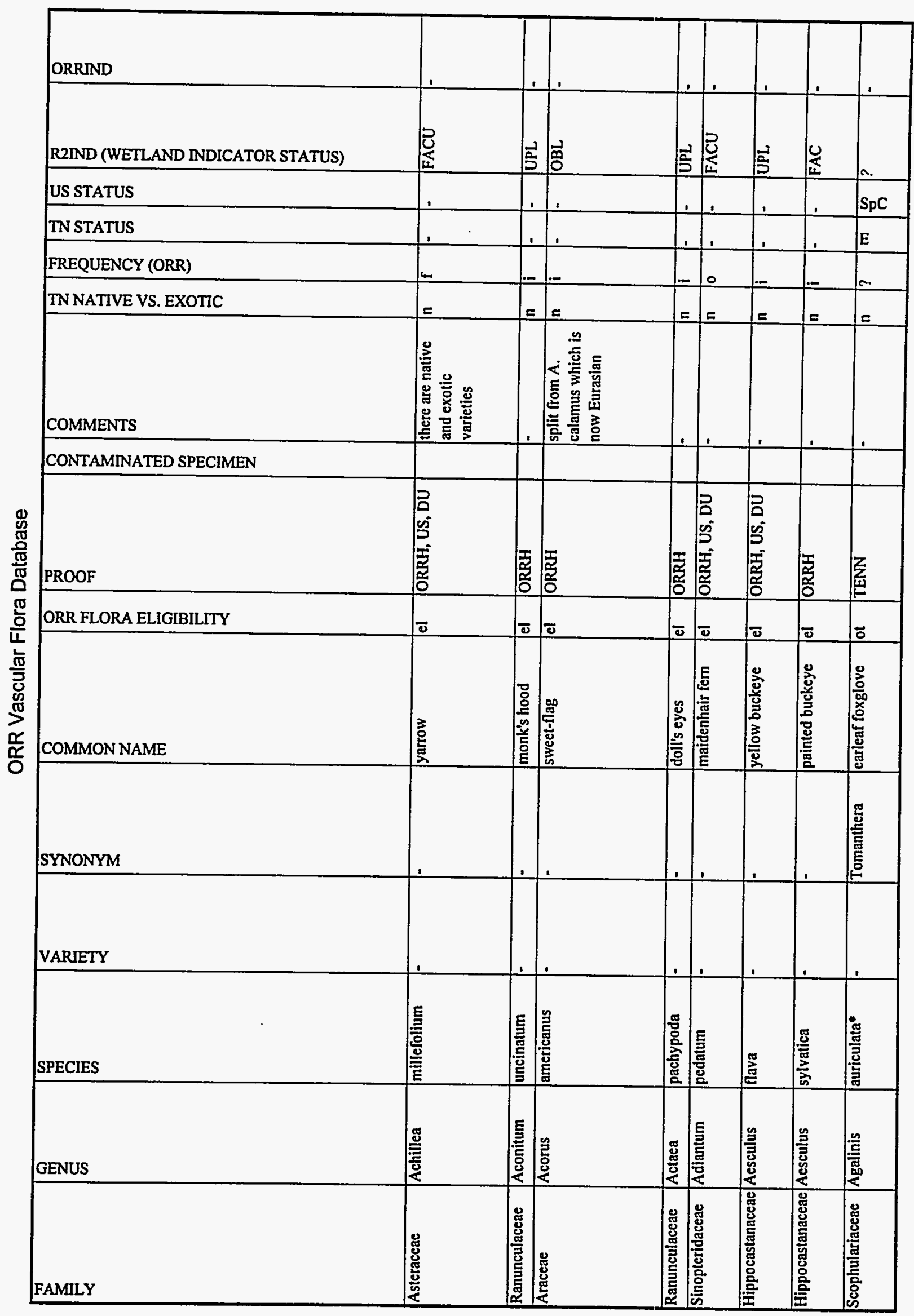




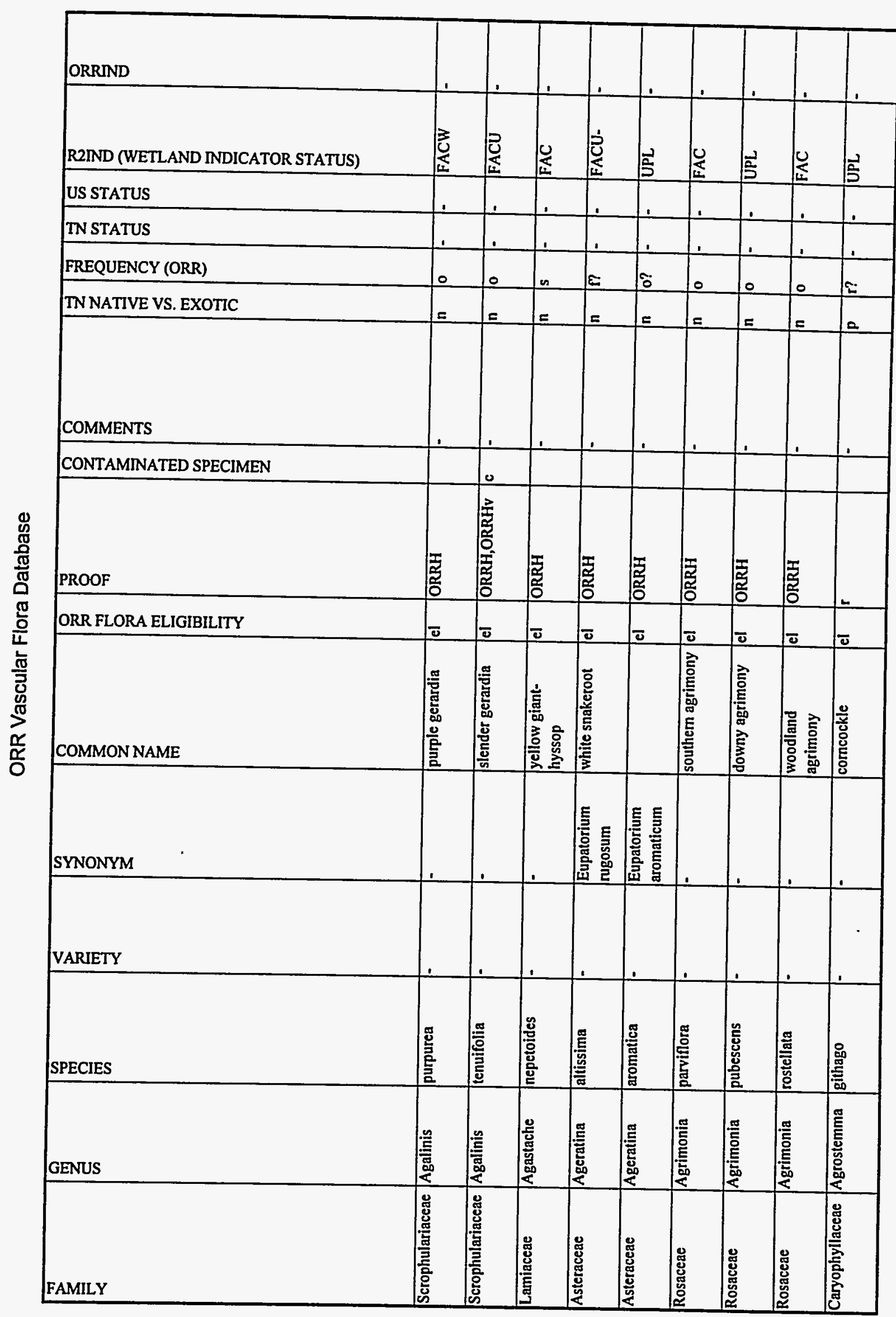




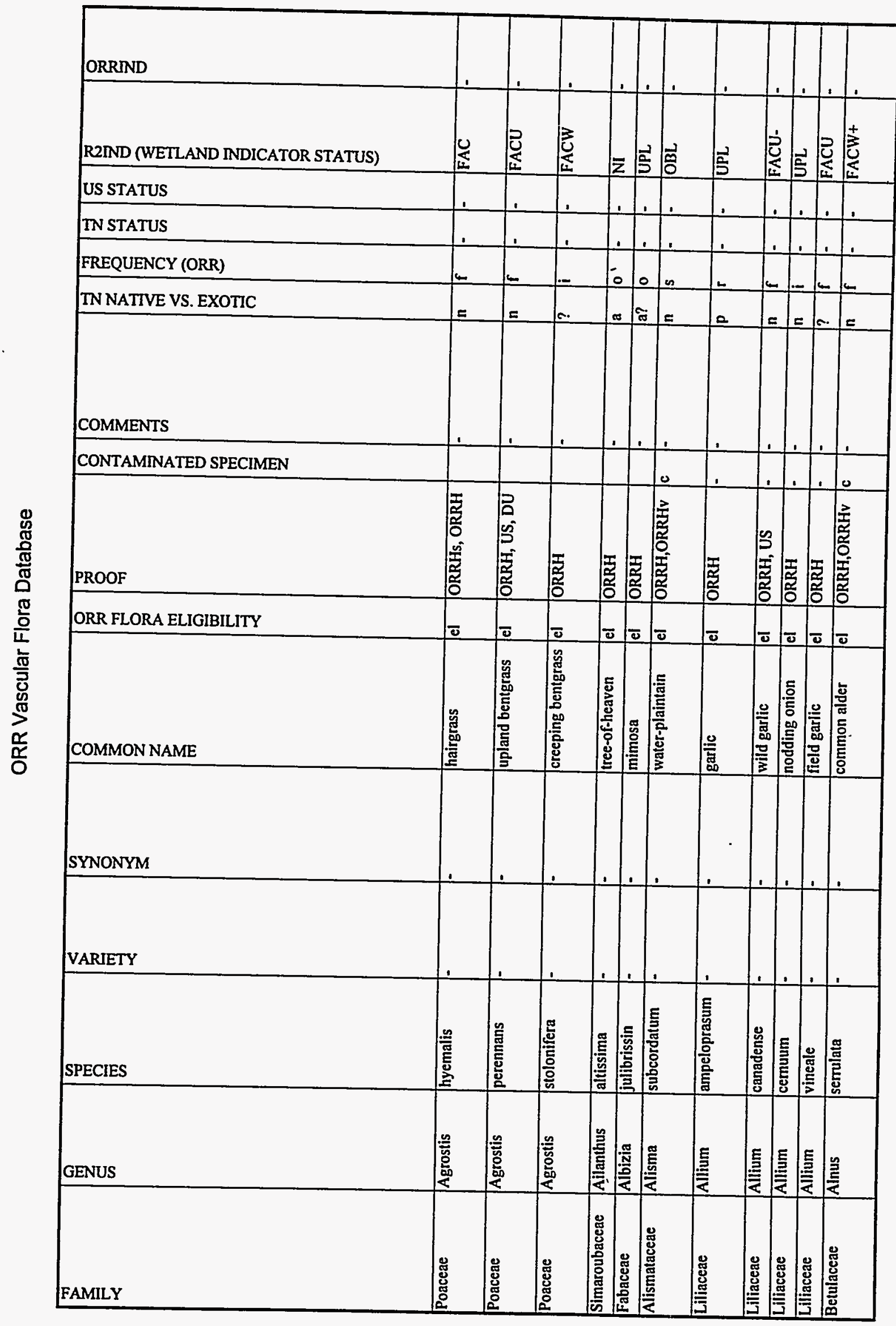


C-15

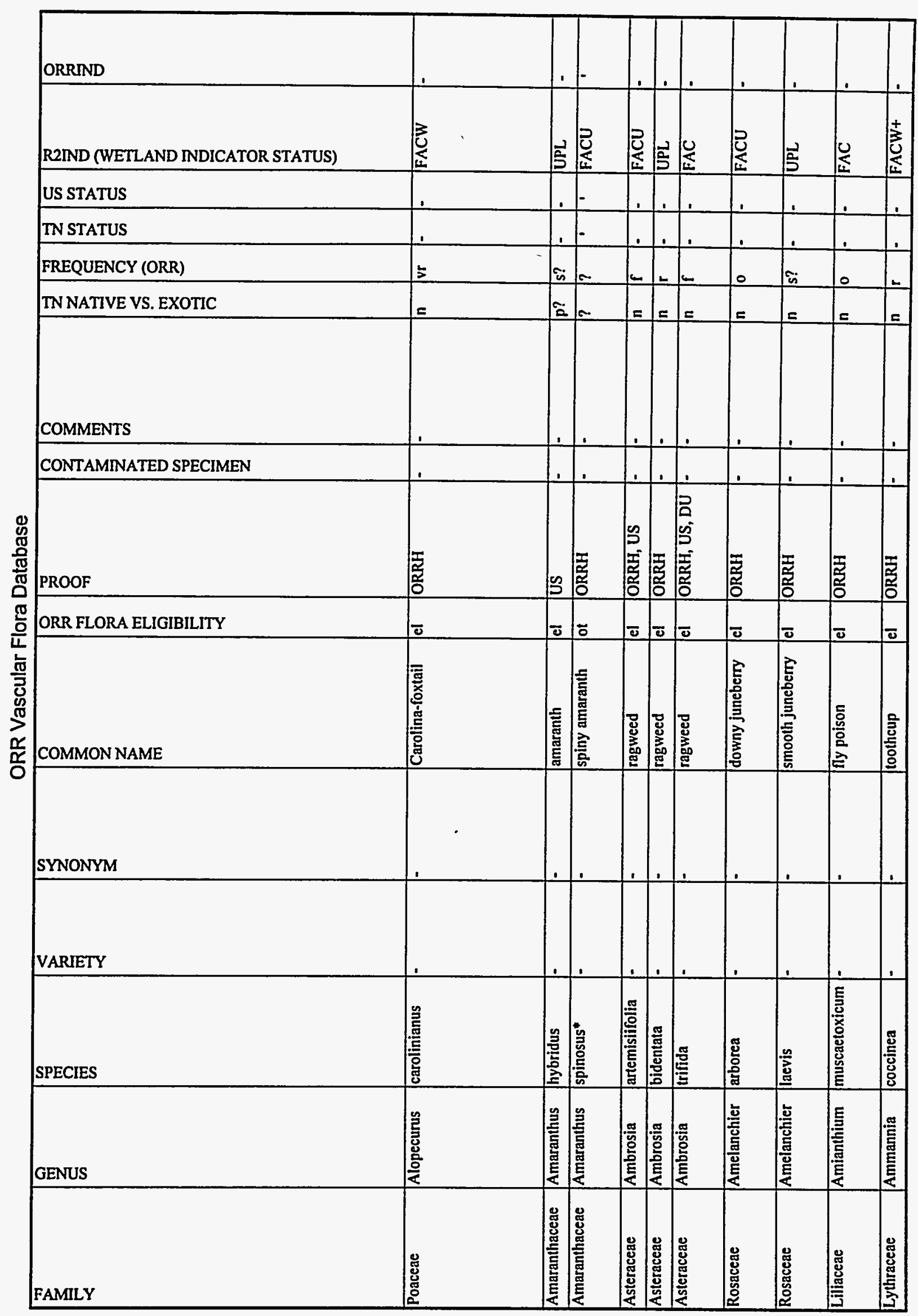




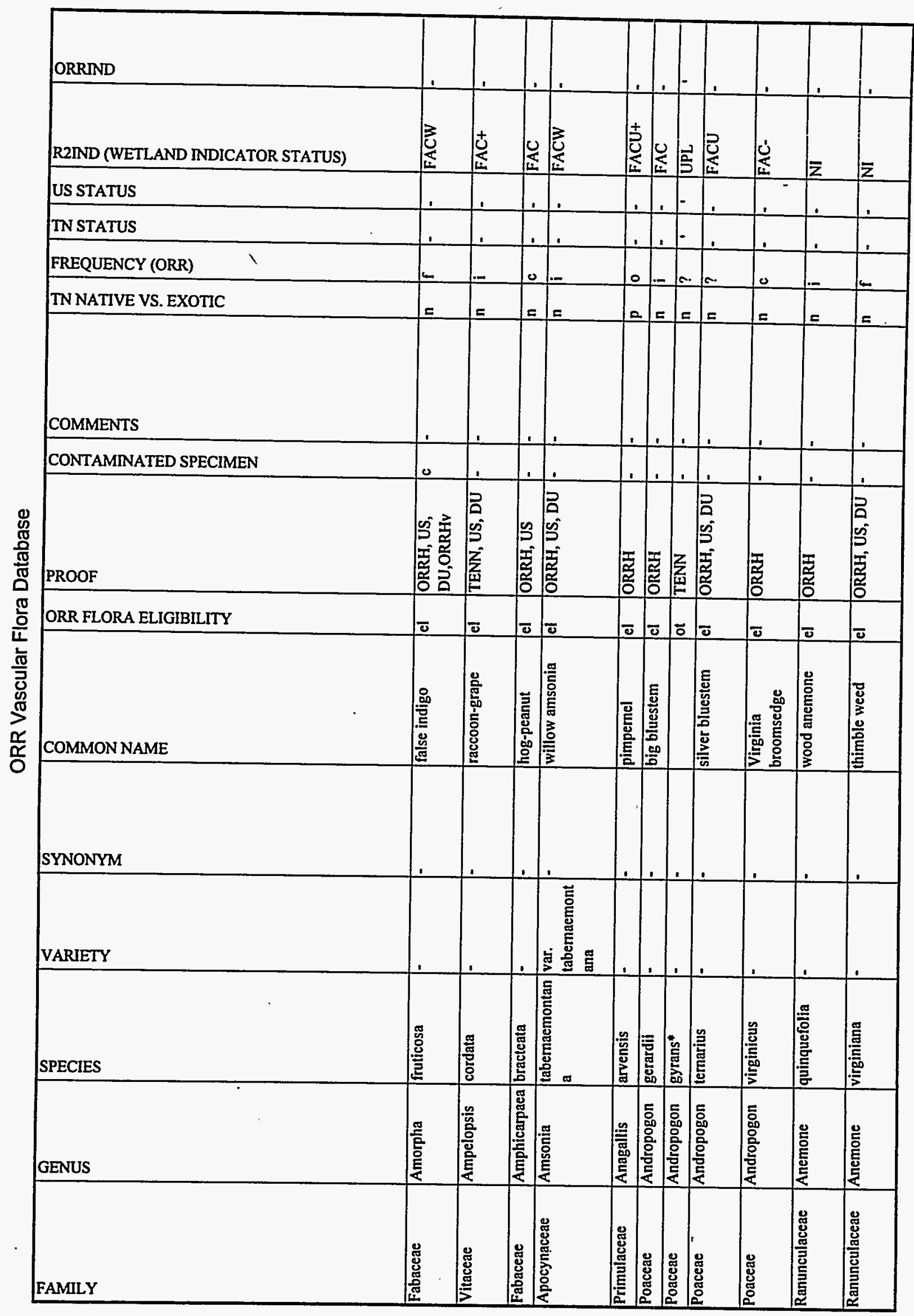




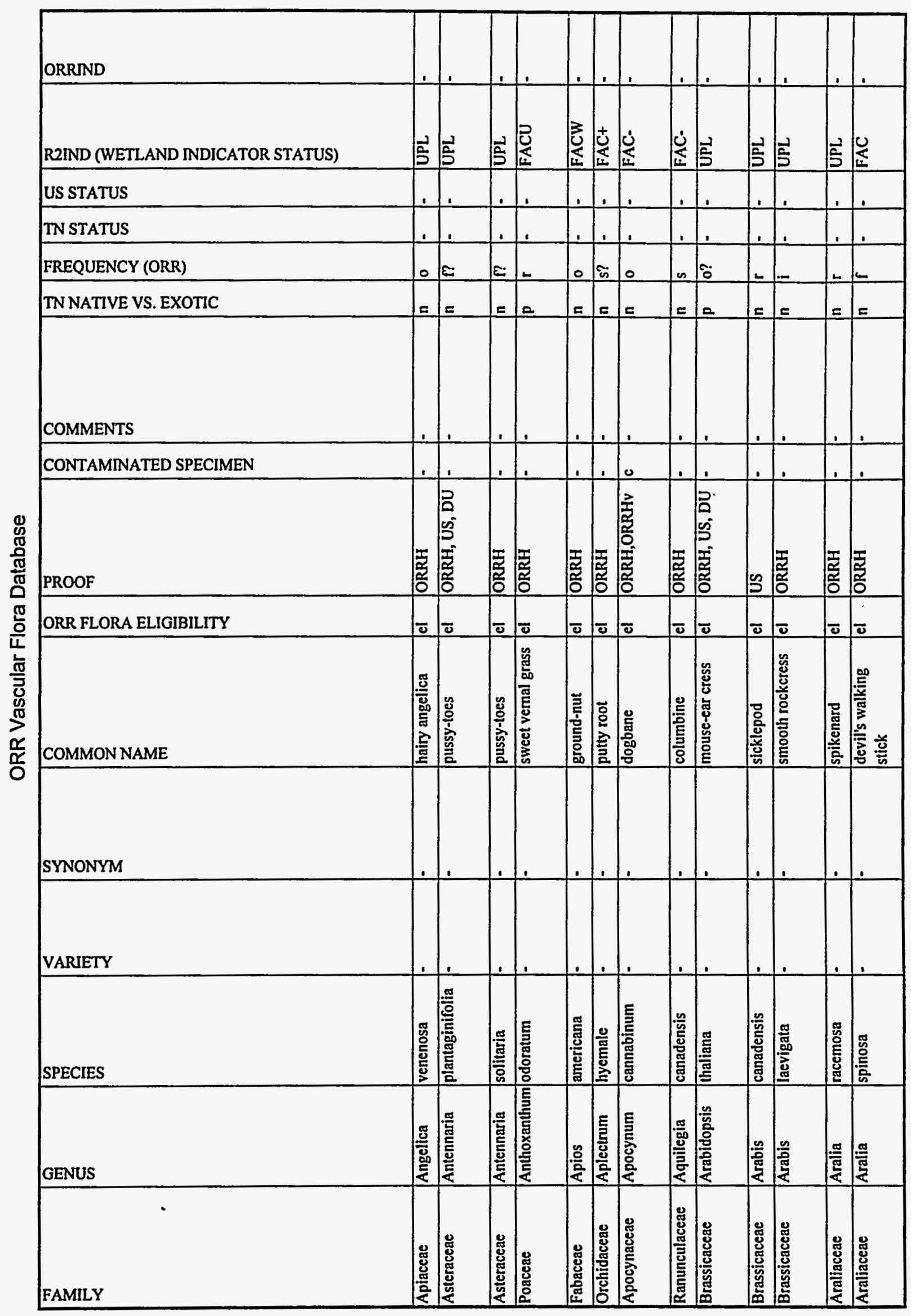




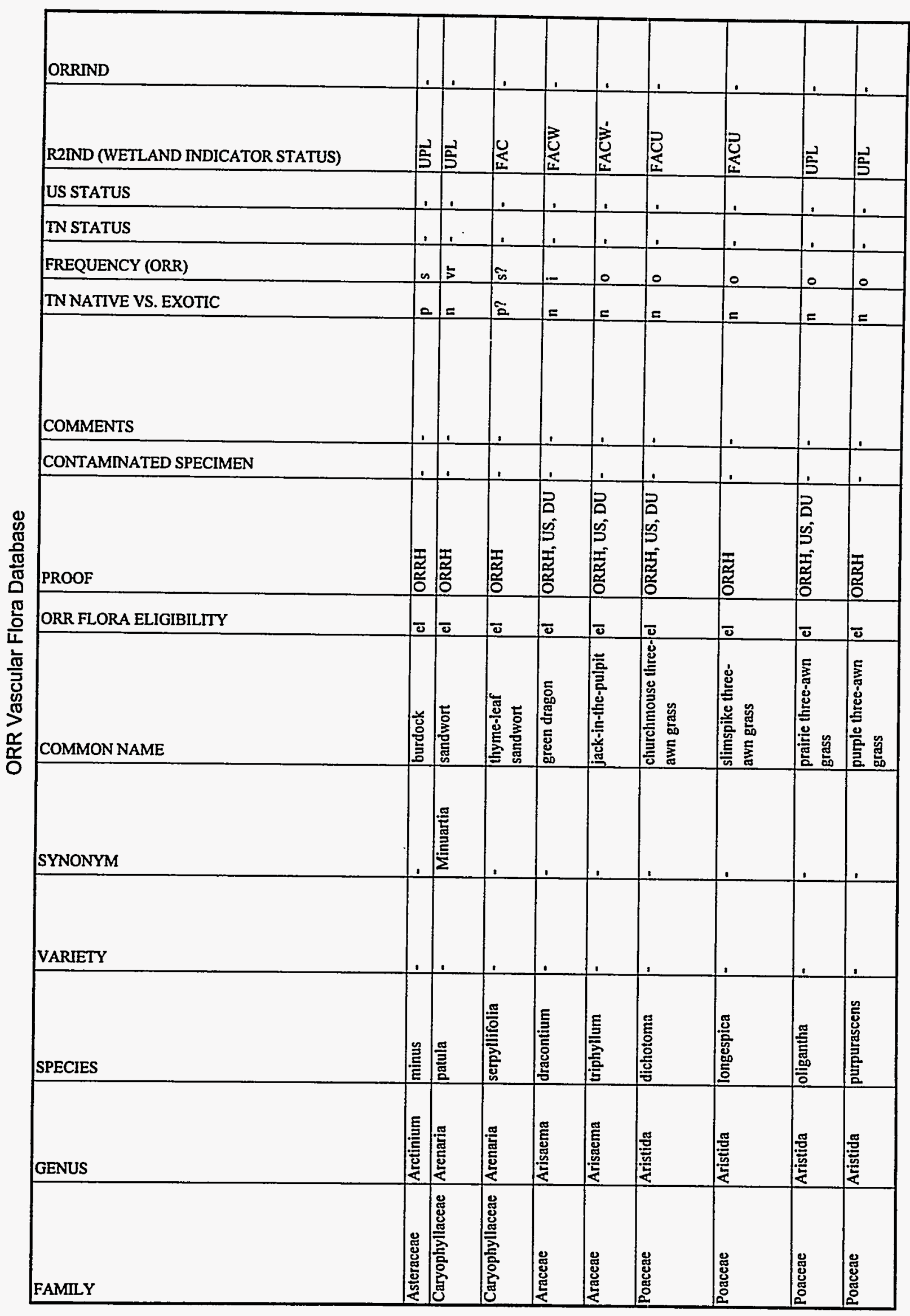




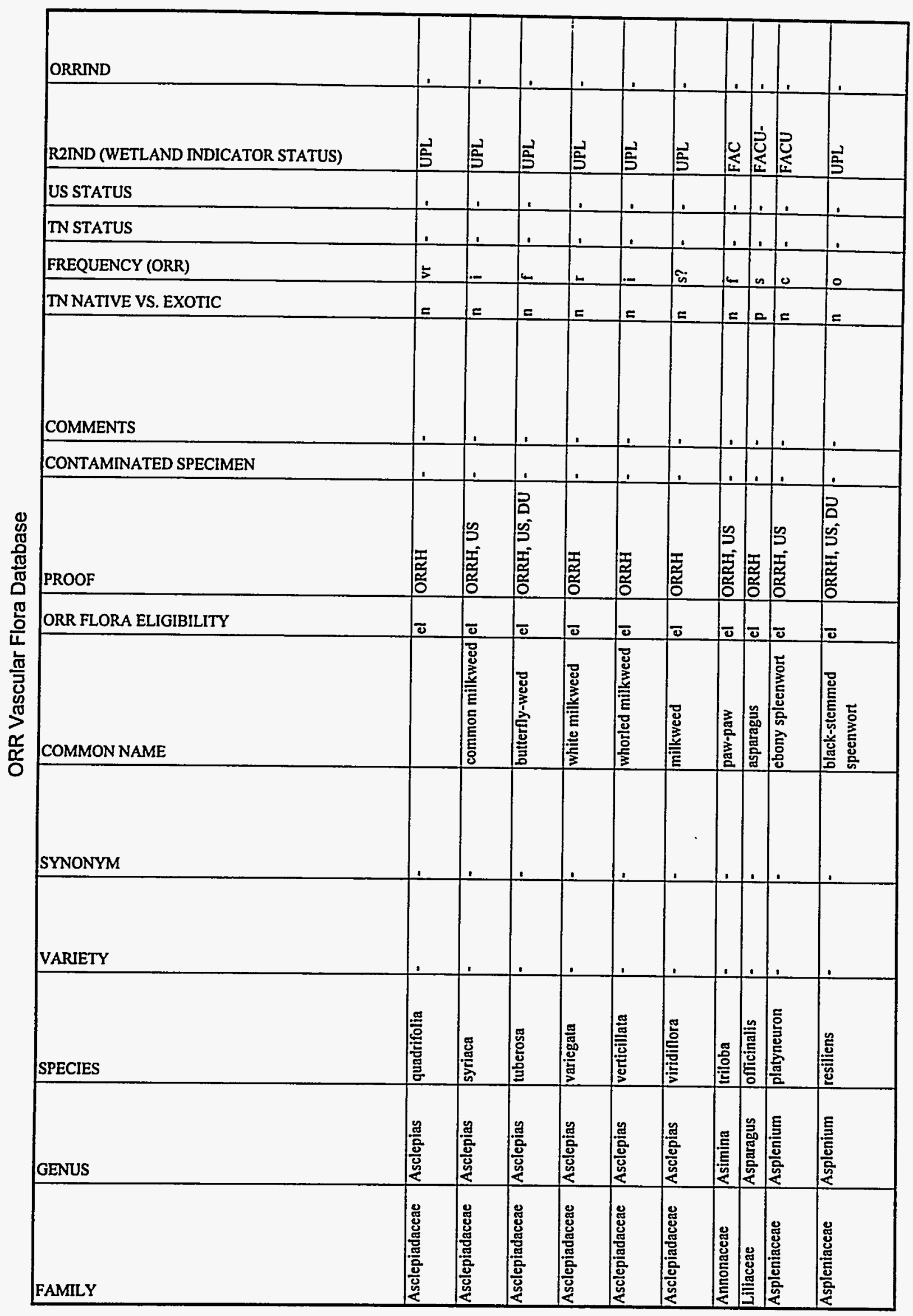




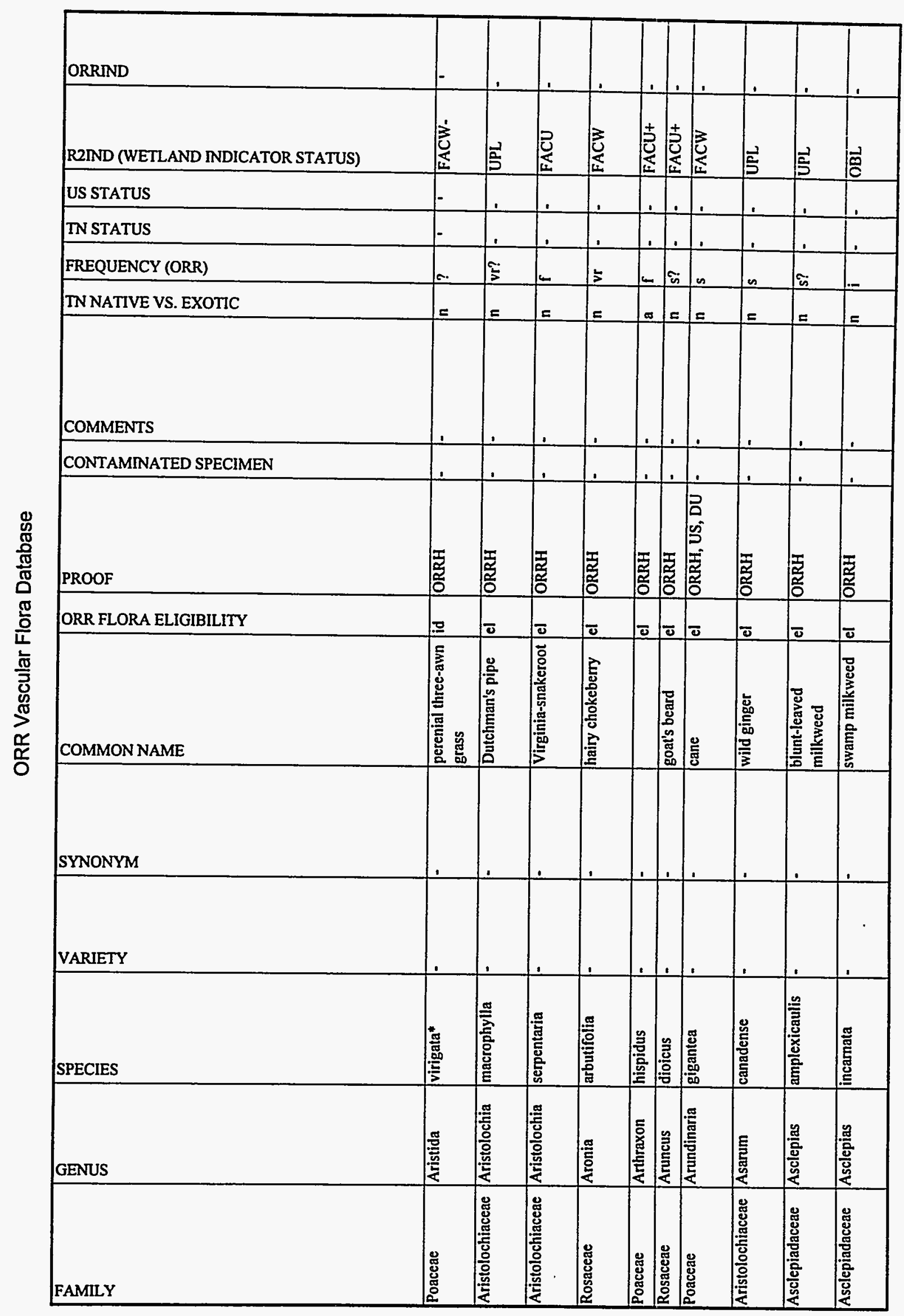




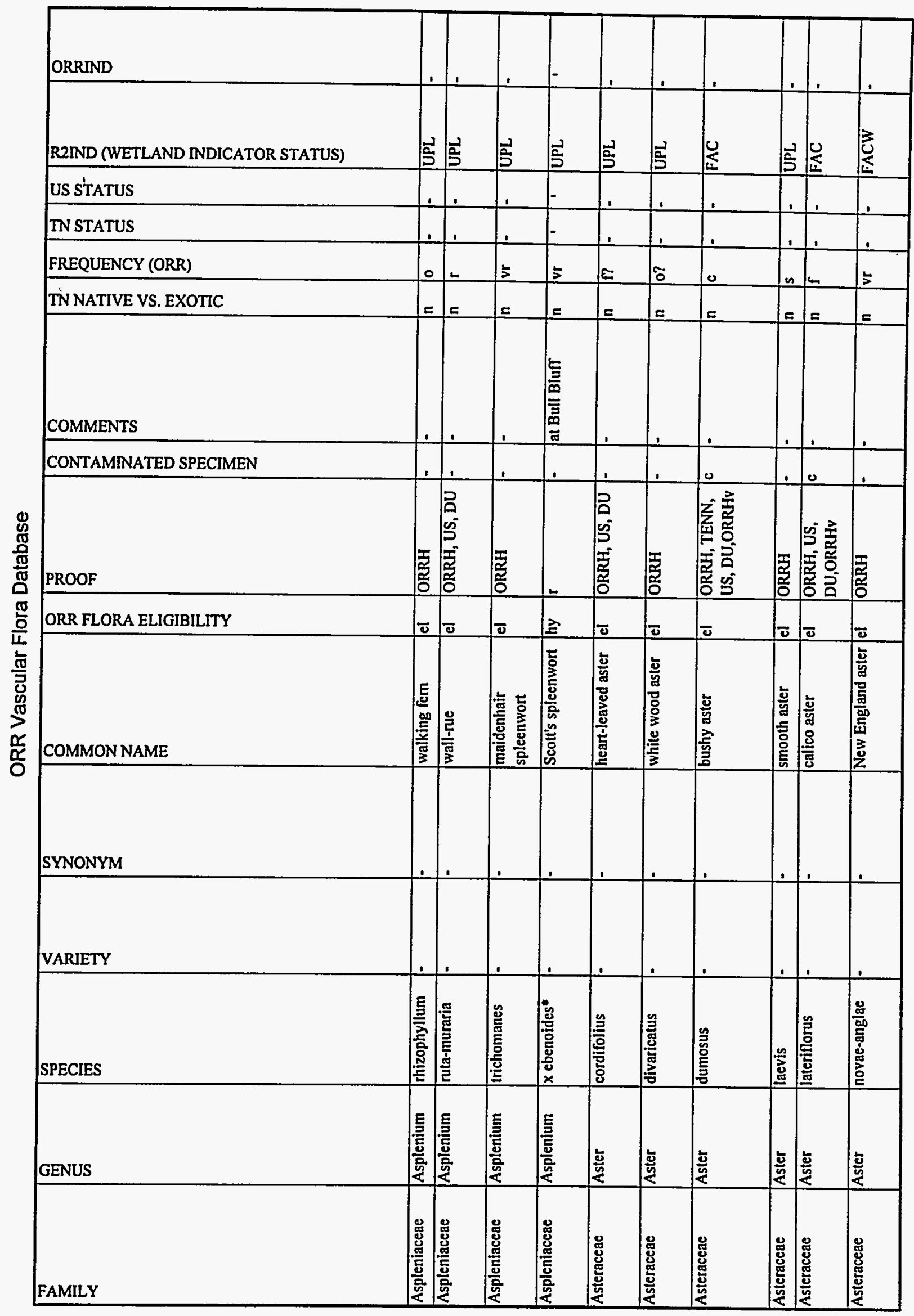




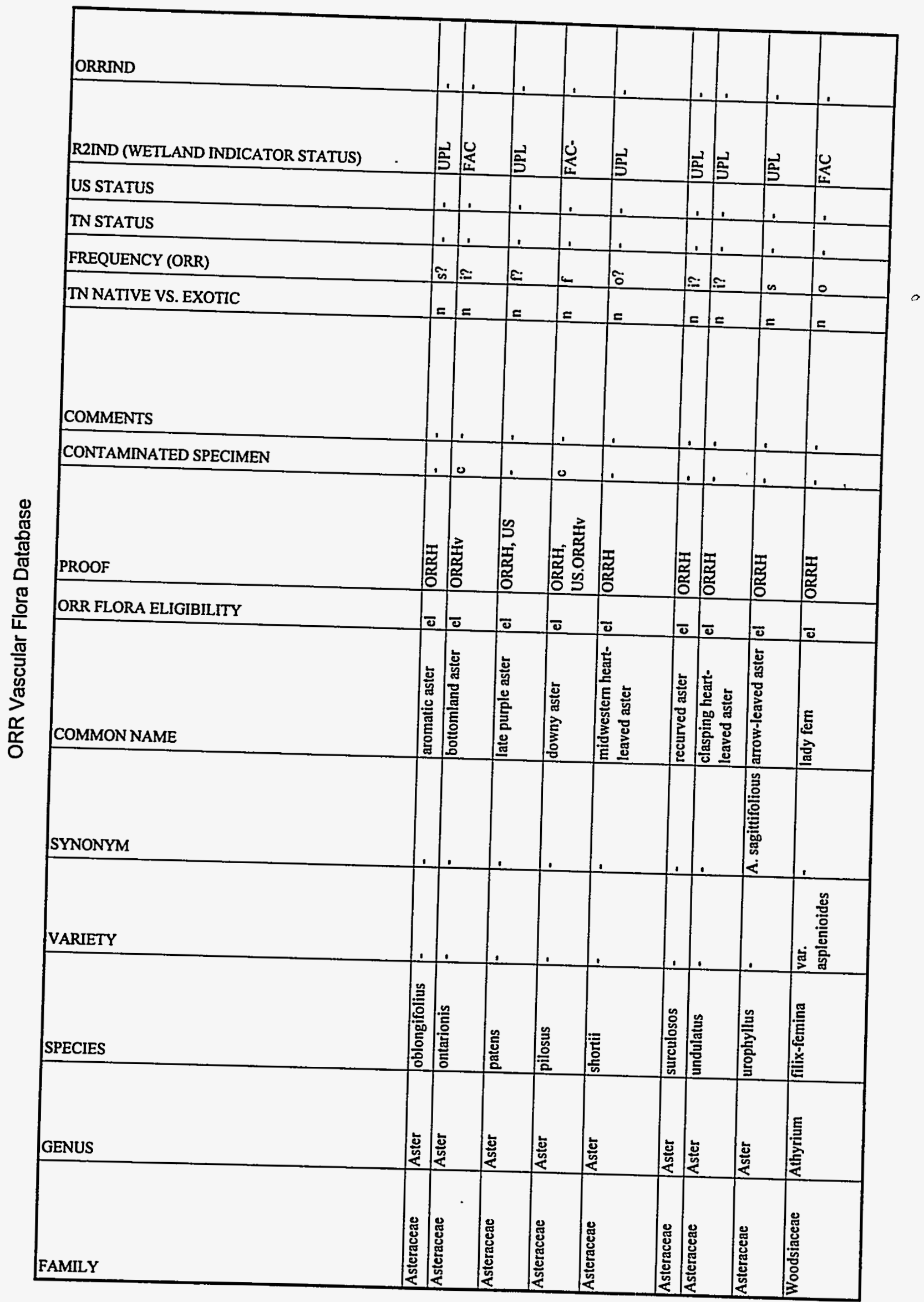




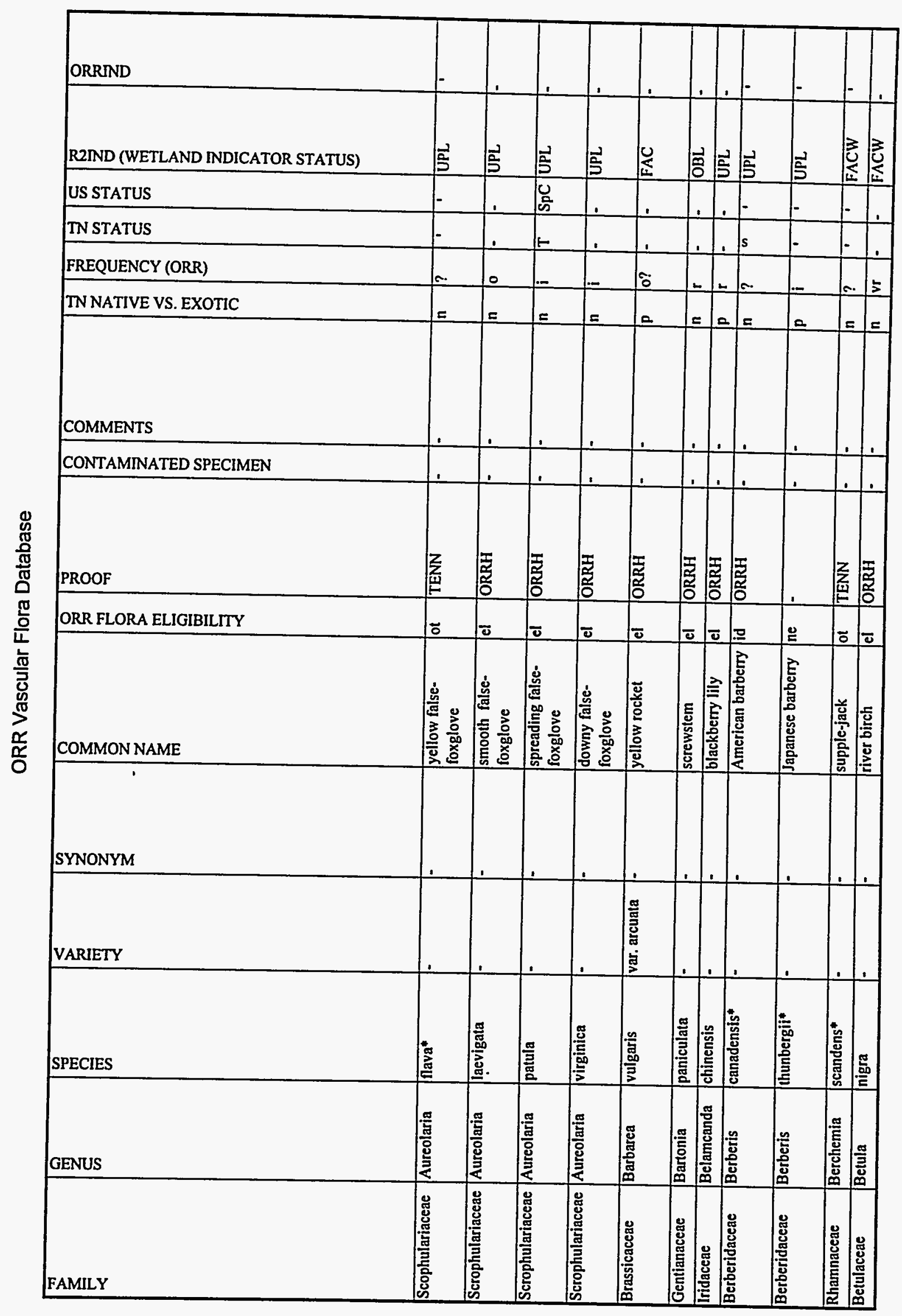




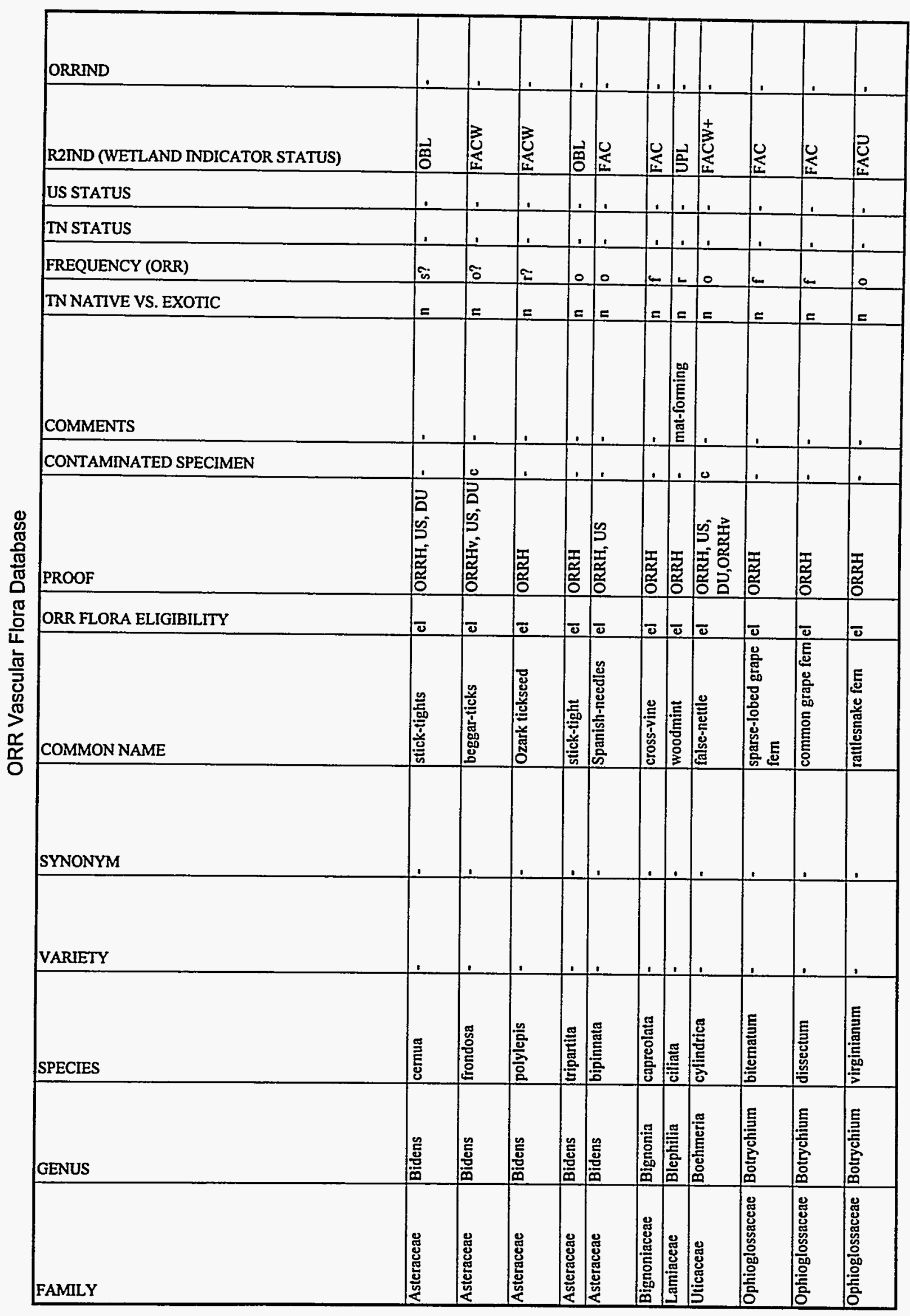




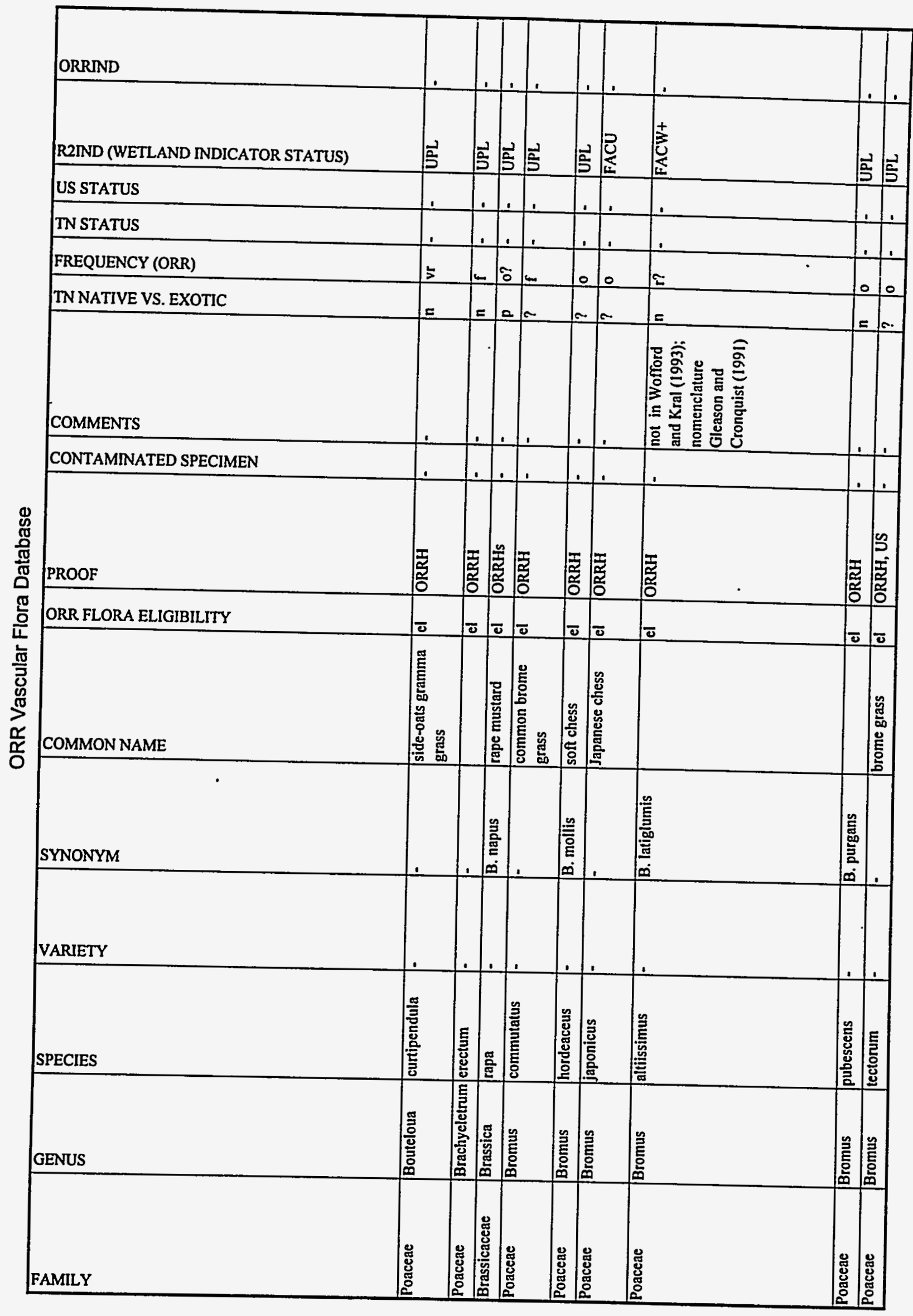




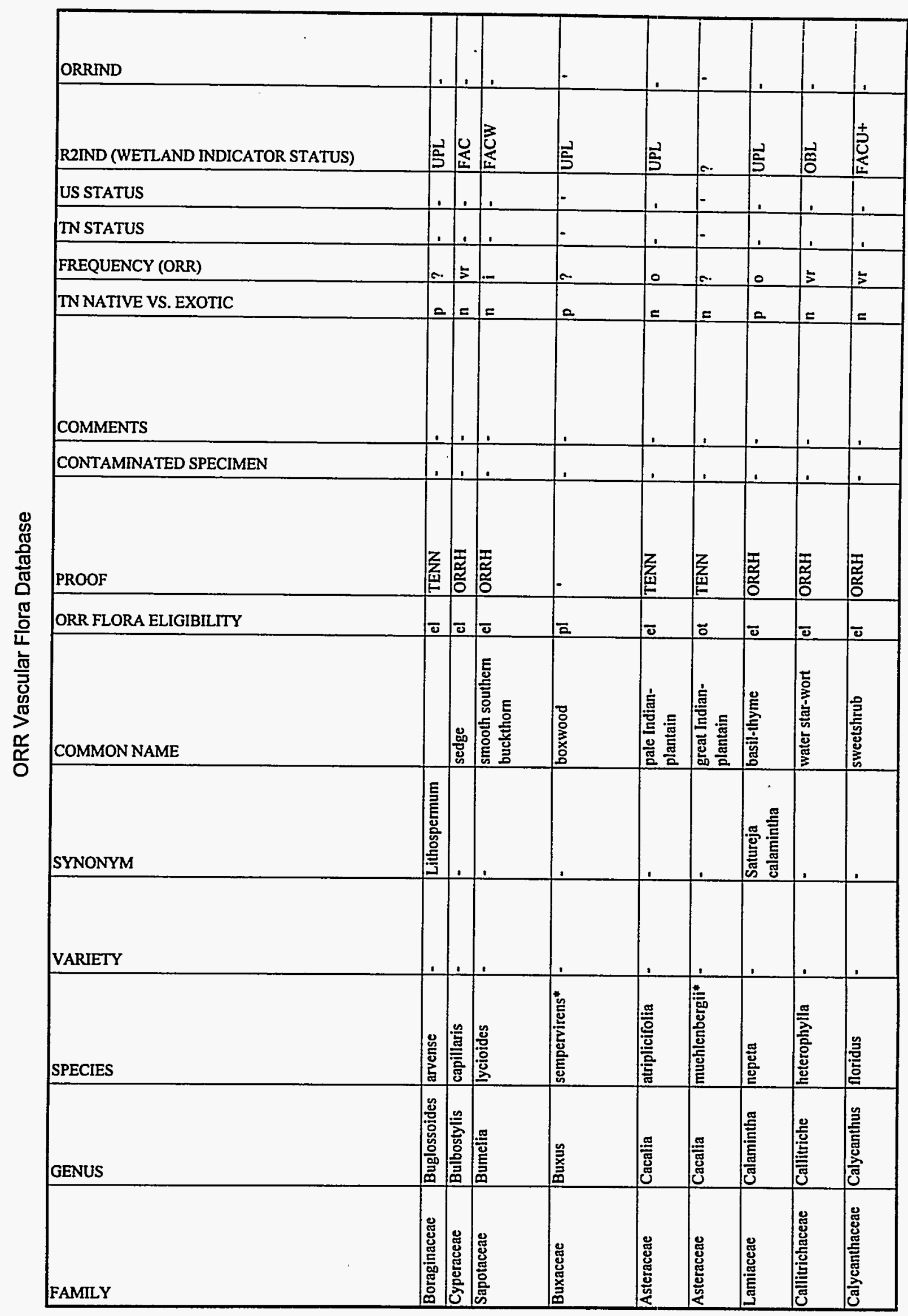




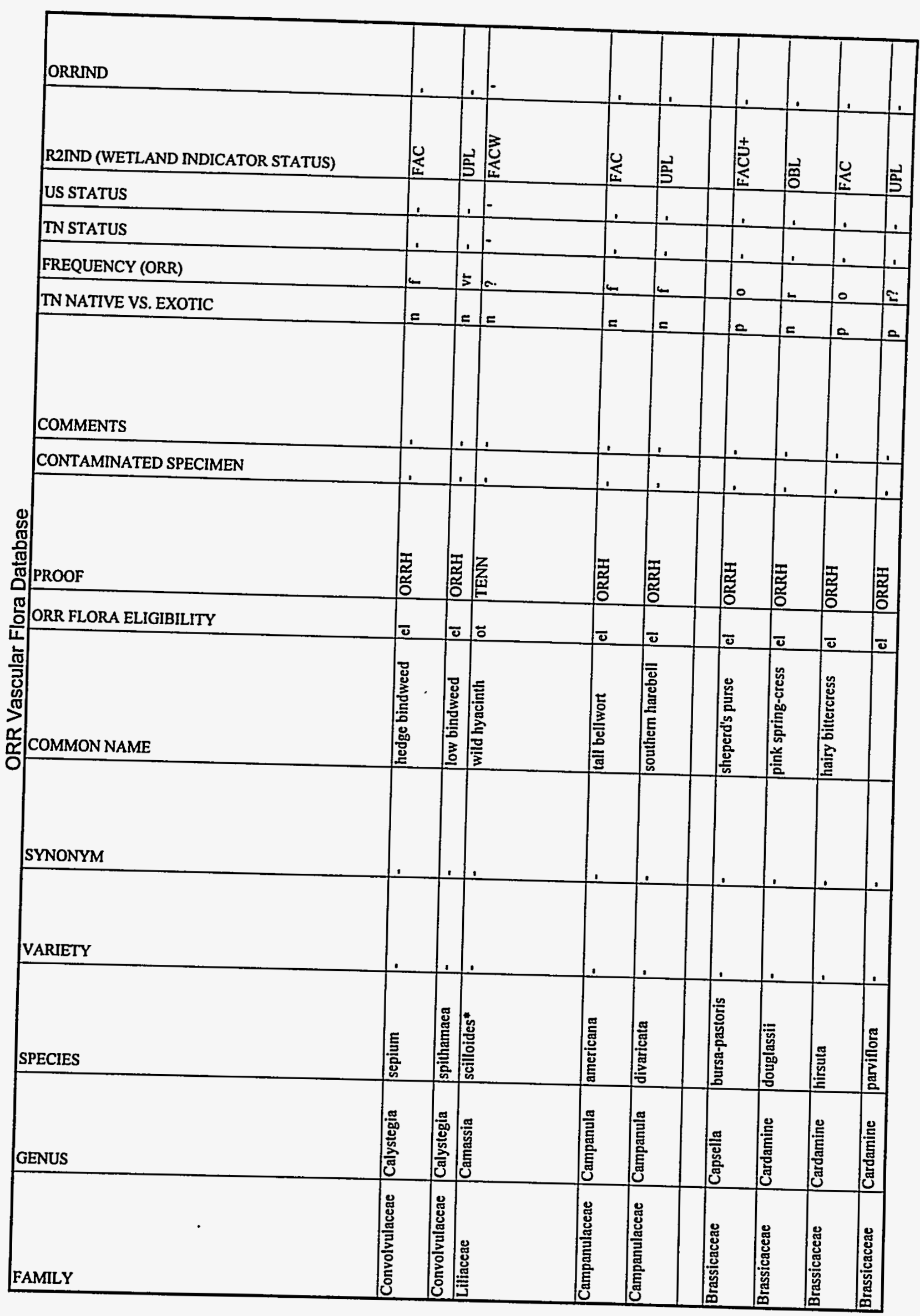




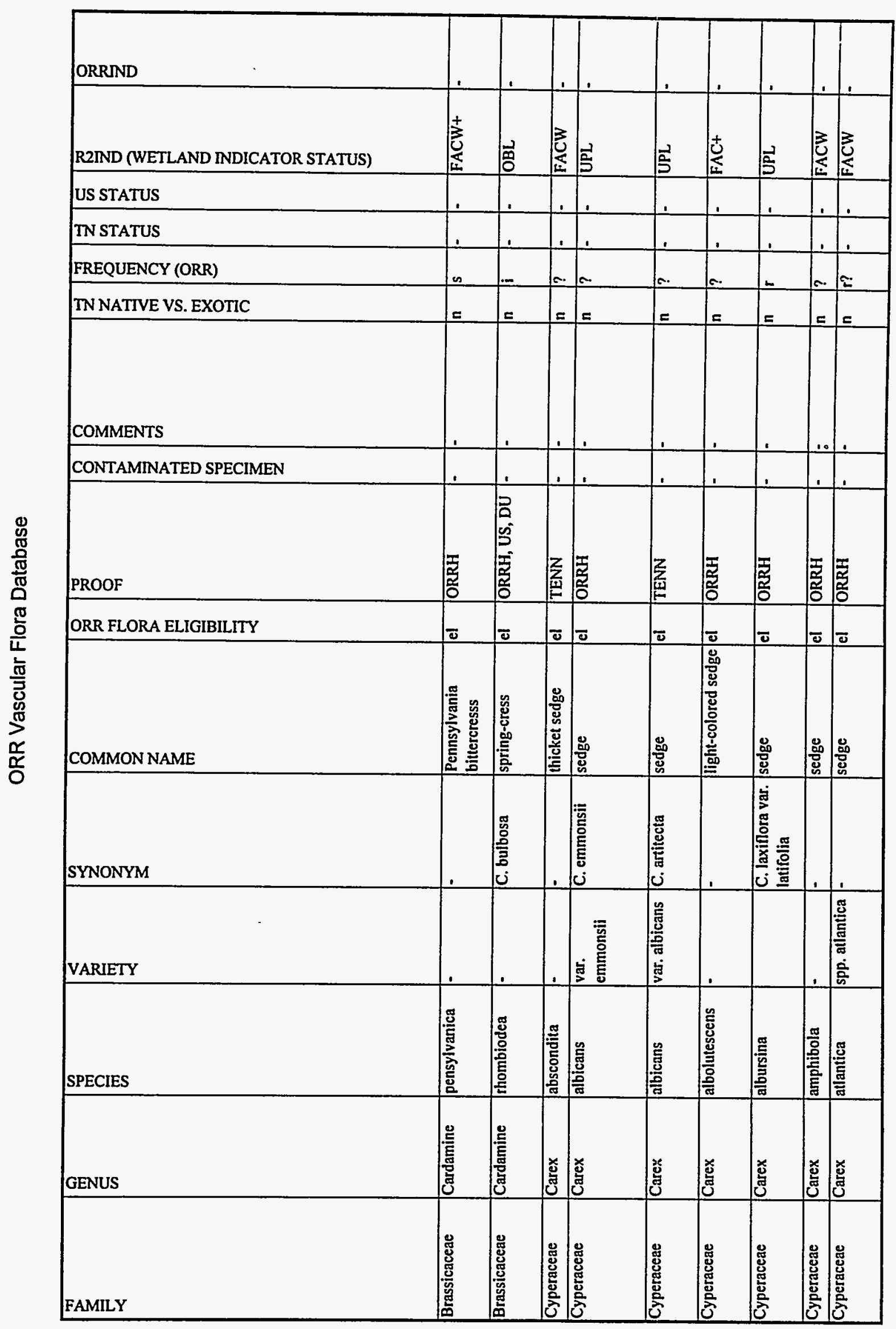




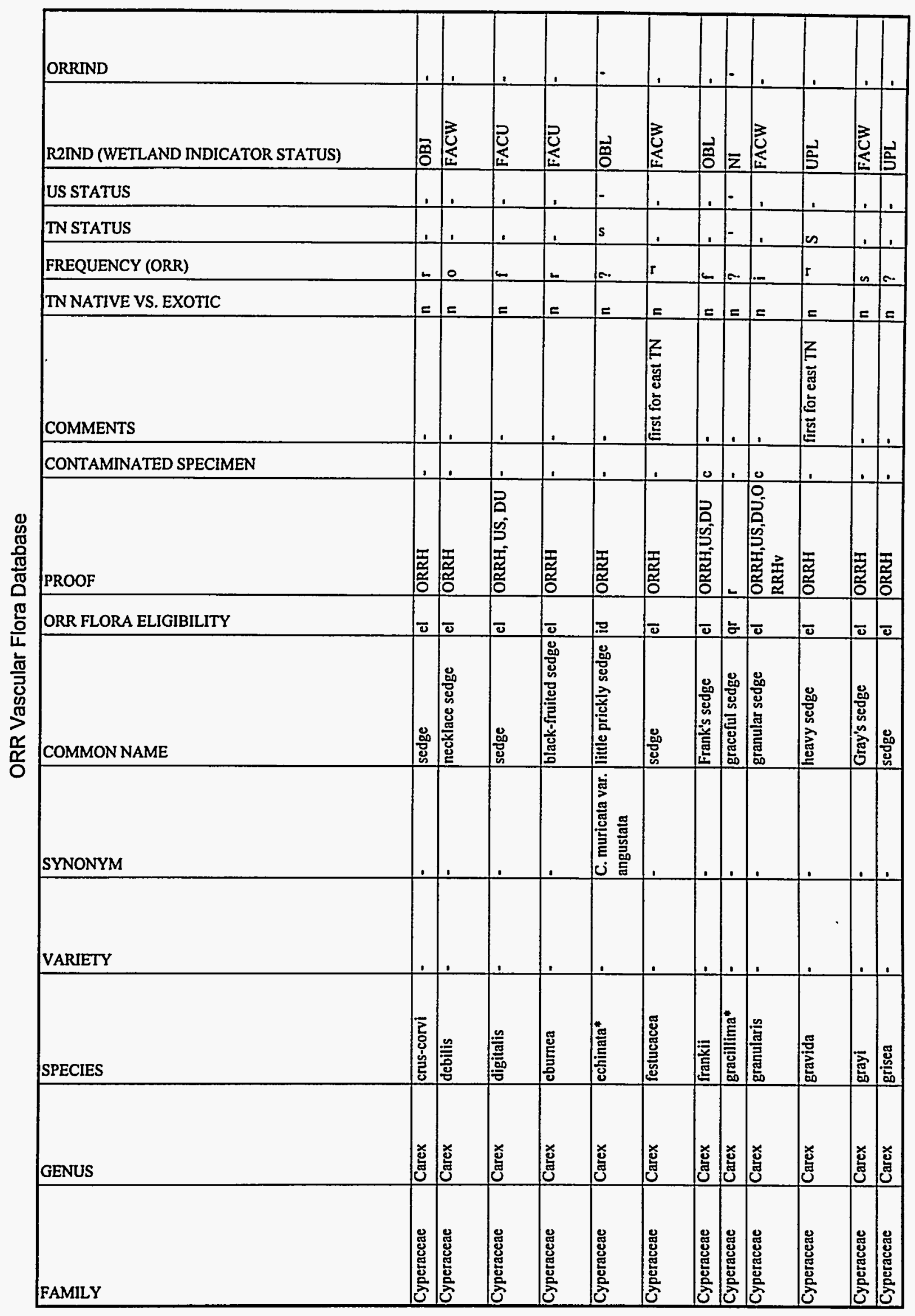




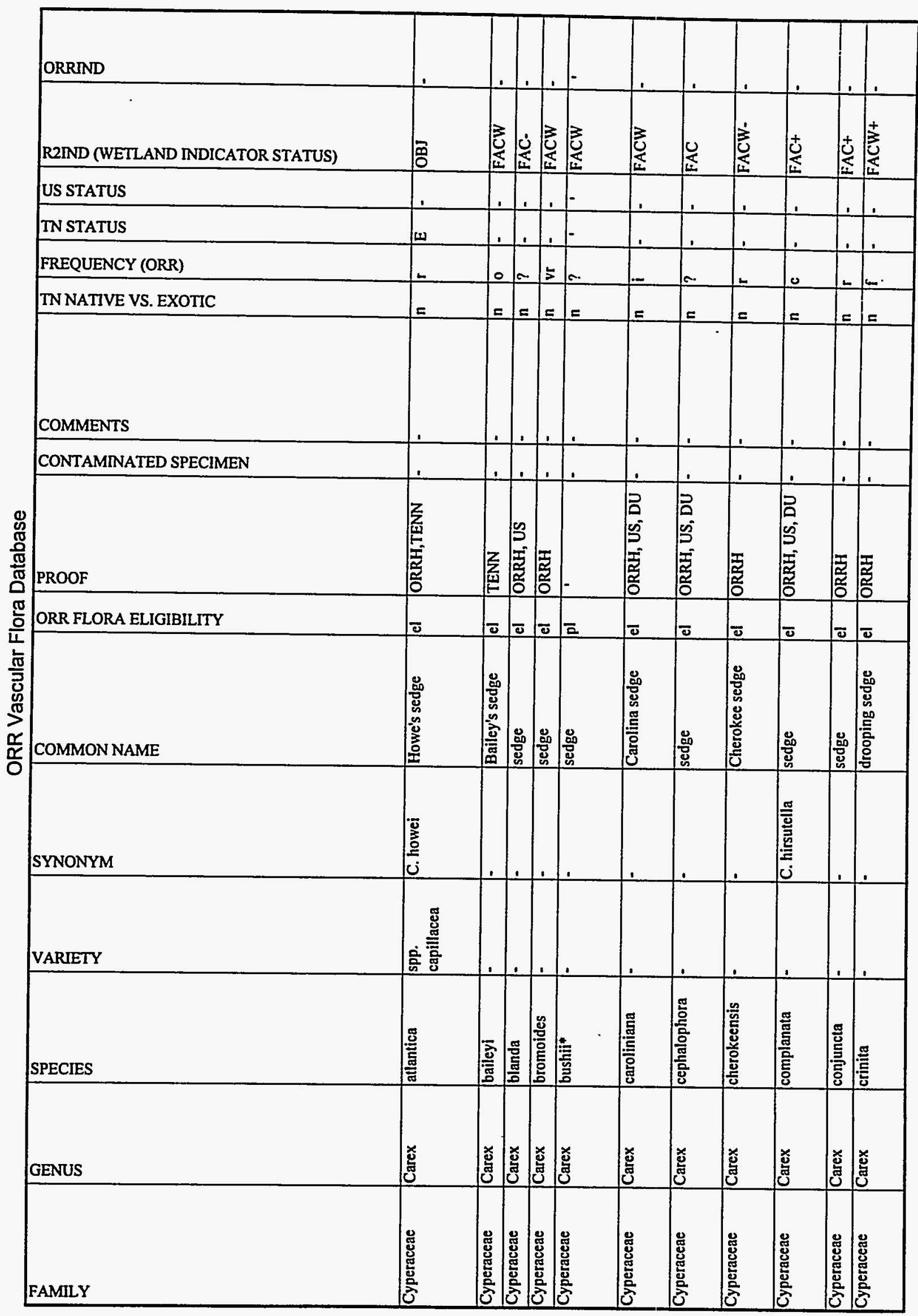




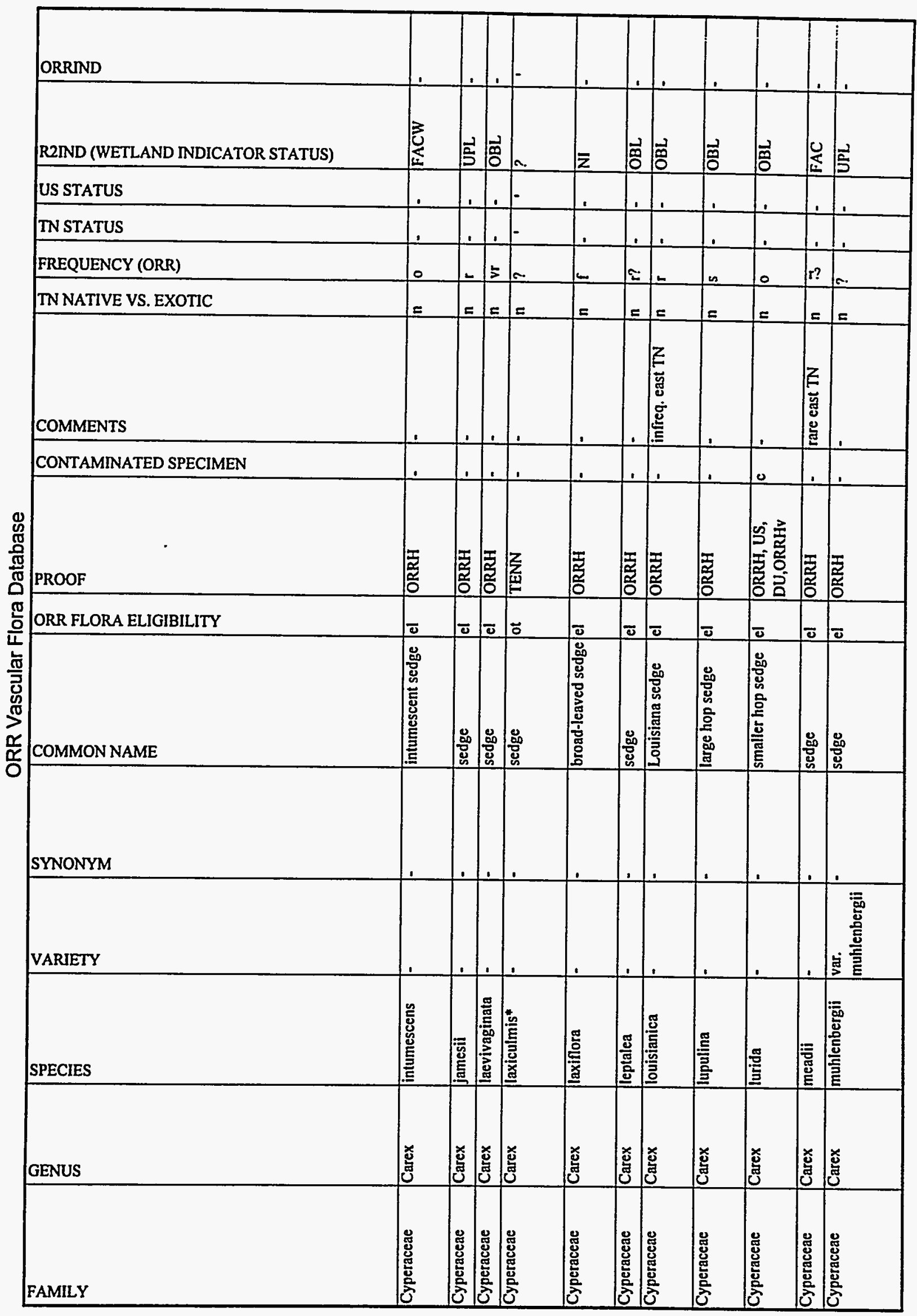




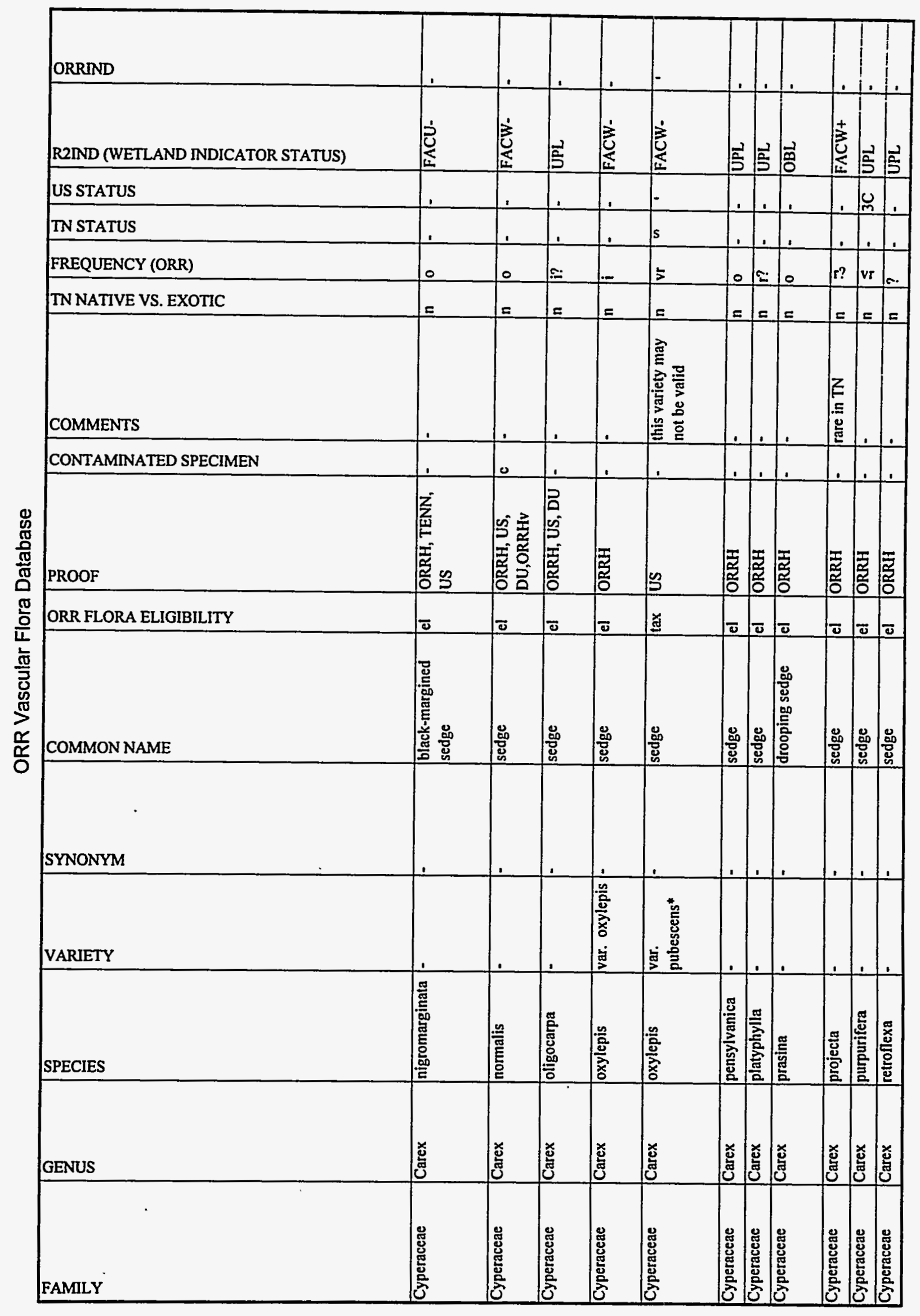




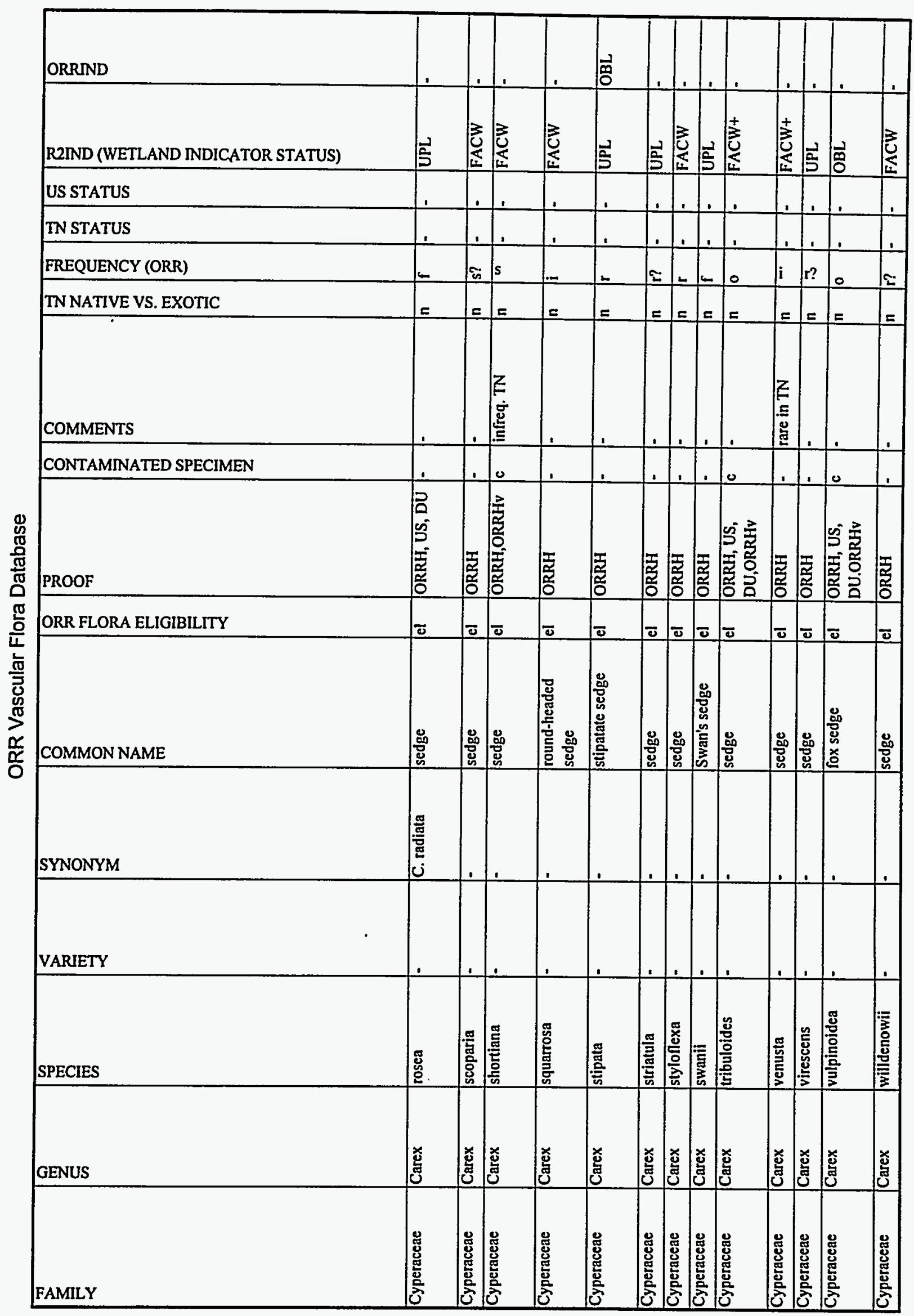




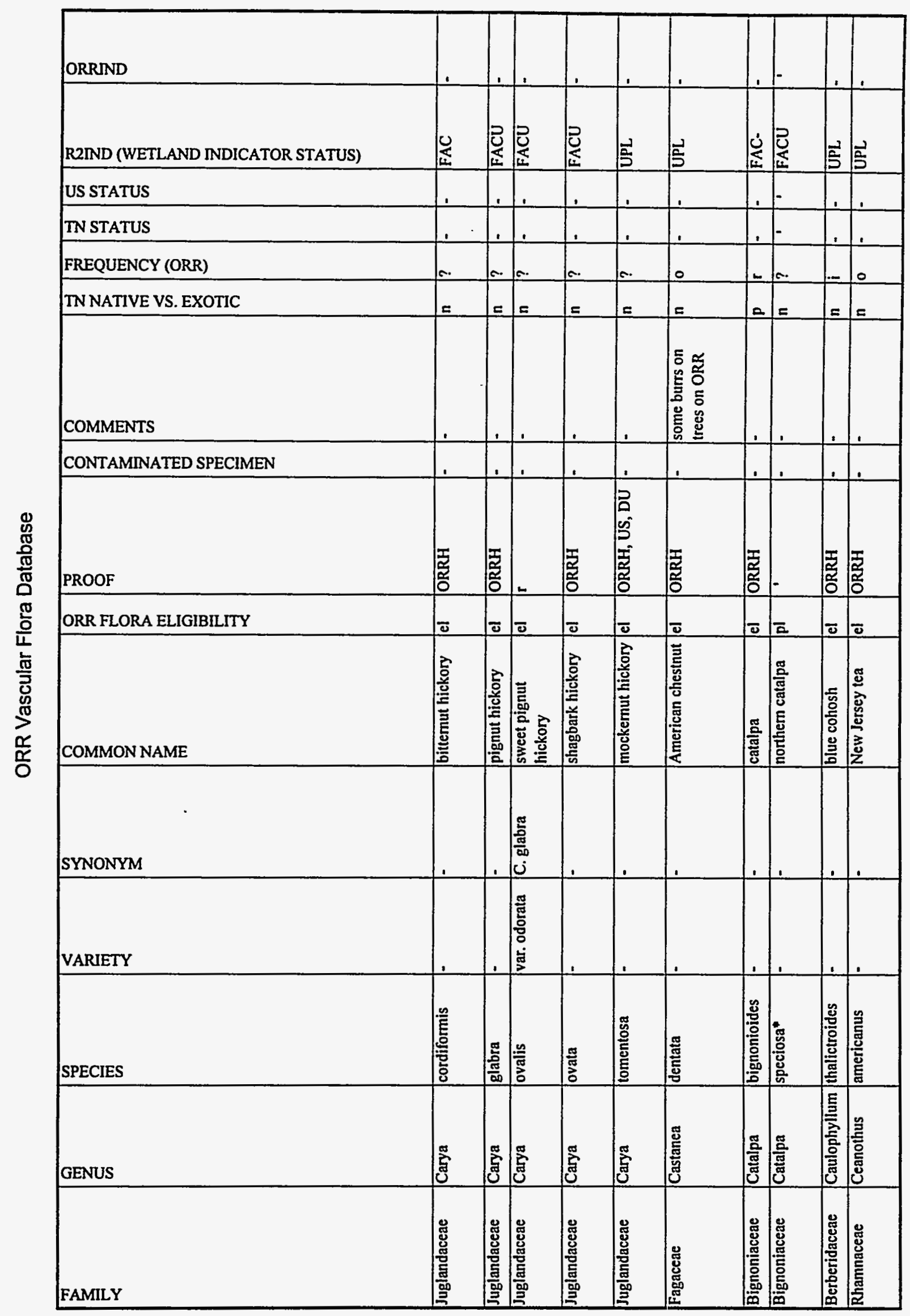




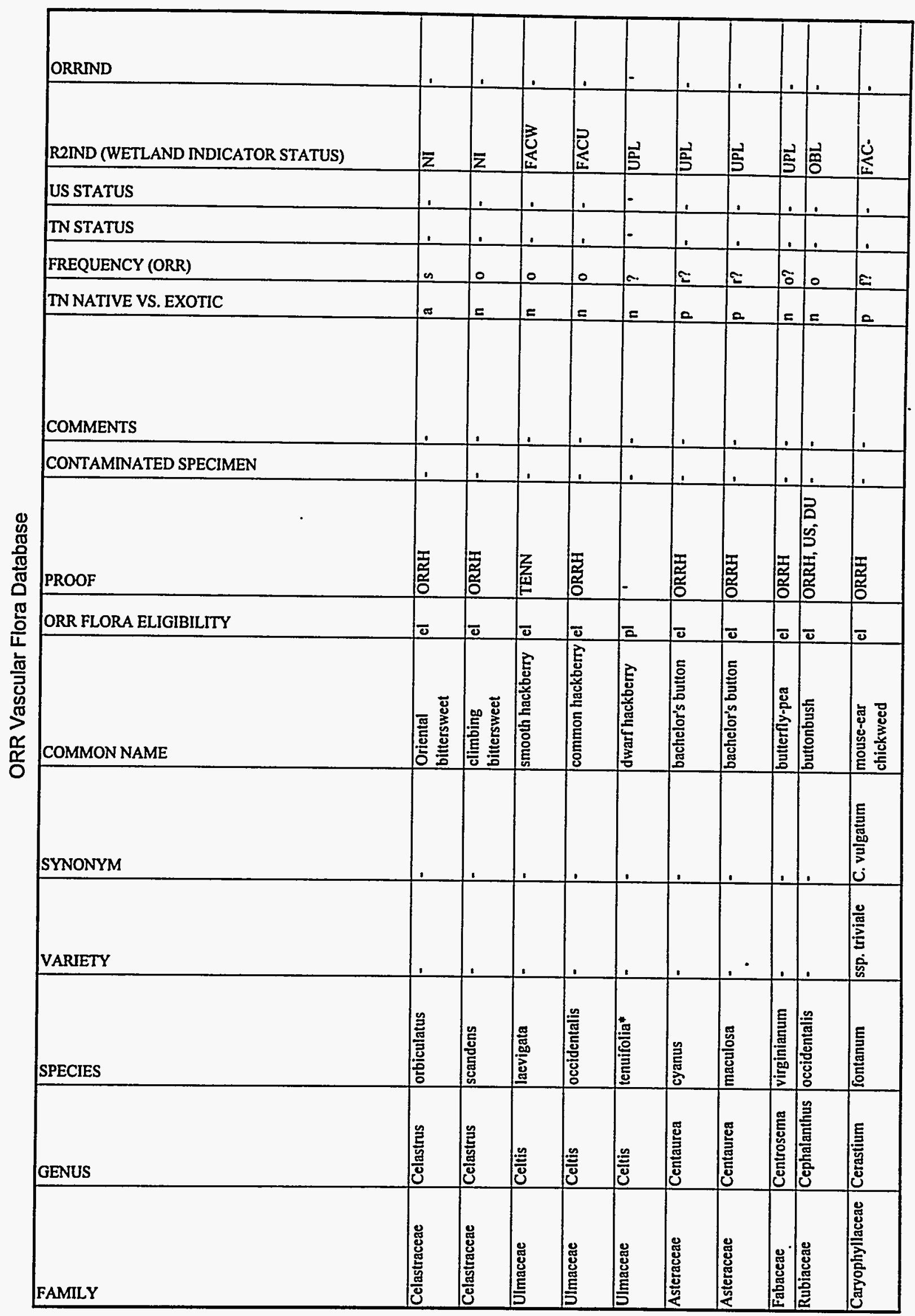




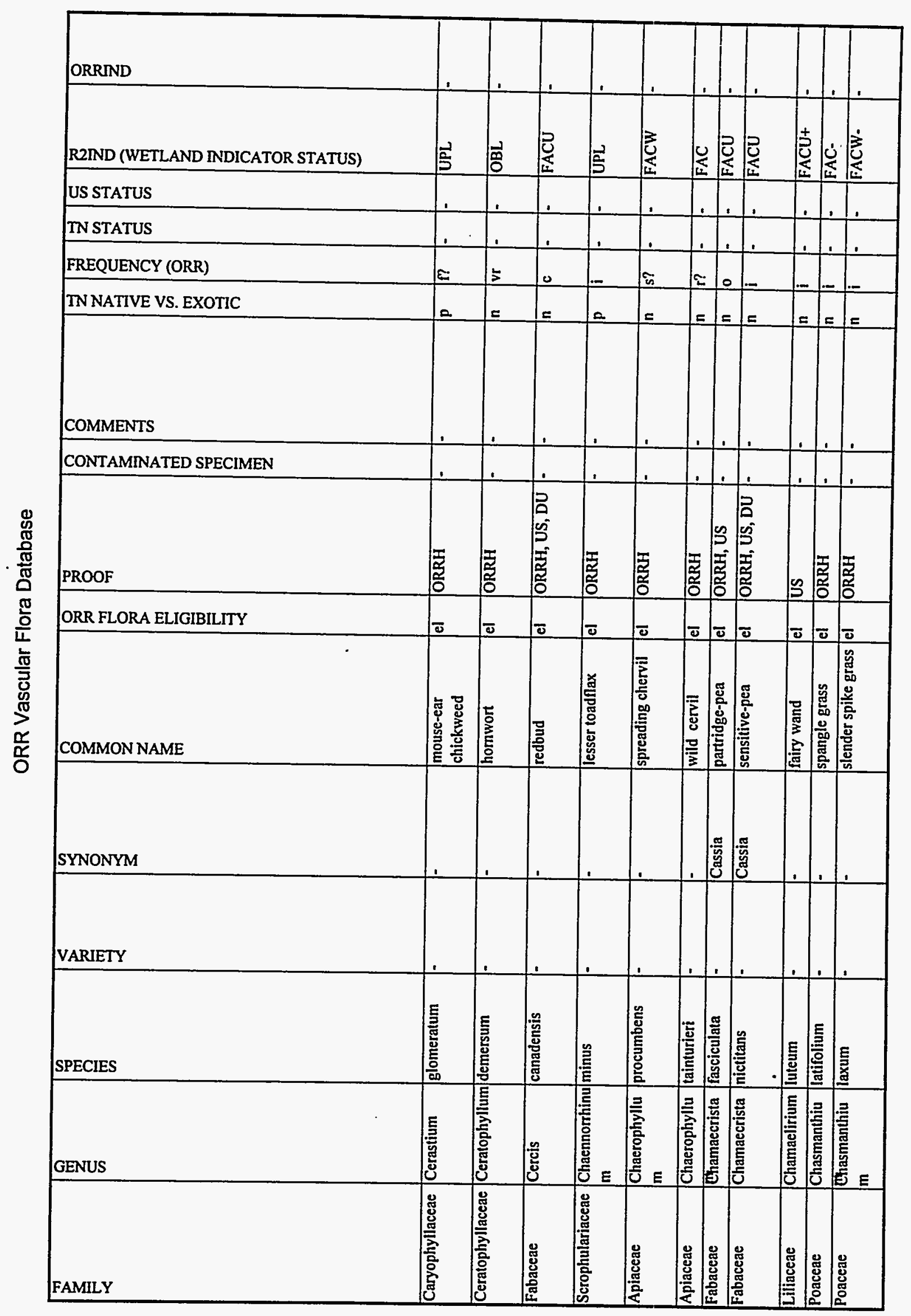




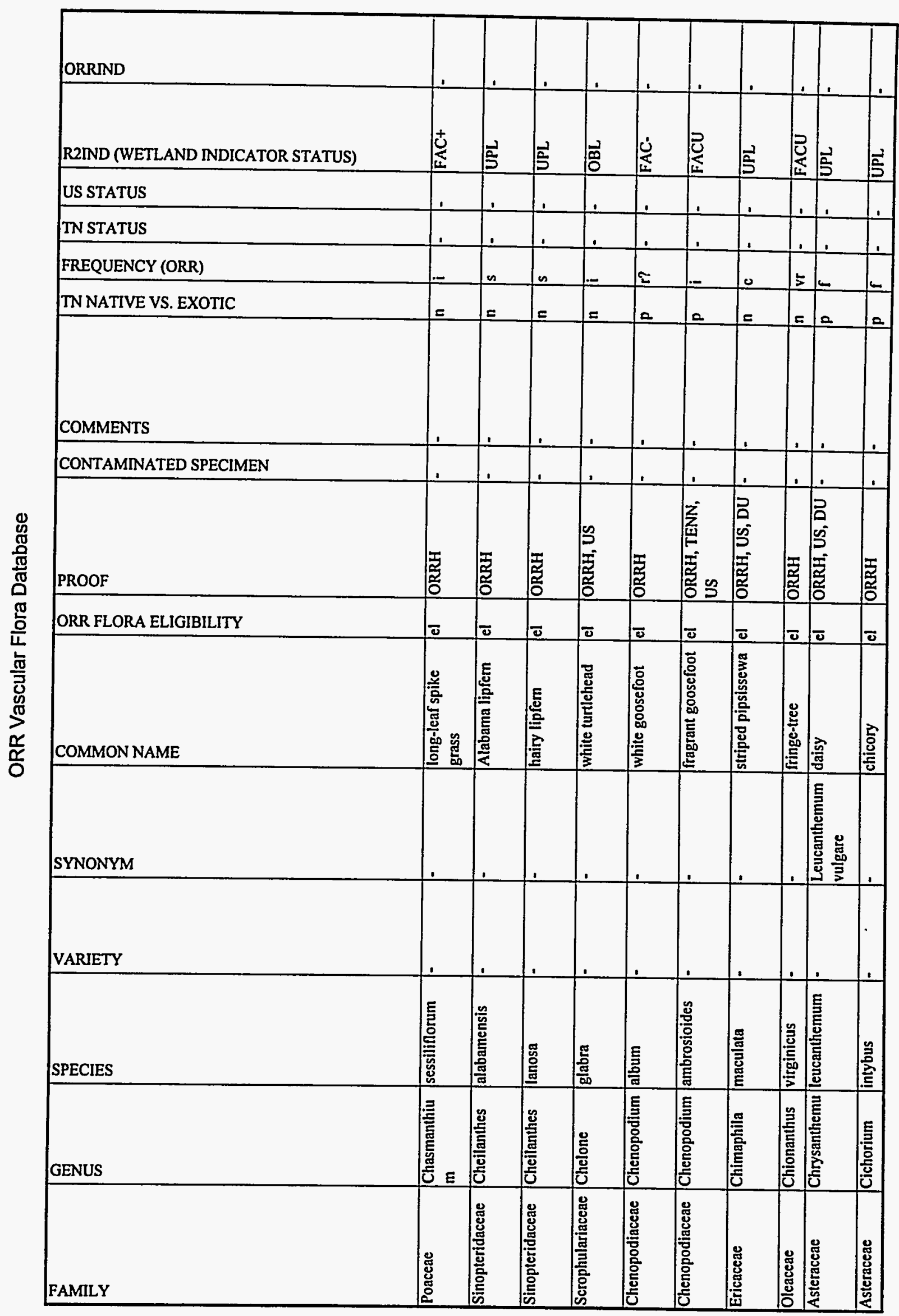




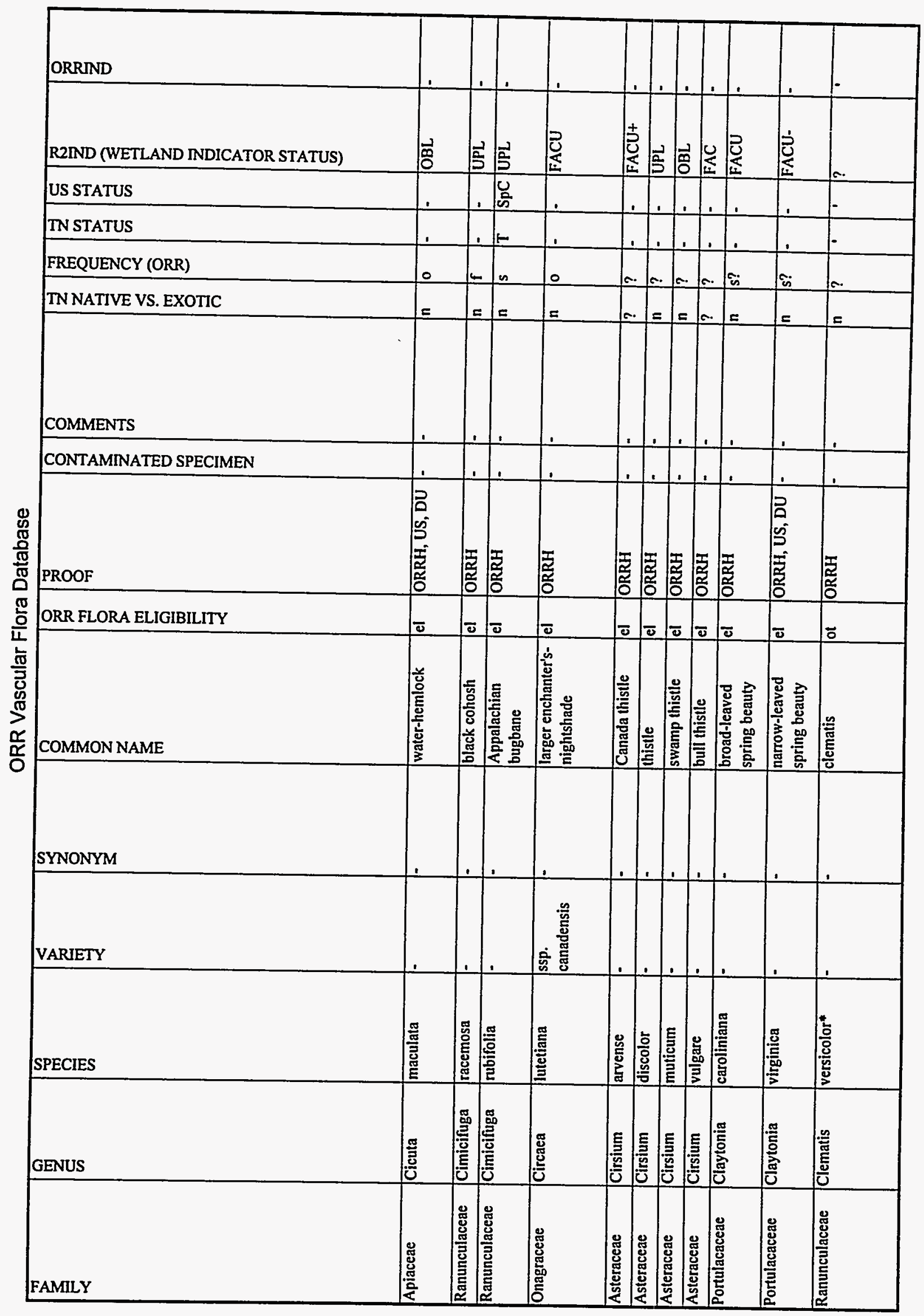




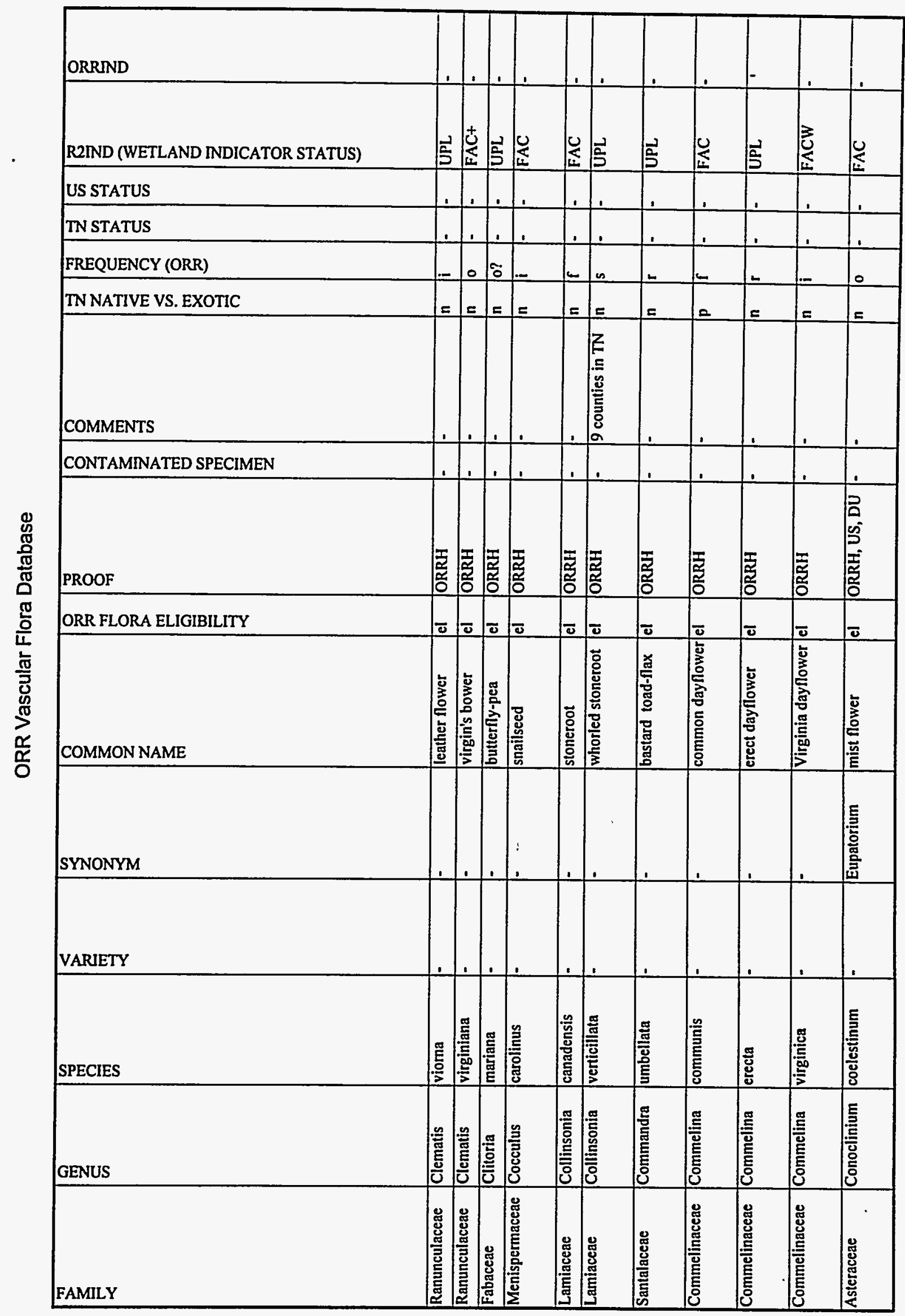




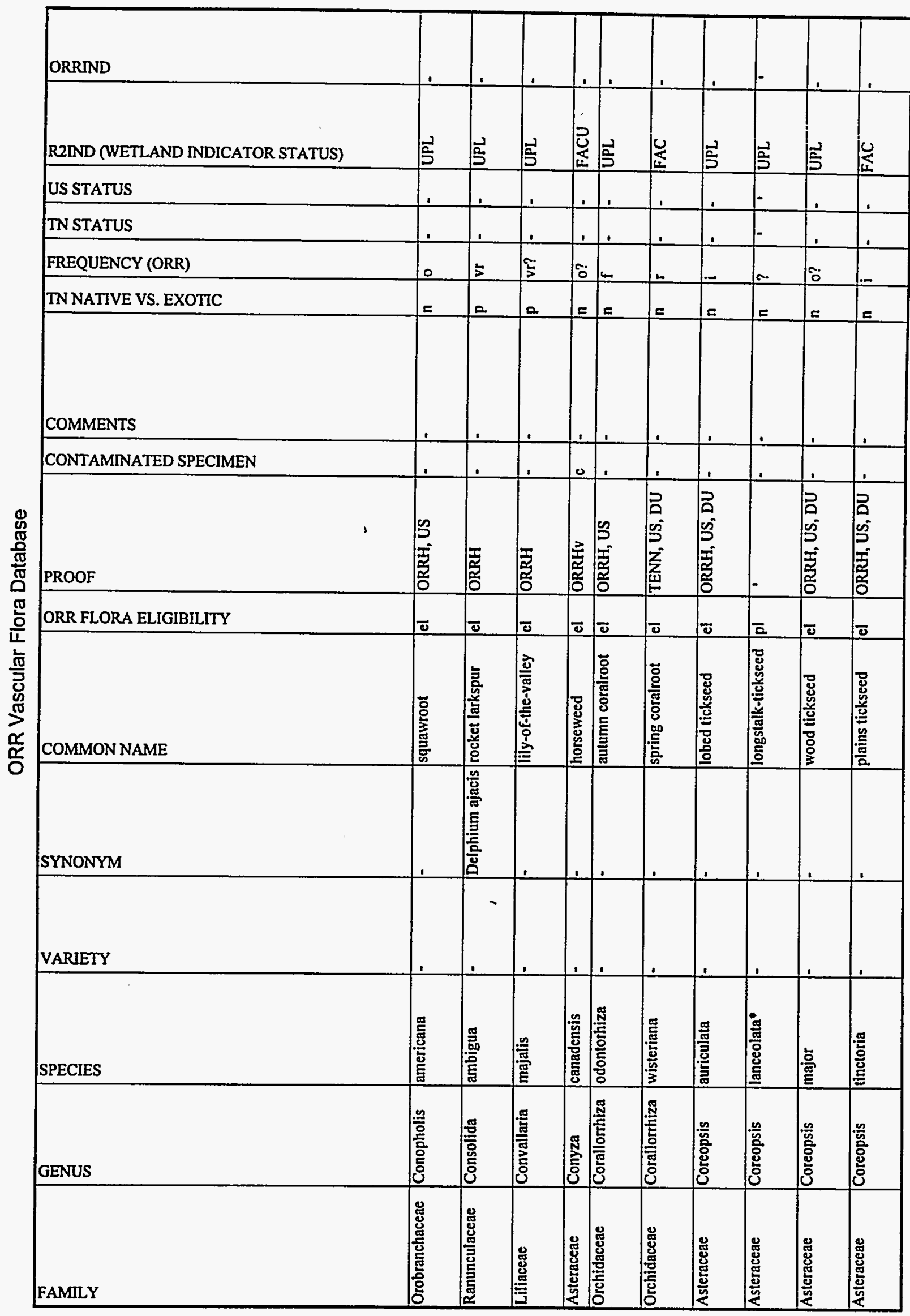




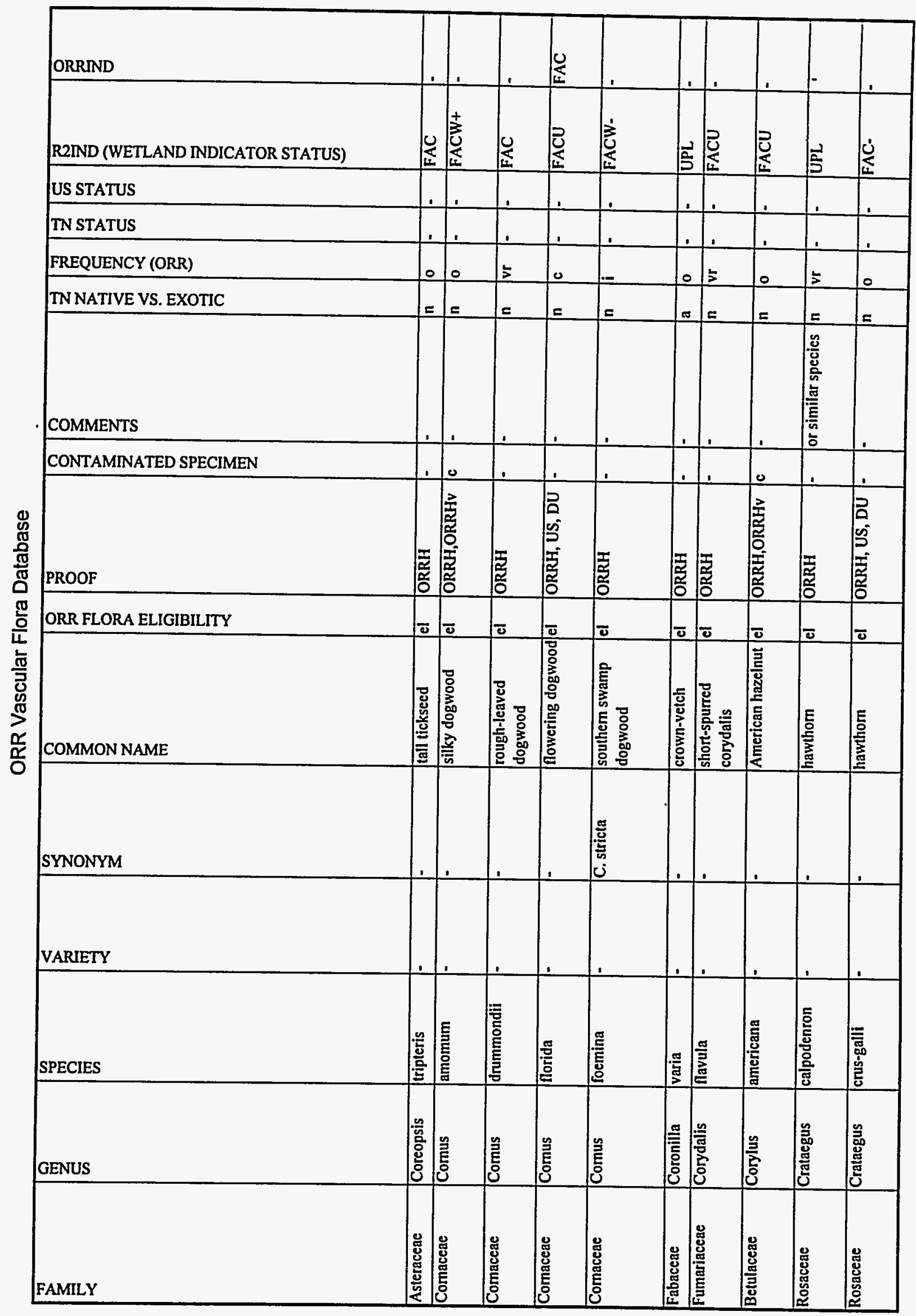




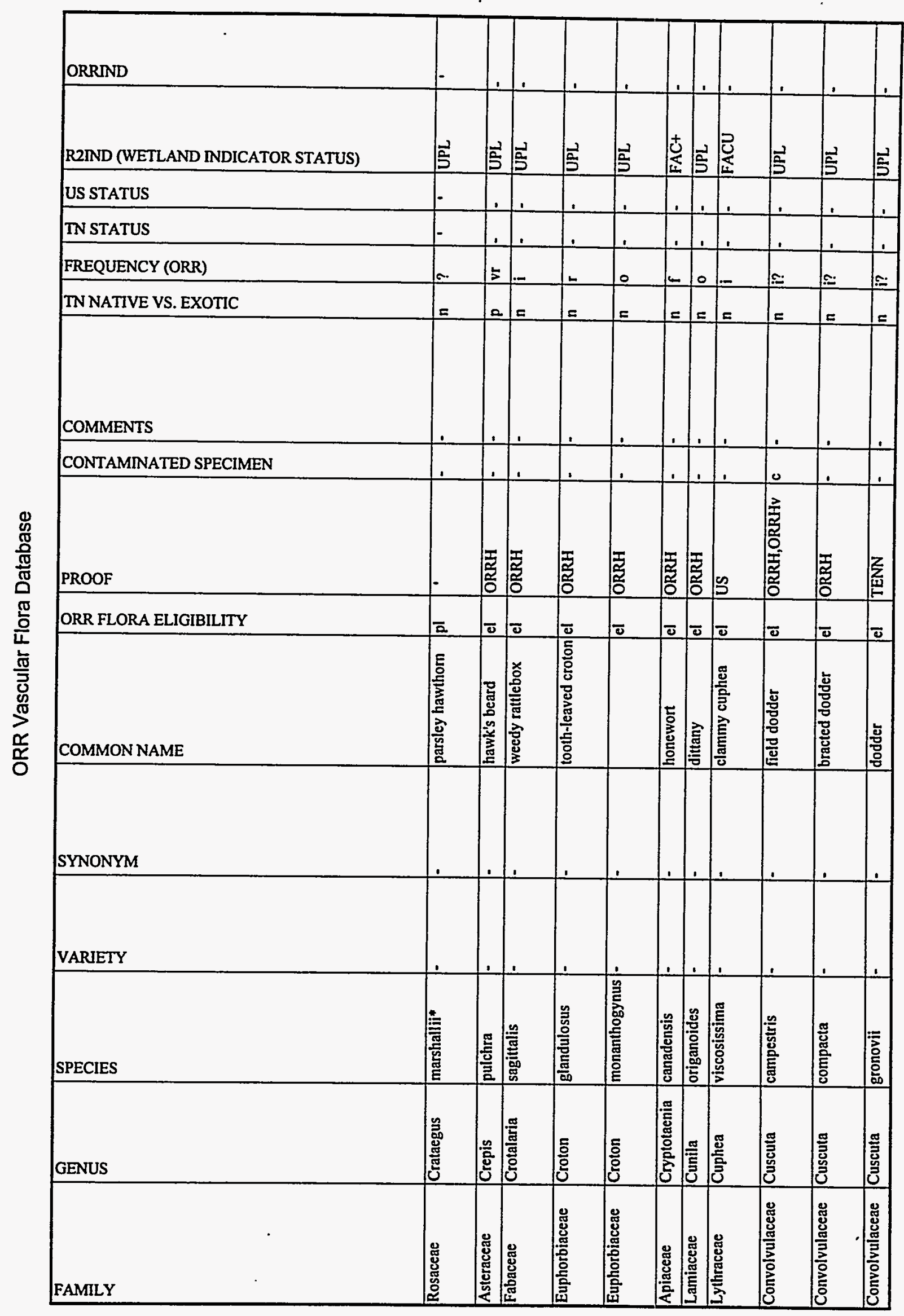




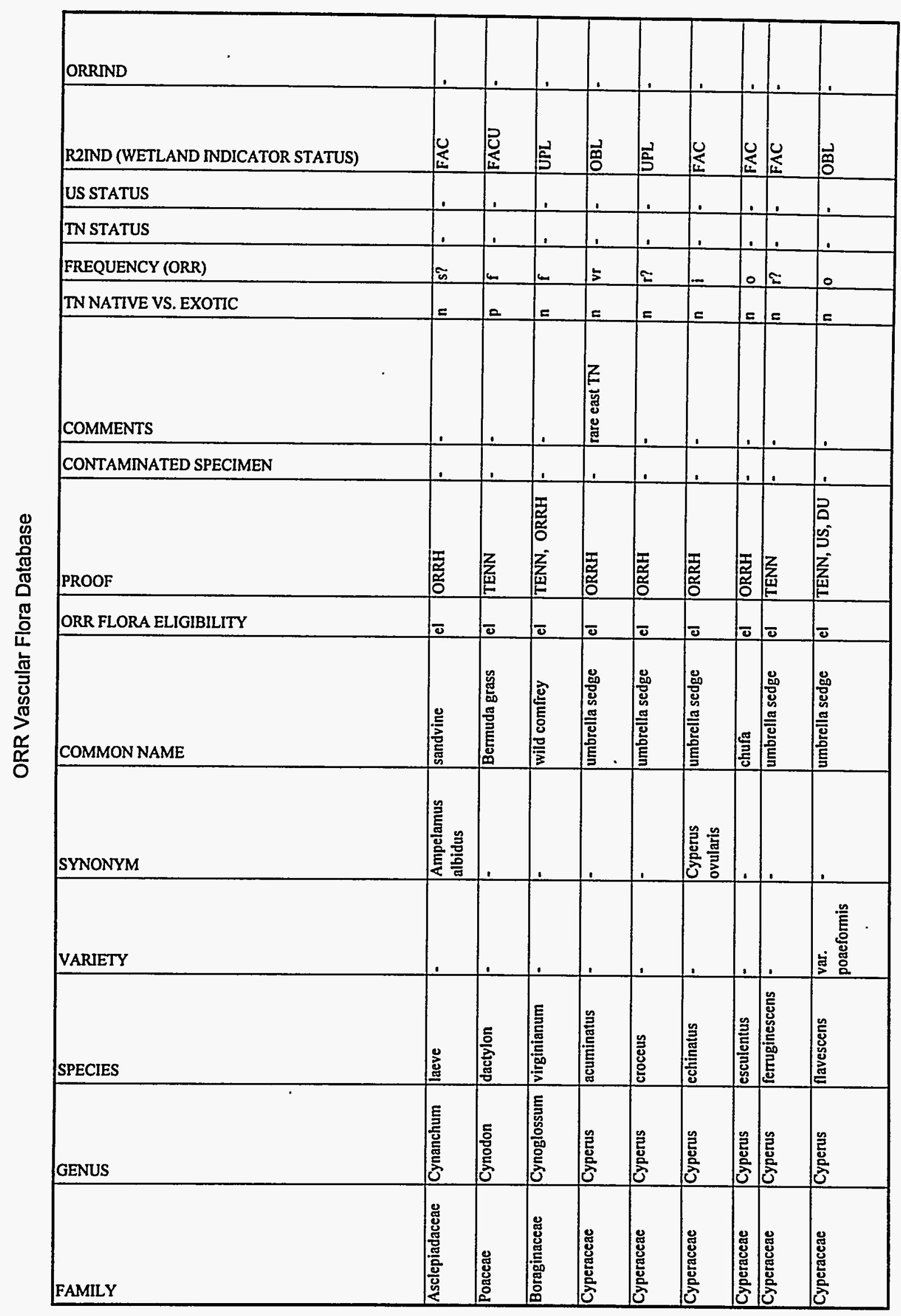




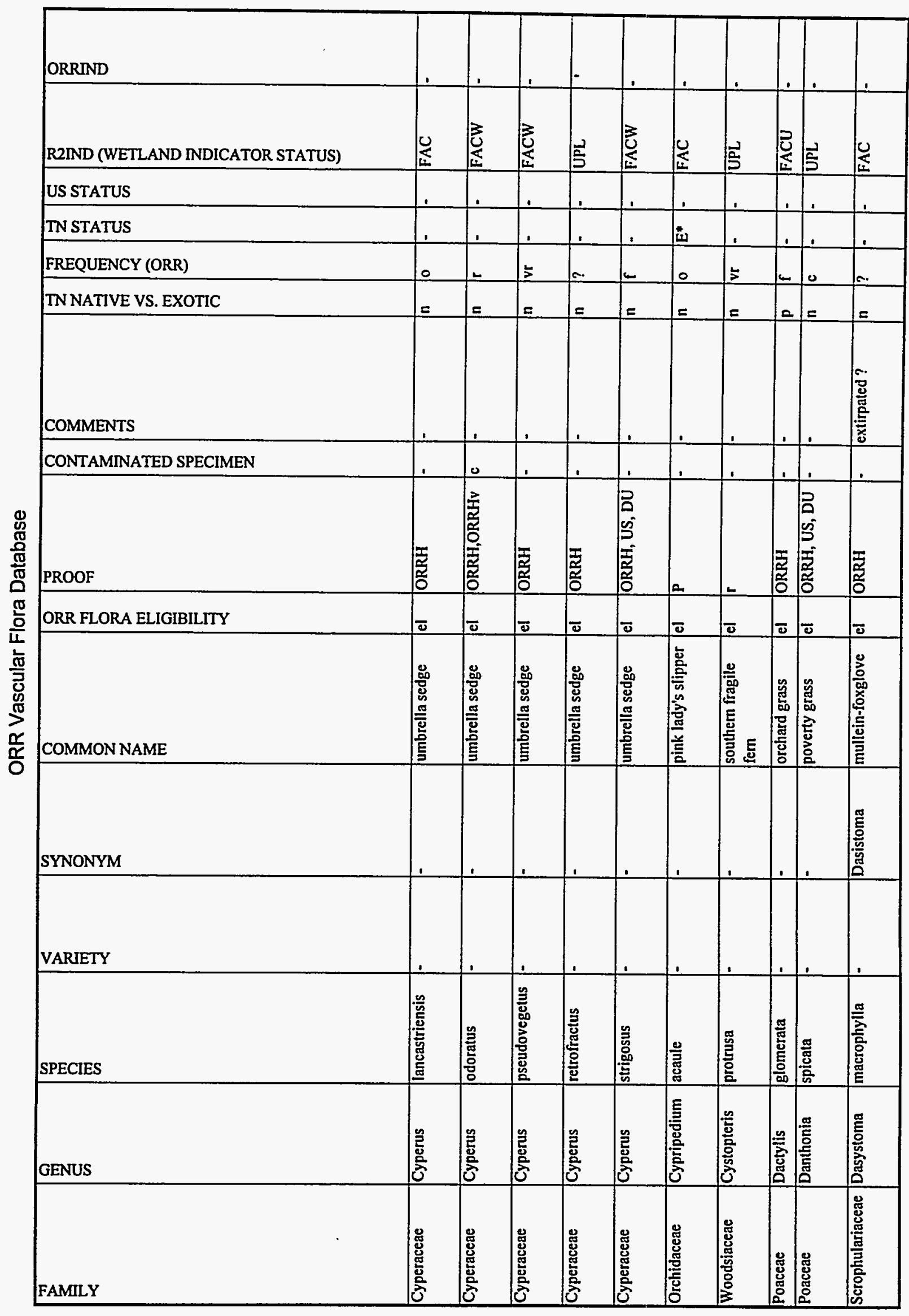




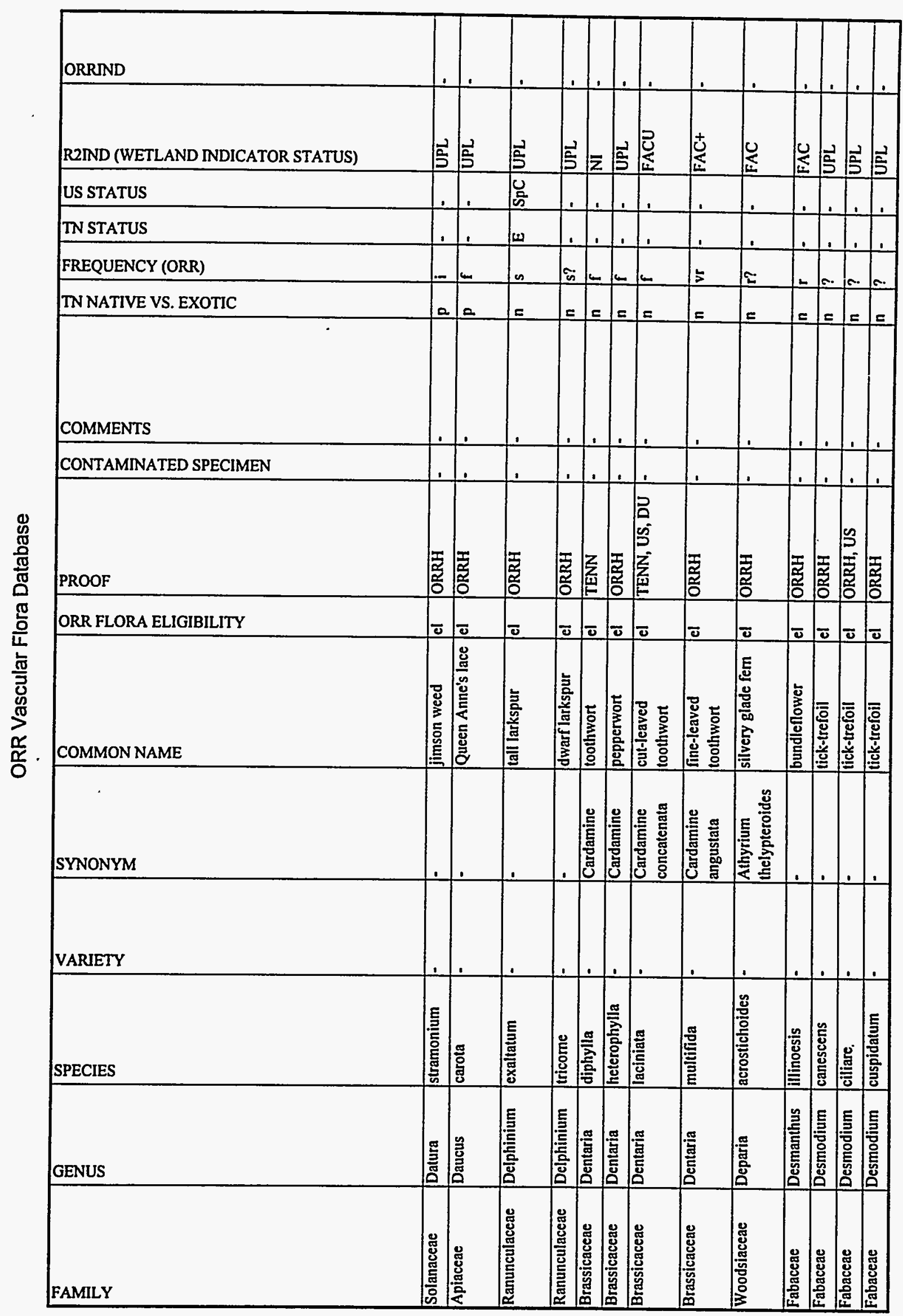




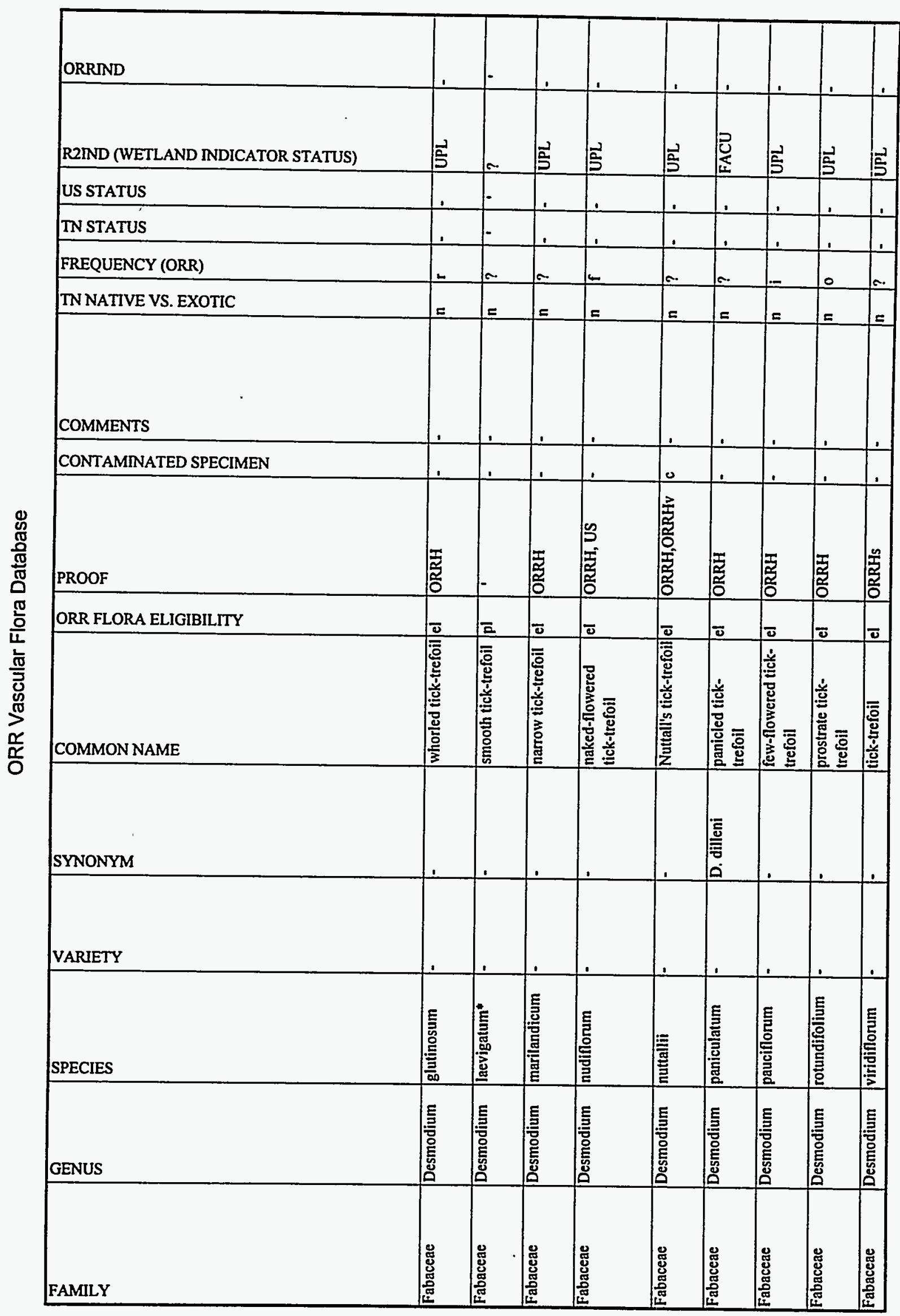




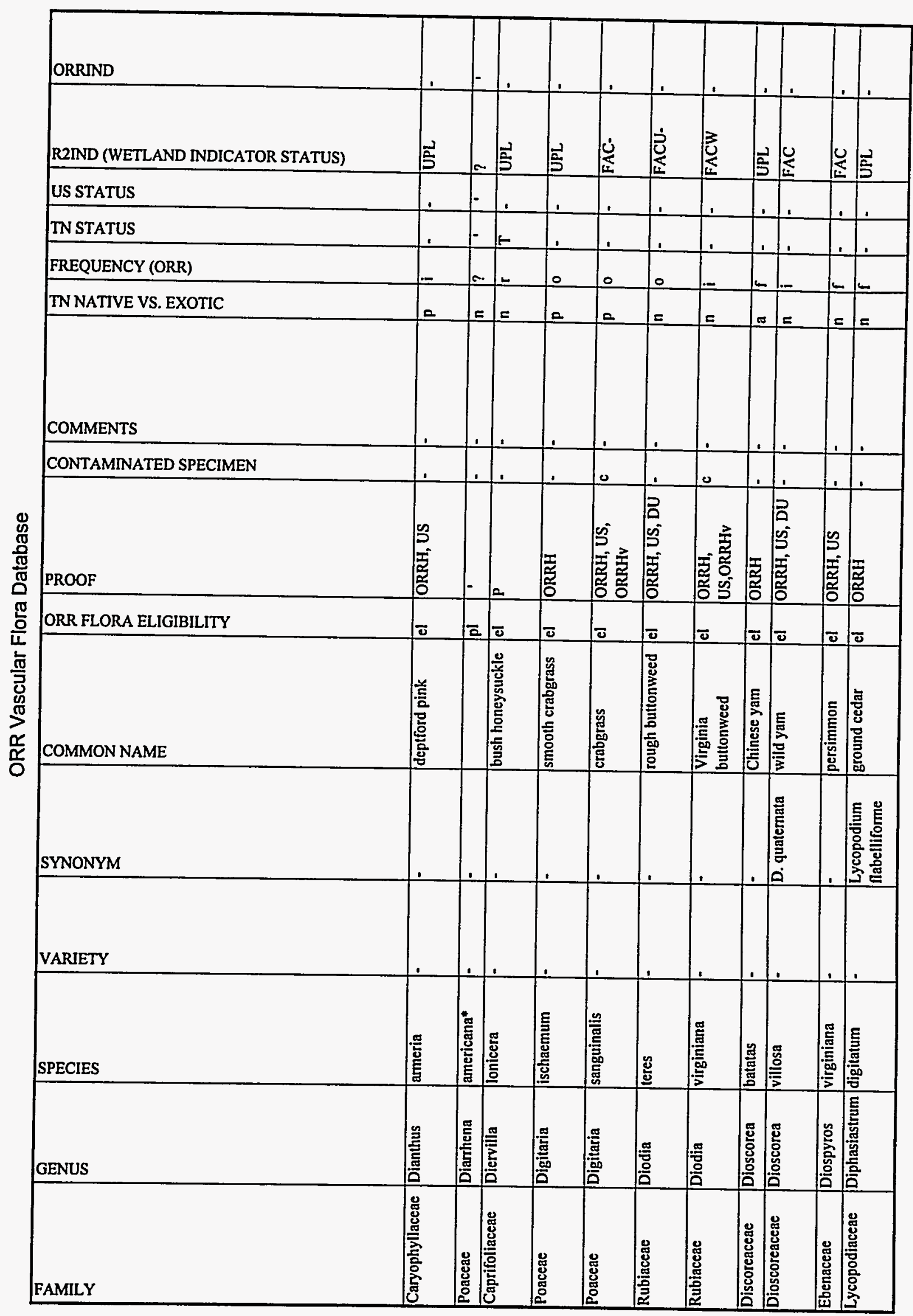




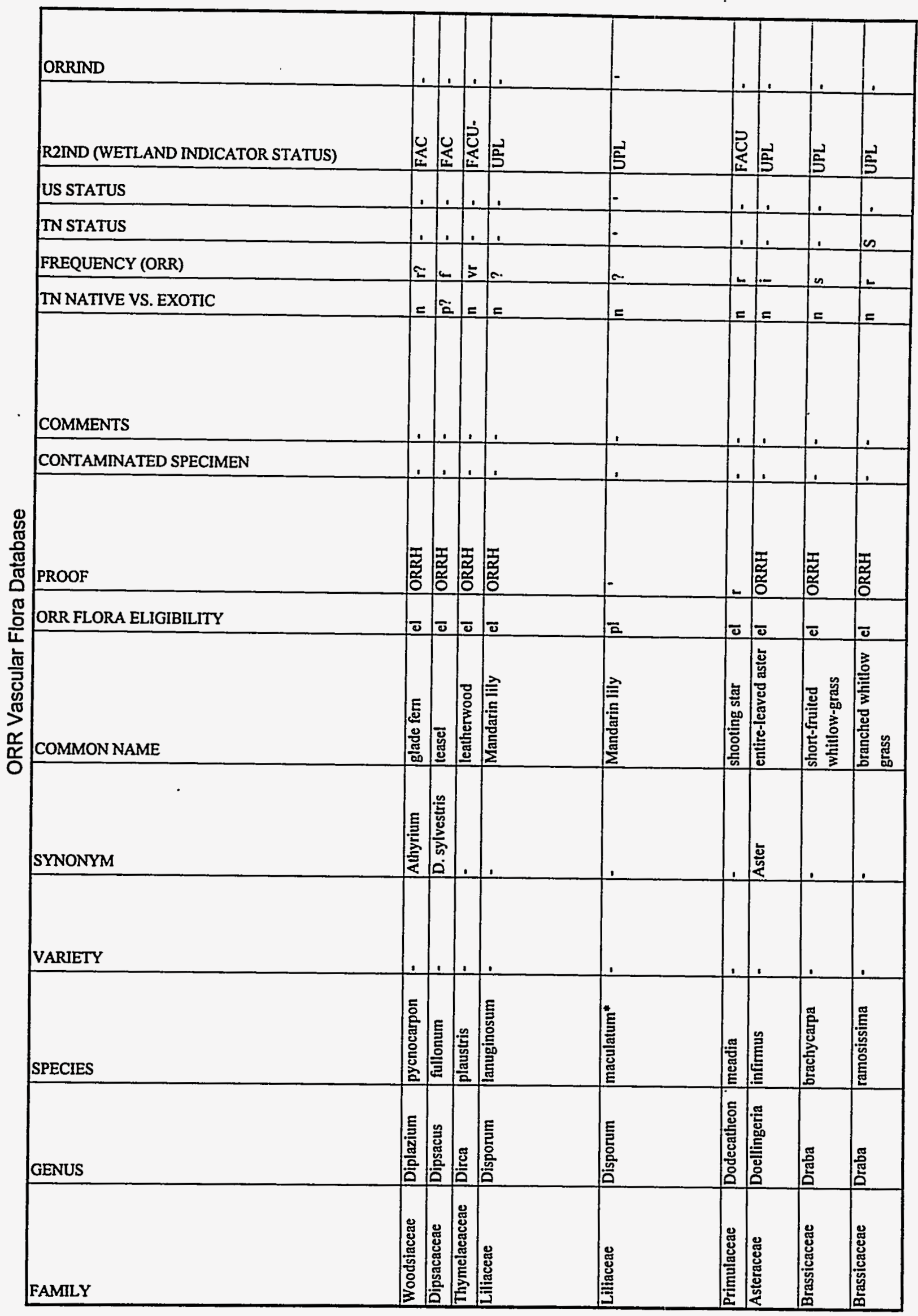




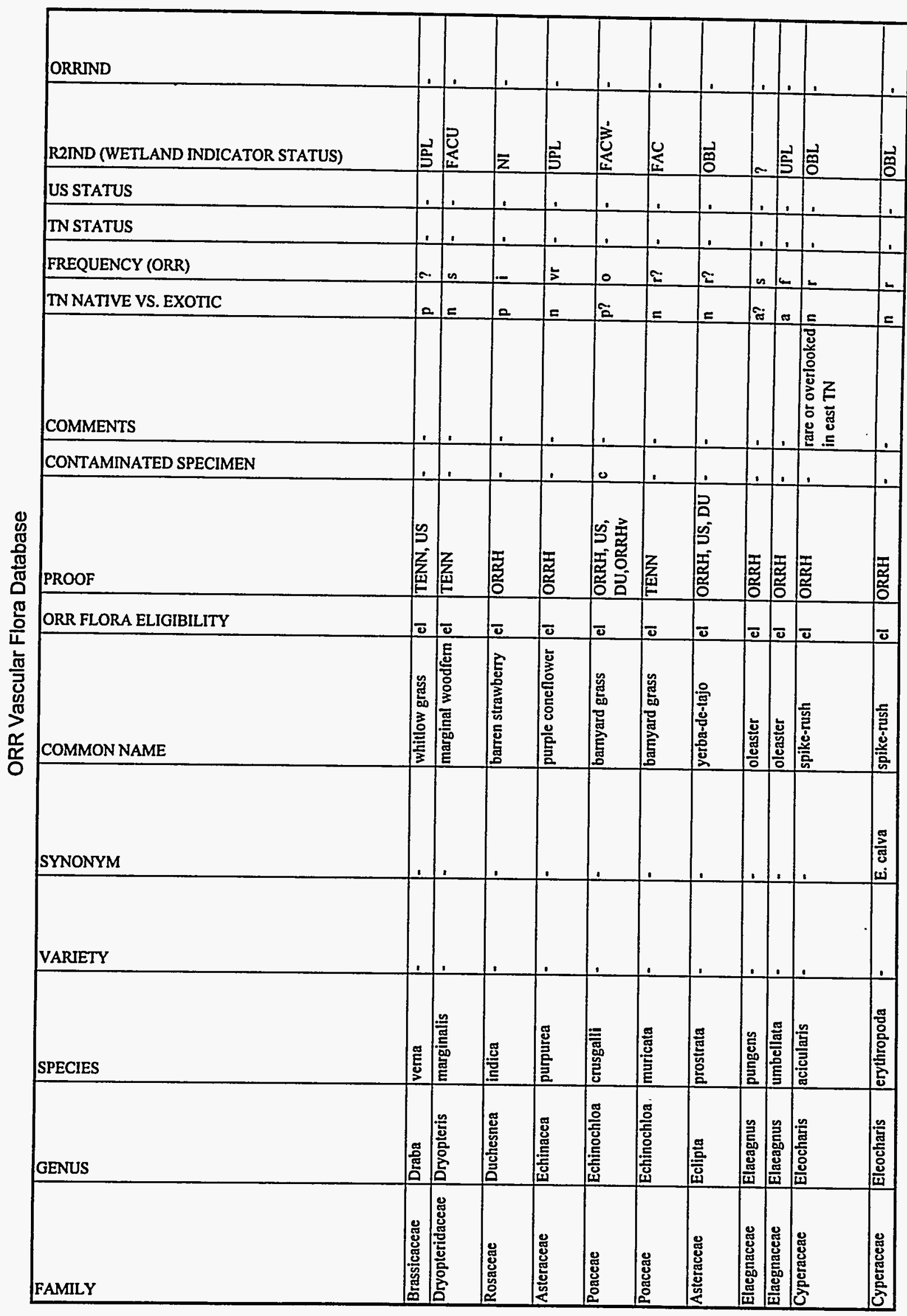




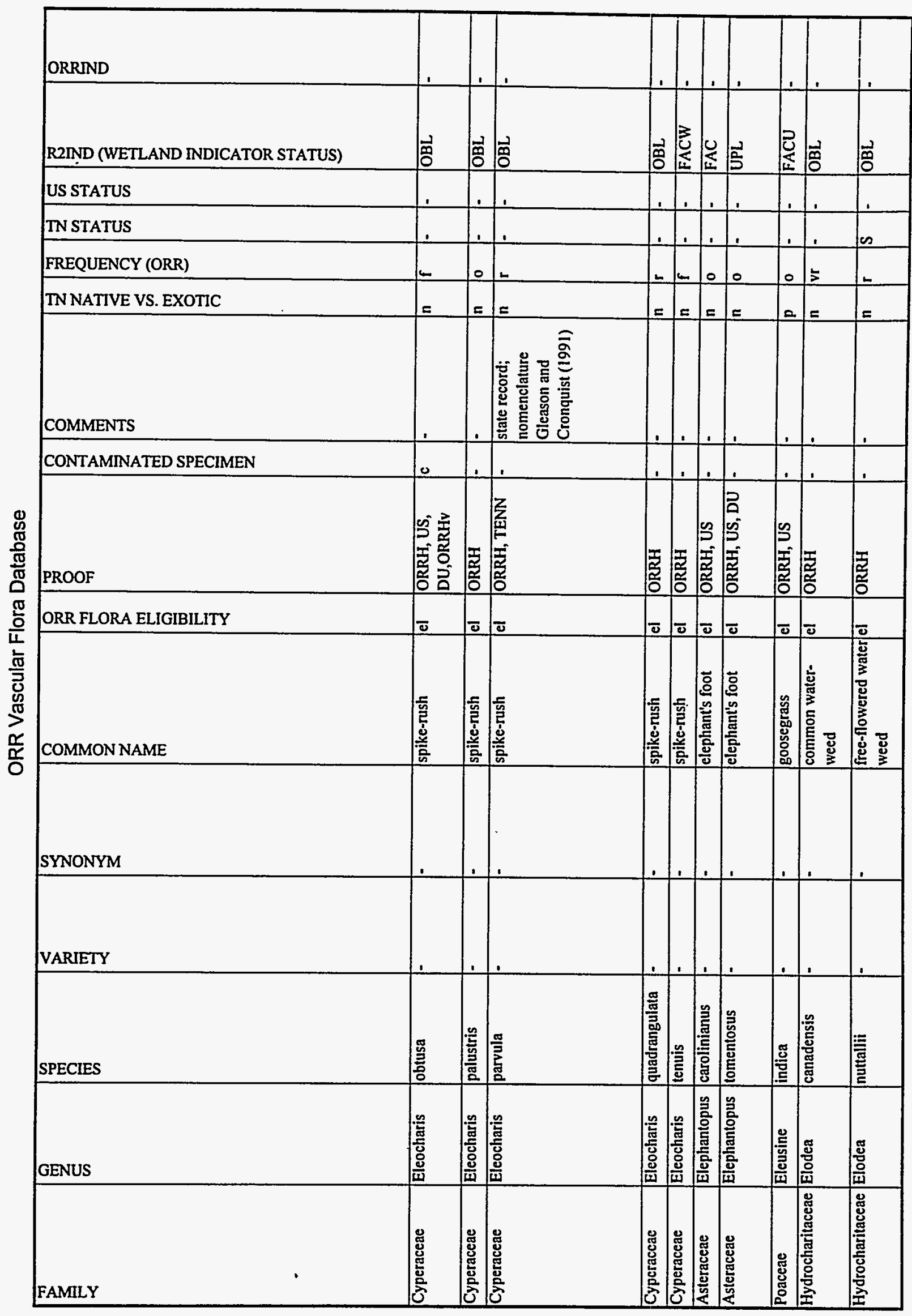




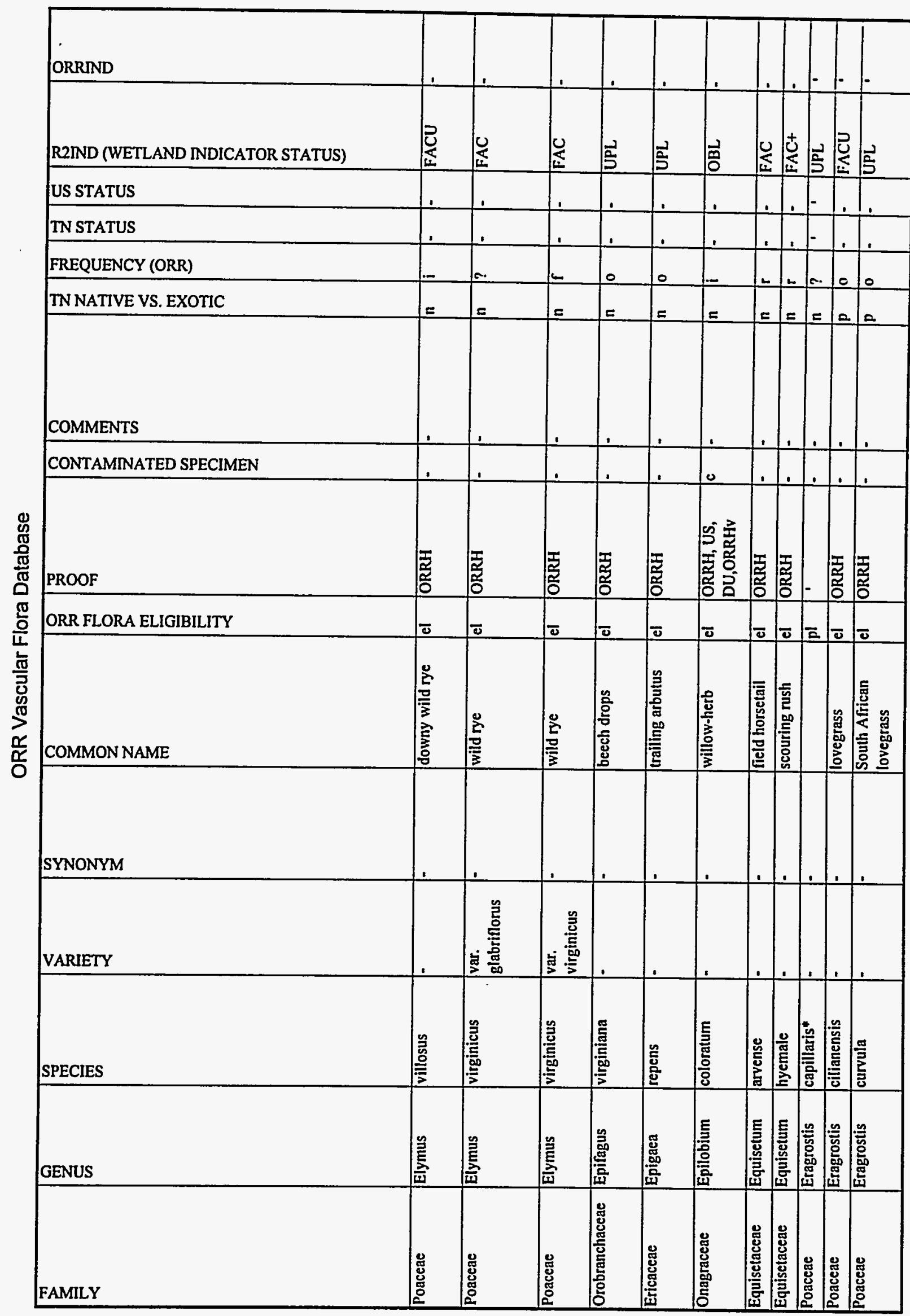




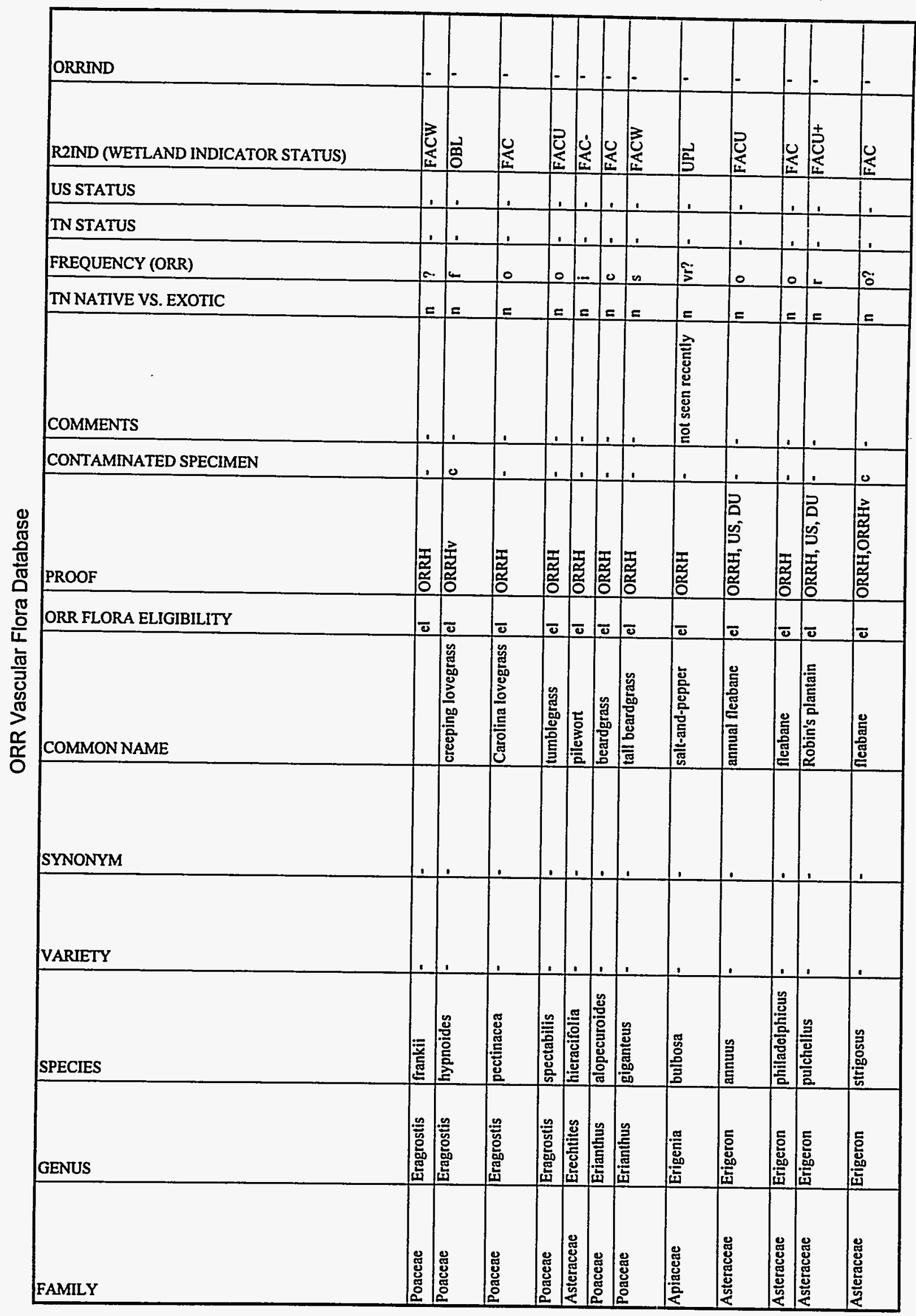




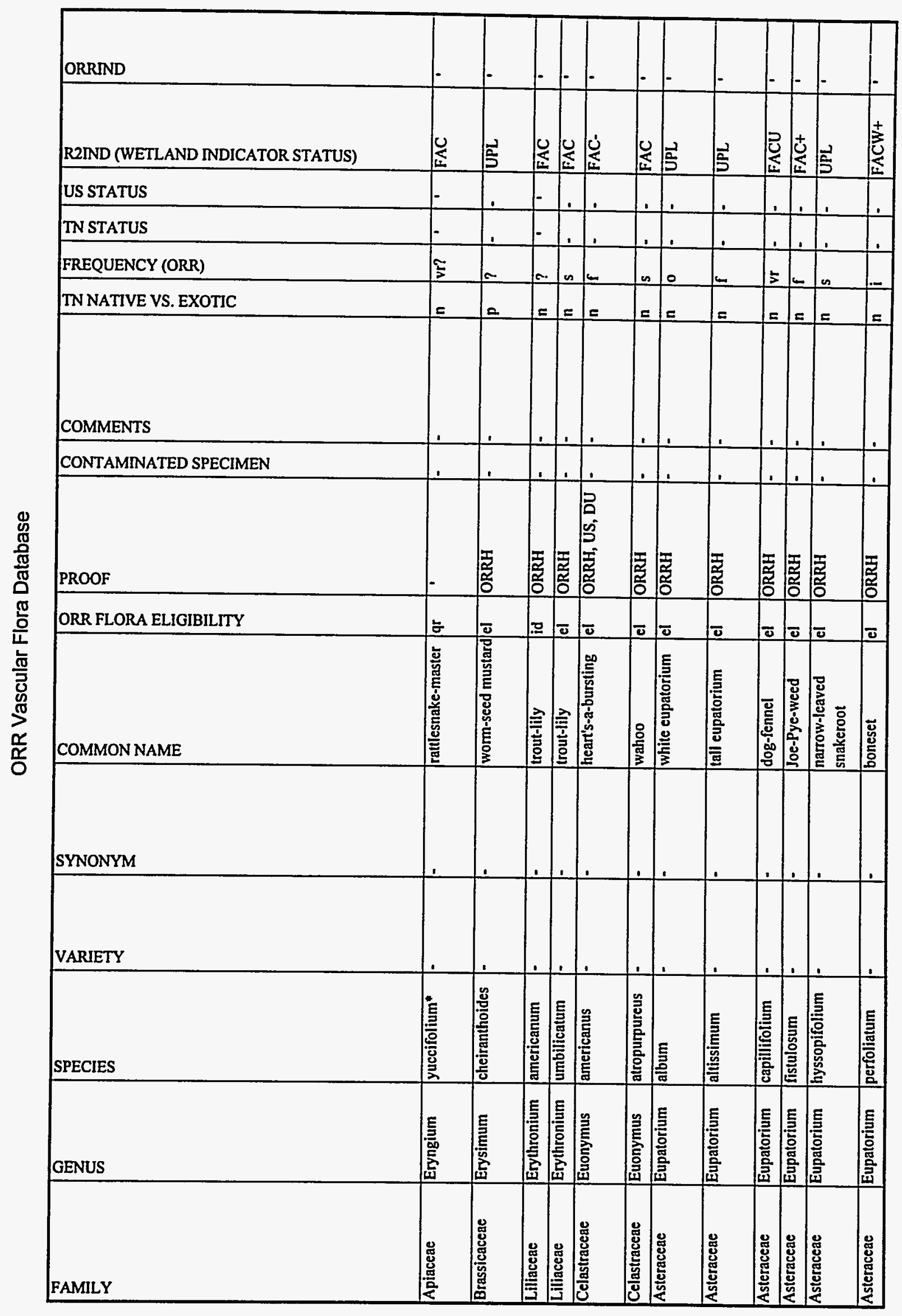




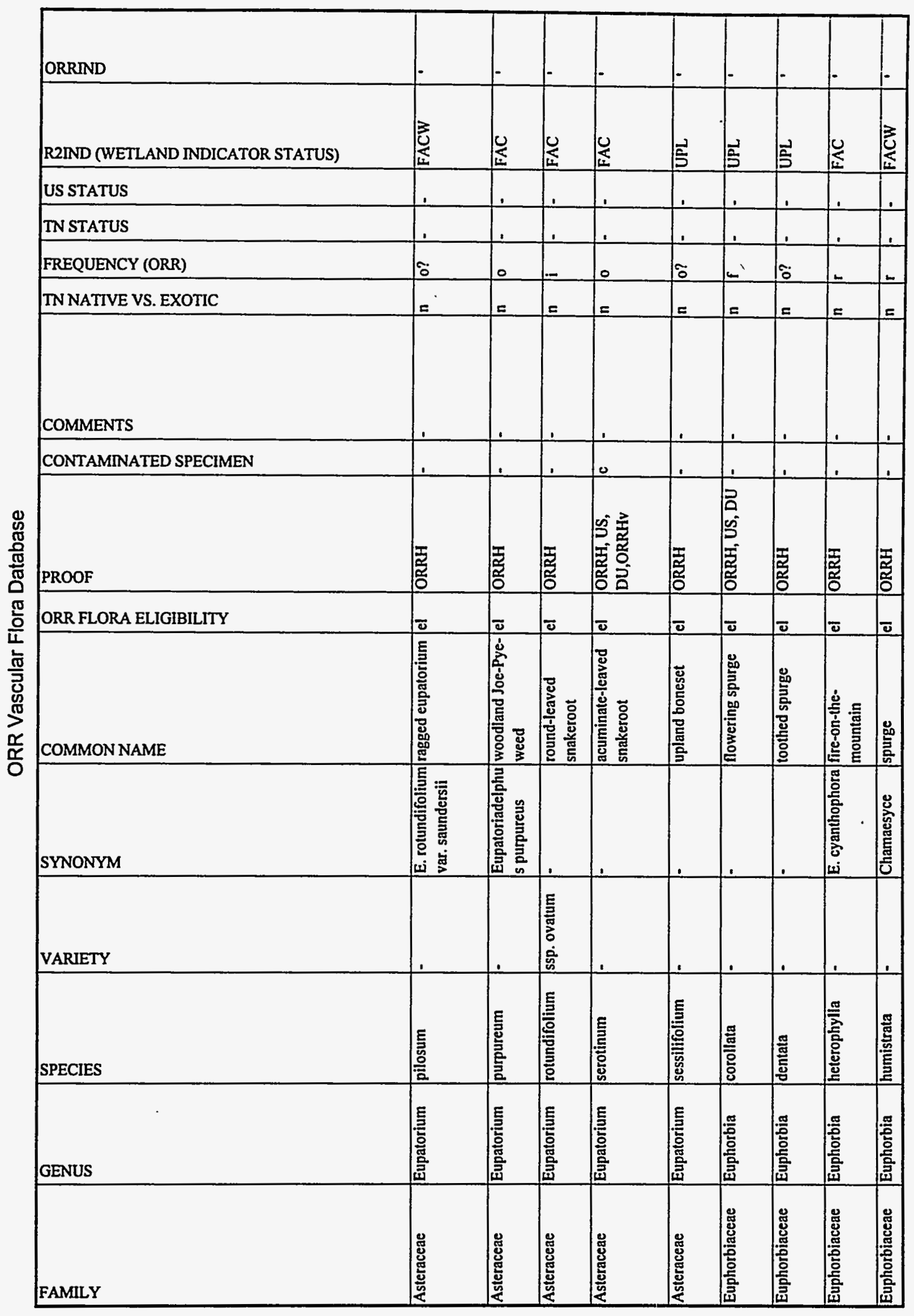




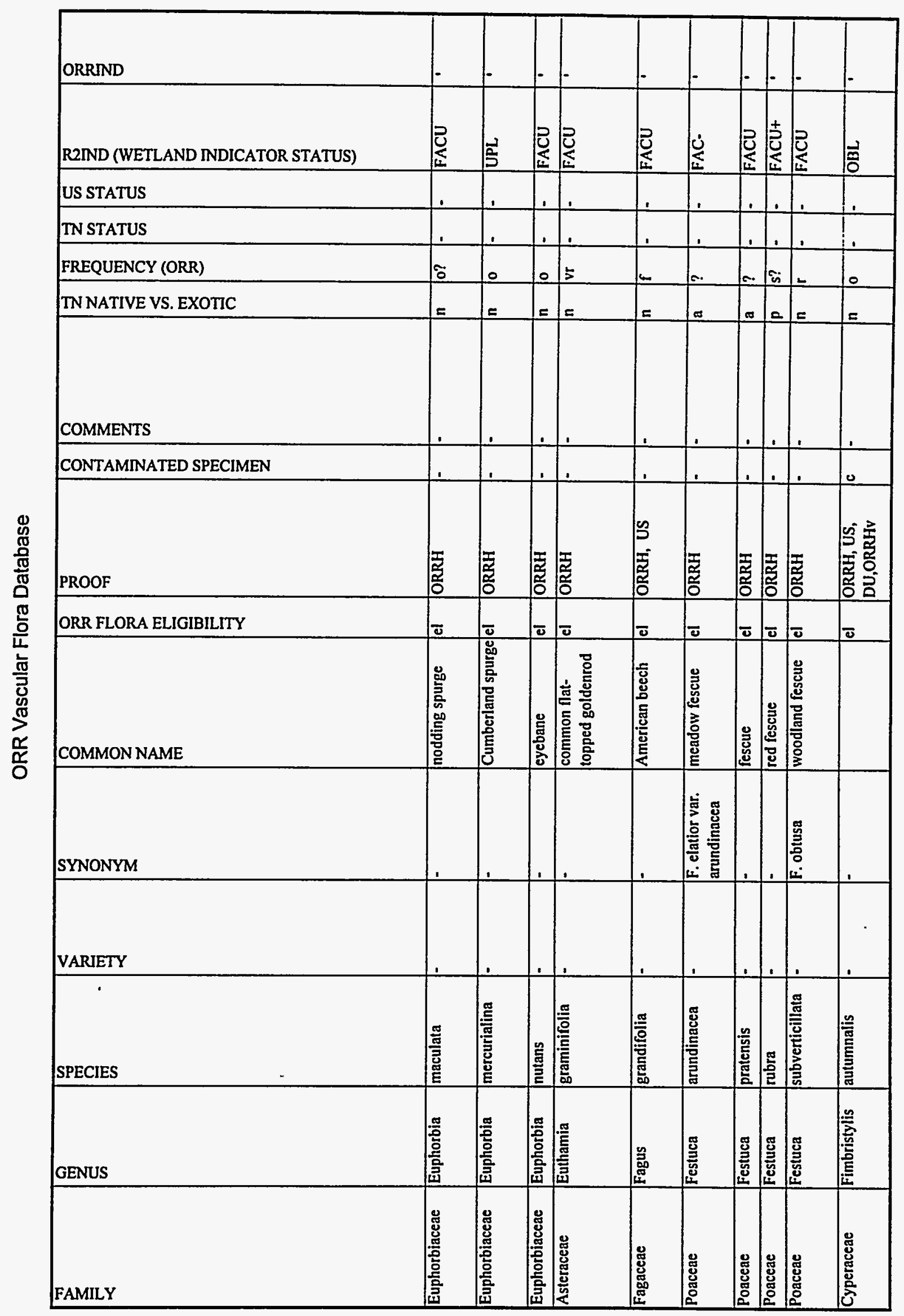




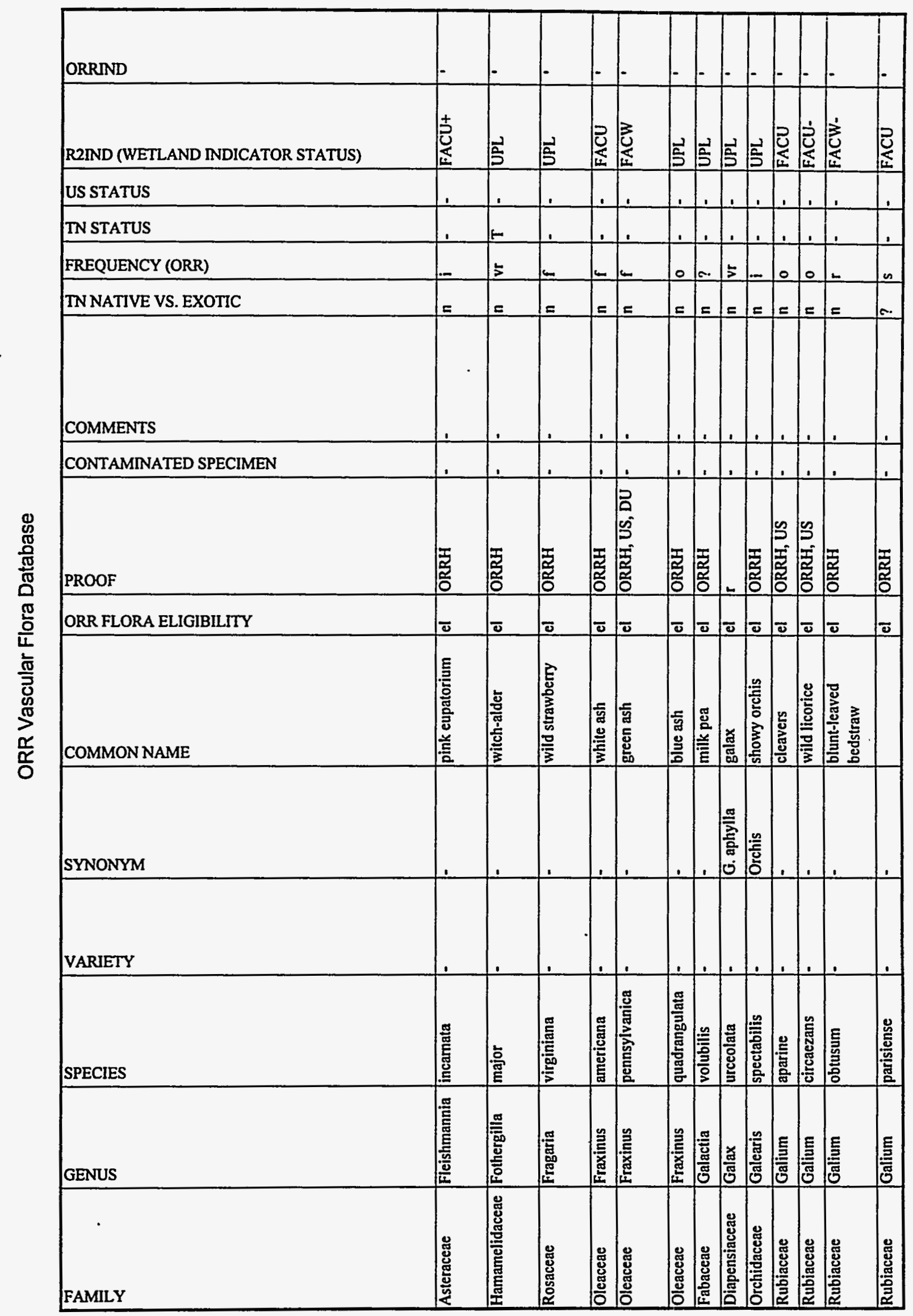




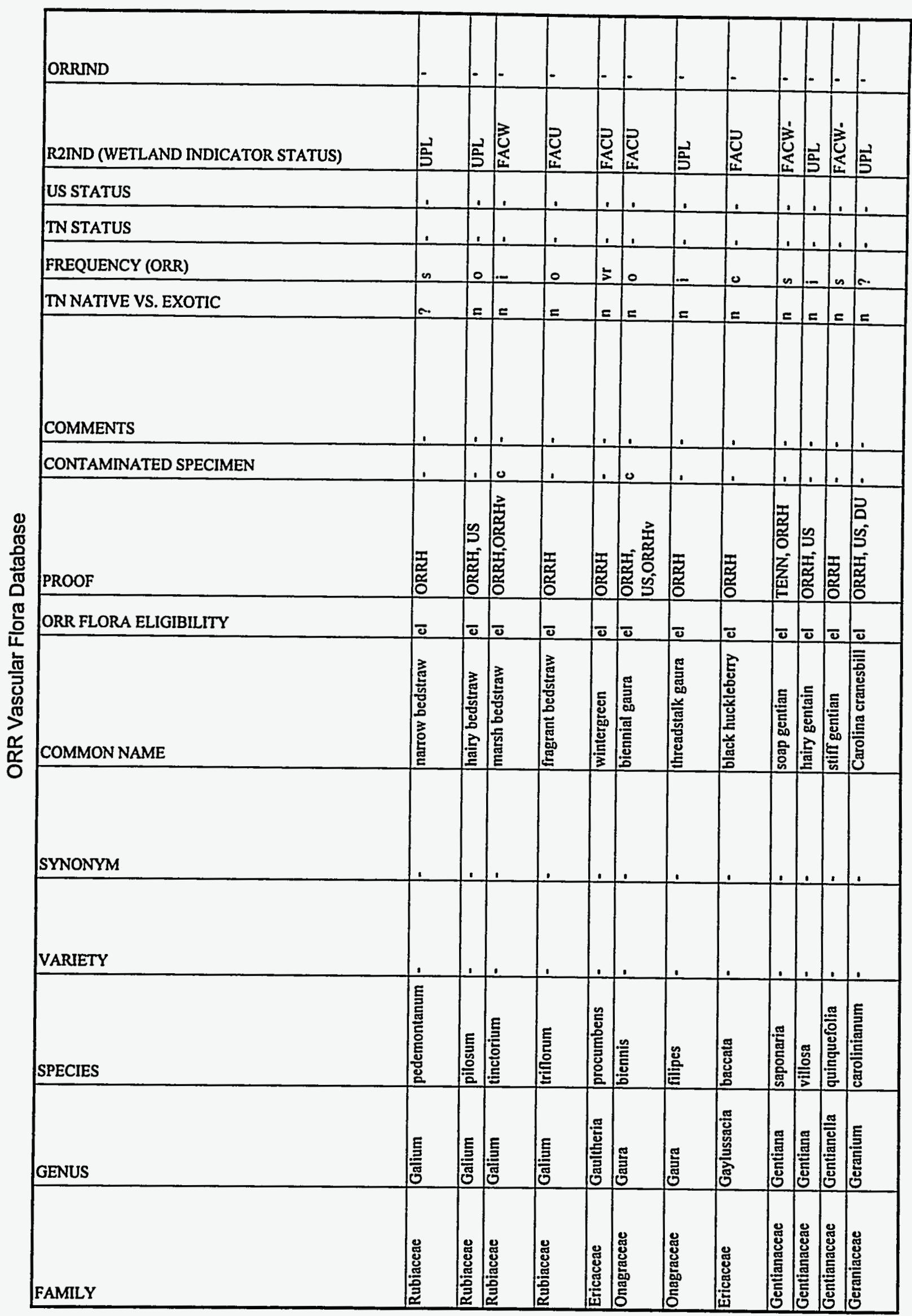




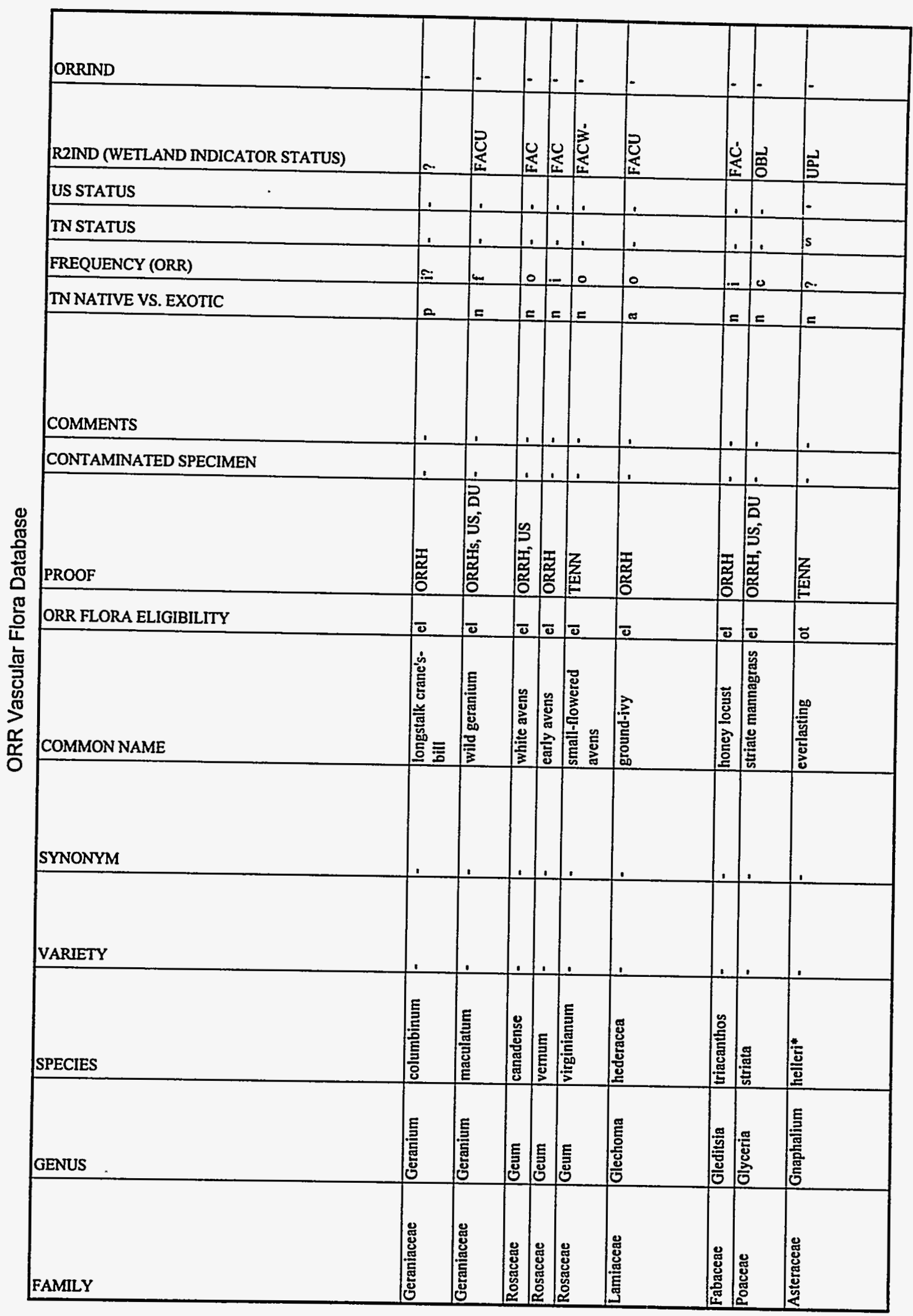




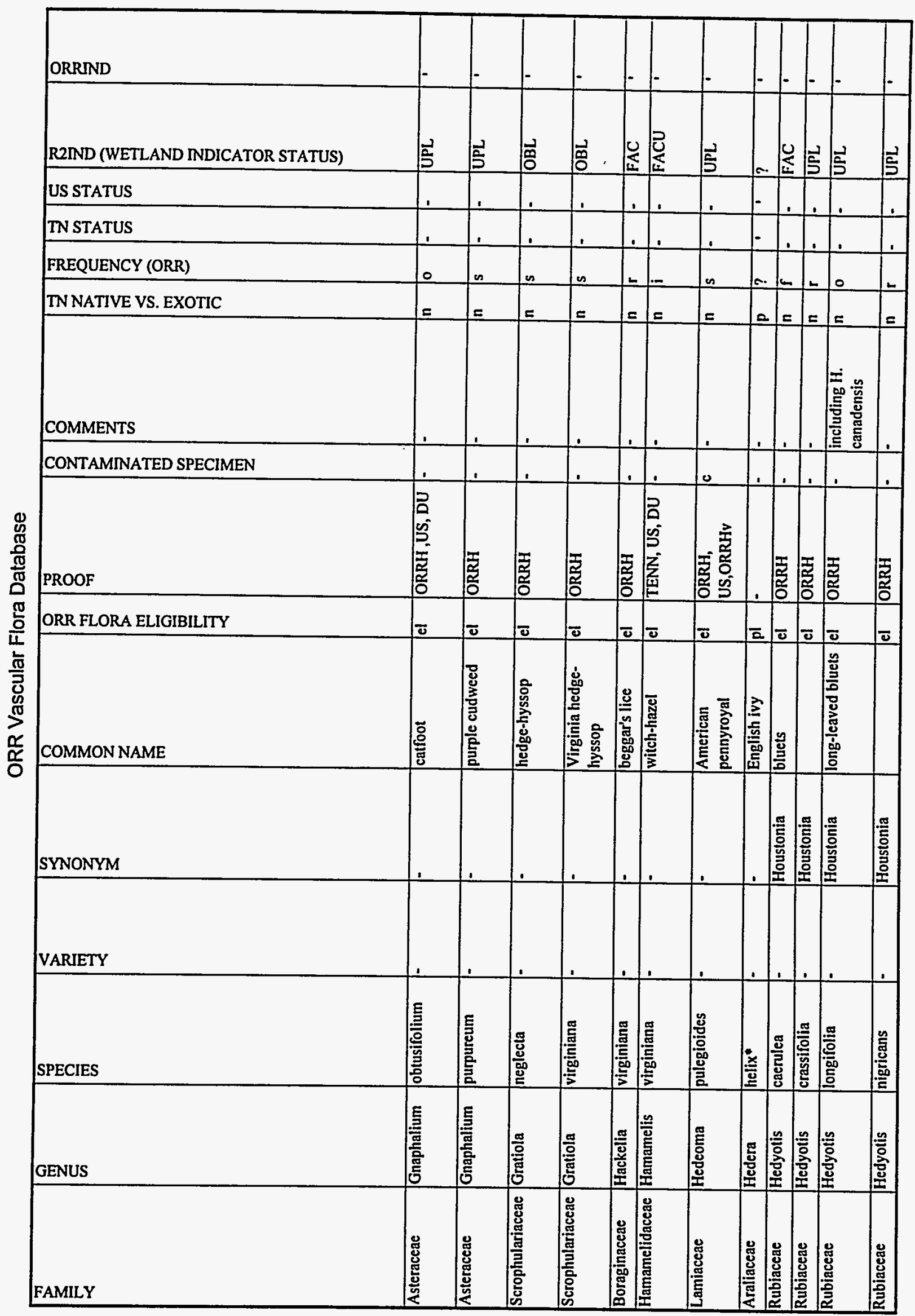




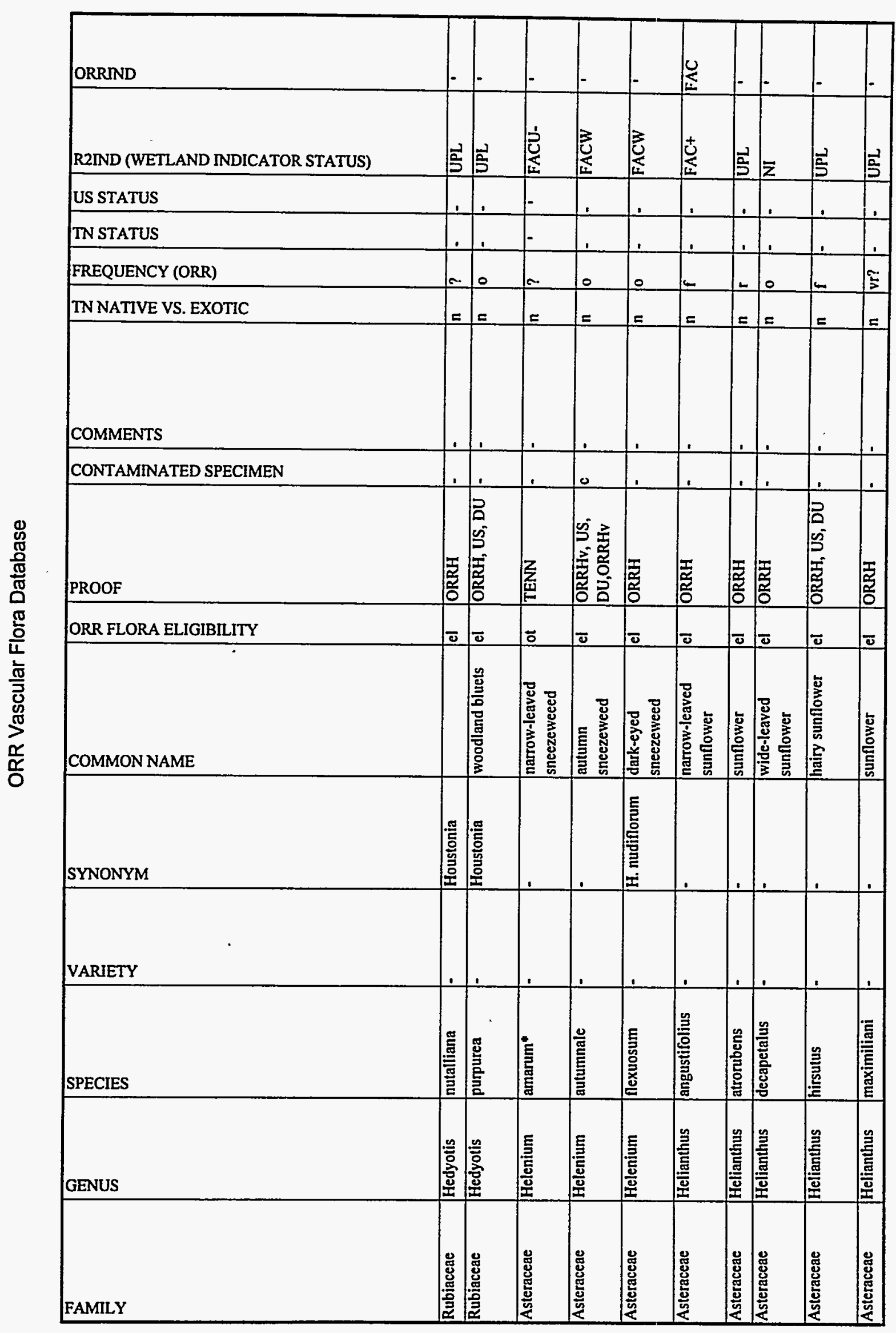


C-61

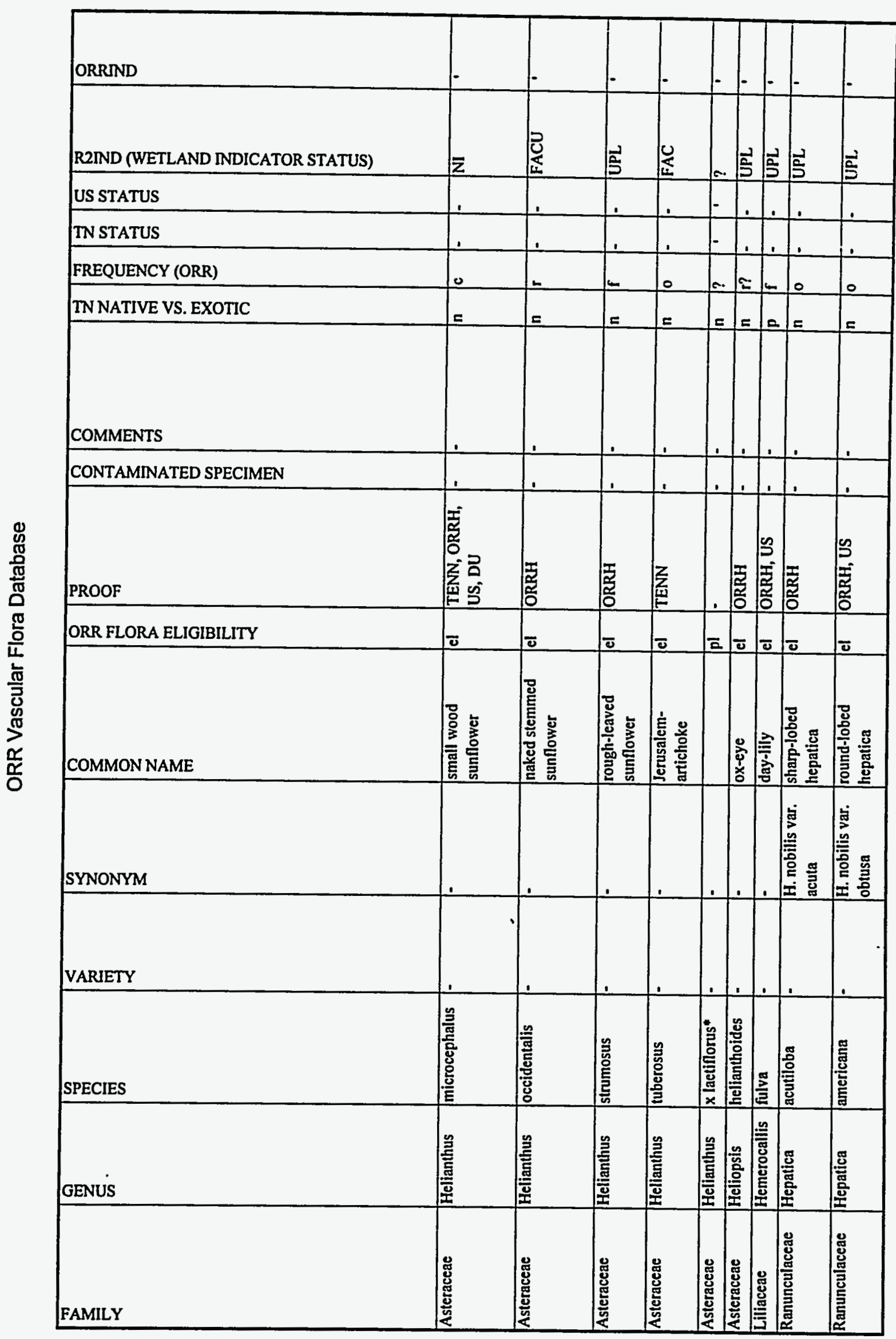




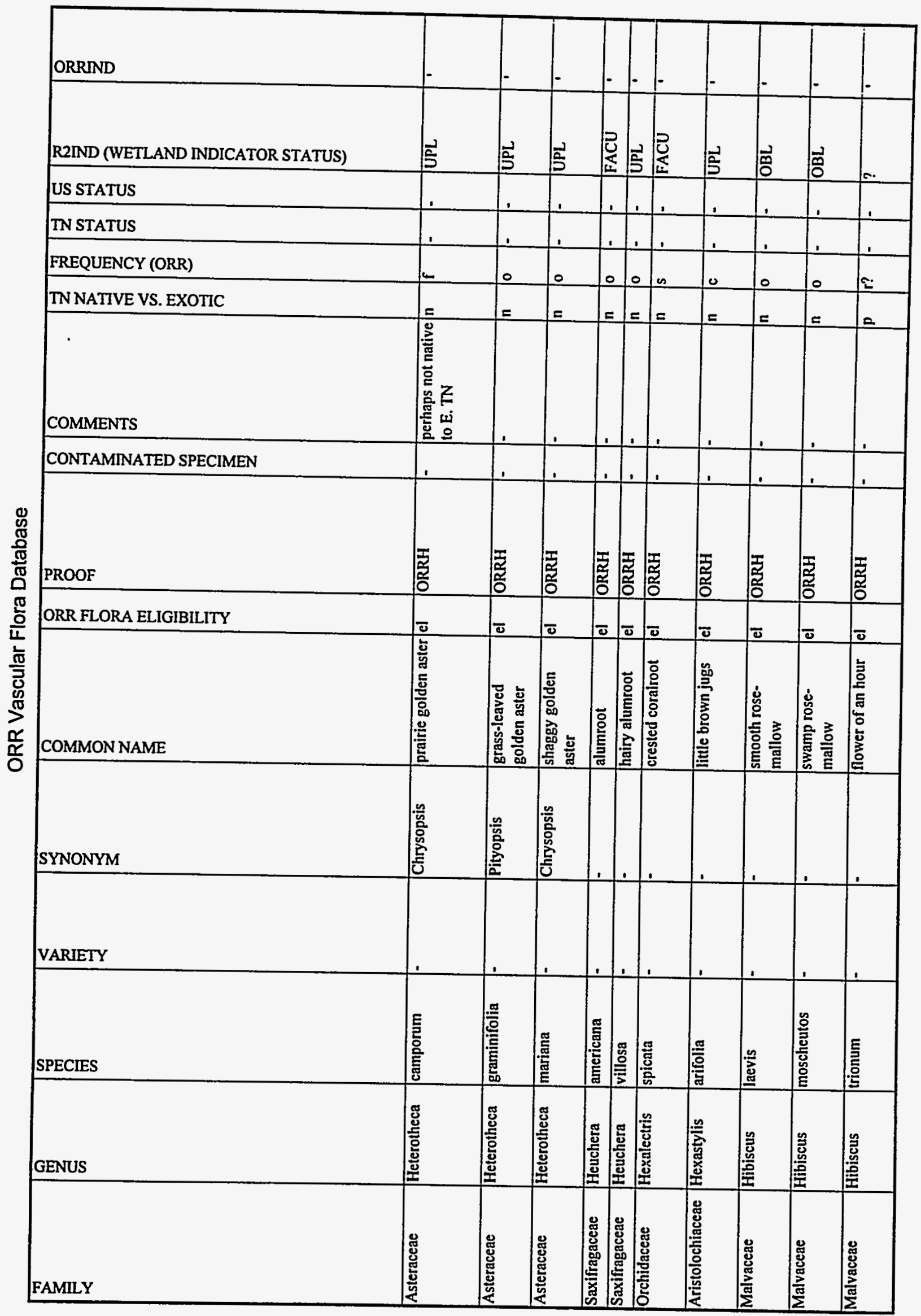




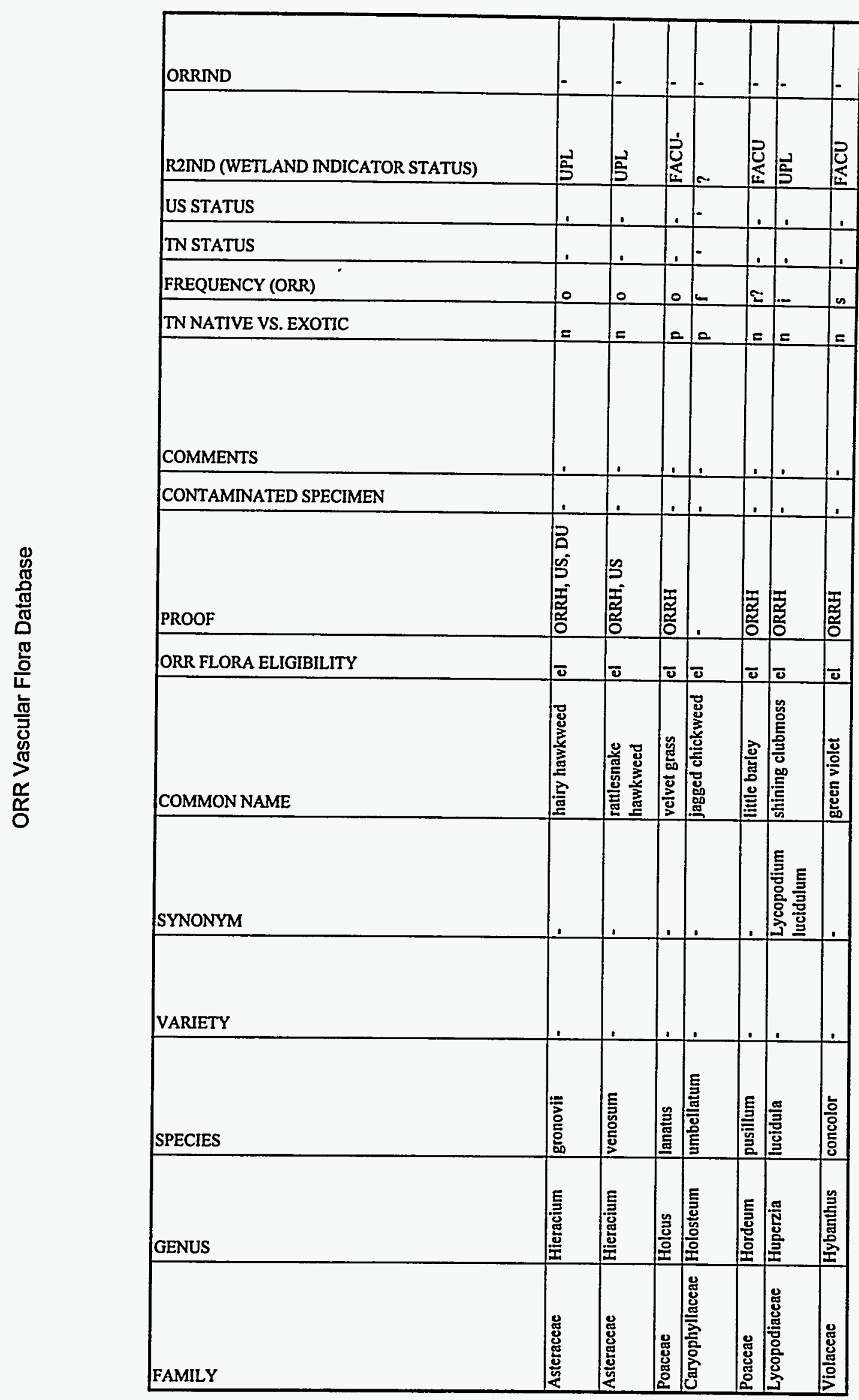




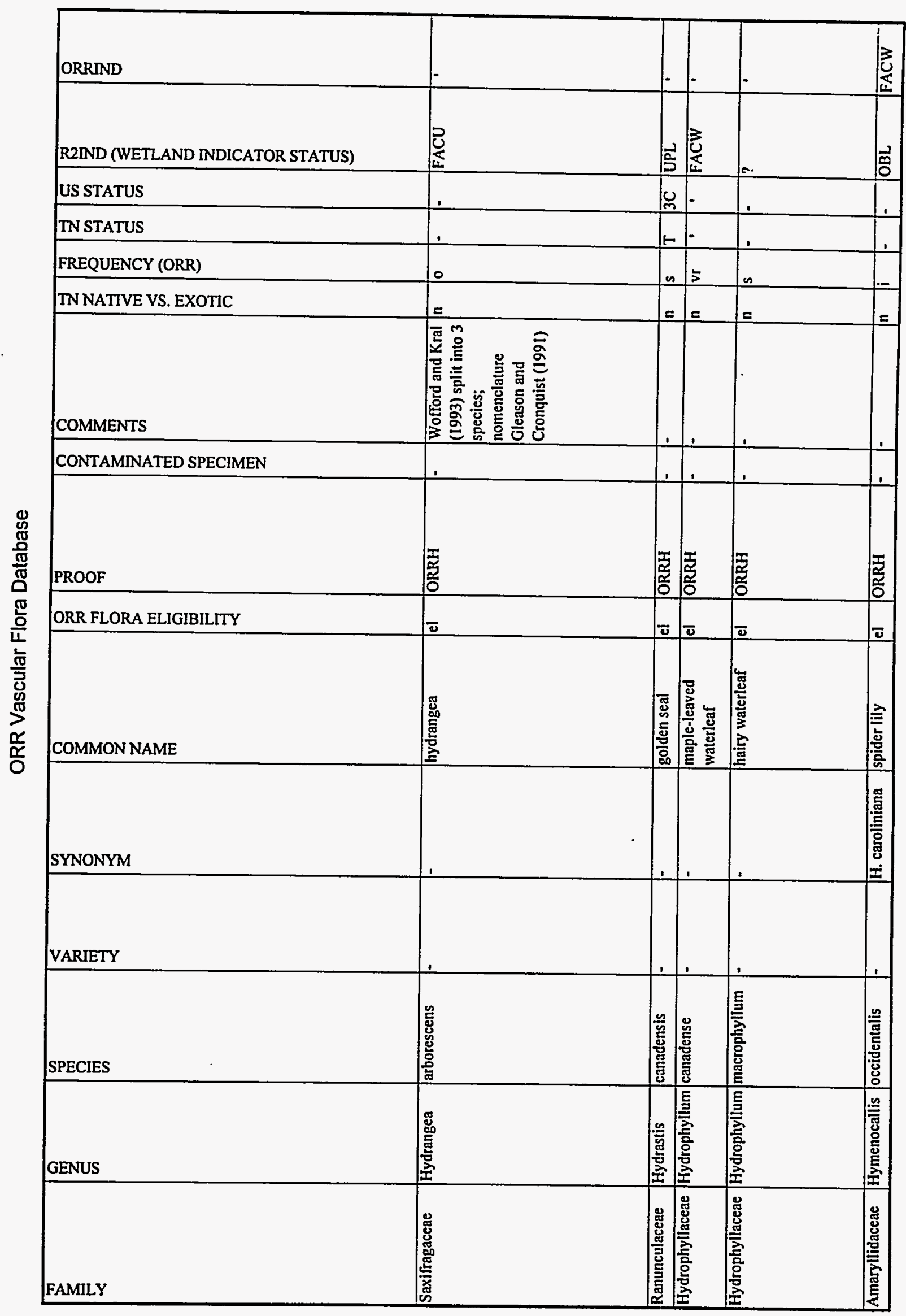




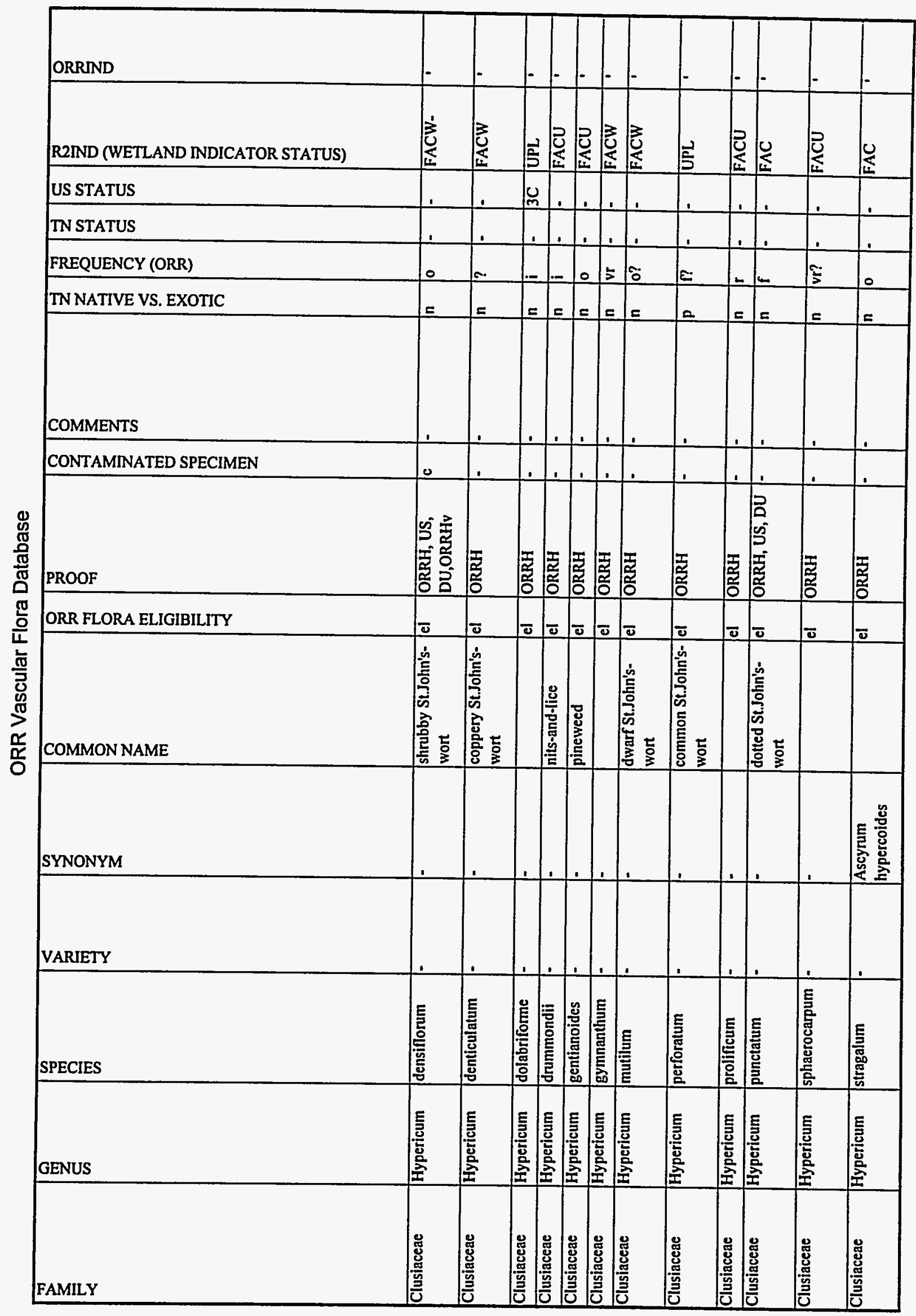


ORR Vascular Flora Database

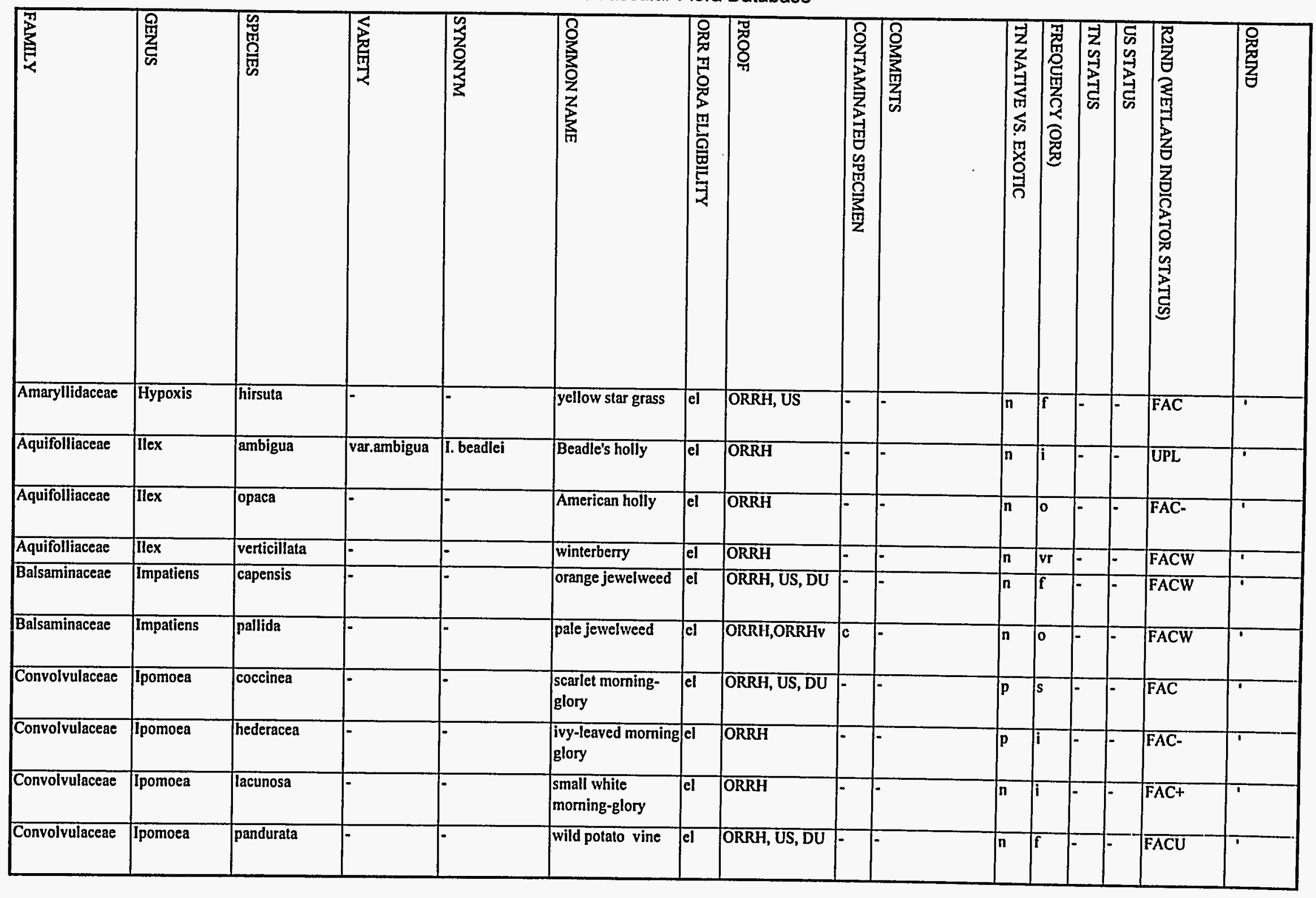




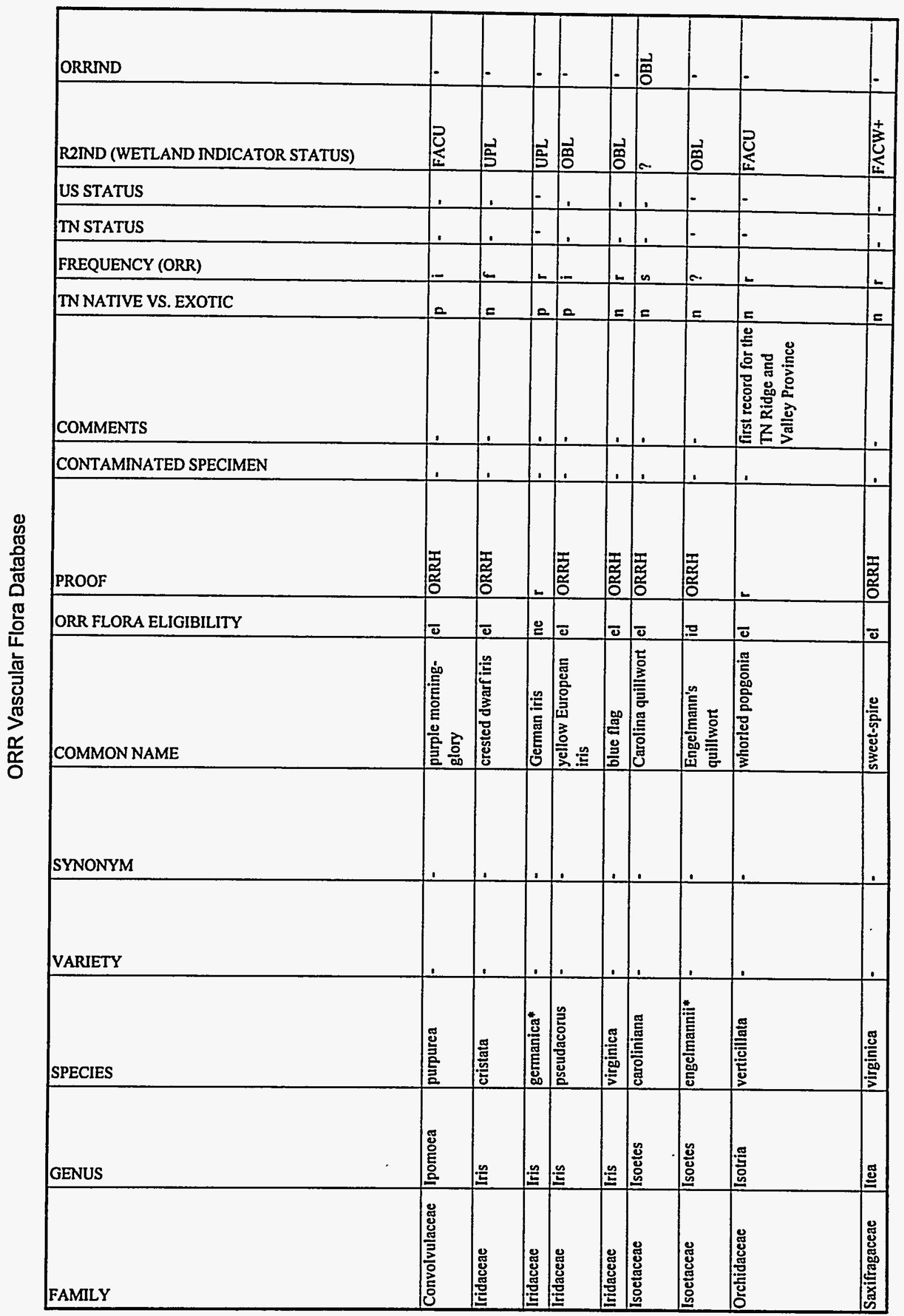




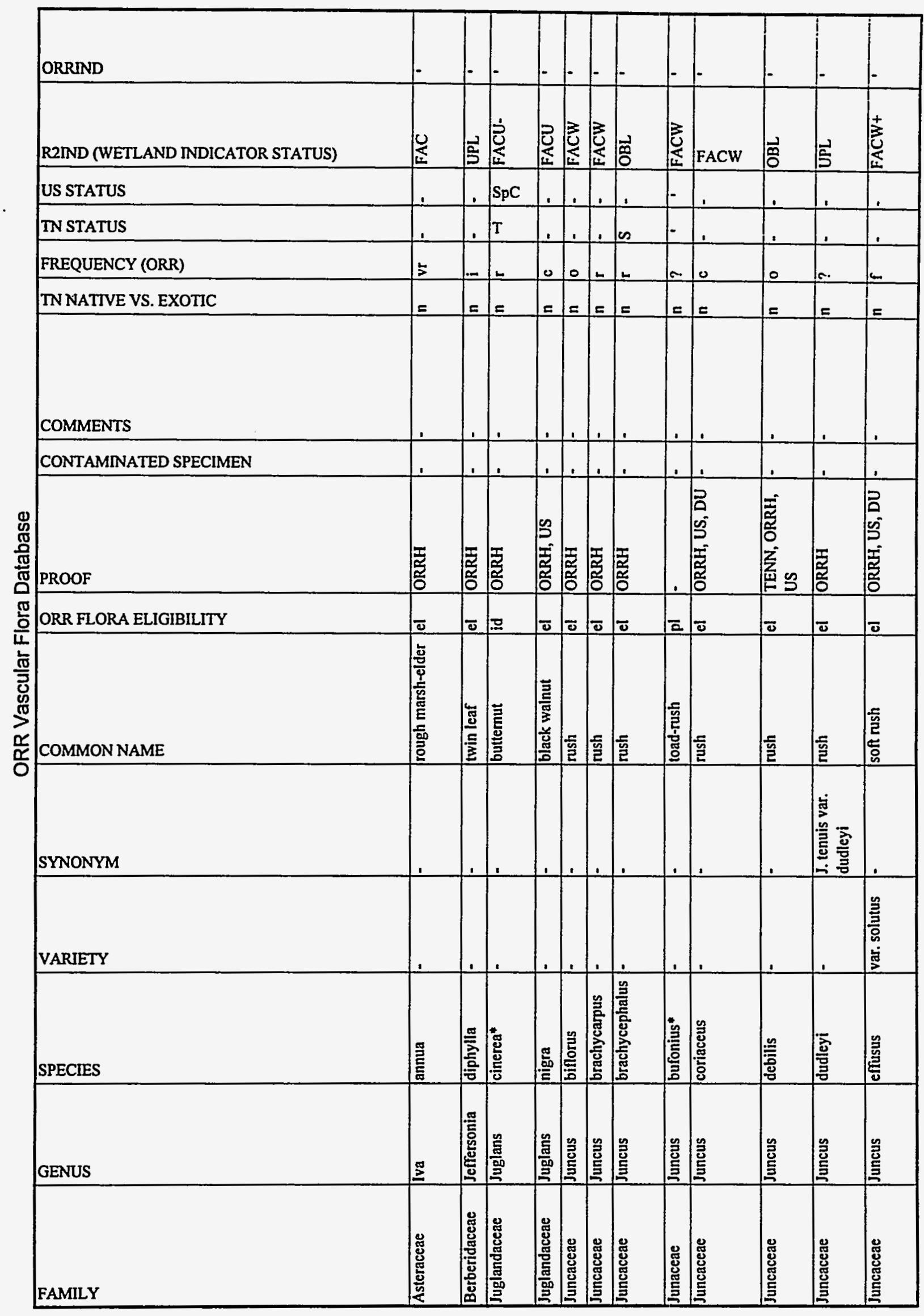




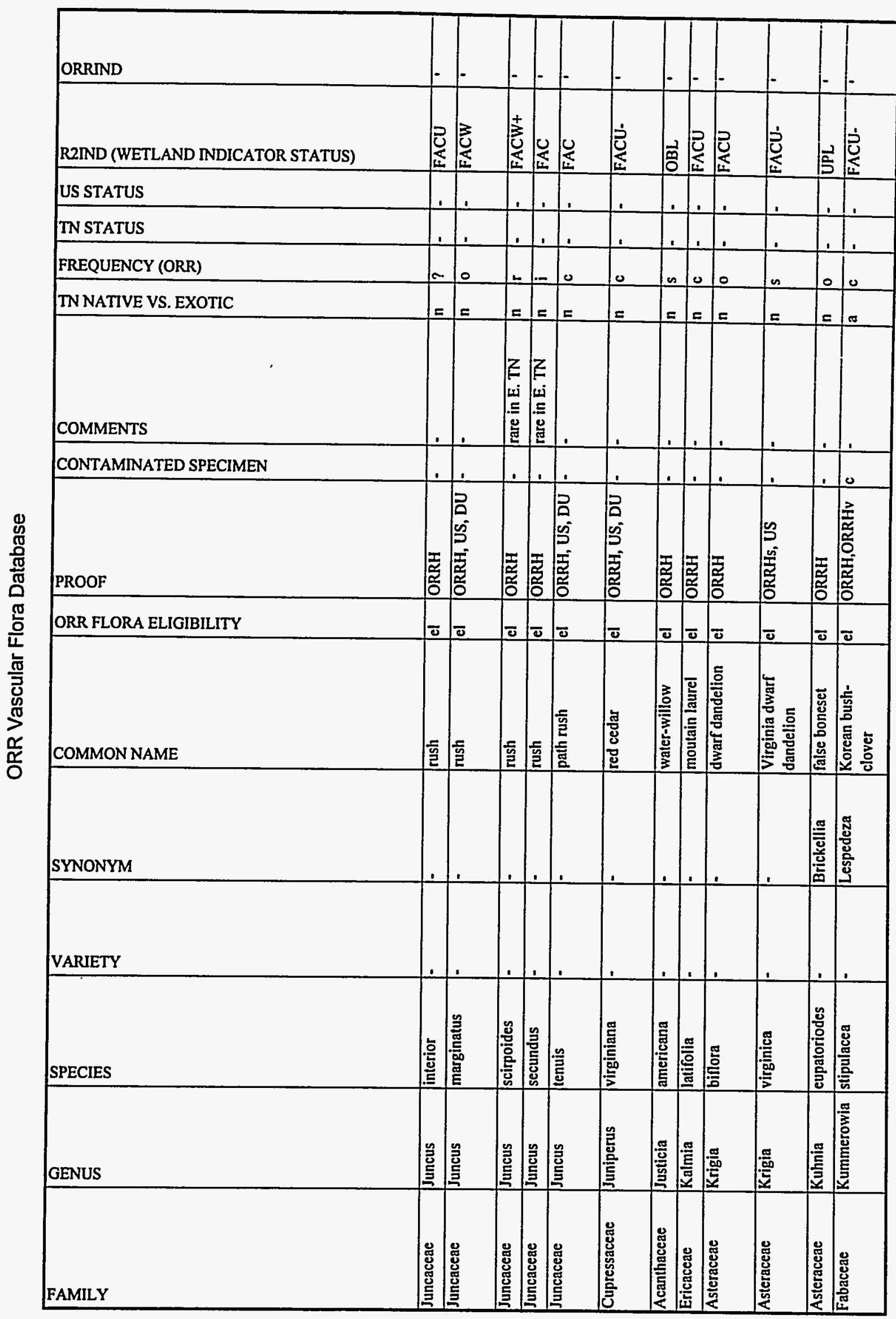




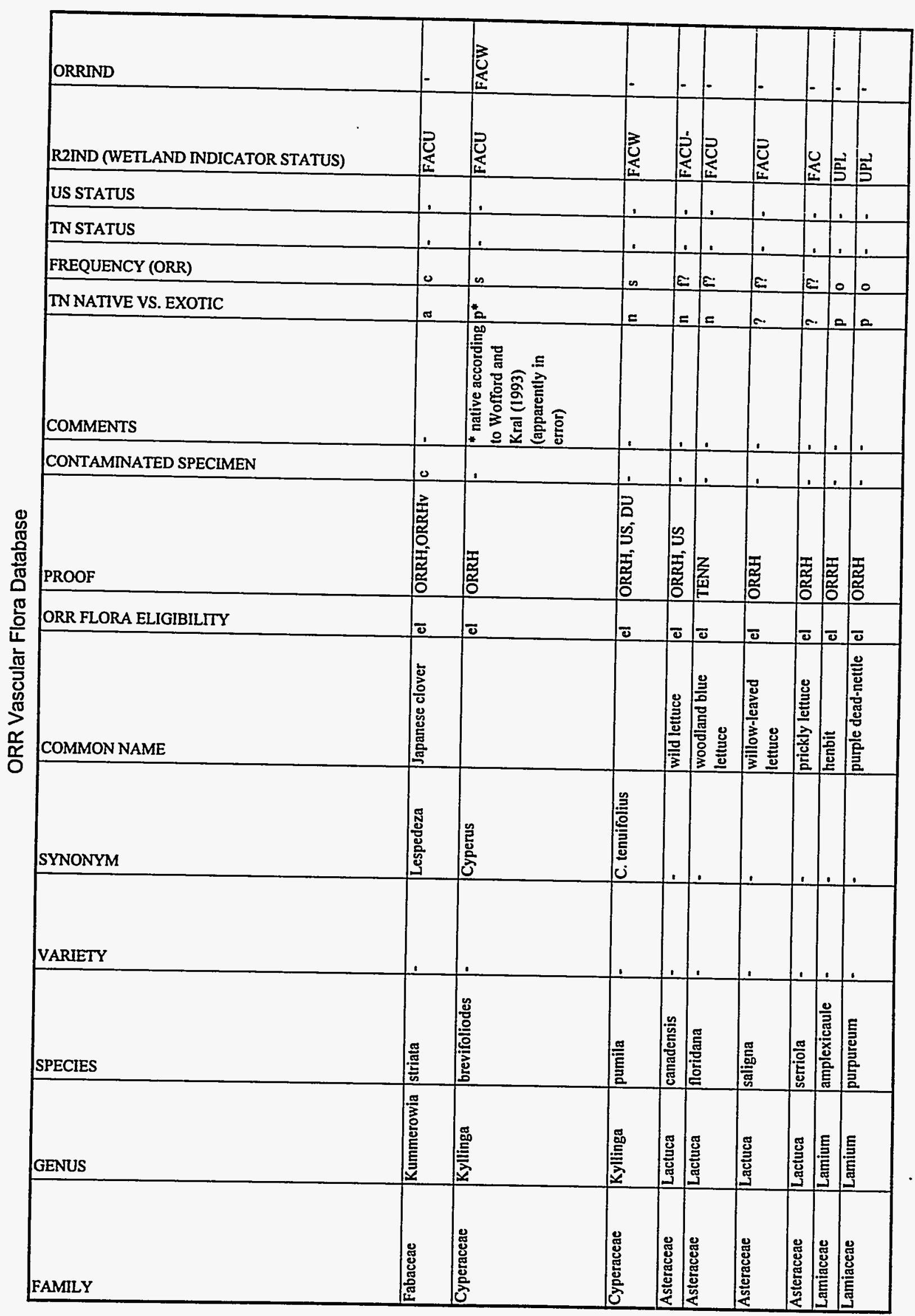




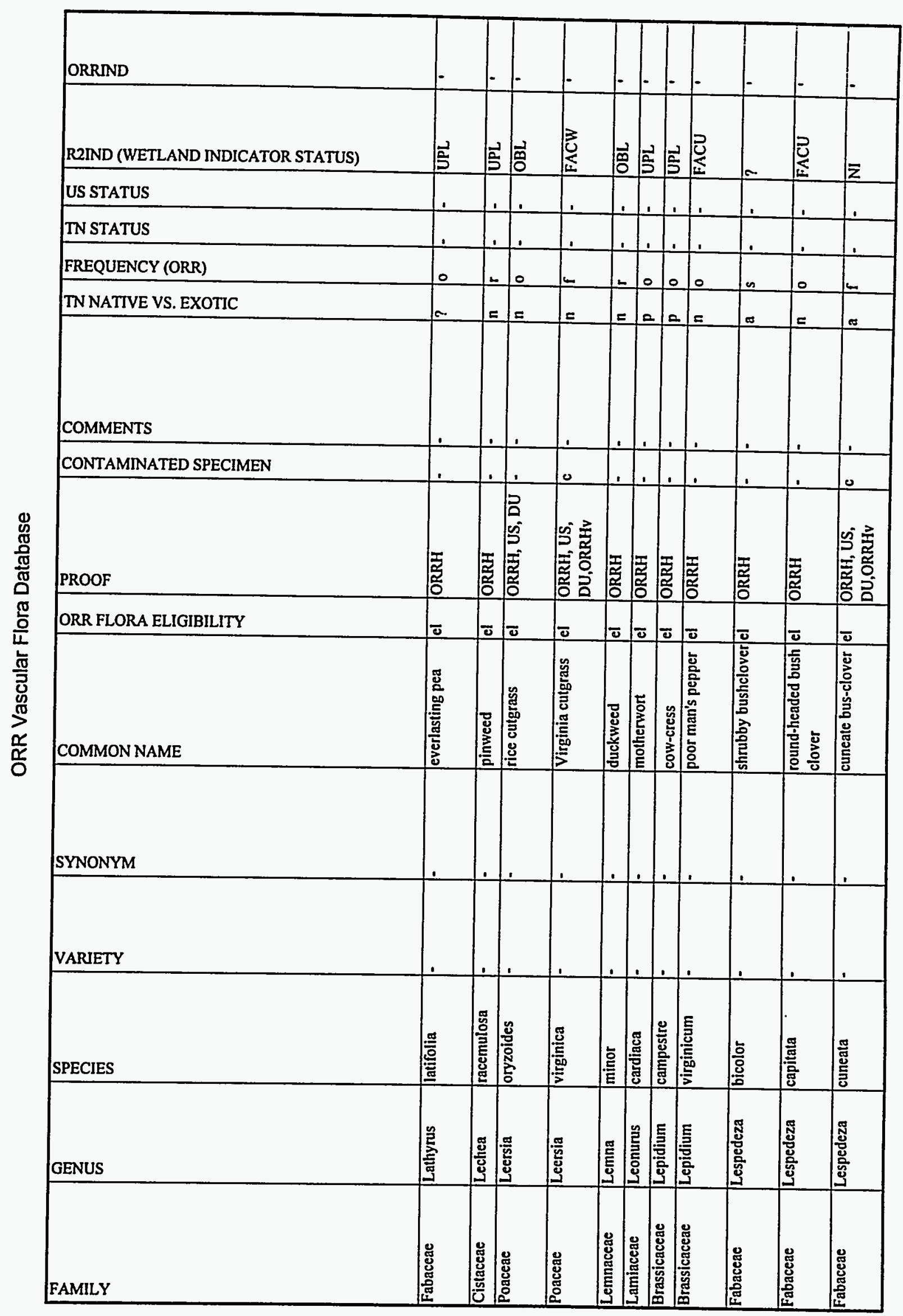




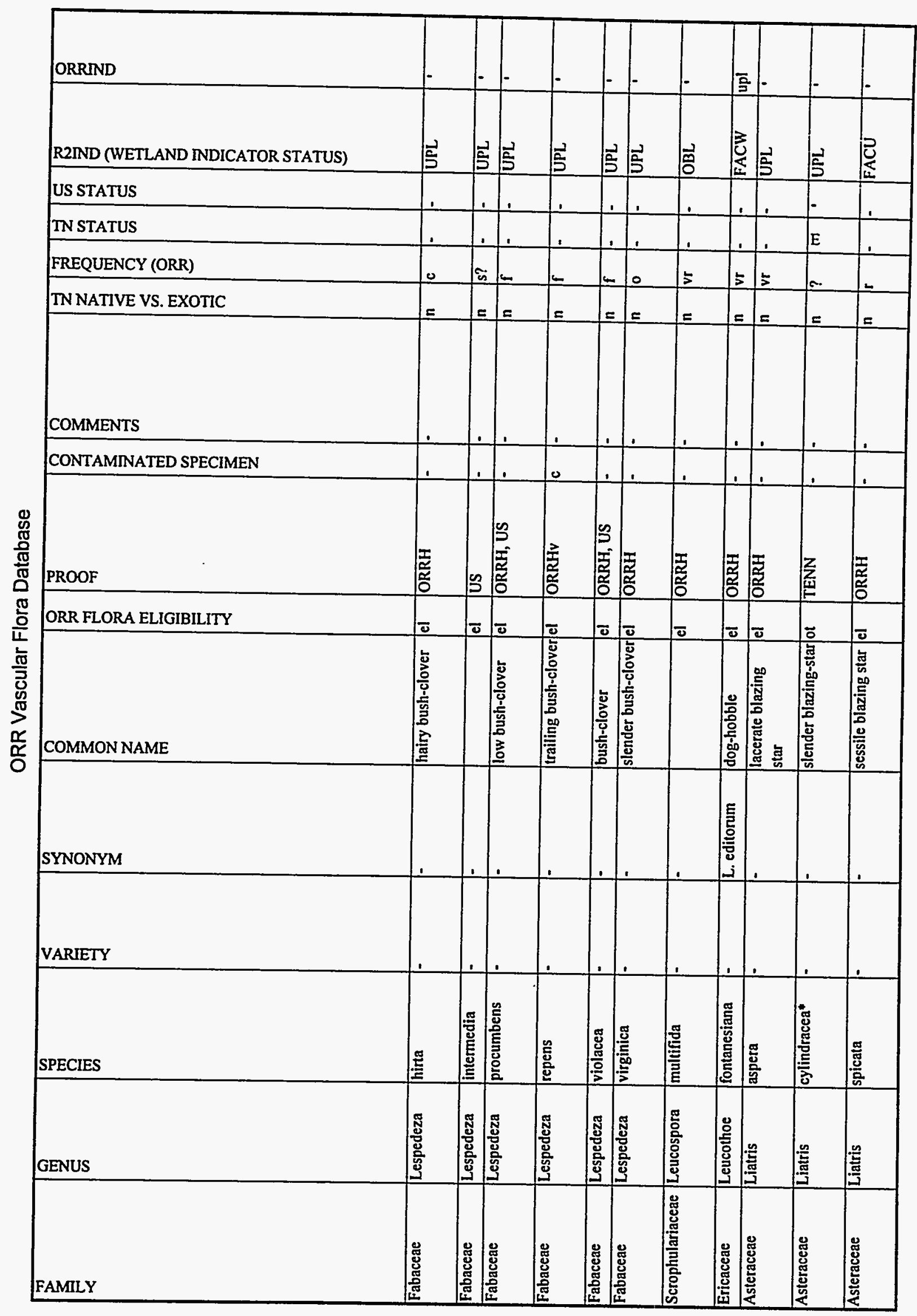




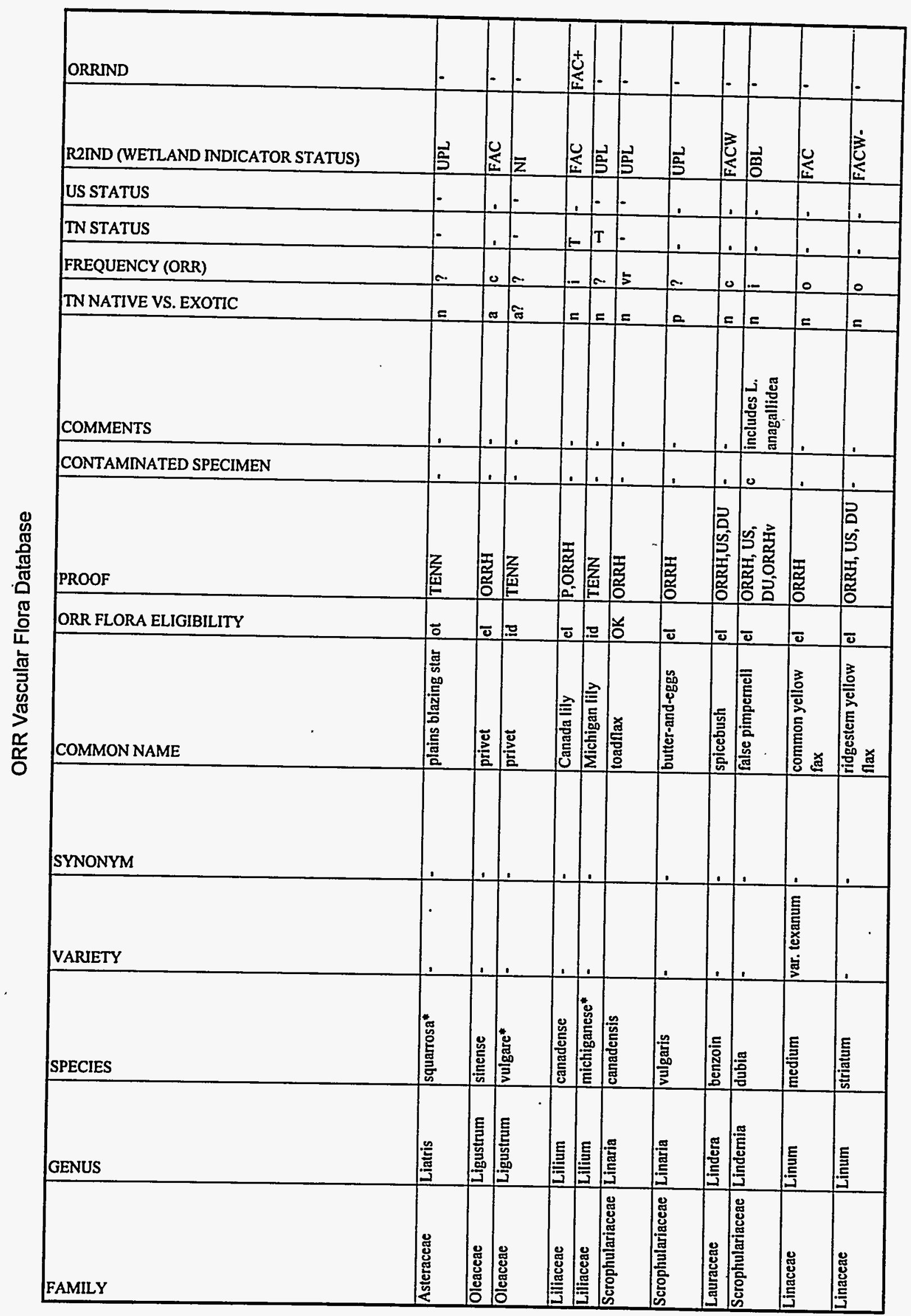




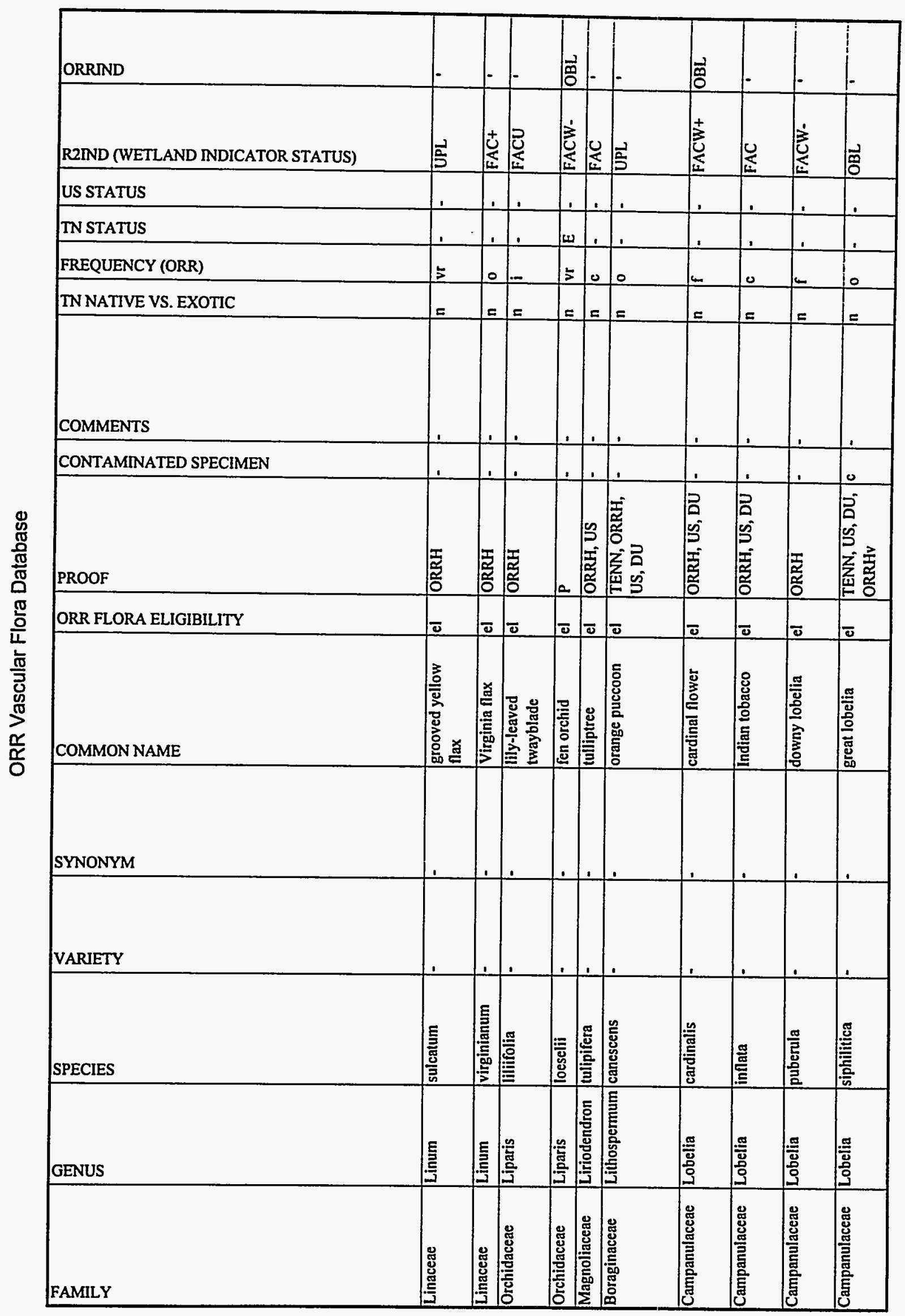


C-75

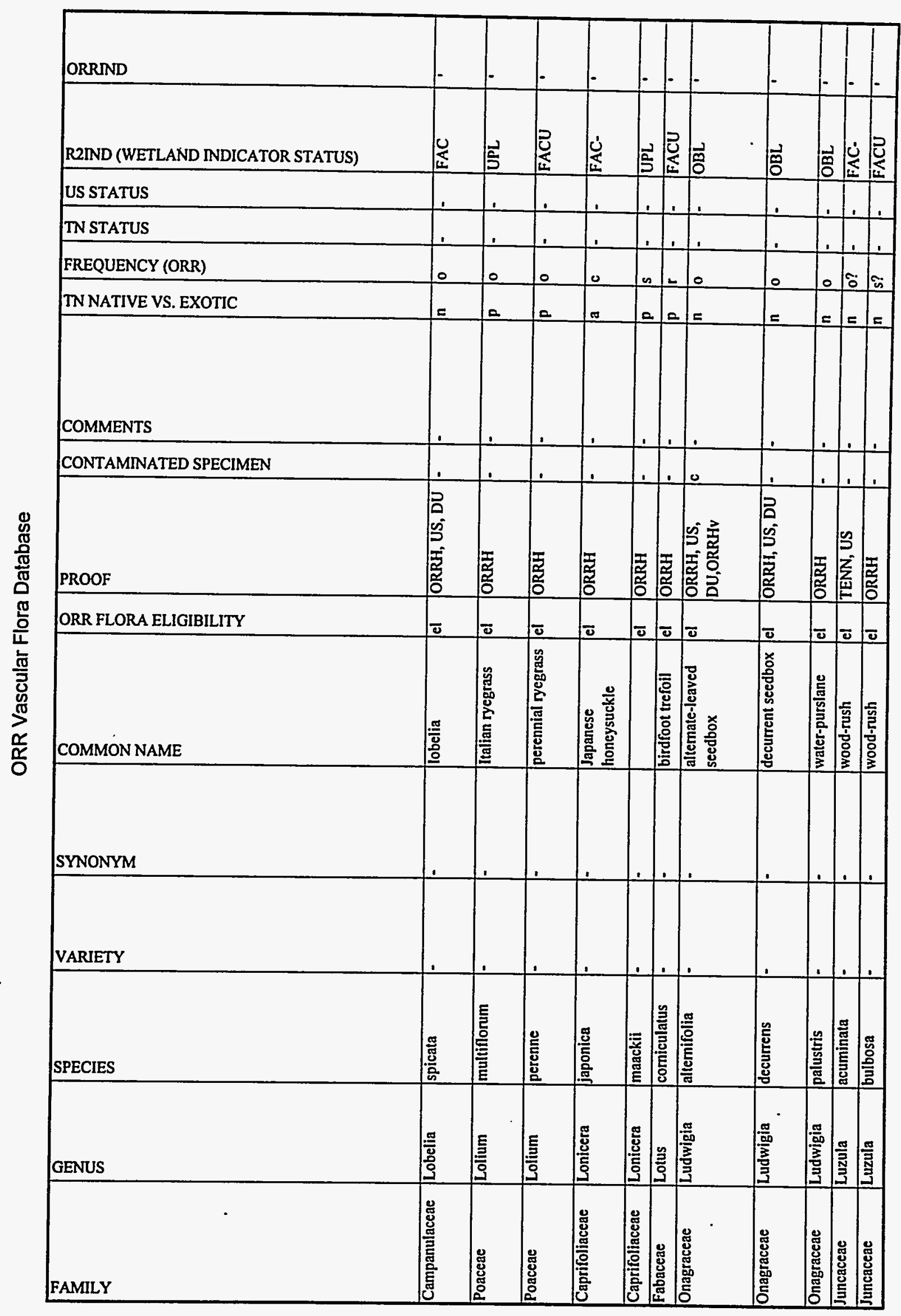




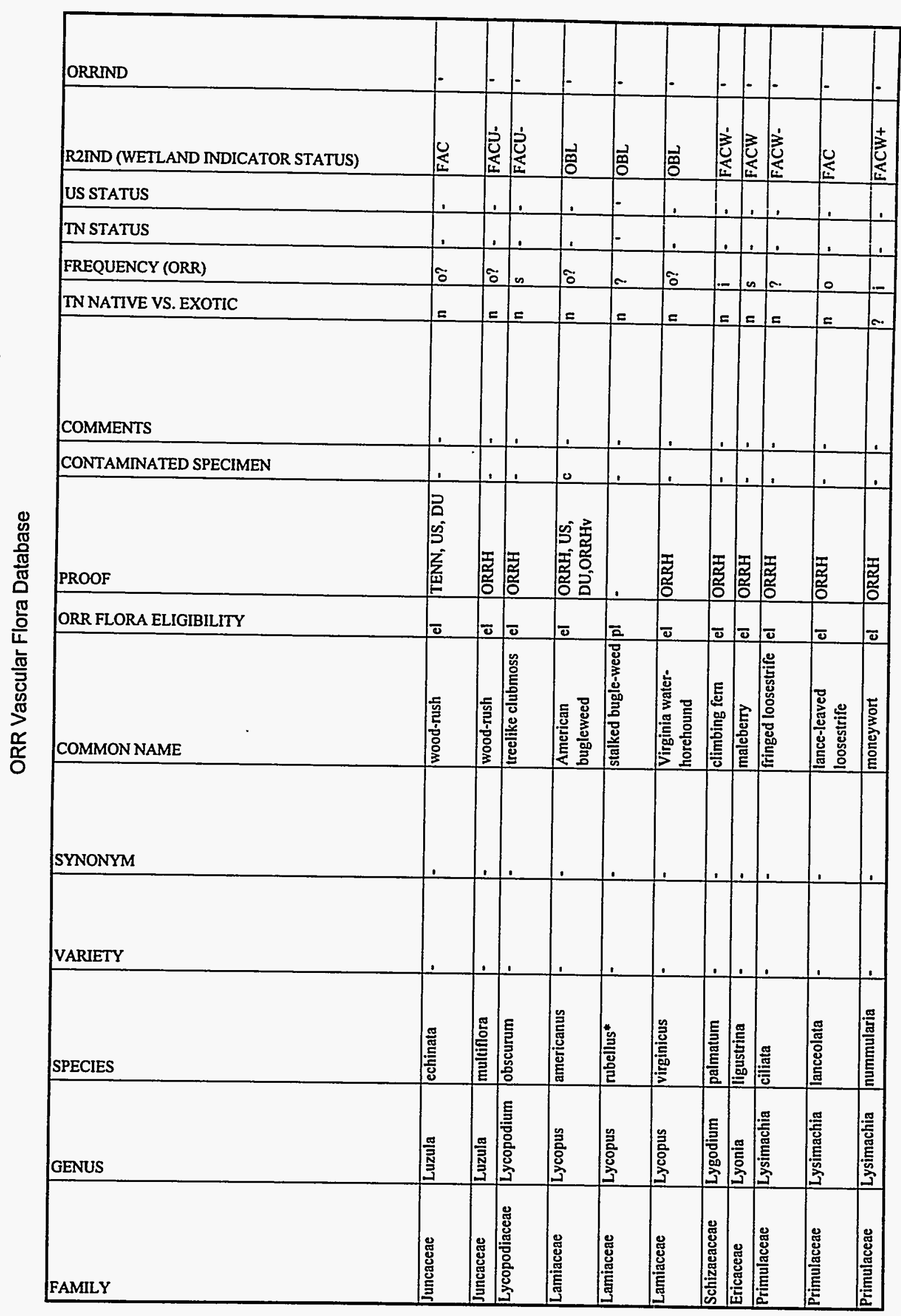




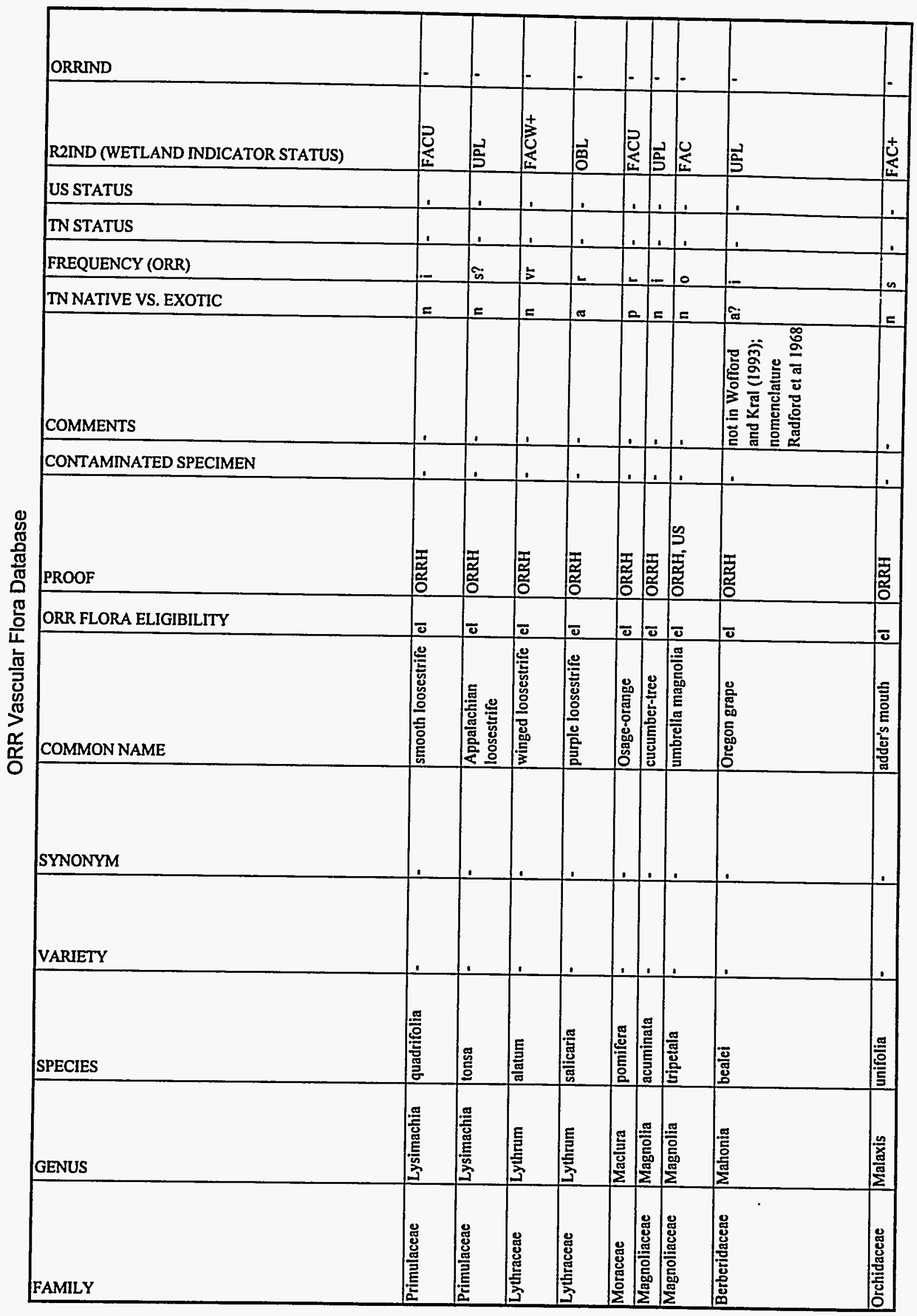




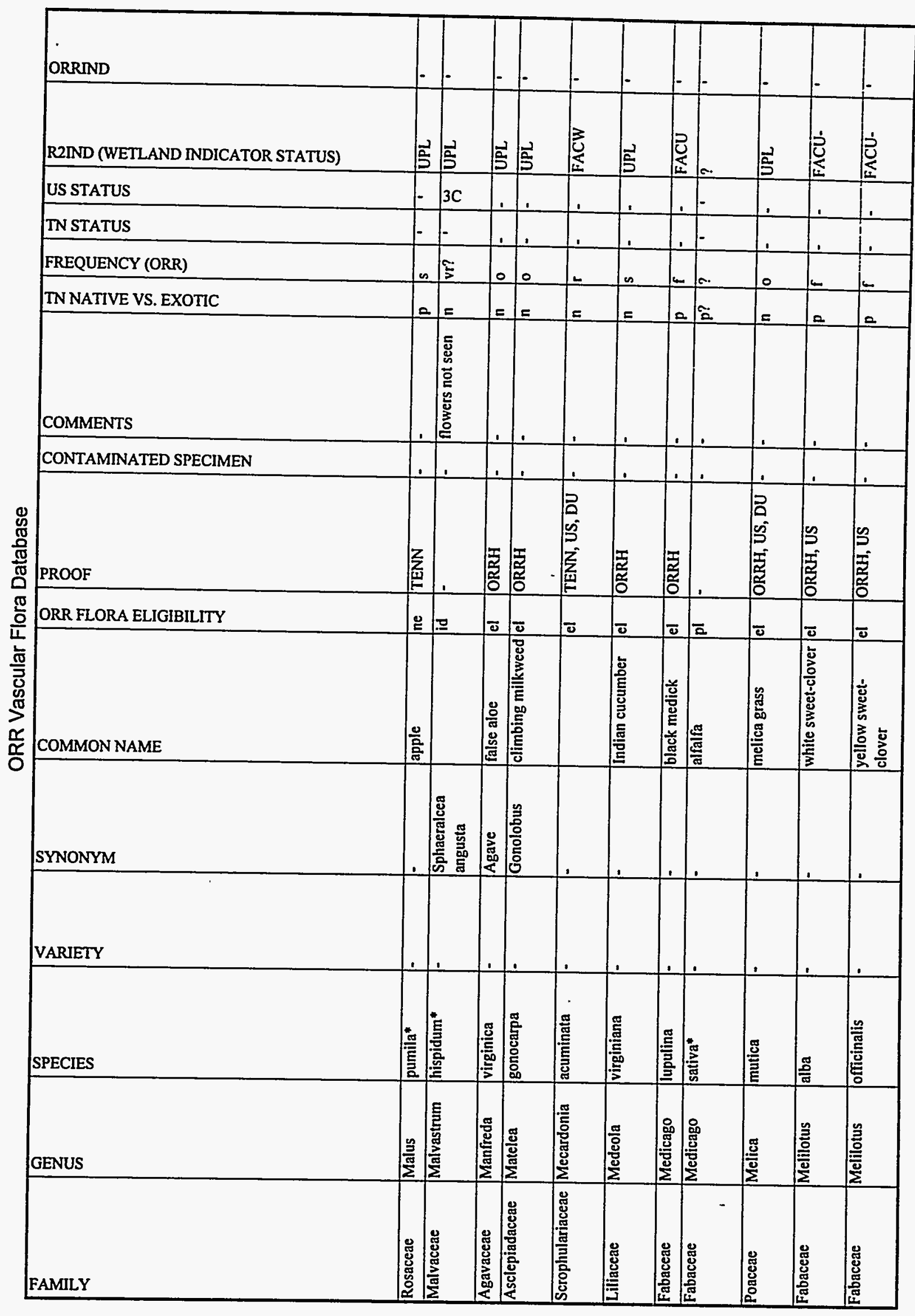




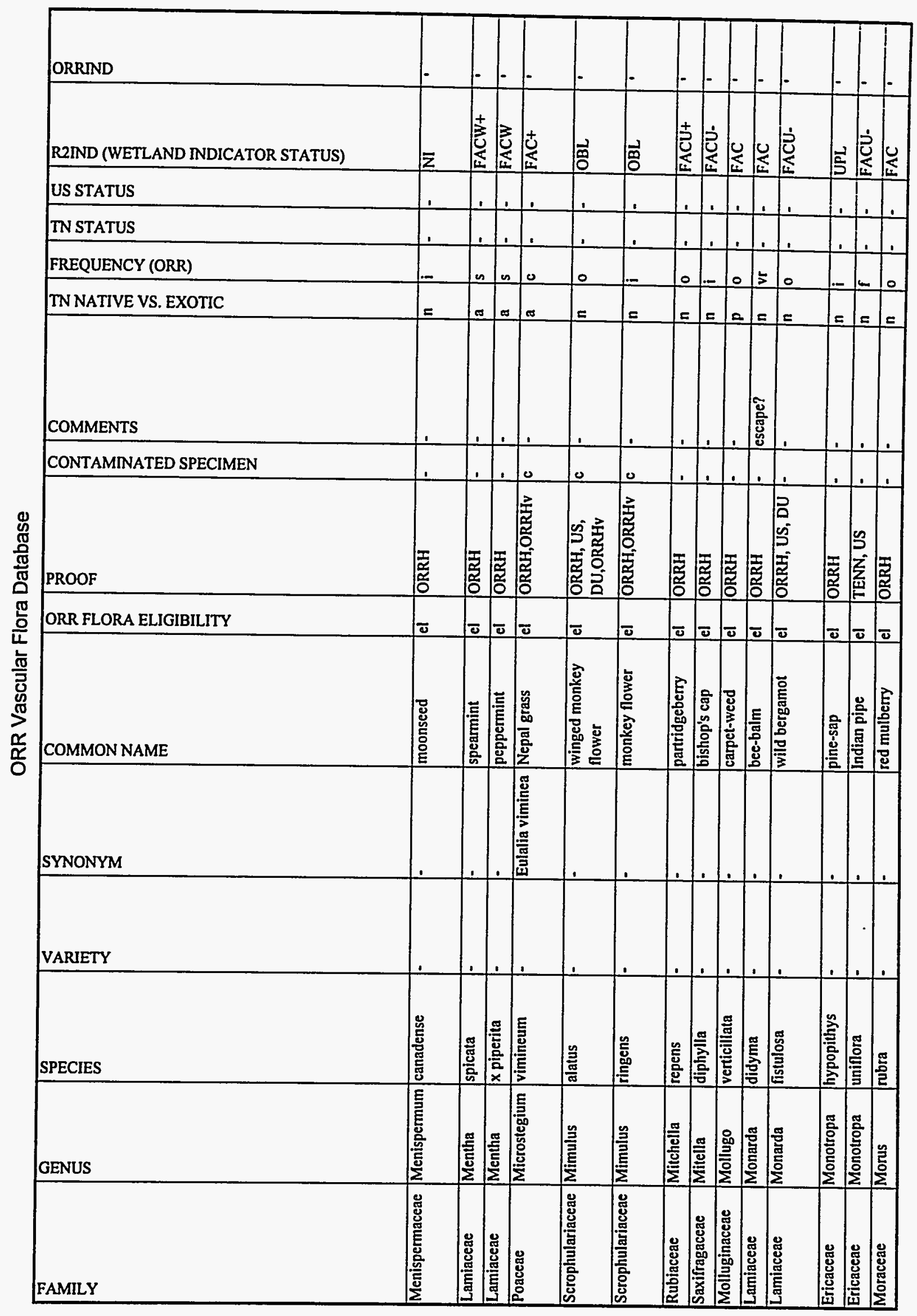




\section{C-80}

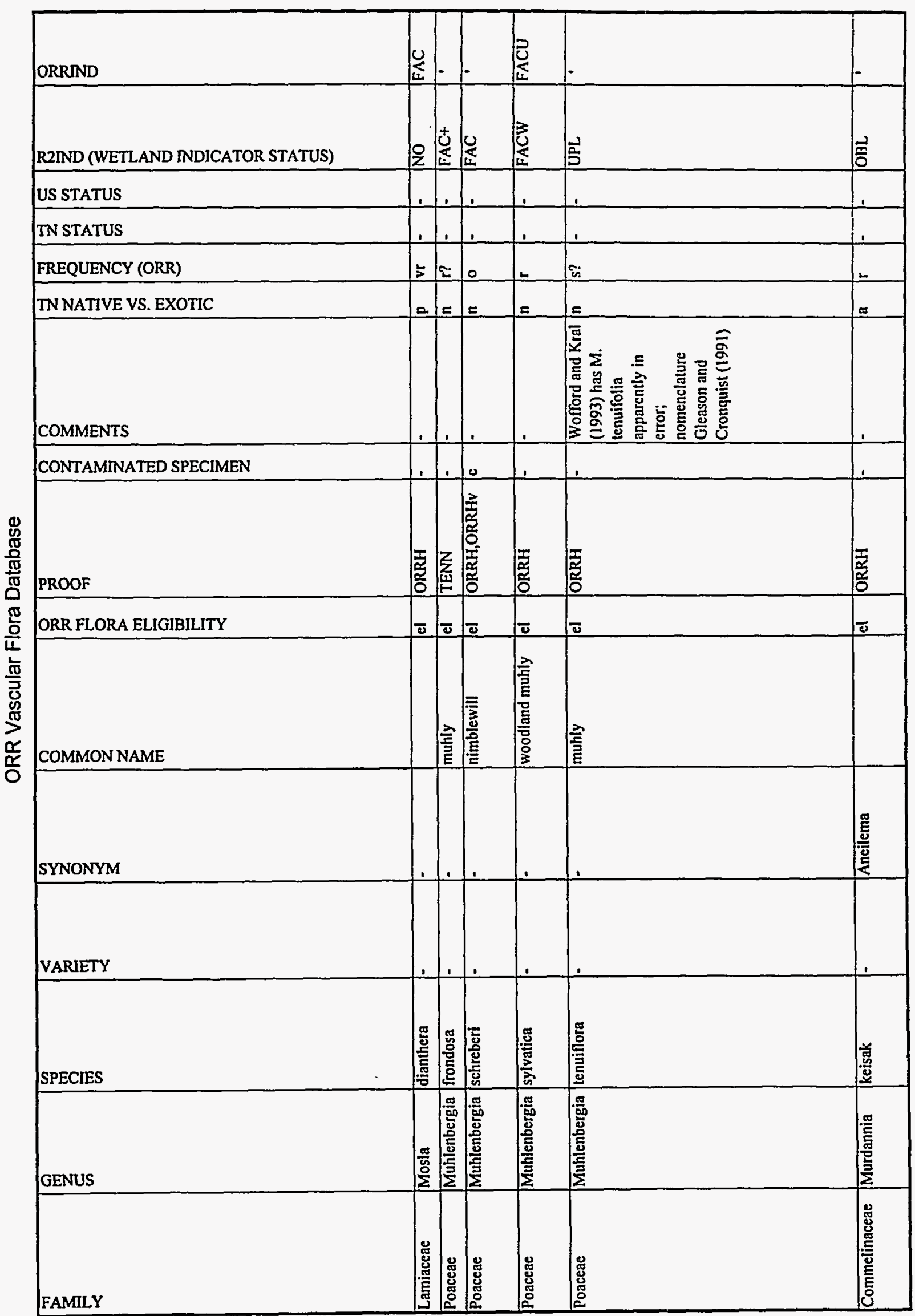


C-81

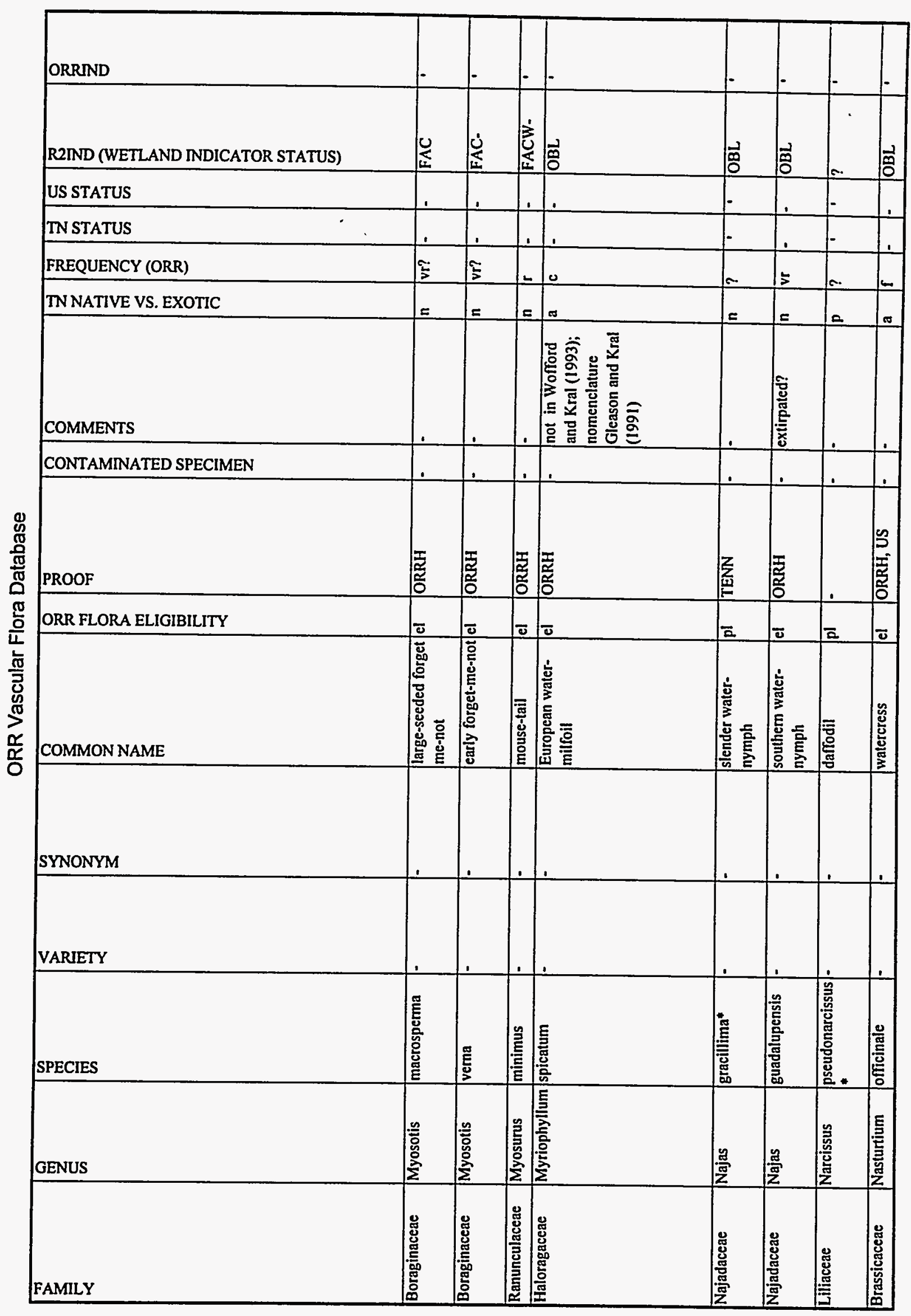




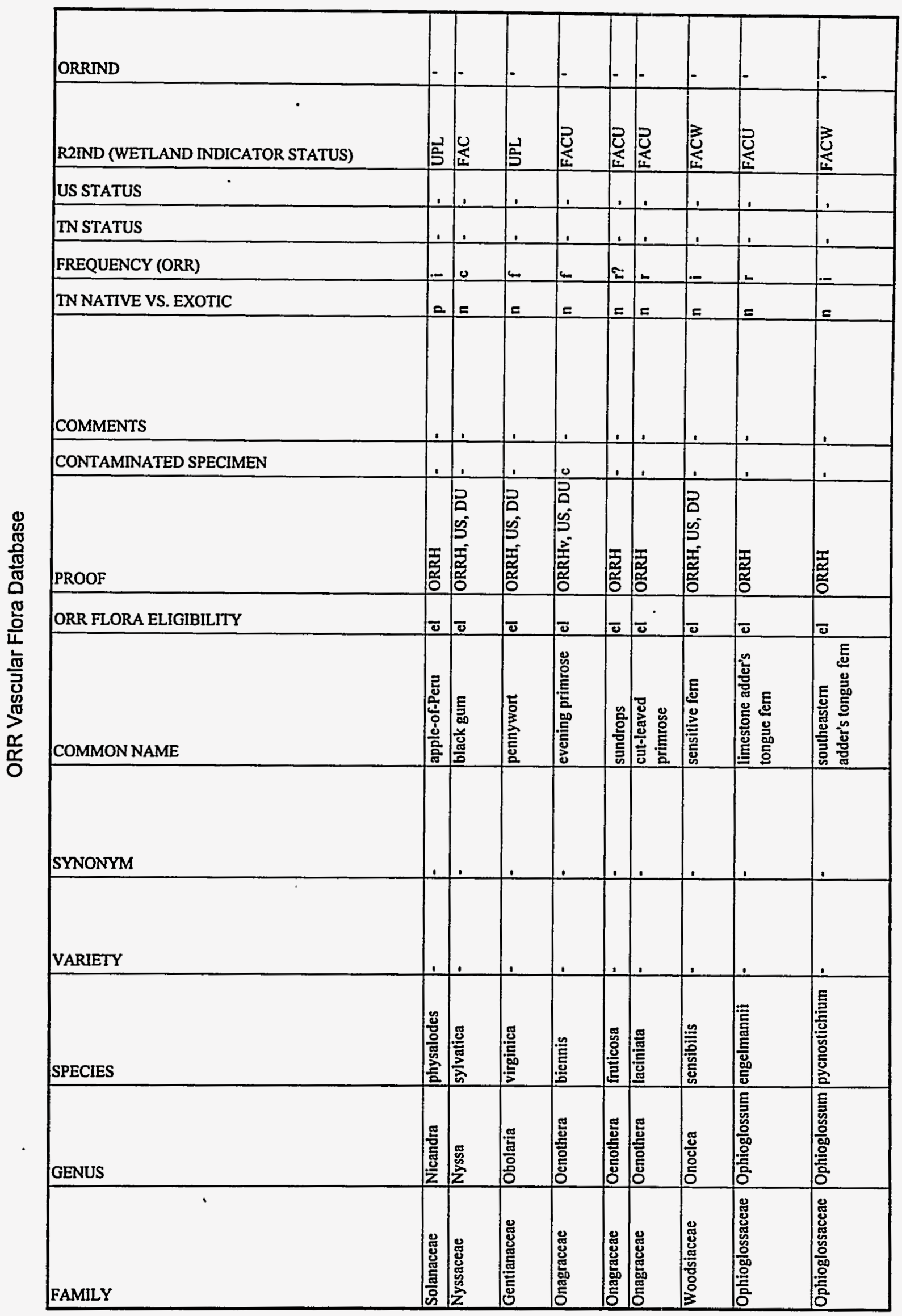




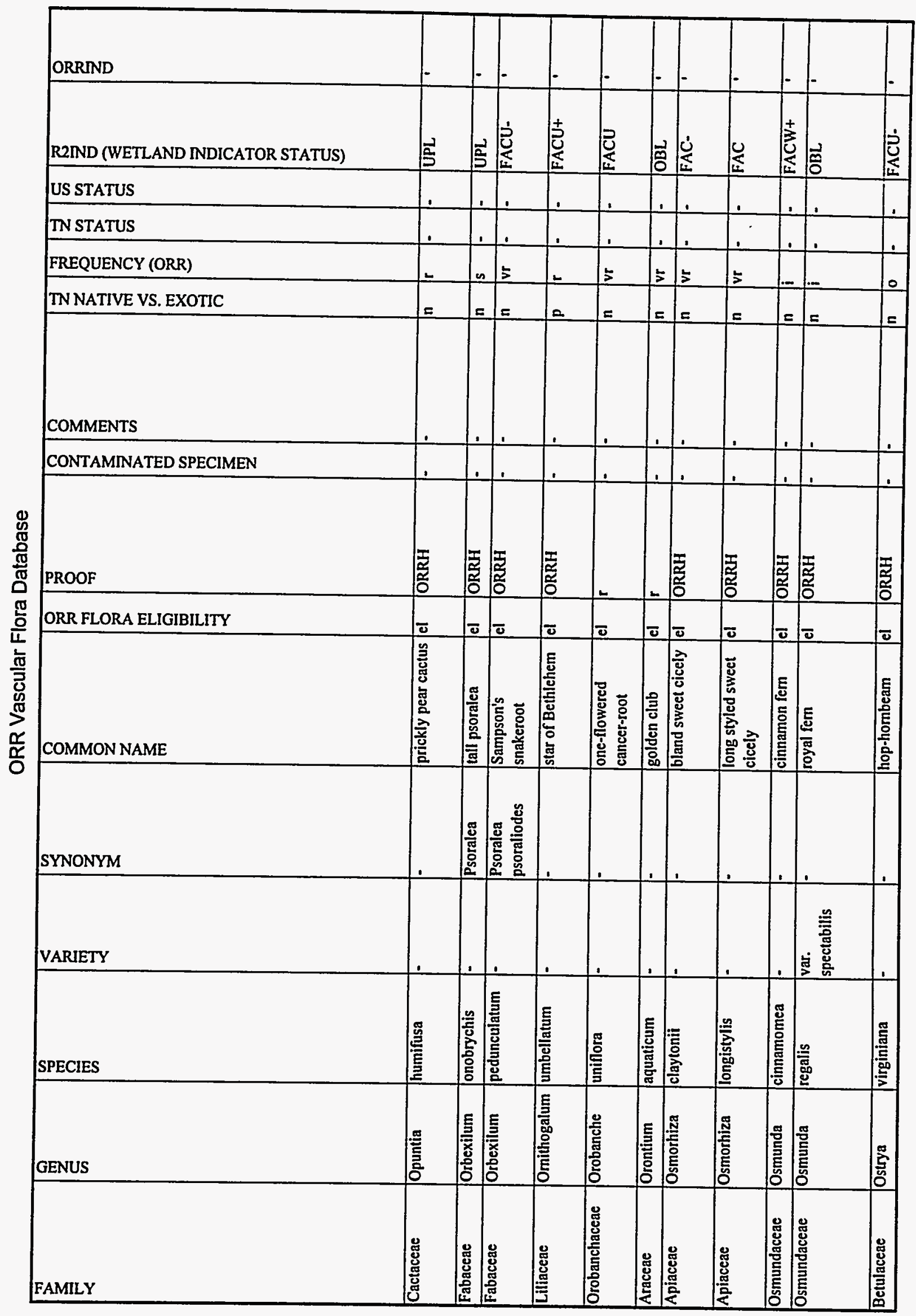




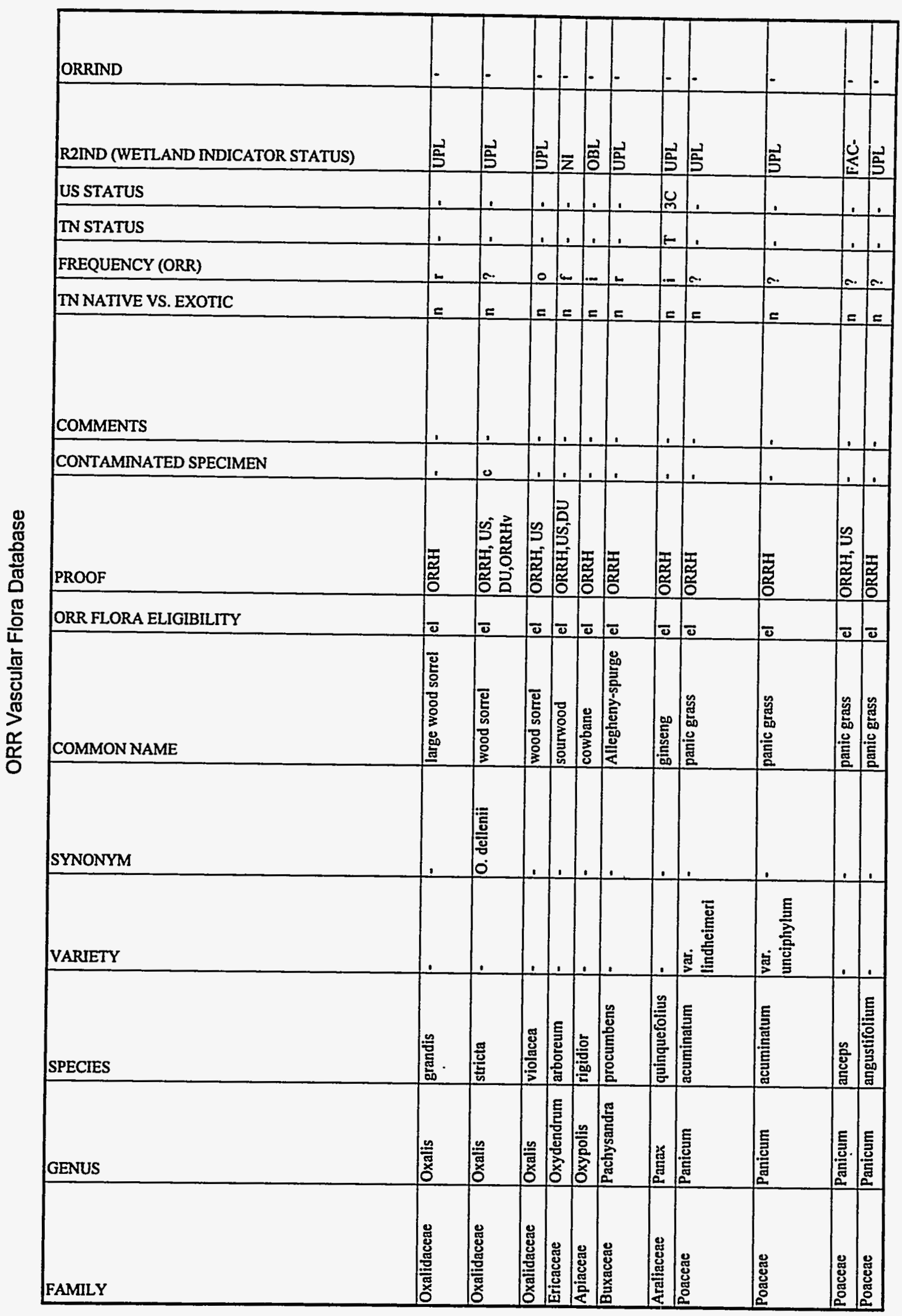




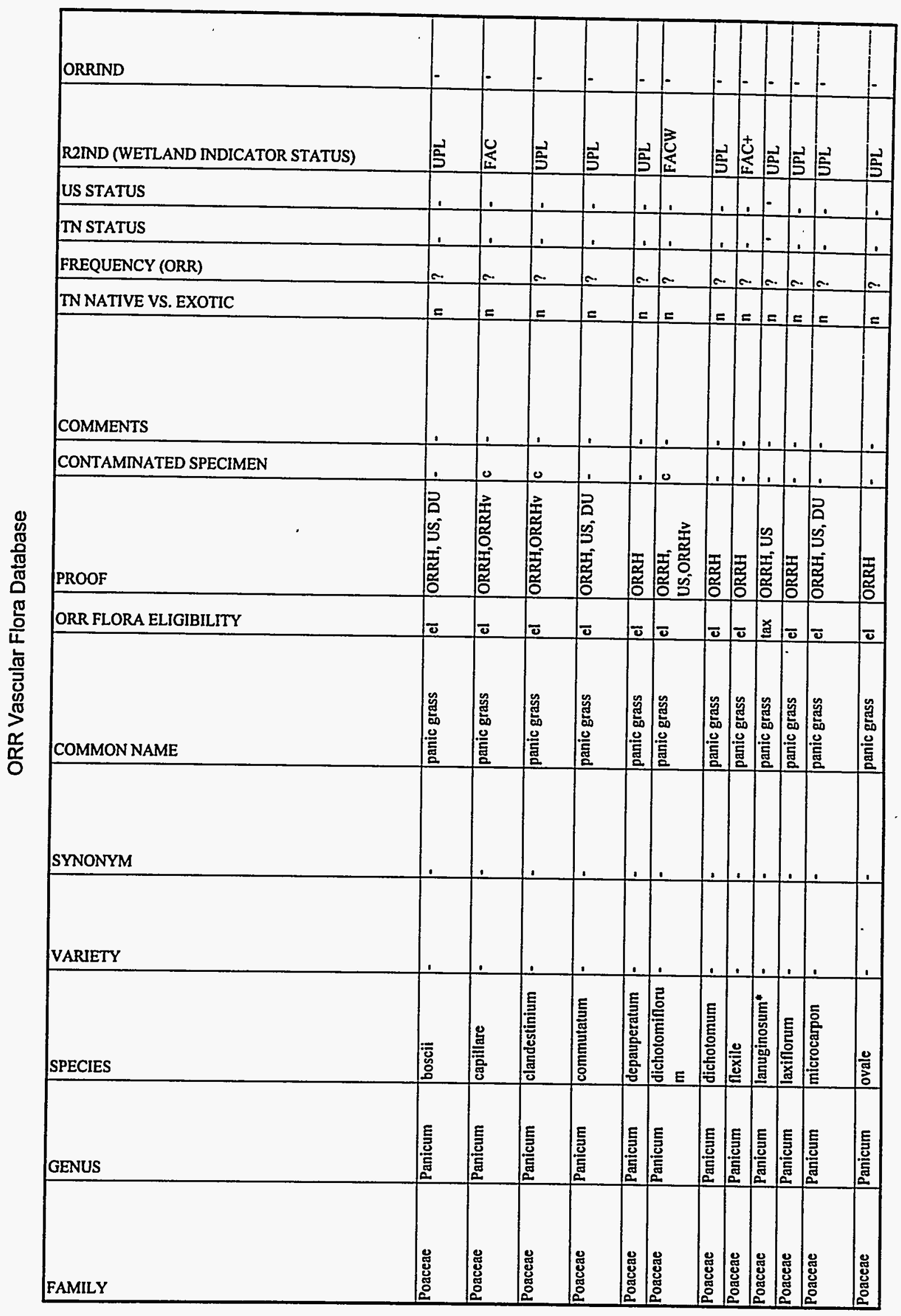




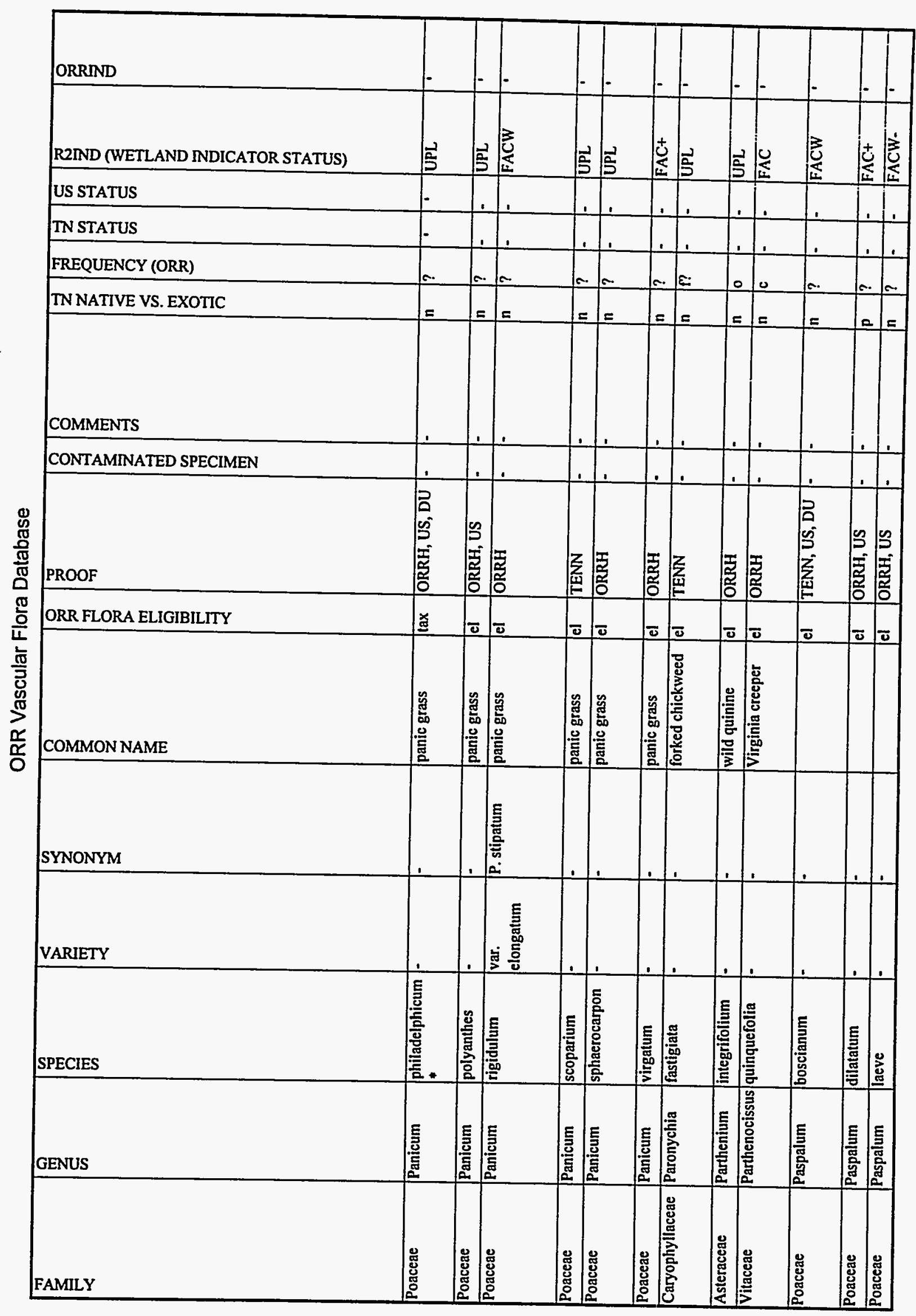




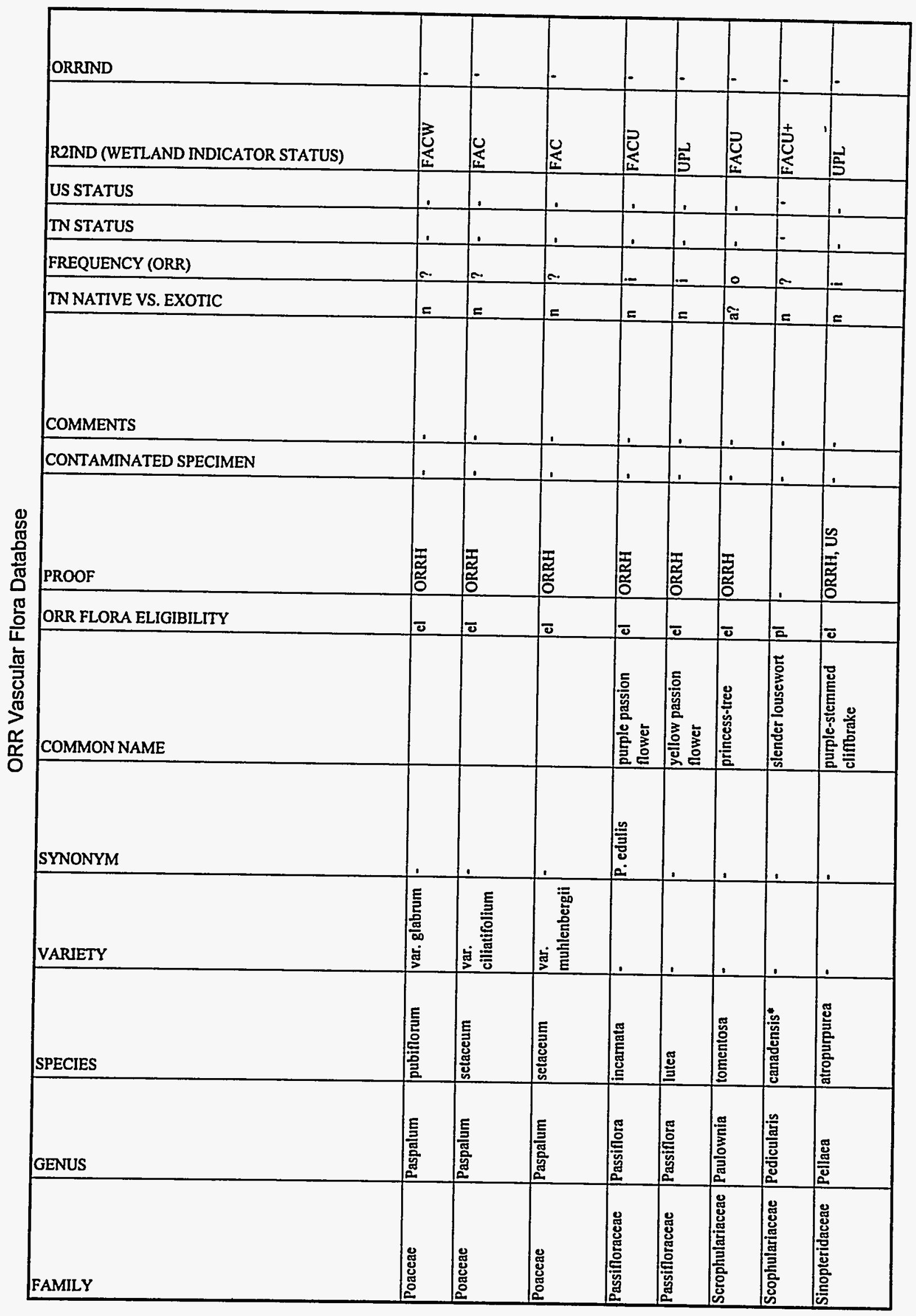




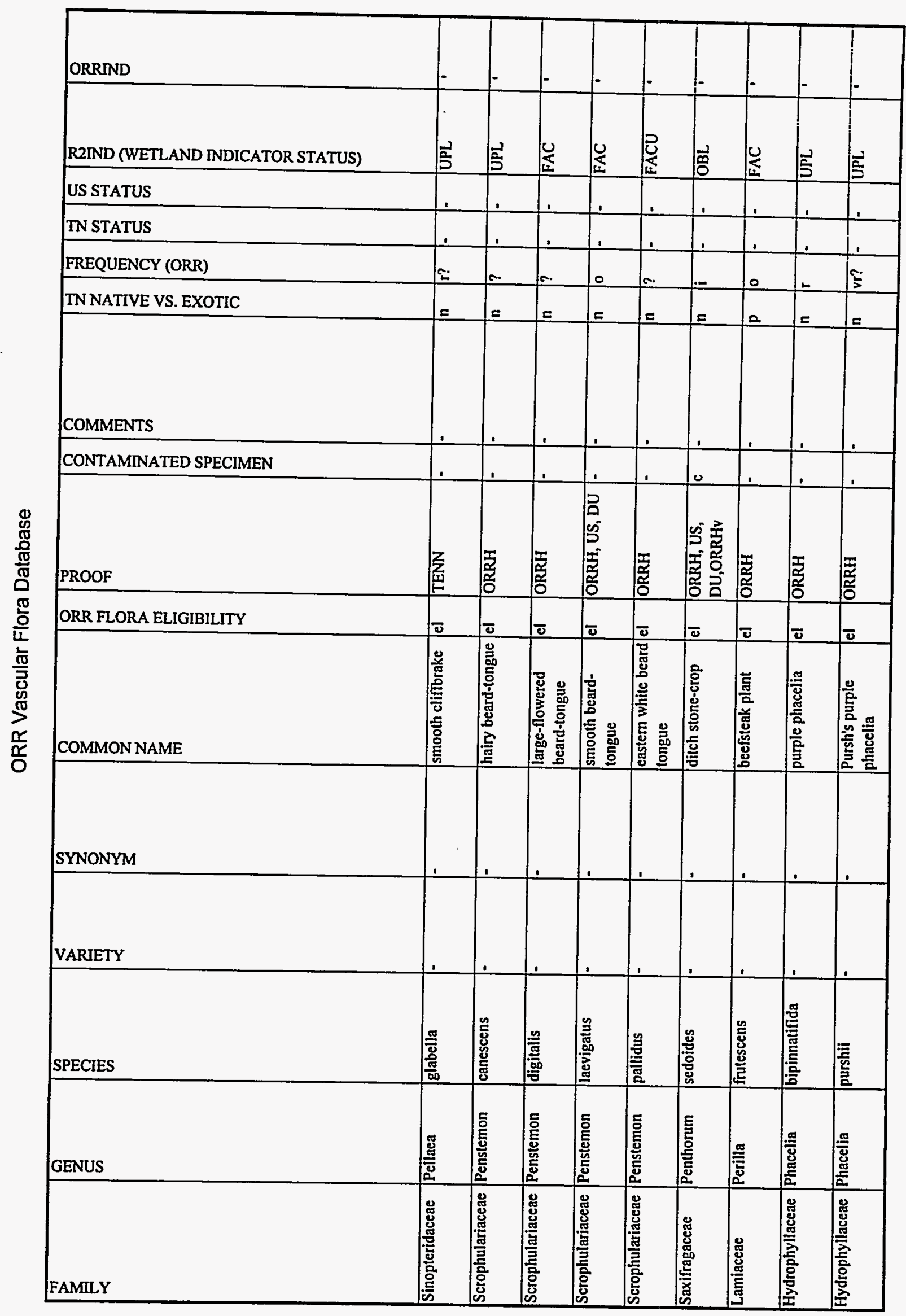




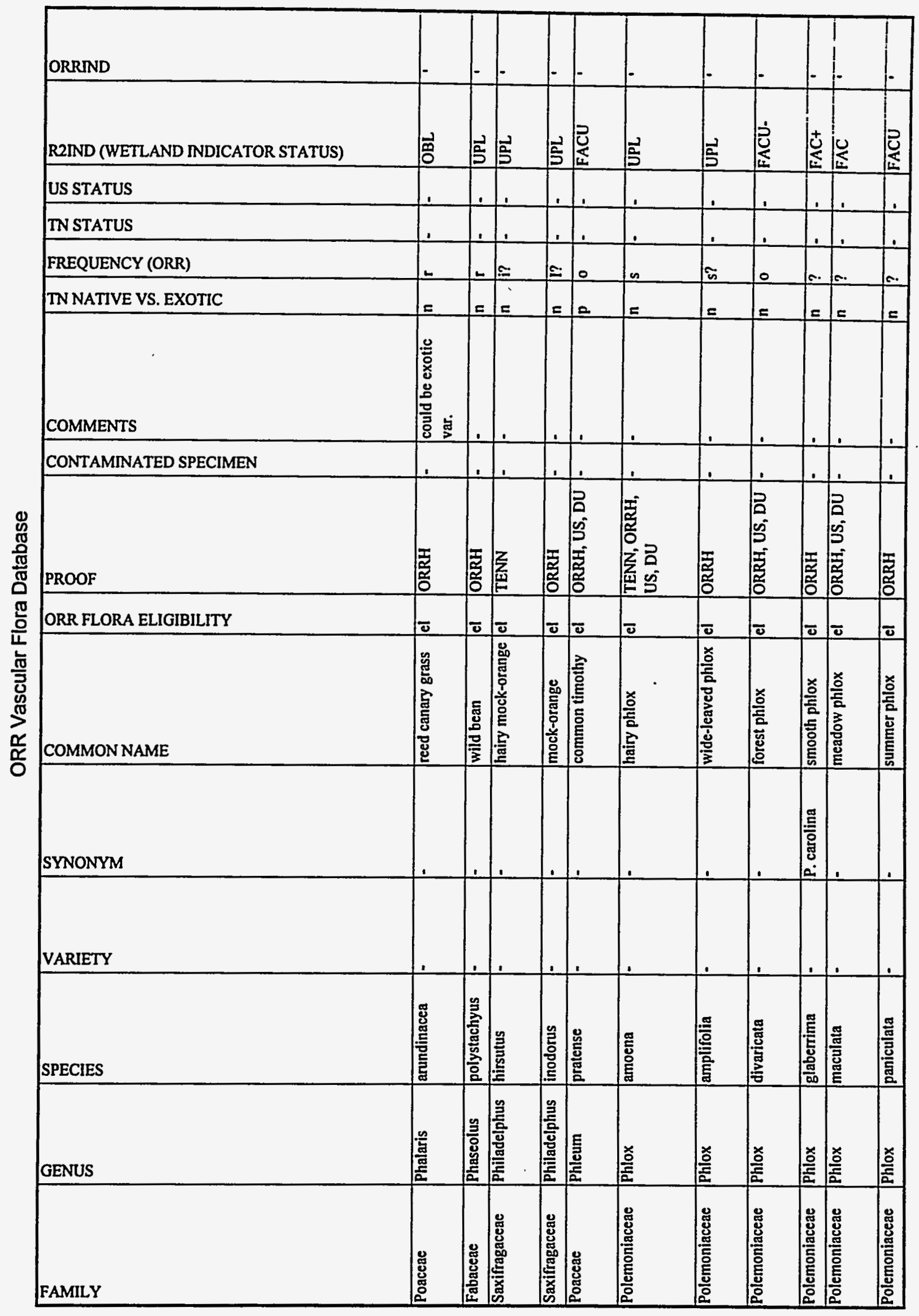




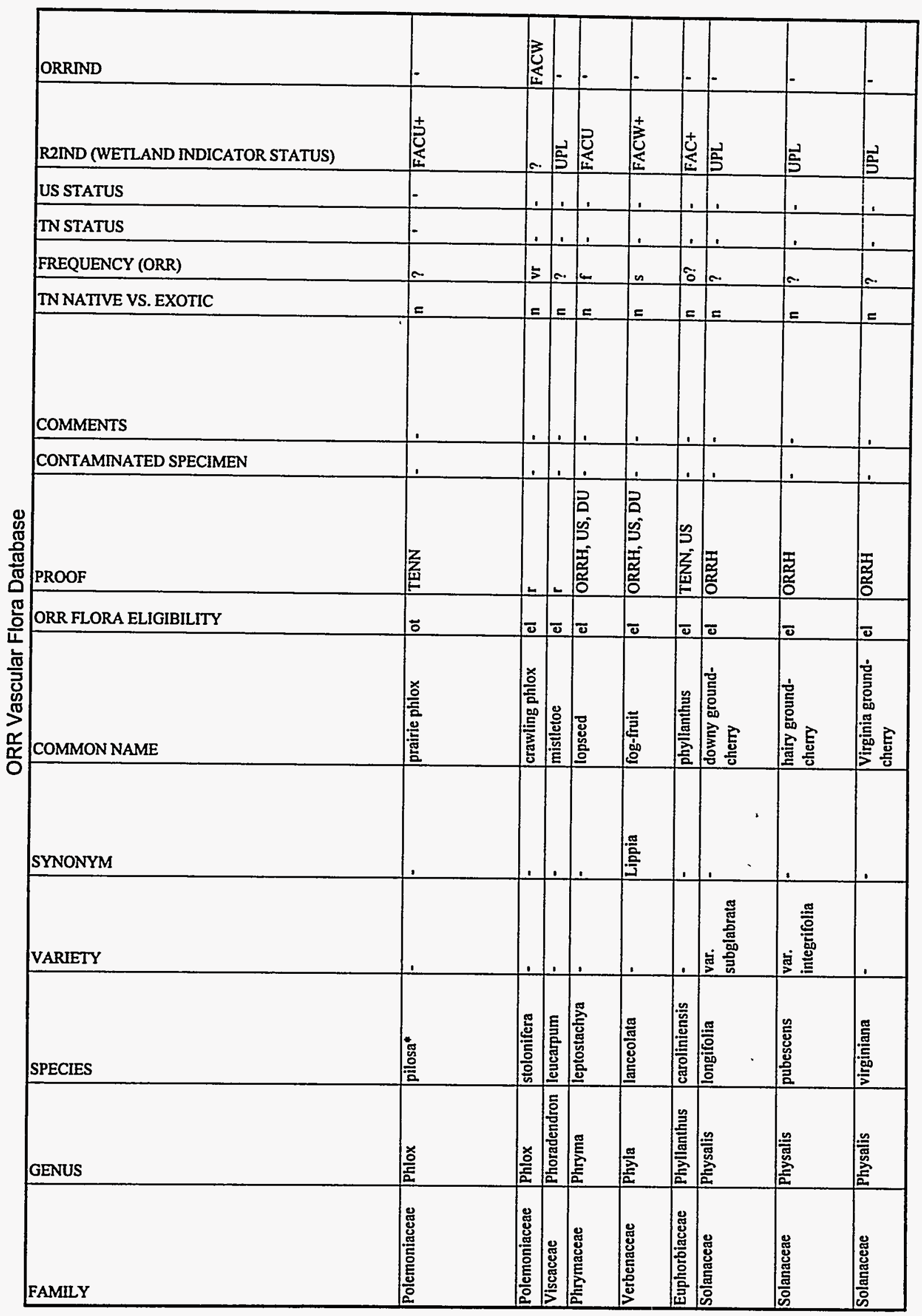




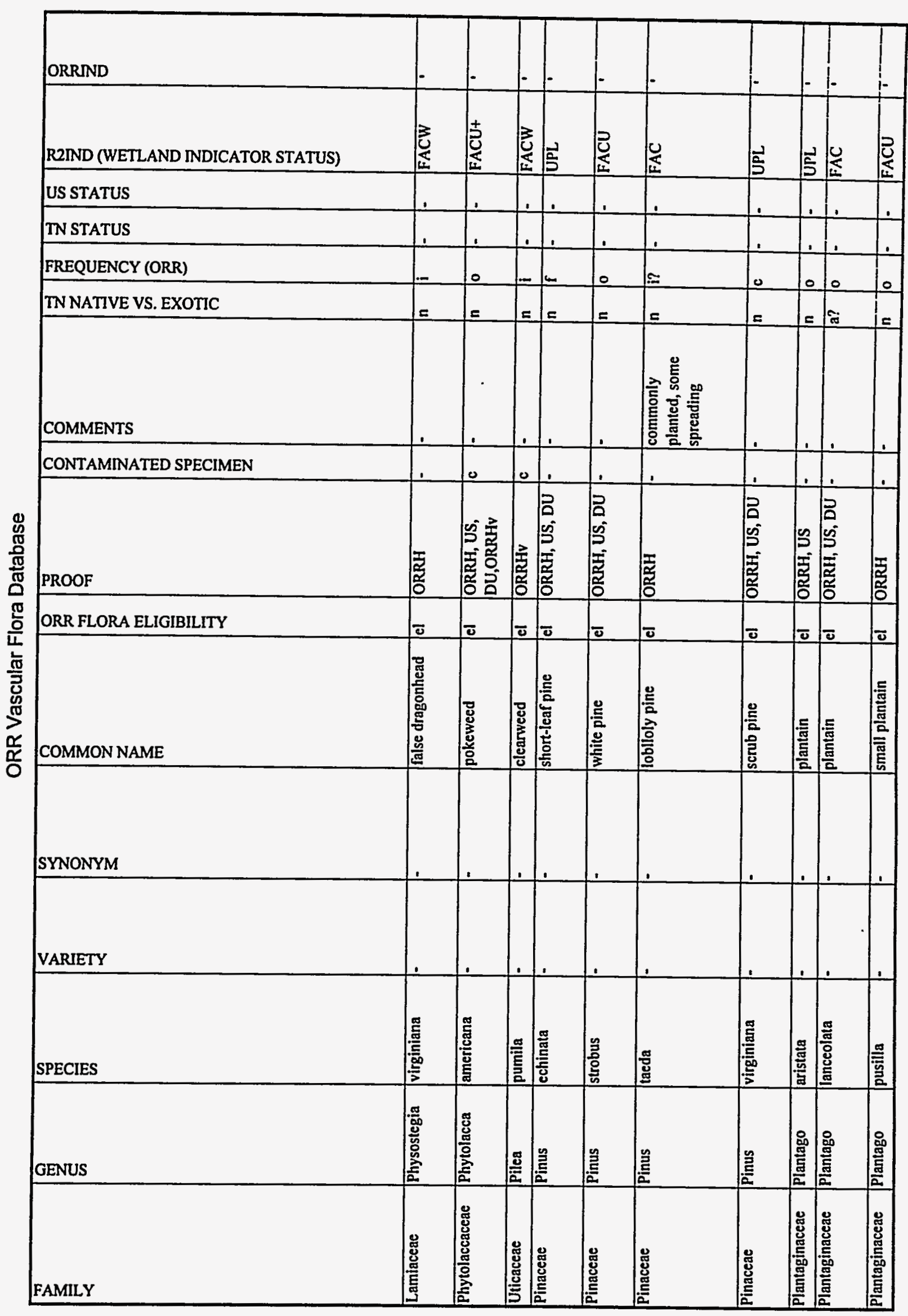




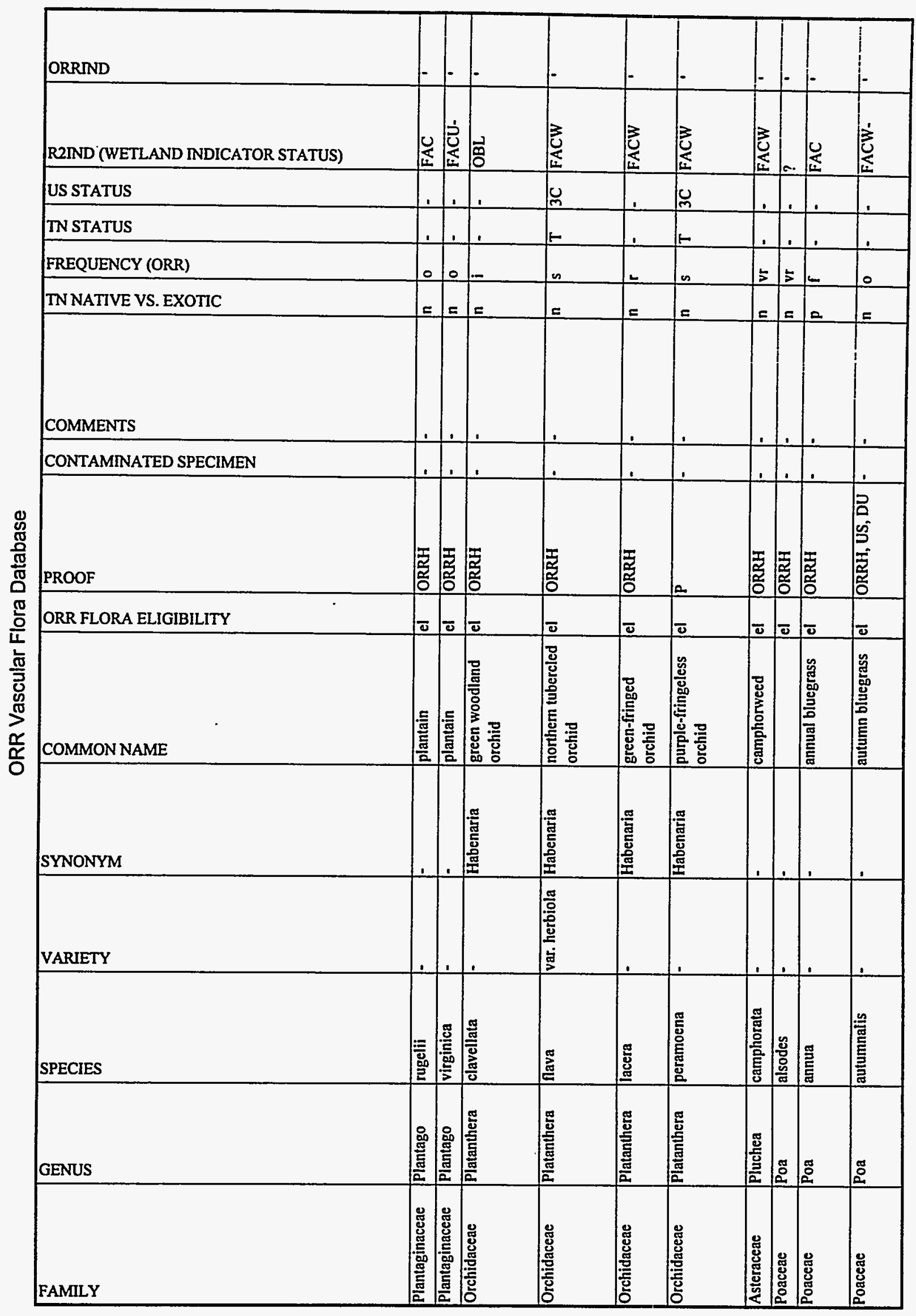




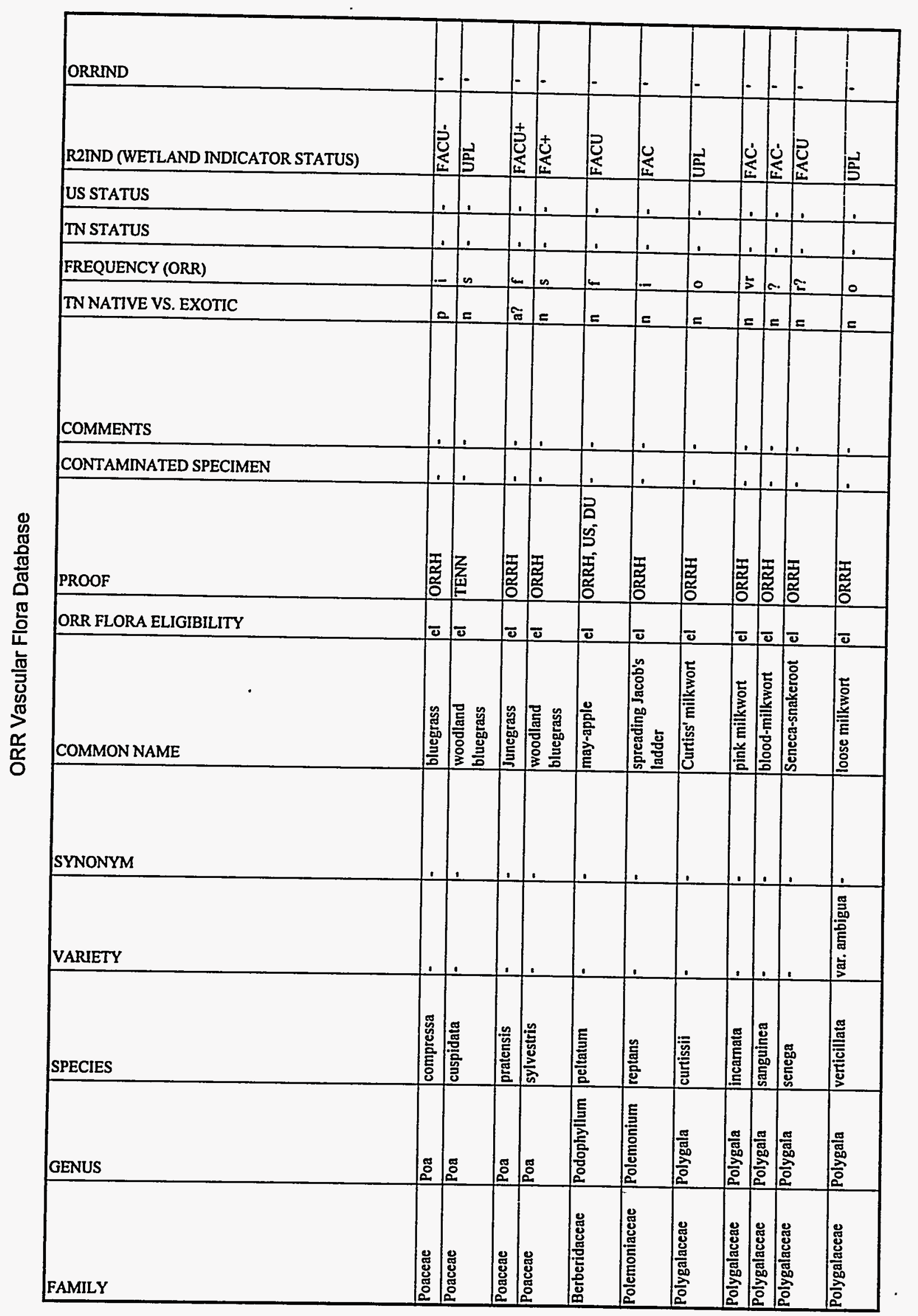




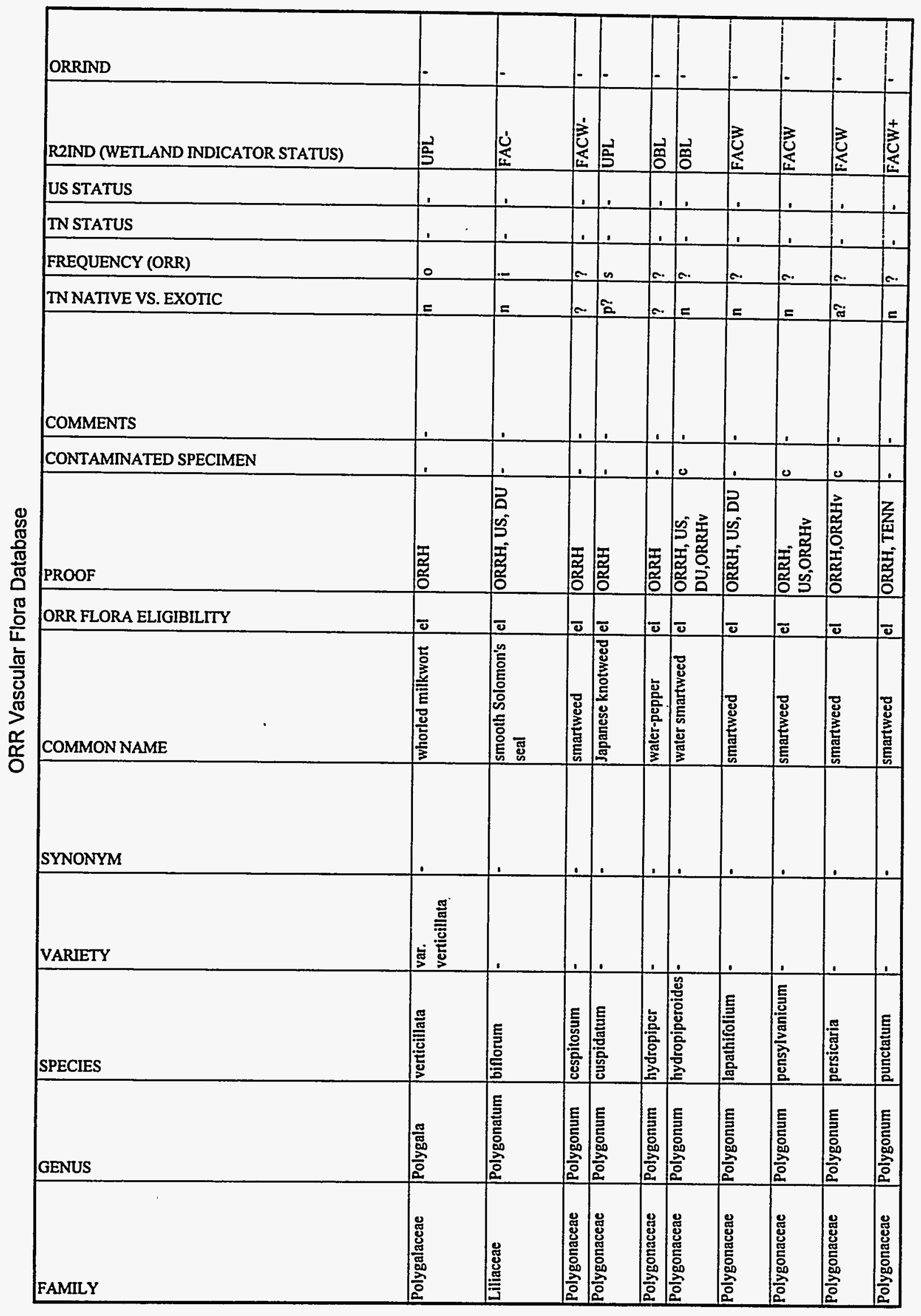




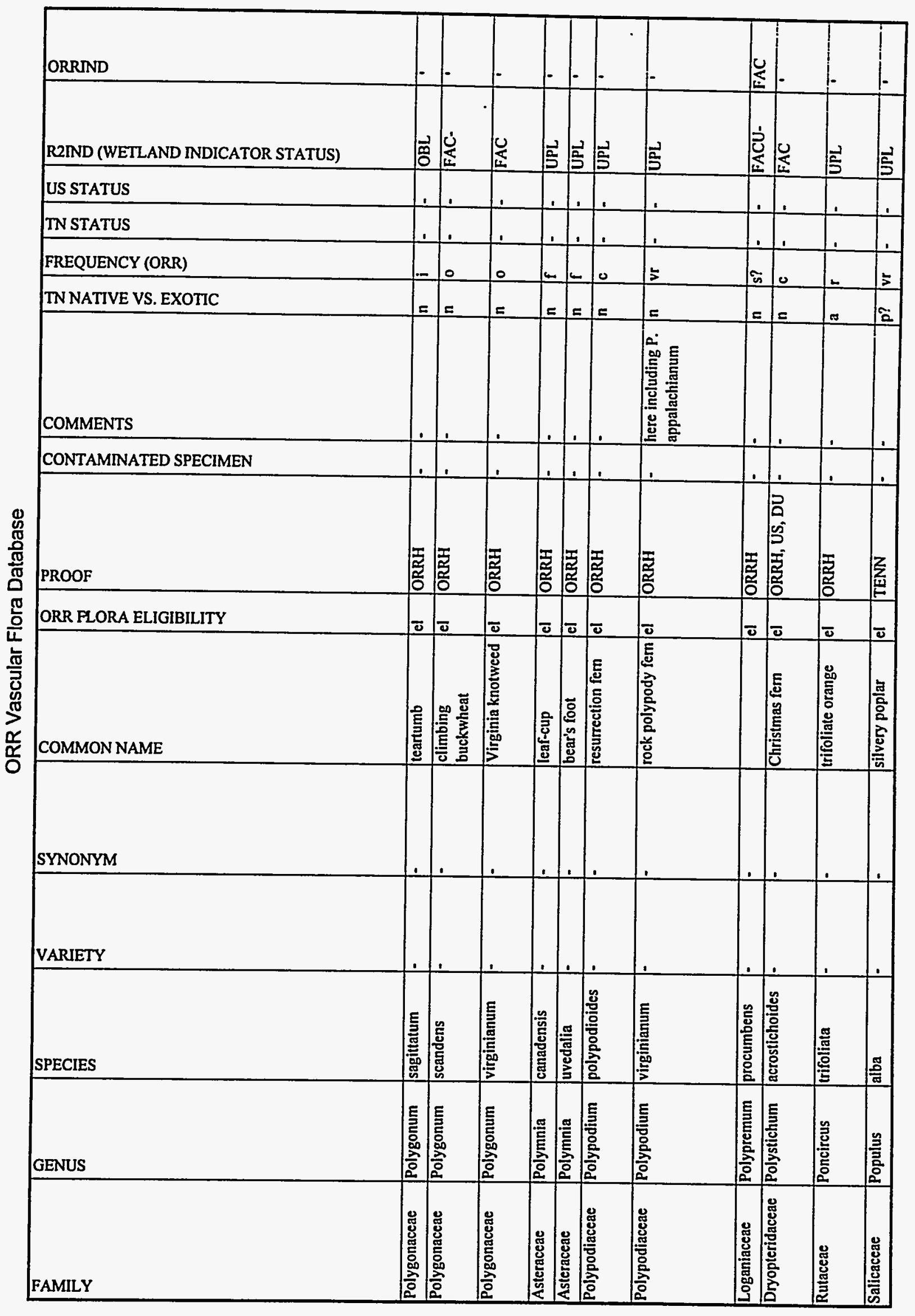




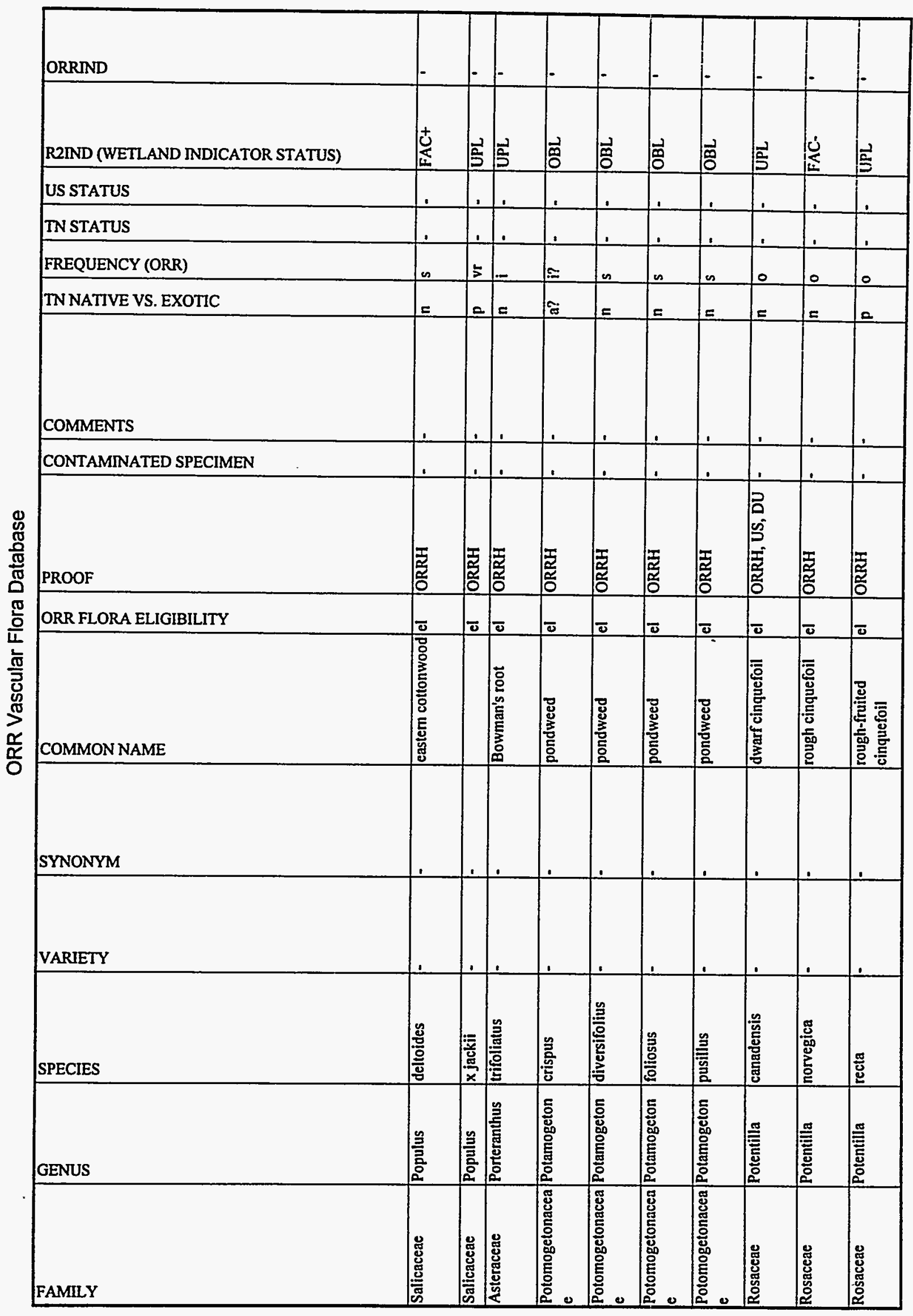


ORR Vascular Flora Database

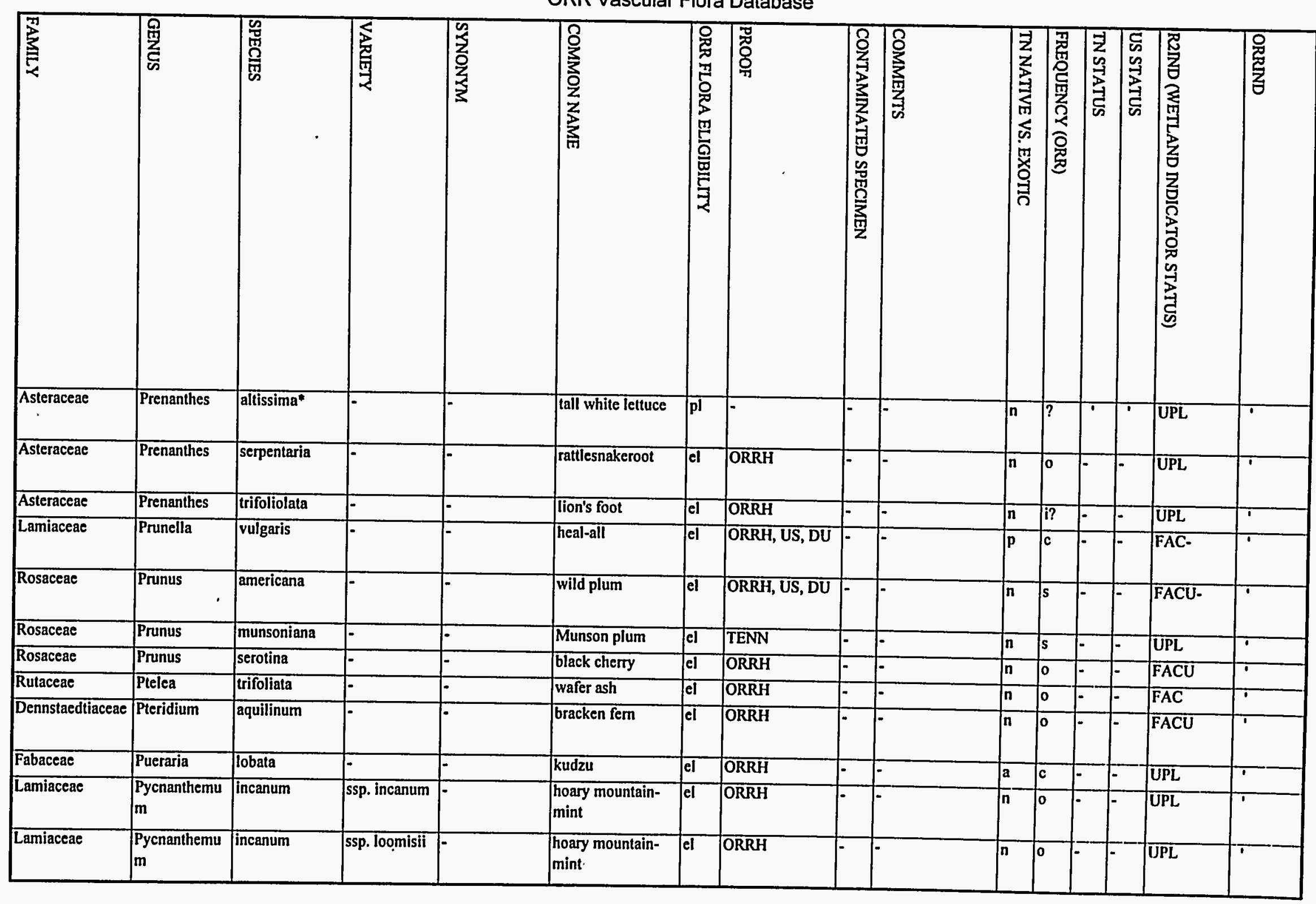




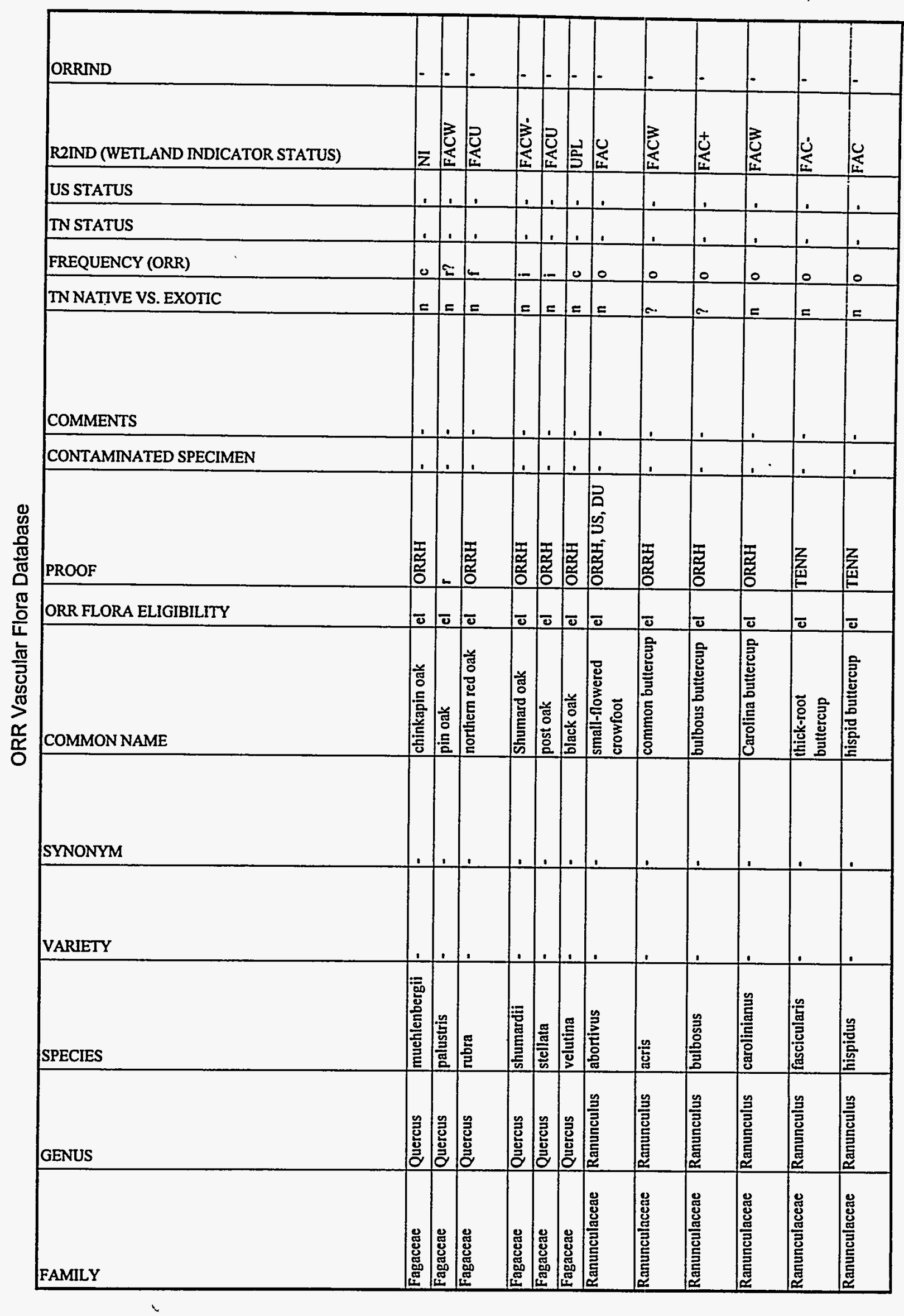




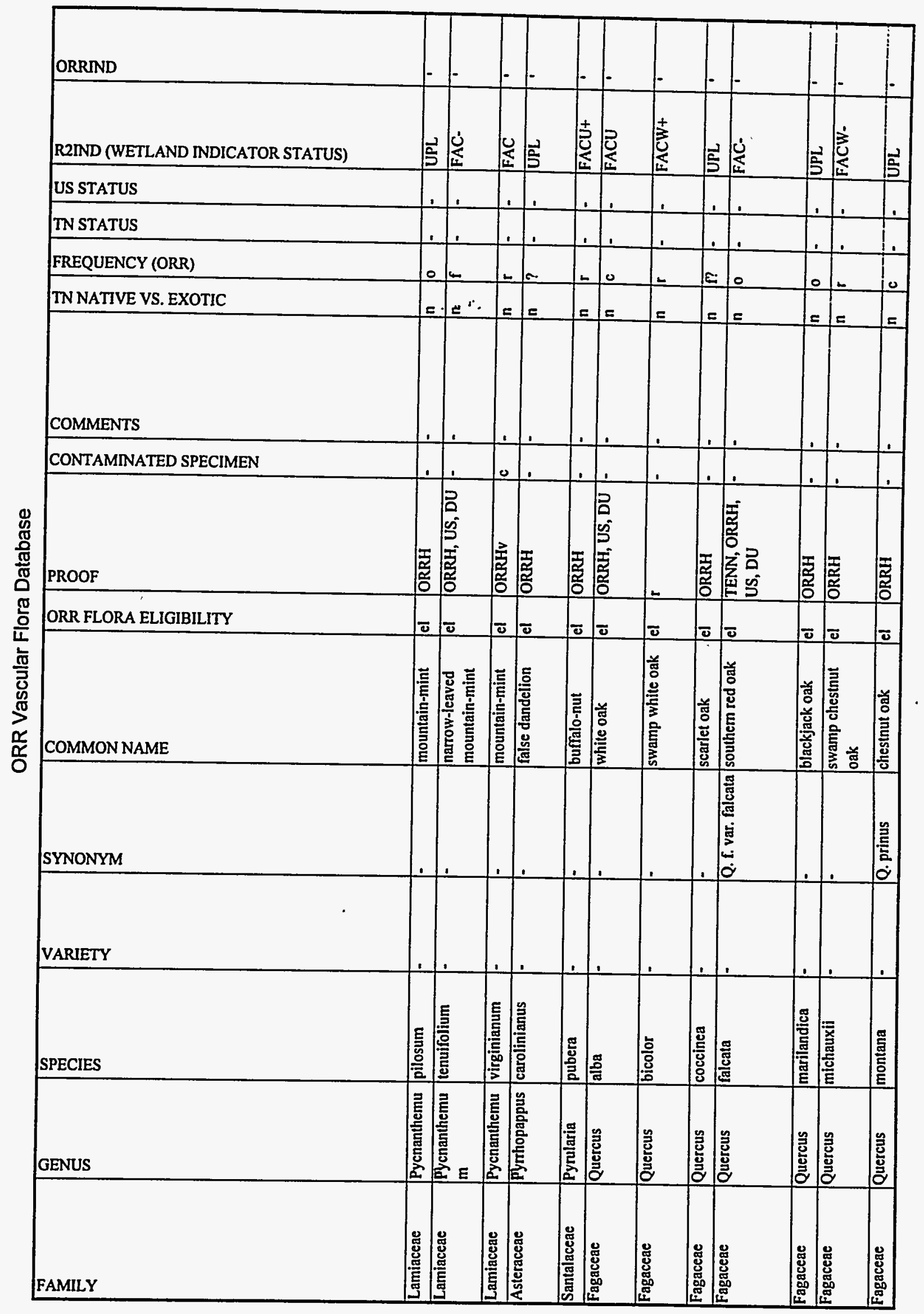




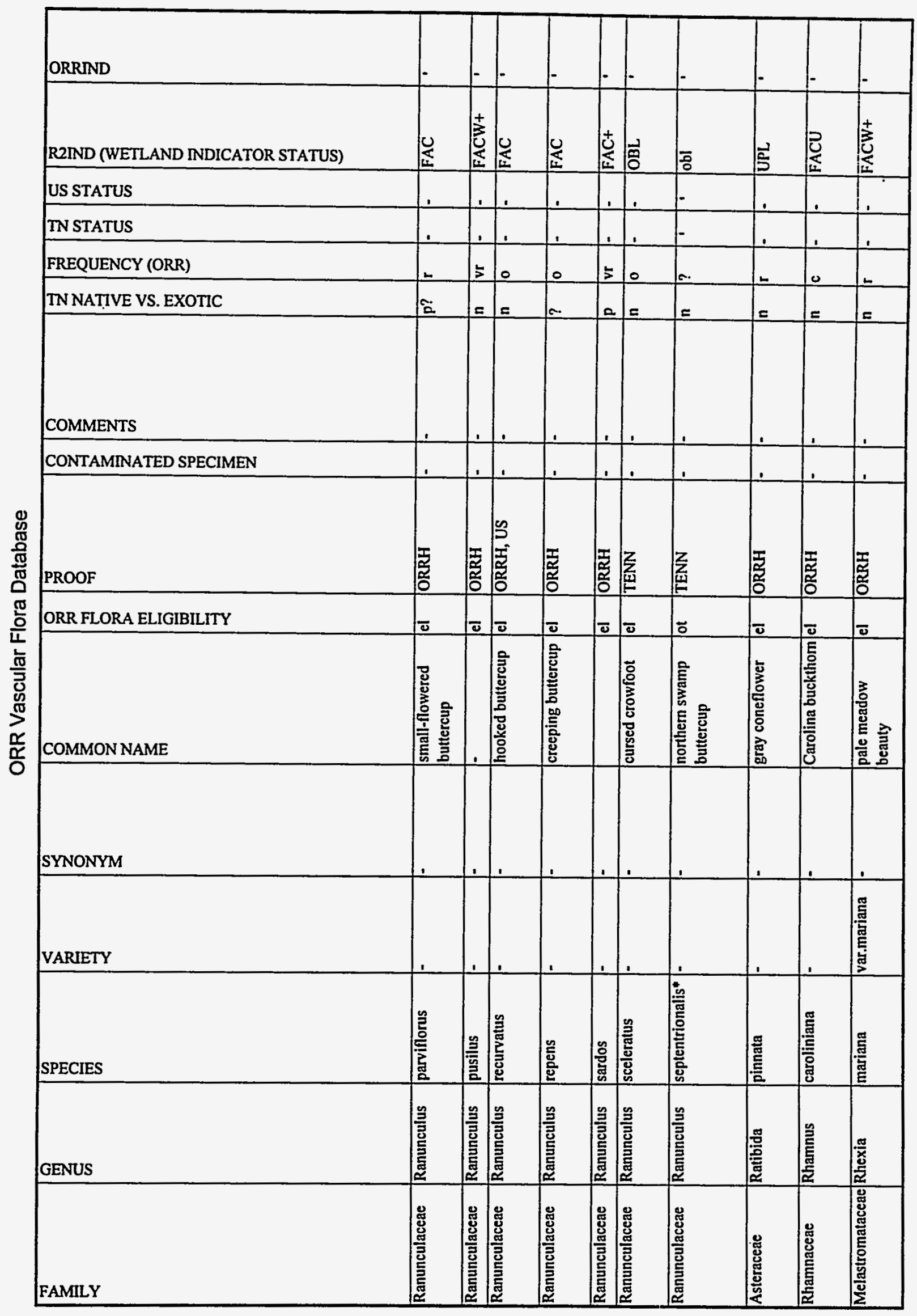




\section{C-101}

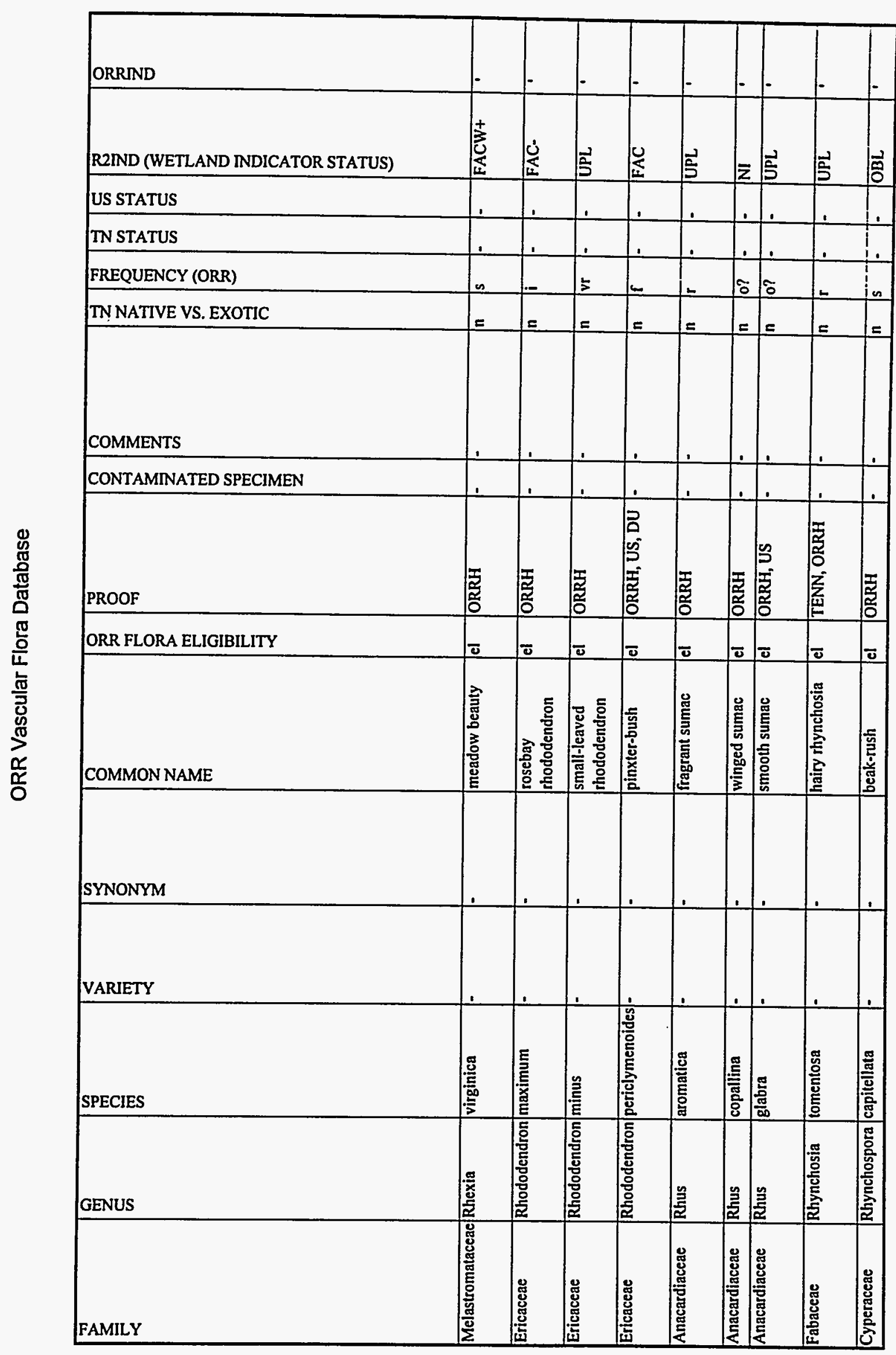




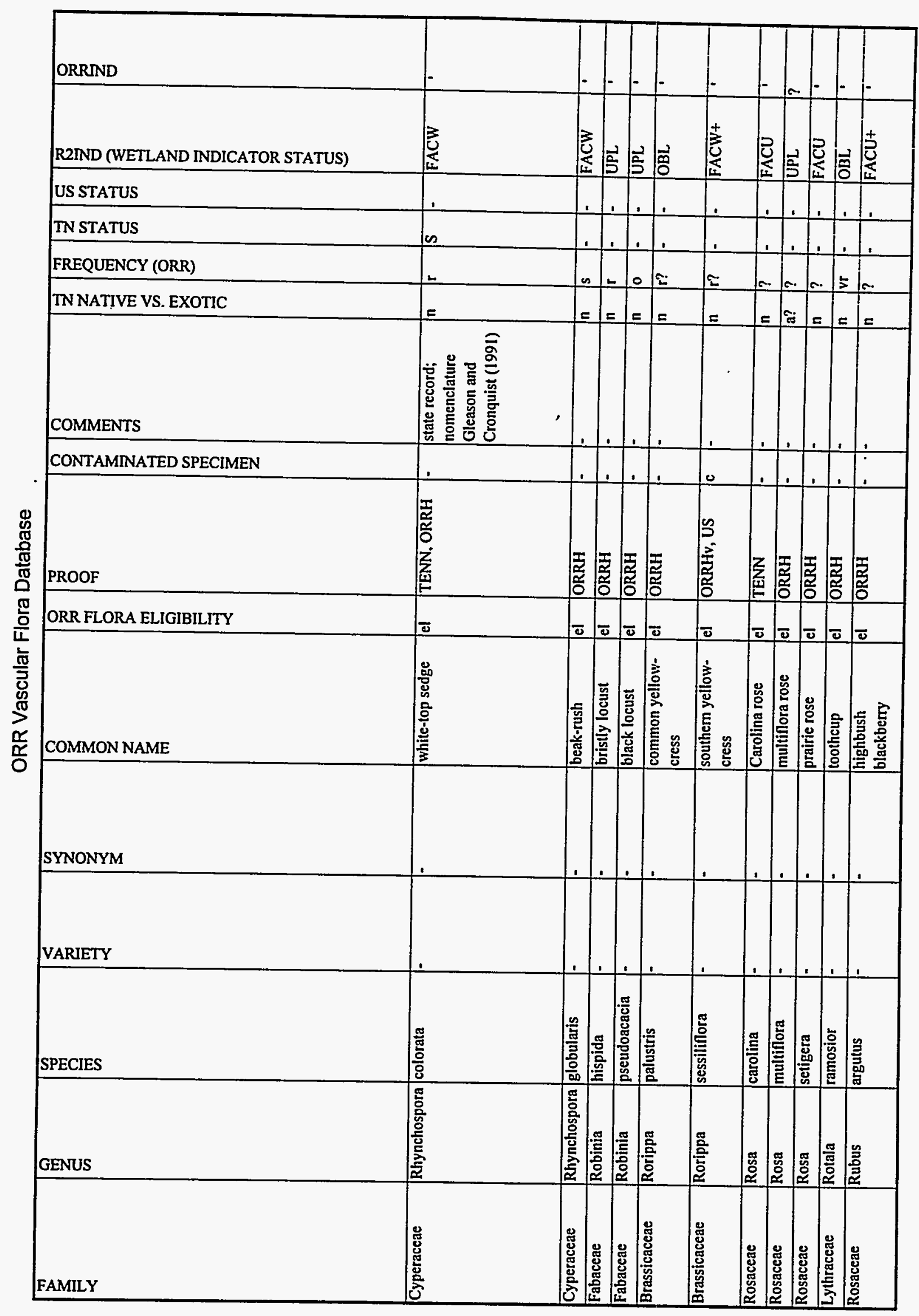




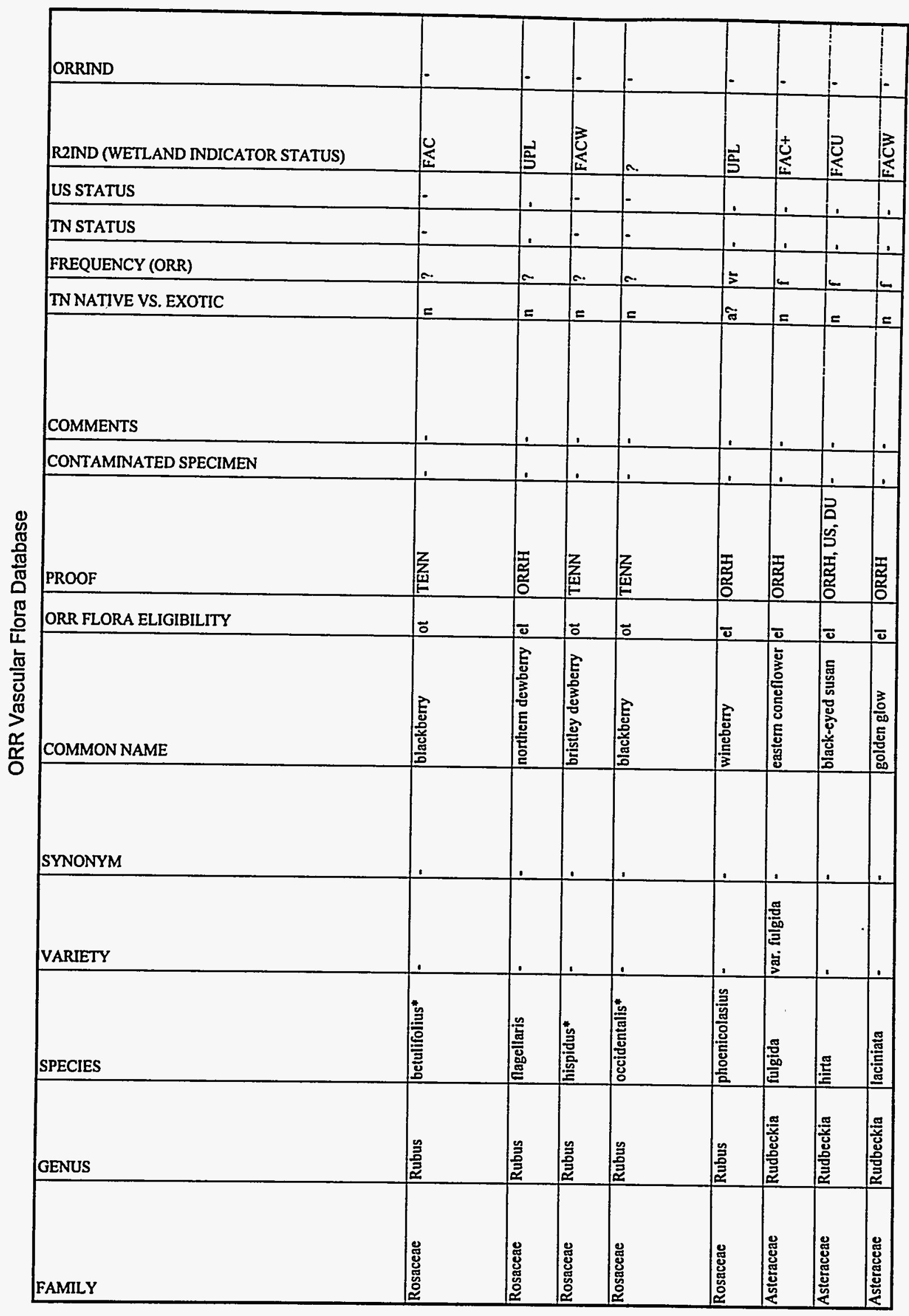




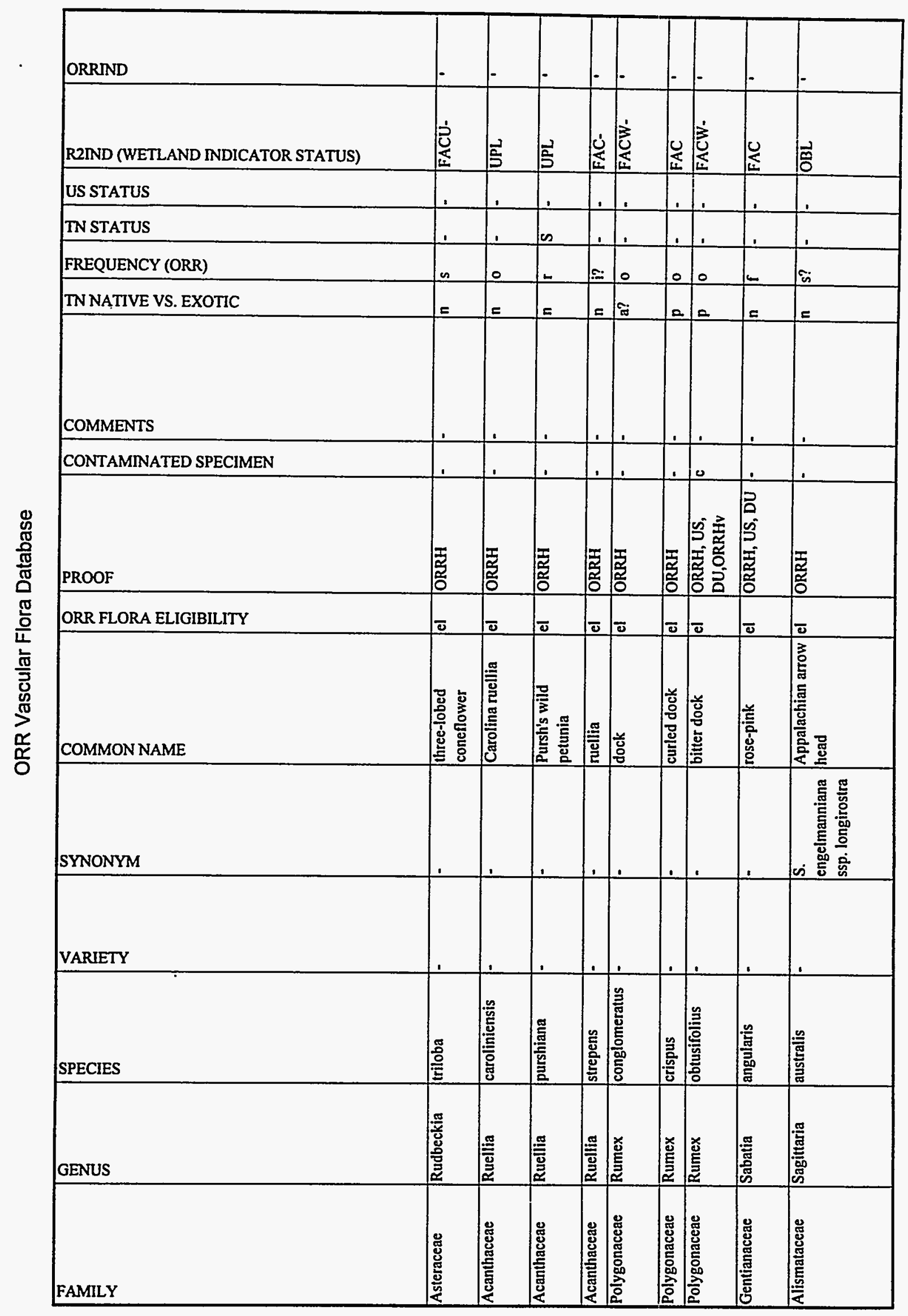




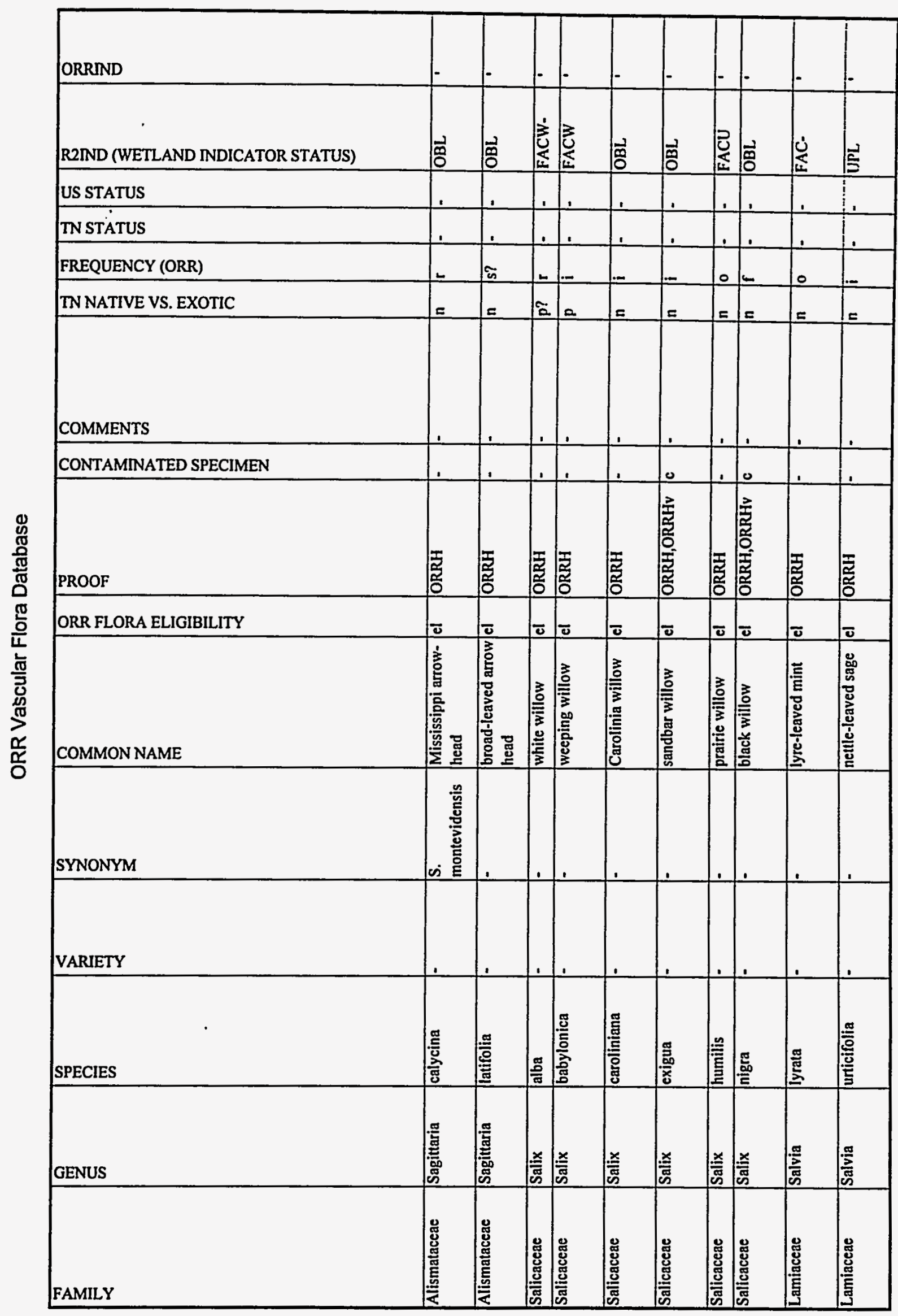




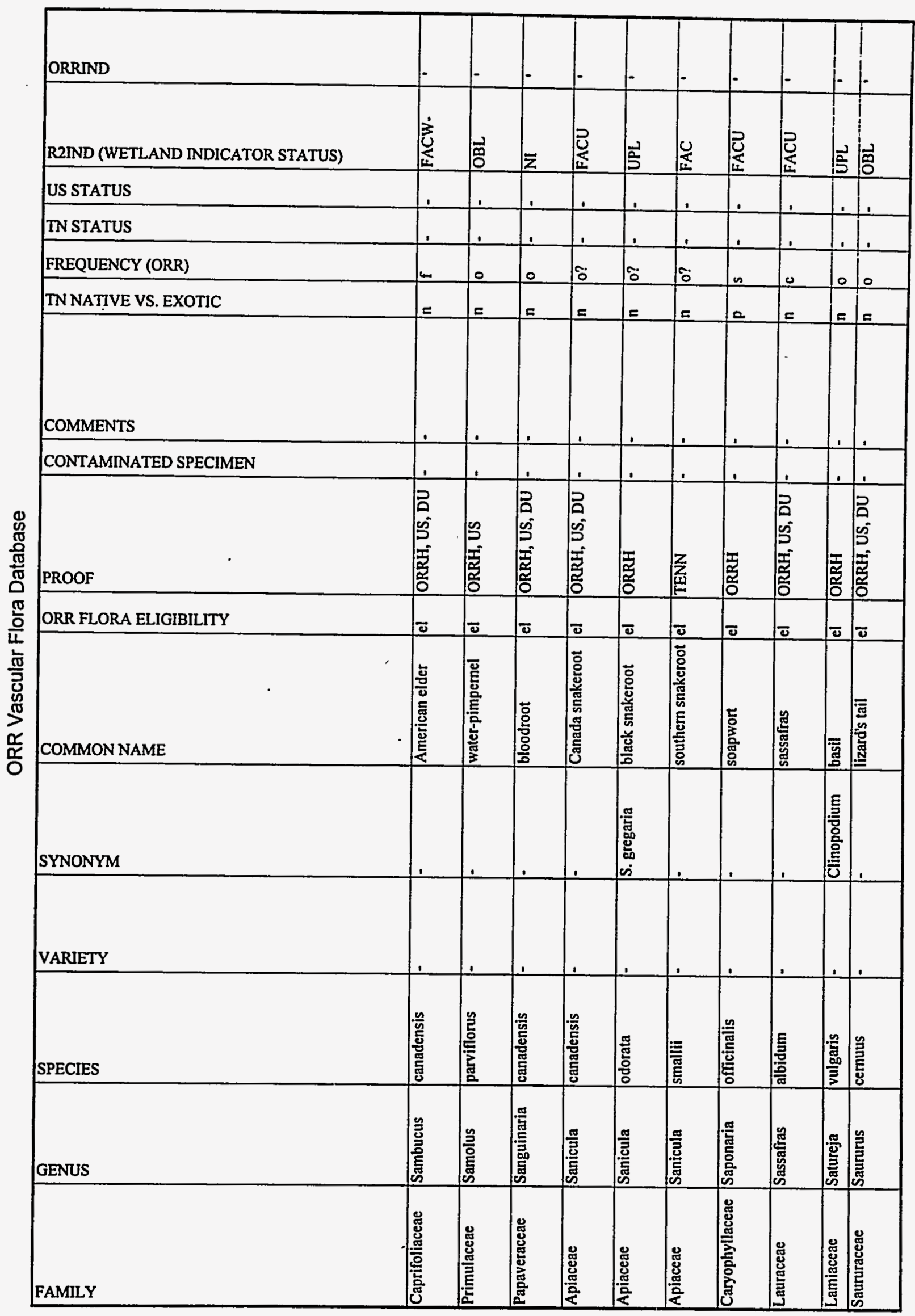




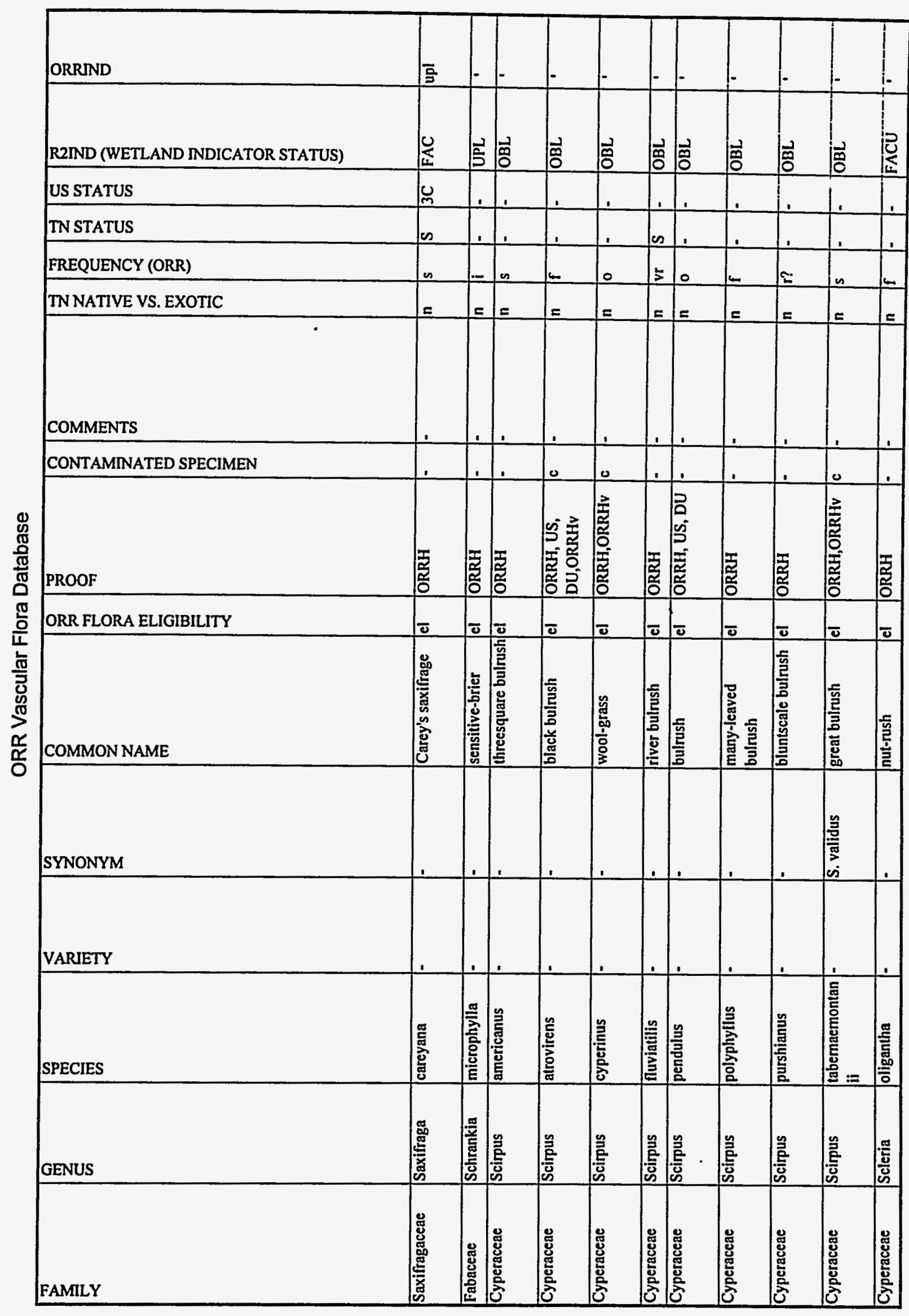




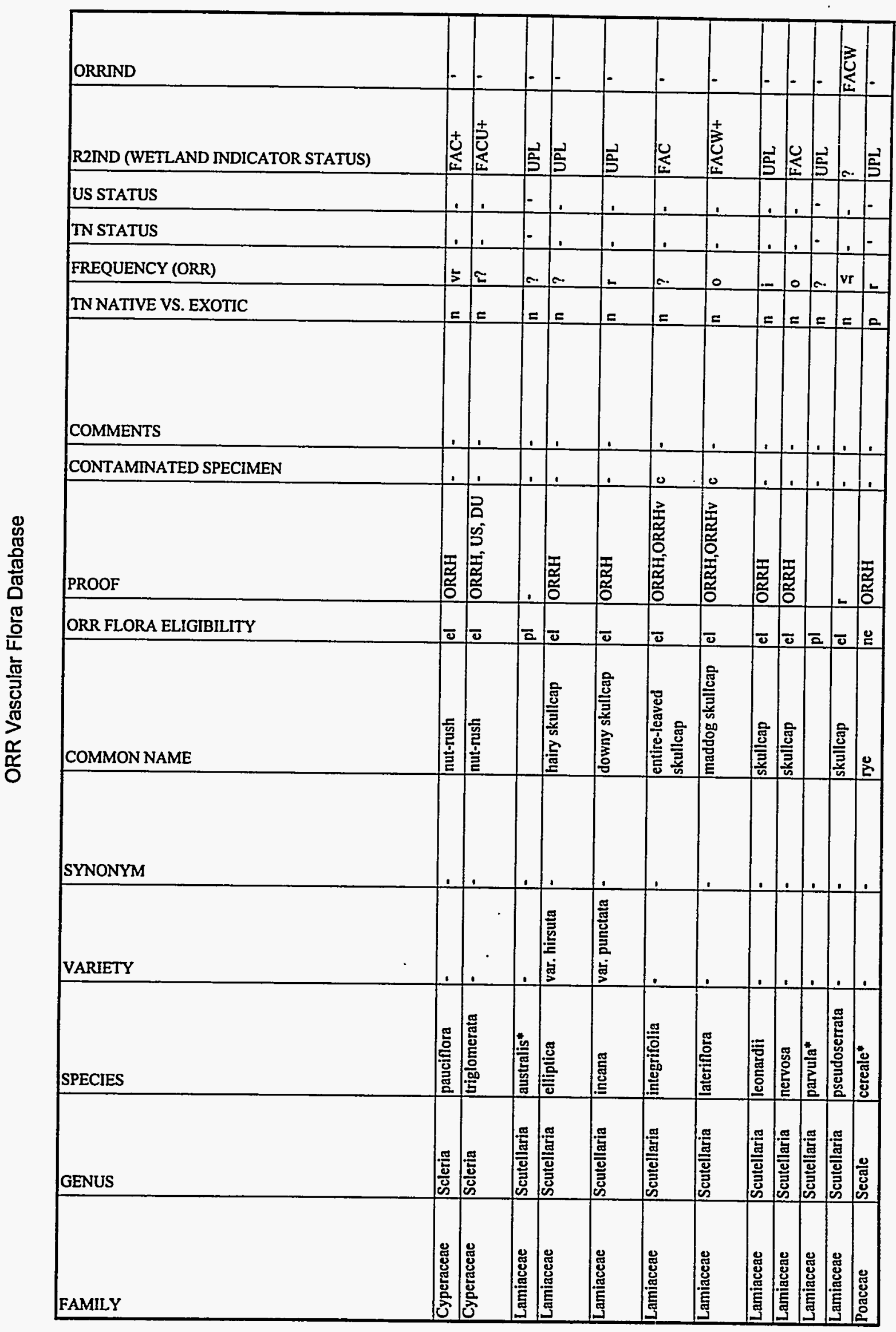




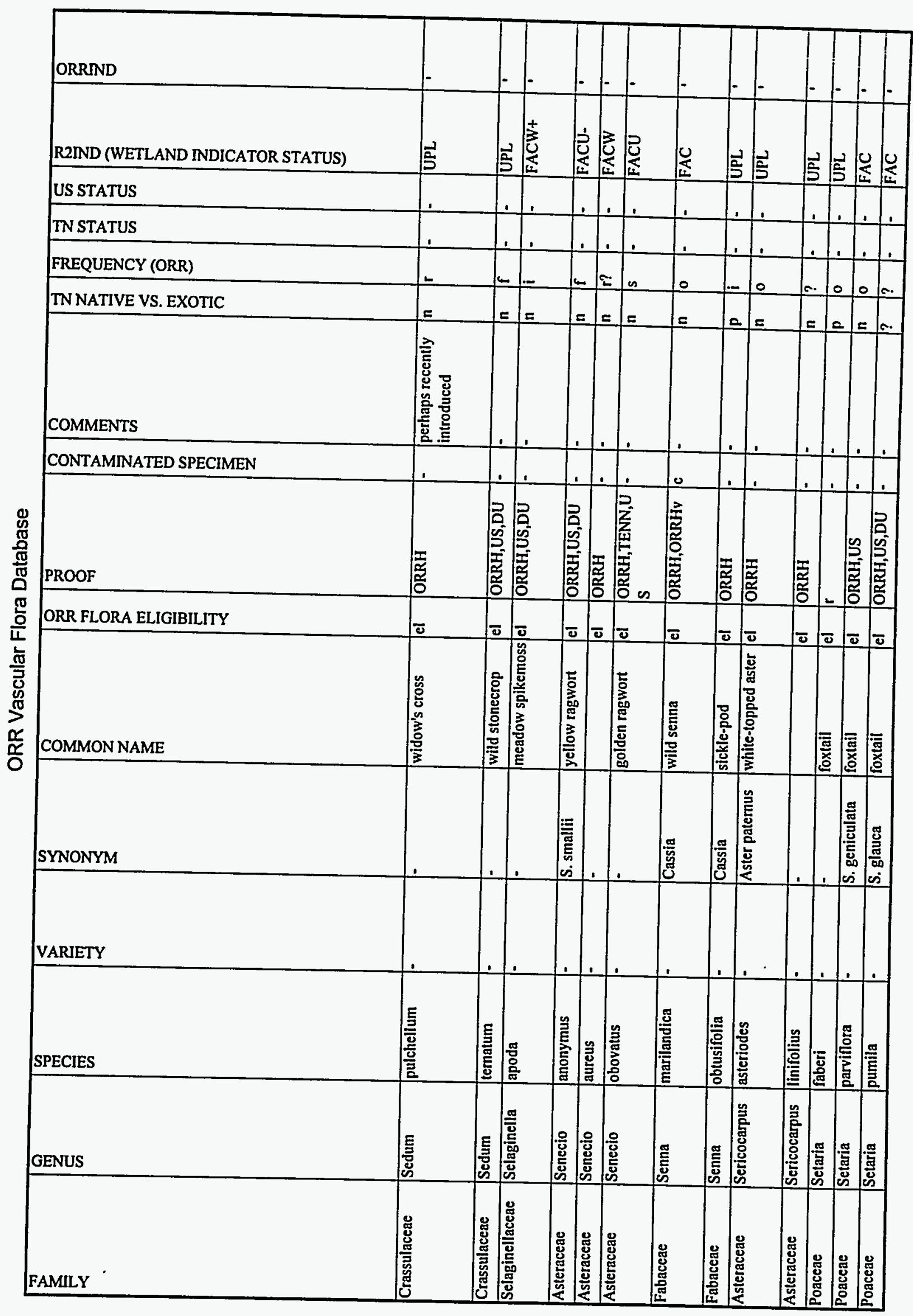




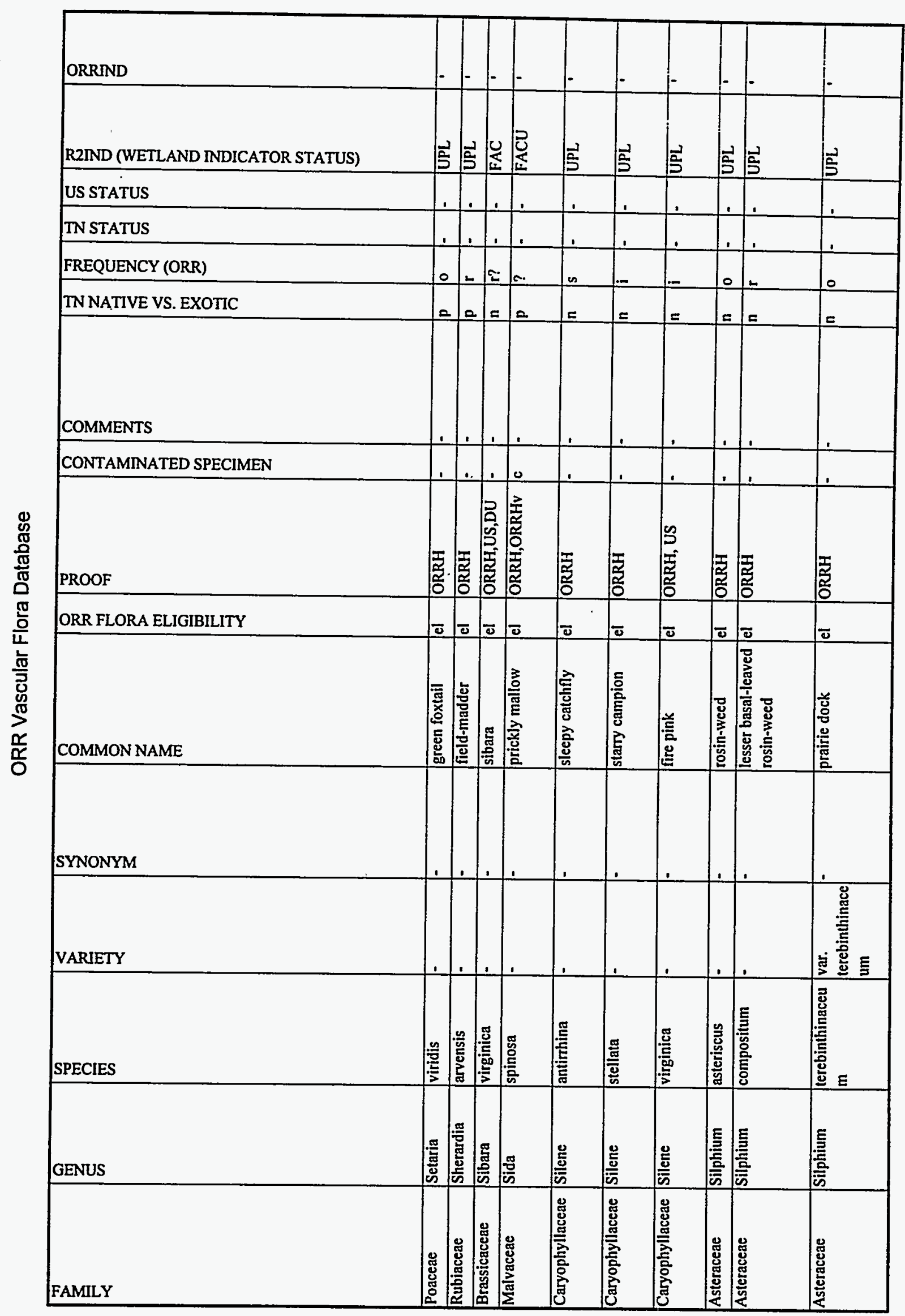




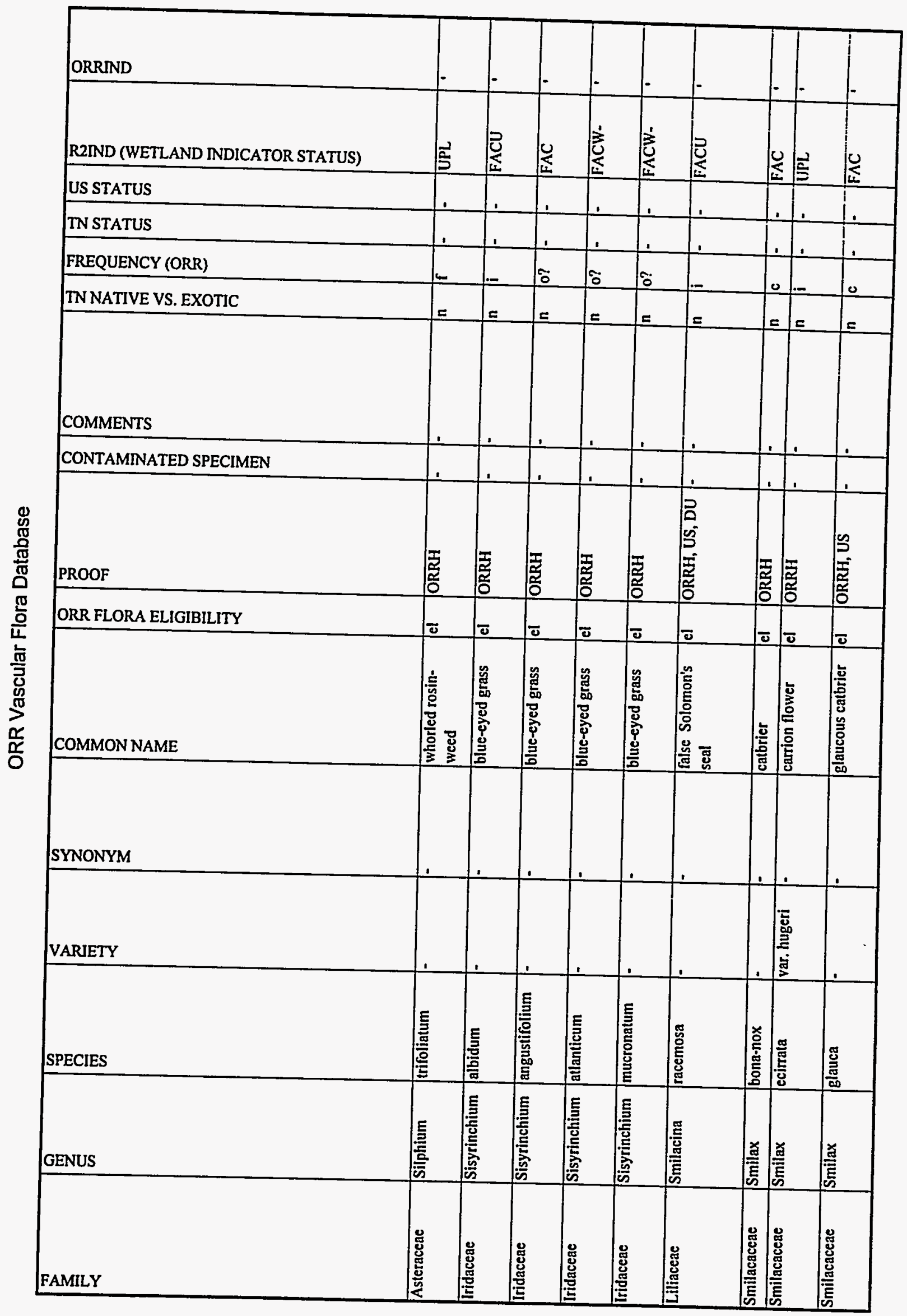




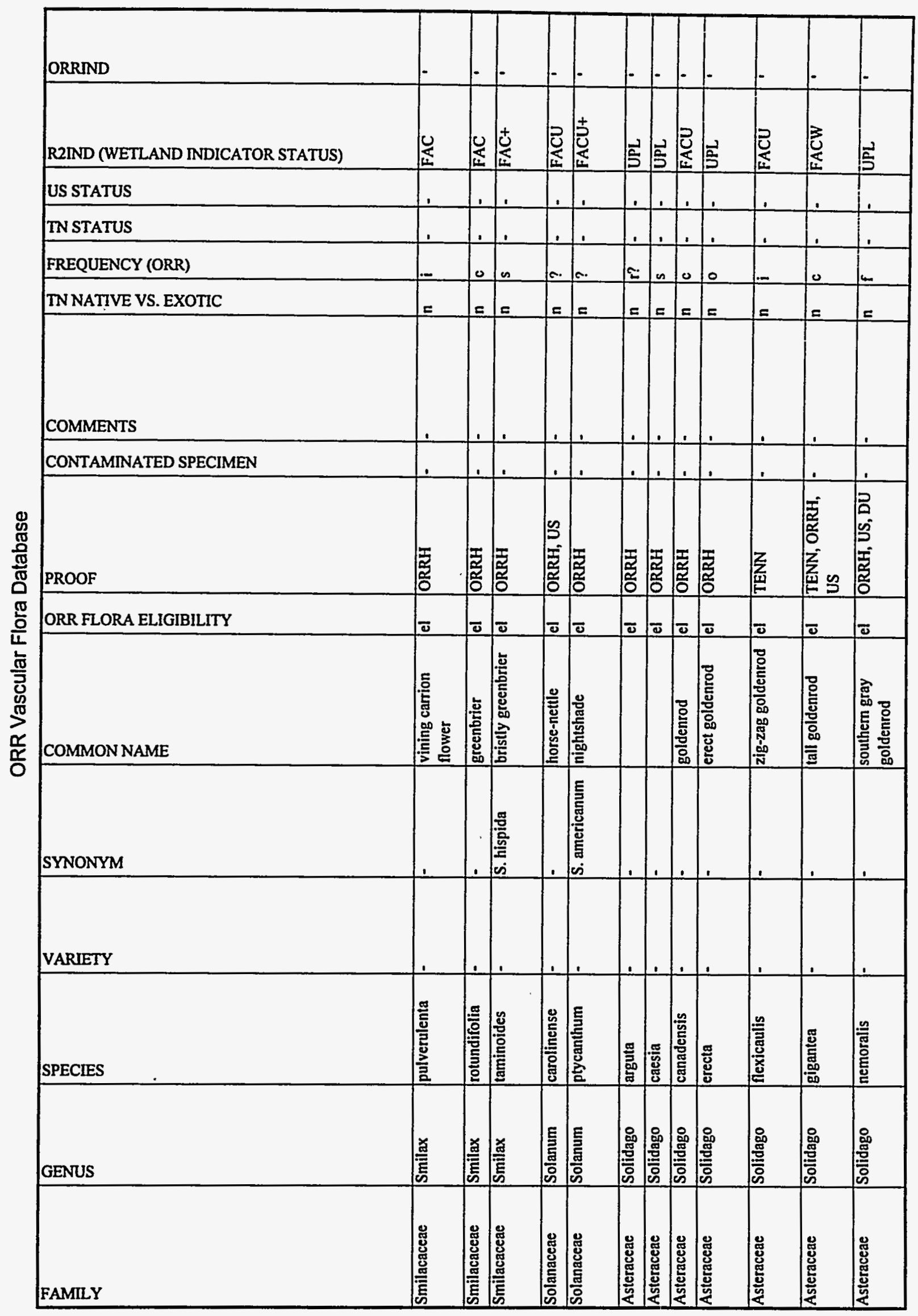




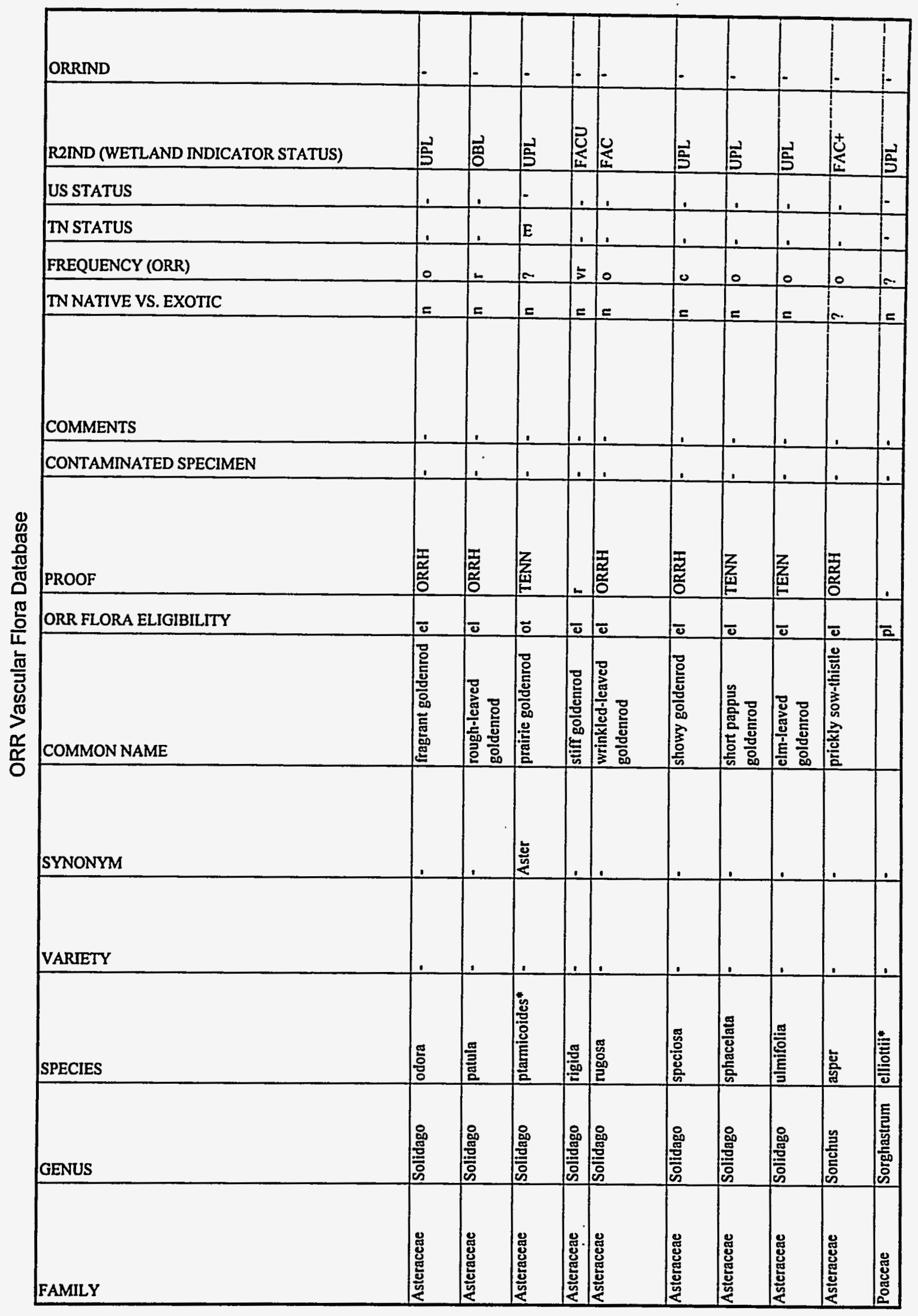




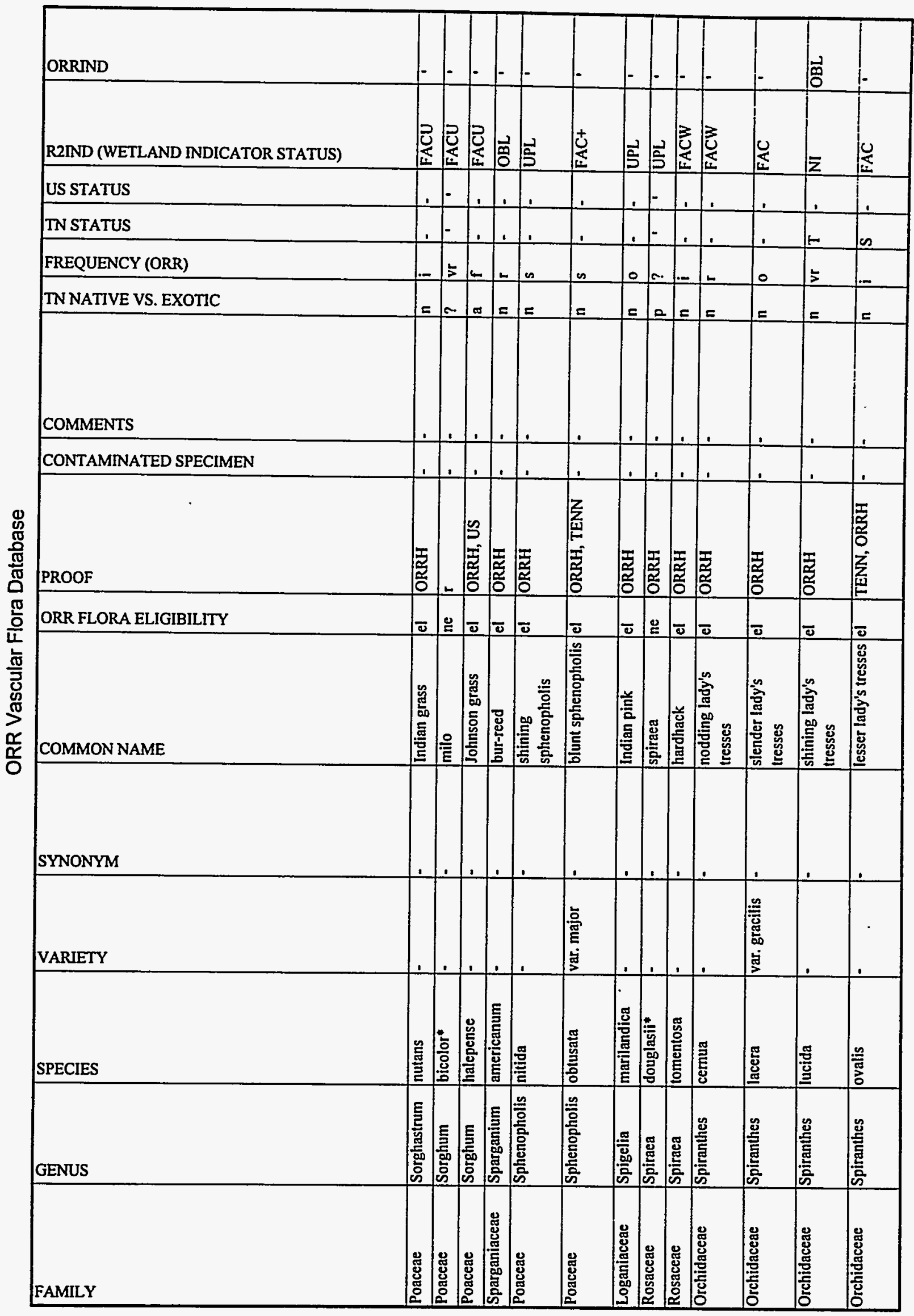




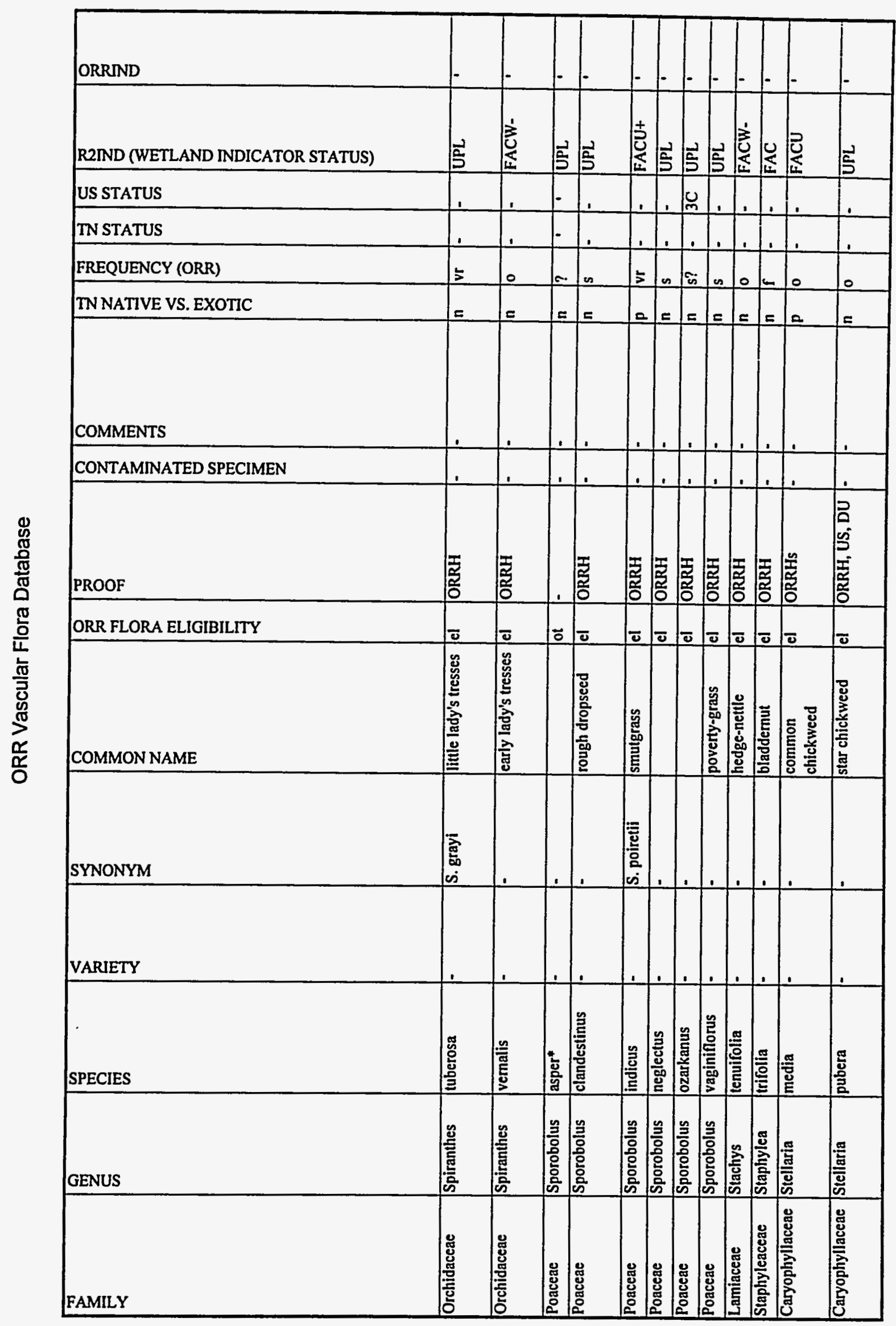




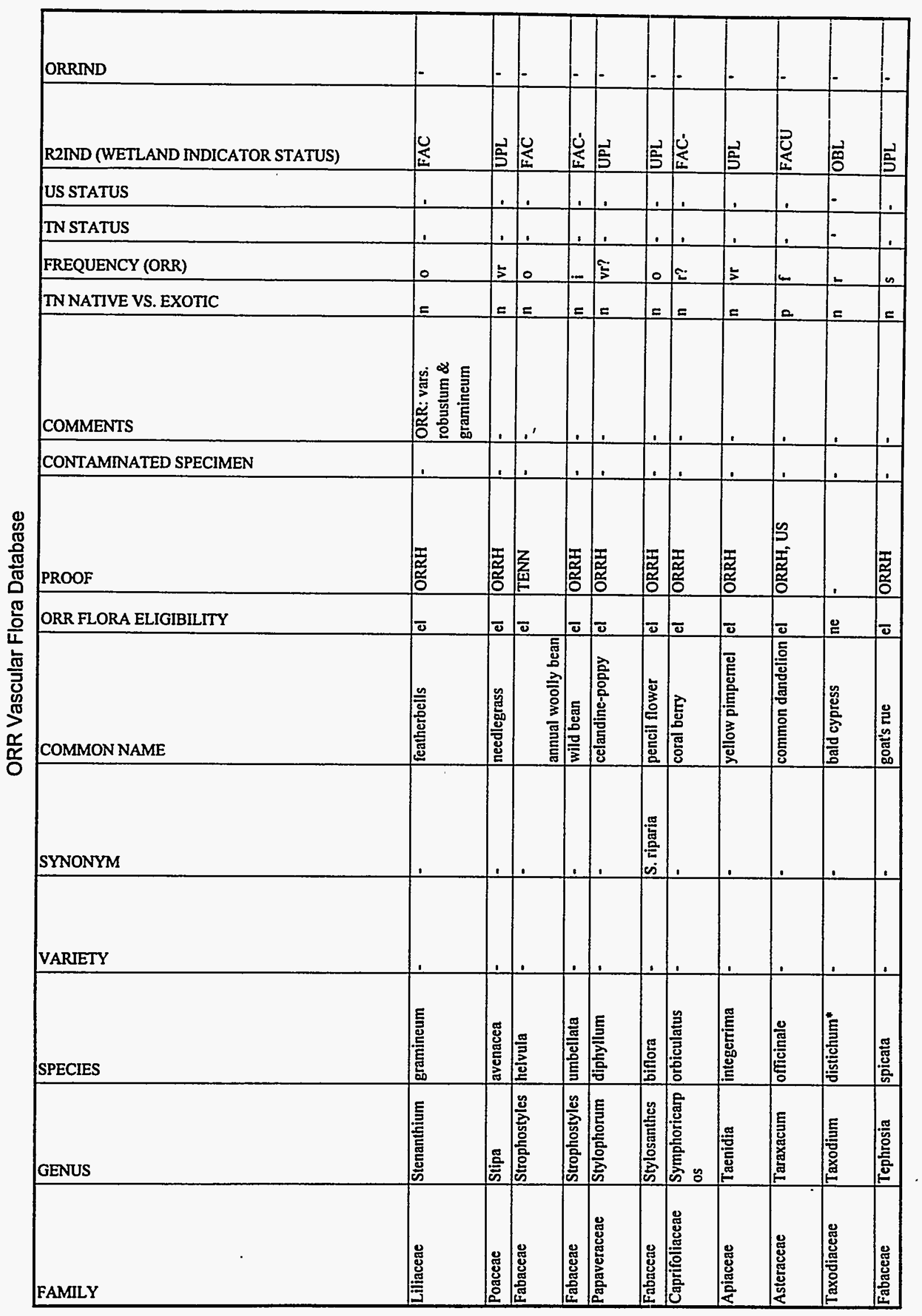




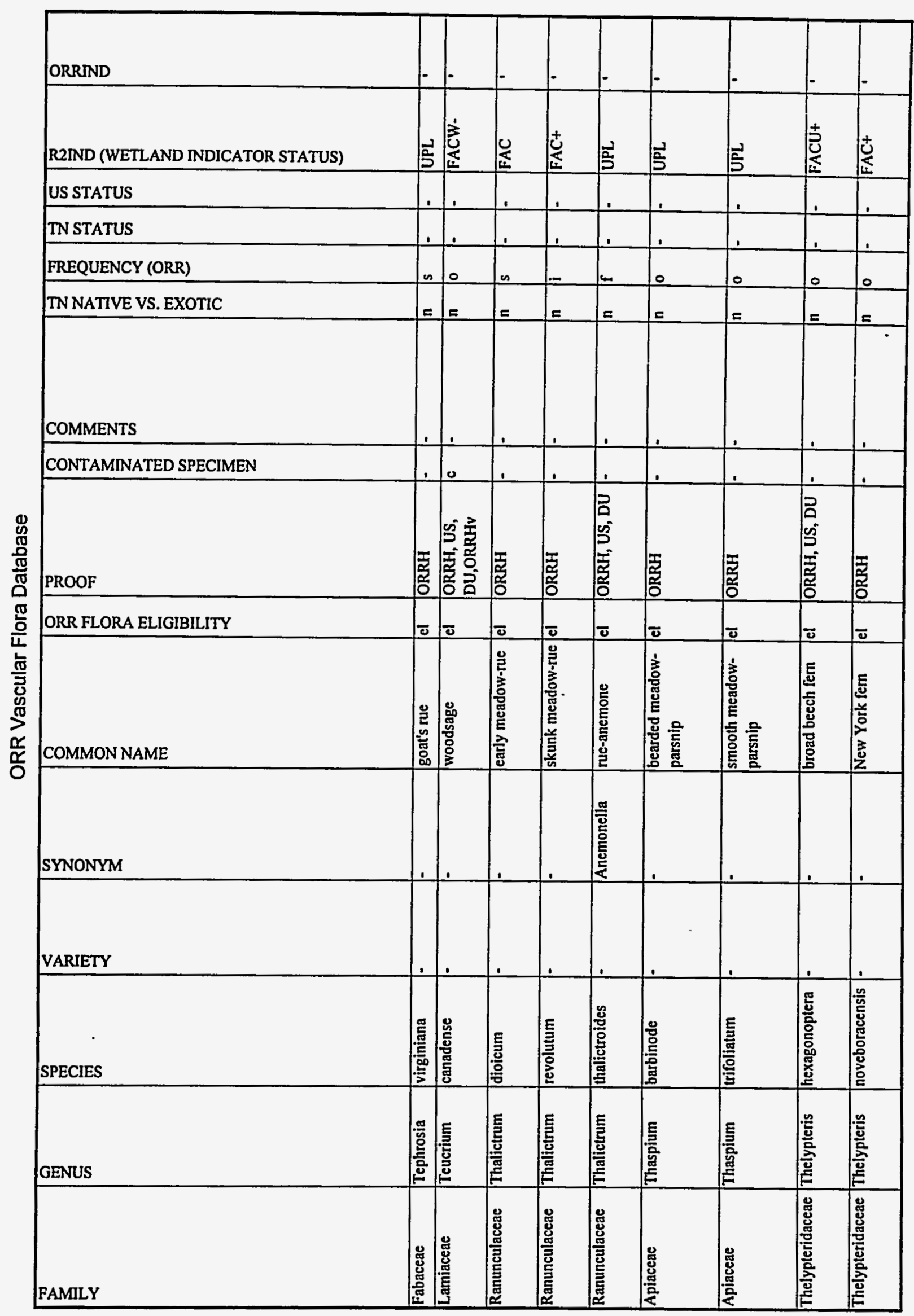




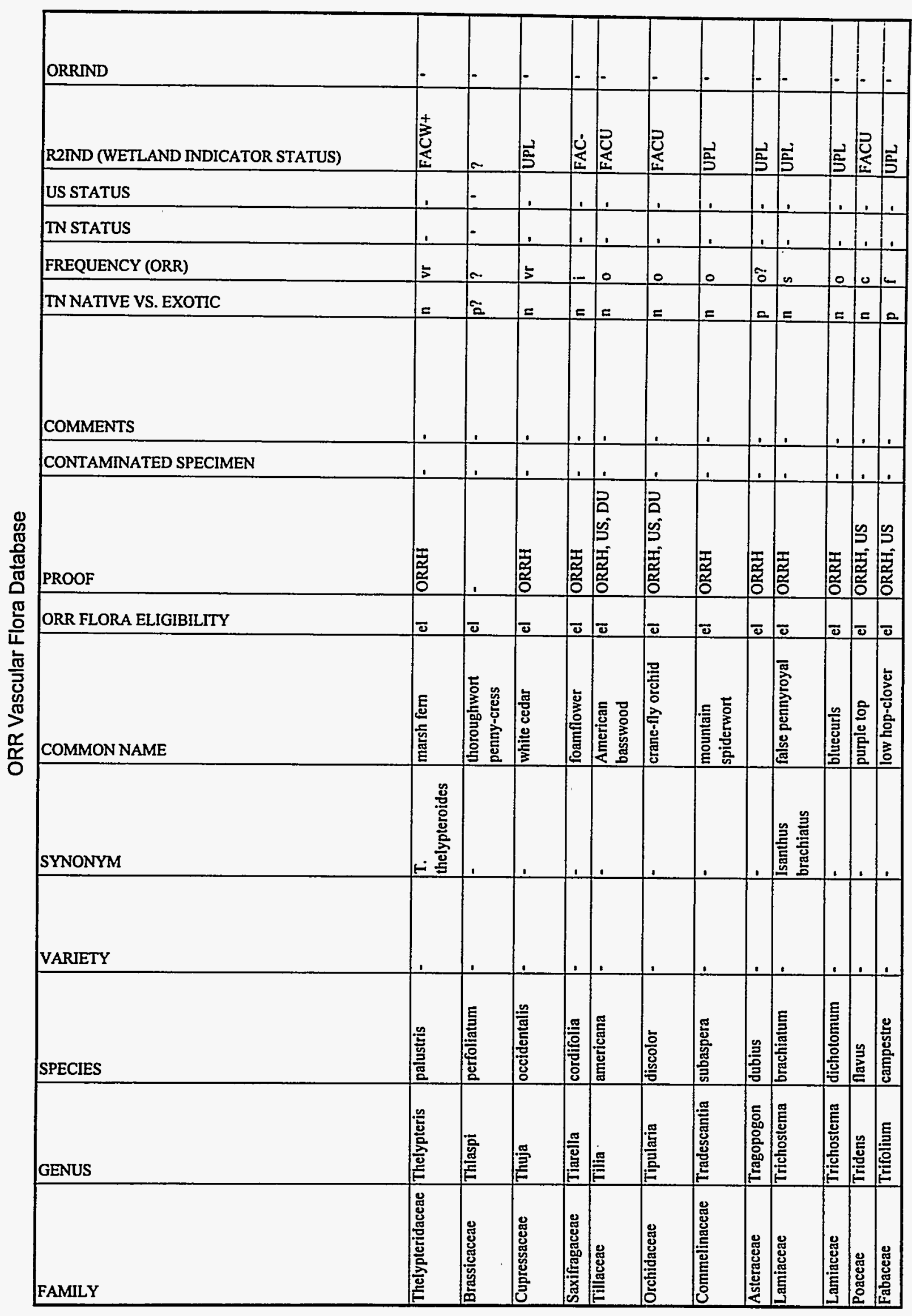




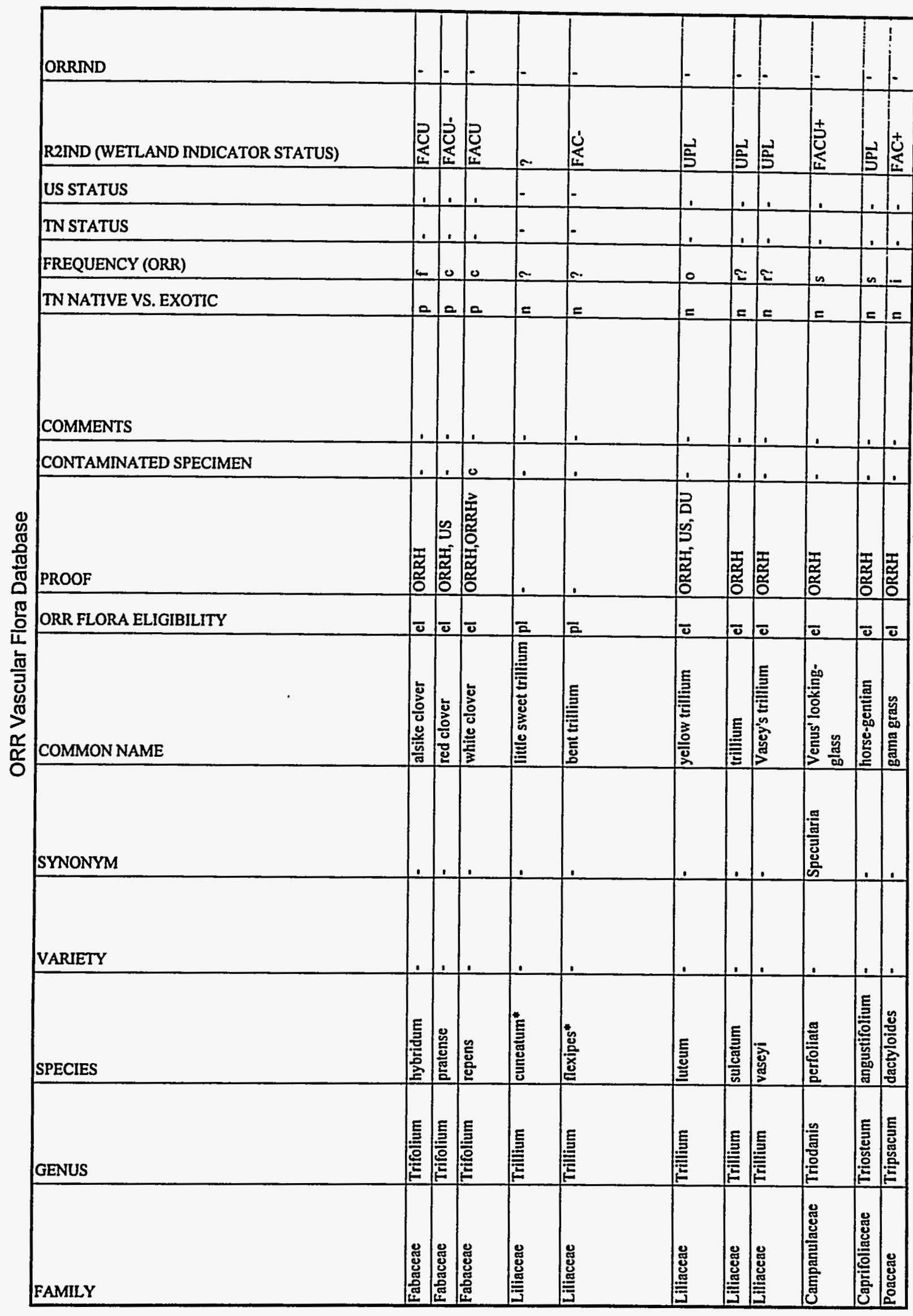




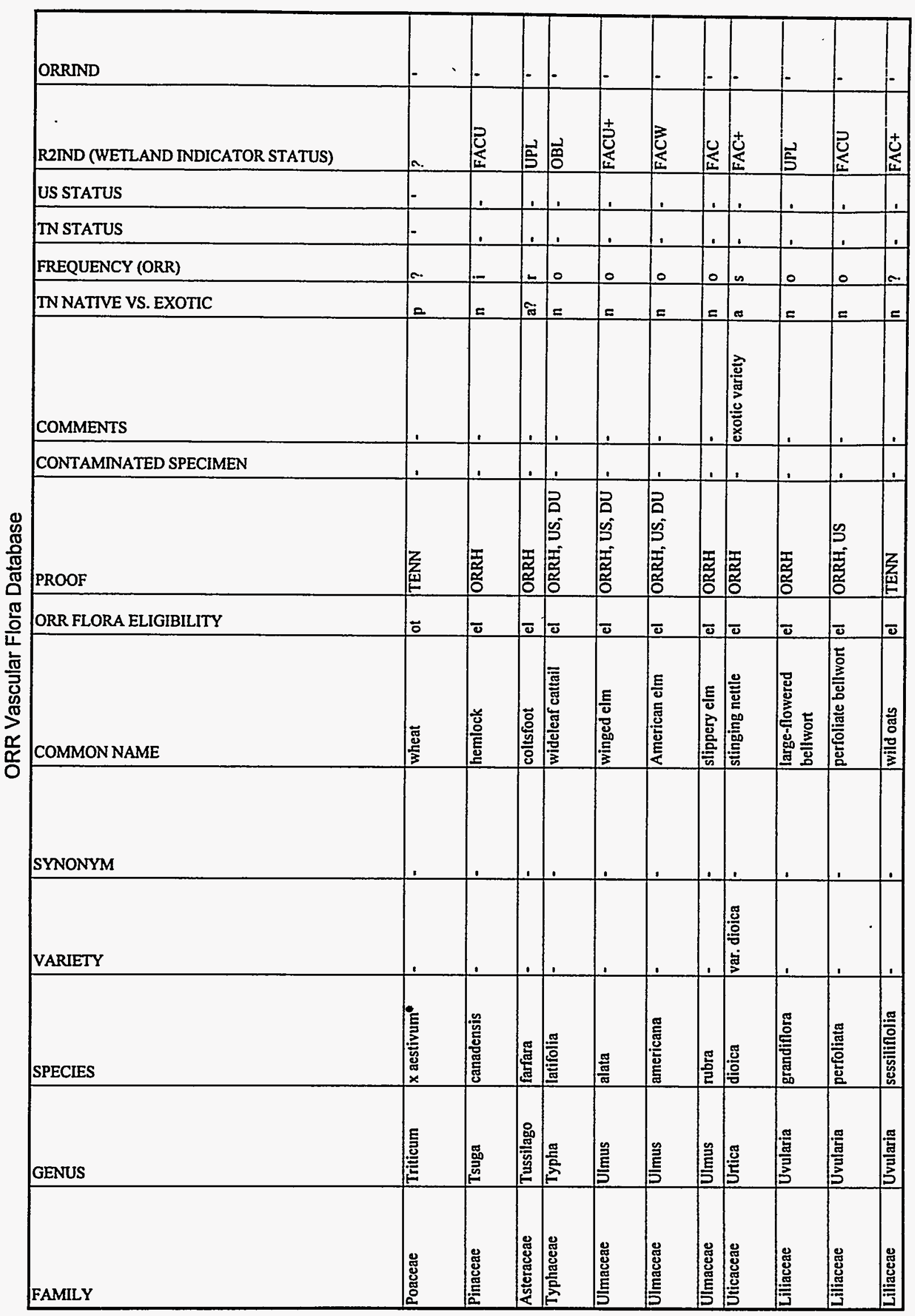




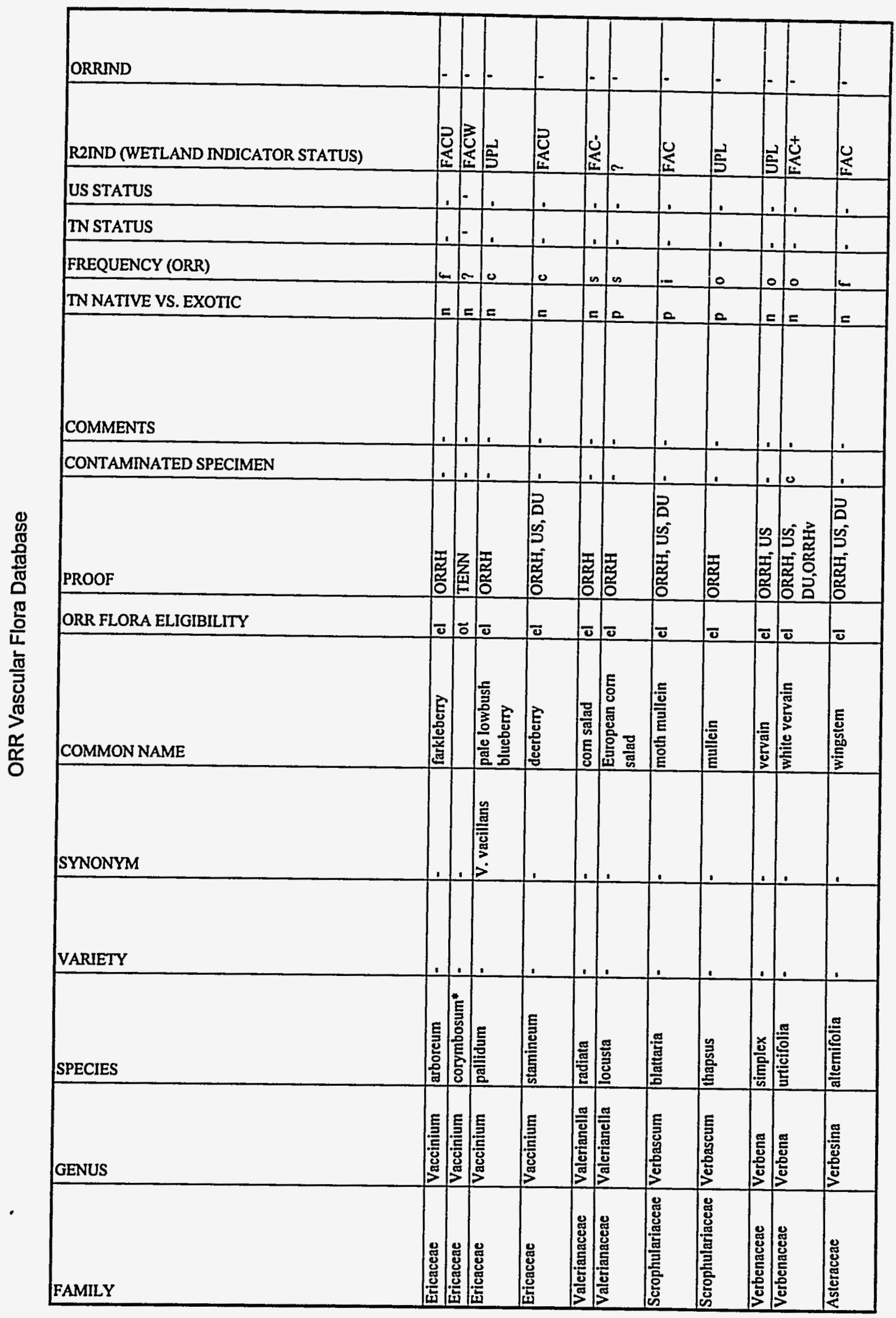




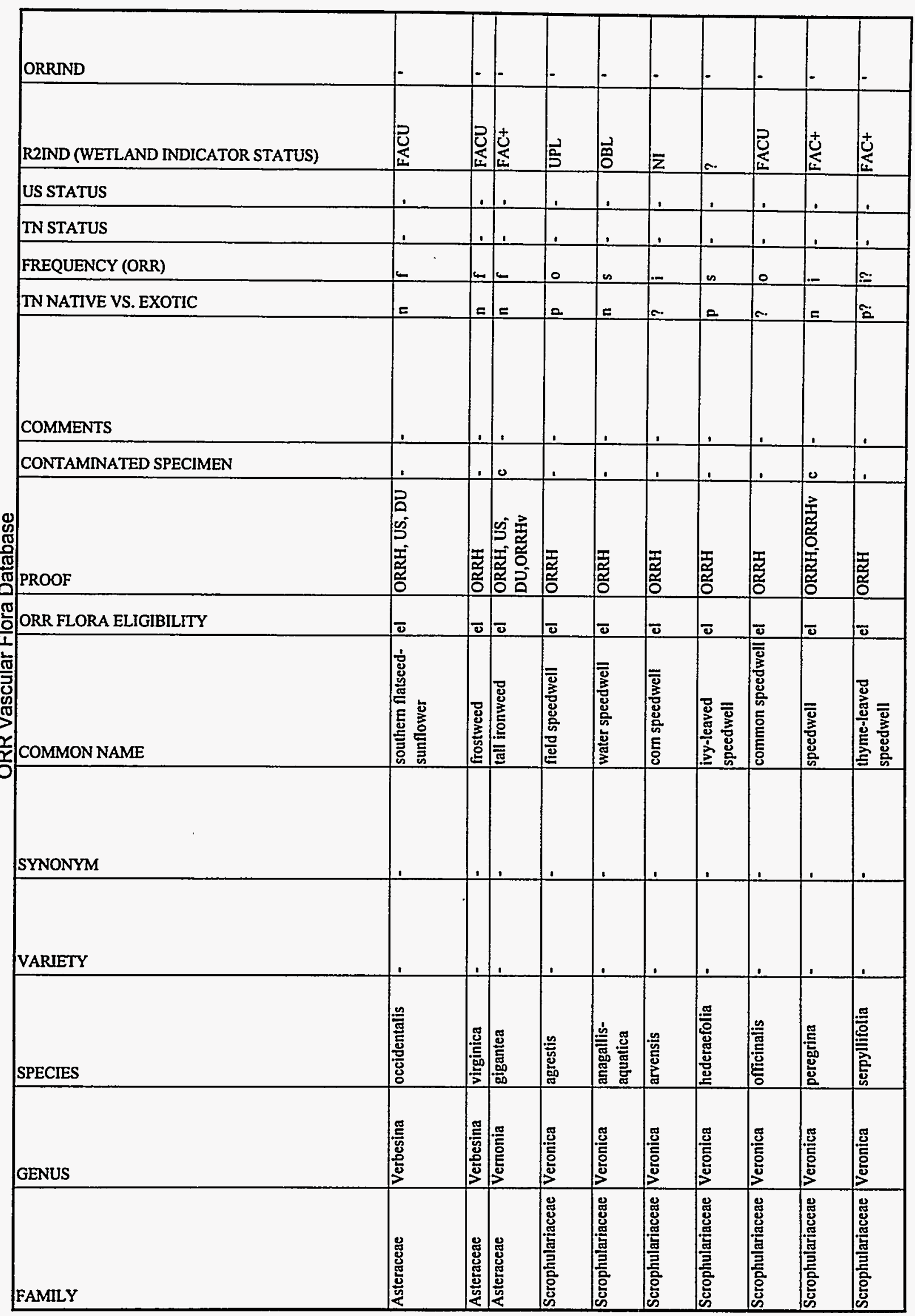




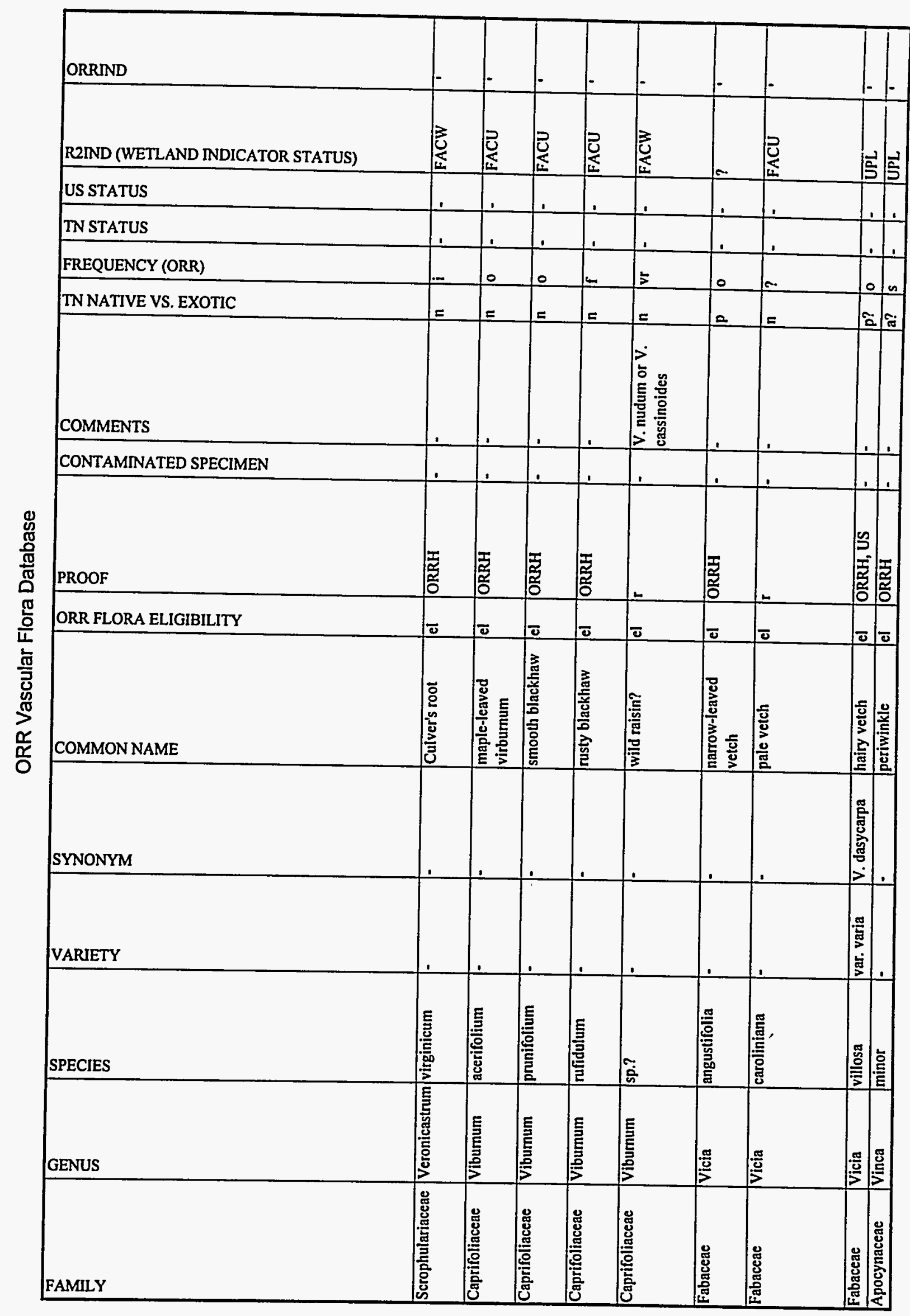




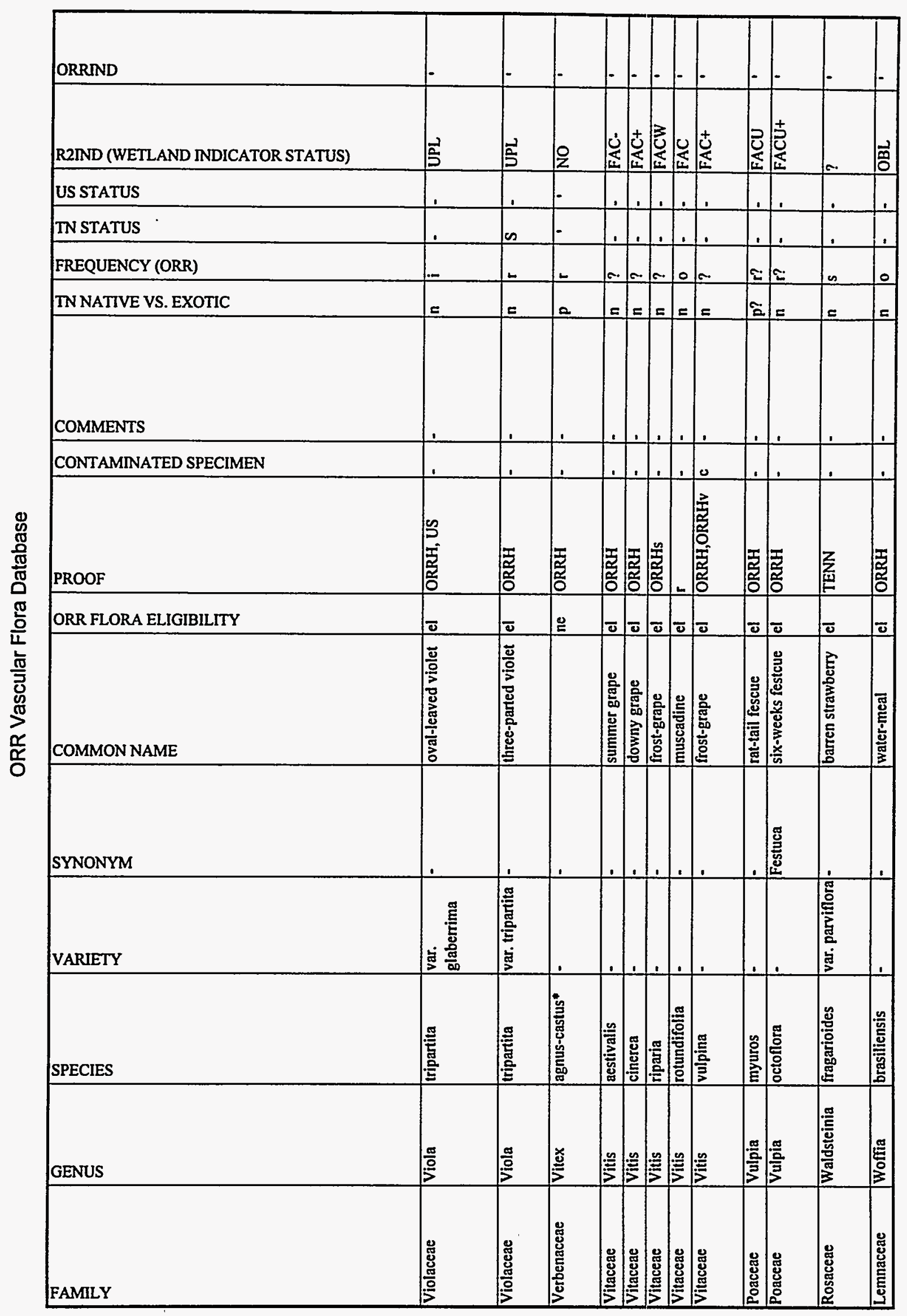




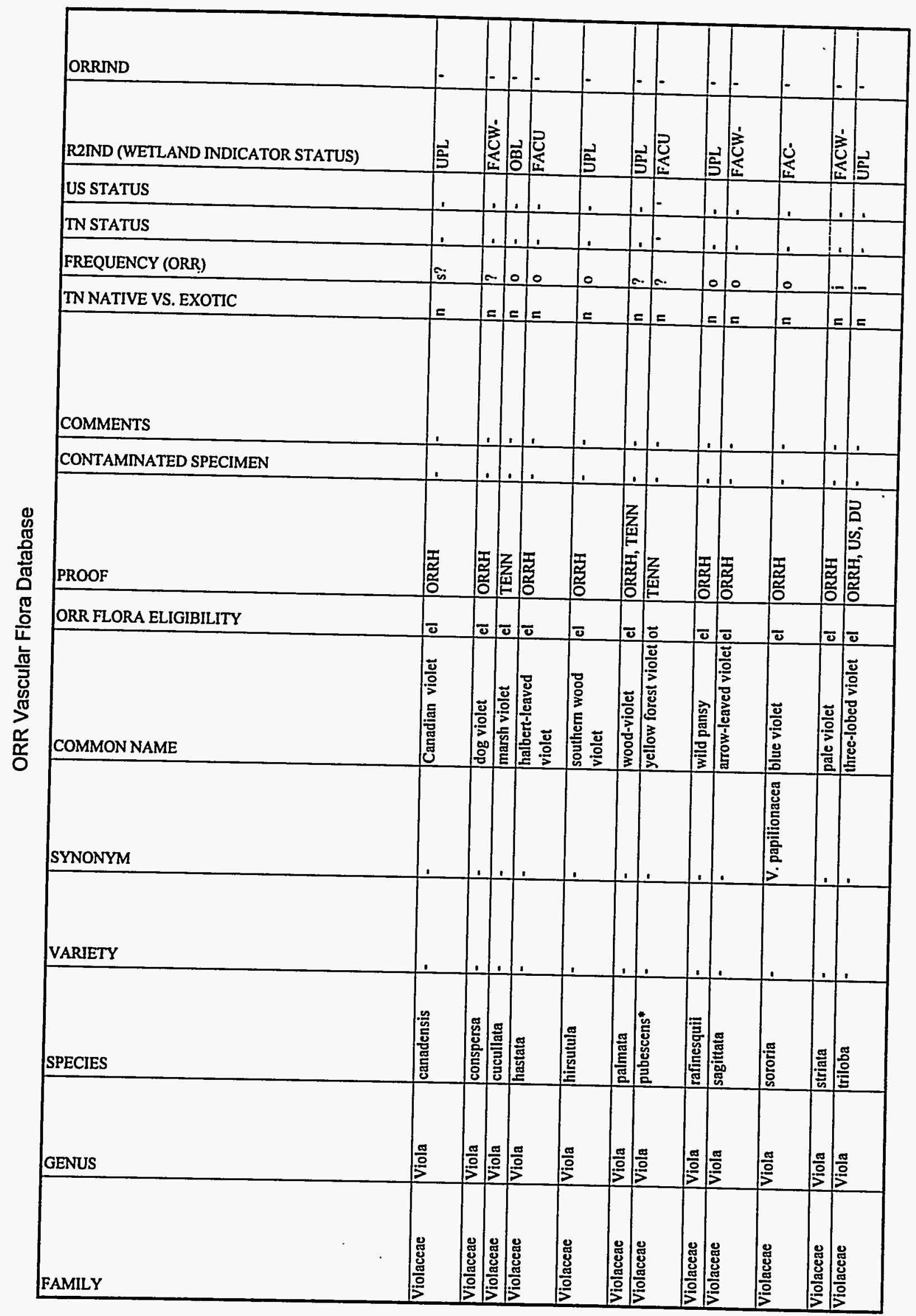




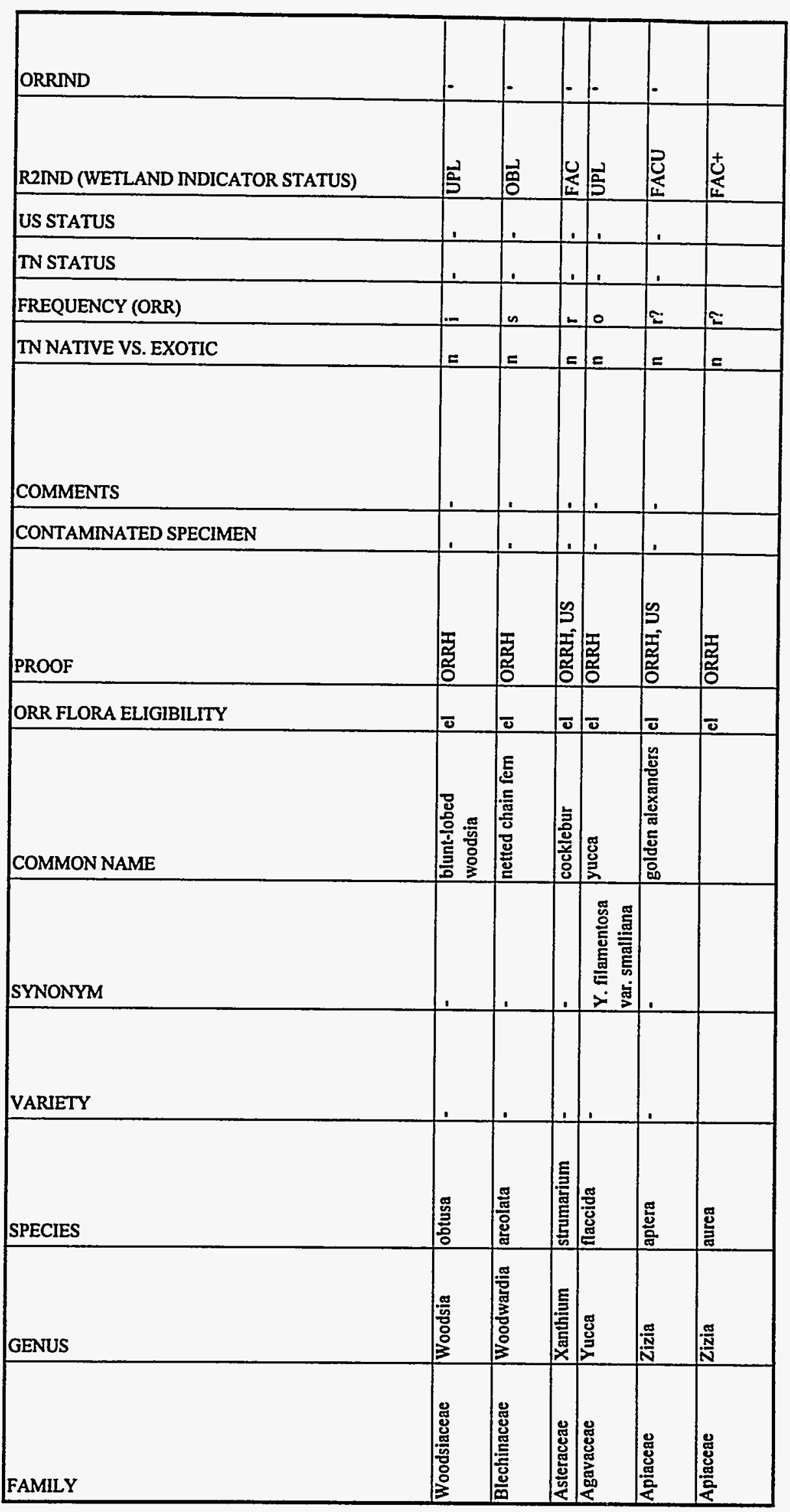




\section{DISTRIBUTION}

ES/ER/TM-194

1. T. L. Ashwood

2. L. V. Asplund

3. H. L. Boston

4. B. A. Bowers (PGDP)

5. H. M. Braunstein

6. V. J. Brumback

7. L. B. Cobb

8. J.S. Colley

9. K. W. Cook

10. R. B. Cook

11. D. G. Cope

12. L. T. Cusick

13. R. C. Durfee

14. R. A. Efyomson

15. J. L. Gibson

16. P. L. Goddard

17-18. R. L. Graham

19. C. S. Haase

20-21. P. A. Hamlett

22. D. D. Herr

23. R K. Holmes

24. D. S. Jones
25. B. L. Kimmel

26-27. A. L. King

28. J. A. Klein

29. J. R. Lyons

30. J. C. Massey

31. D. M. Matteo

32. M. E. Musolf

33. C. D. Nobles

34. P. T. Owen

35-36. P. D. Parr

- 37. D. H. Pike

38. A. S. Quist

39. C. T. Rightmire

40. W. K. Roy

41. B. E. Sample,

42. G. W. Suter

43. T. D. Taylor

44. J.W. Webb

45. C. J. Welsh

46. D. C. White

47. Central Research Library

48. ER Document Management Center-RC

49-50. D. J. Awl, JAYCOR, 601-D Scarboro Rd., Oak Ridge, TN 37831

51. A. C. Echternacht, The University of Tennessee, P.O. Box 1071, Knoxville, TN 37901

52. J. W. Evans, Tennessee Wildlife Resources Agency, Oak Ridge National Laboratory, Building 0907, Oak Ridge, TN 37831-6490

53. C. Hadden, SAIC, P.O. Box 2502, Oak Ridge, TN 37831

54. R. Hatcher, Tennessee Wildlife Resources Agency, Ellington Agricultural Center, P.O. Box 40747, Nashville, TN 37204

55. J. F. Heitman, JAYCOR, 601-D Scarboro Rd., Oak Ridge, TN 37831

56. F. J. McCormick, Ph.D., Department of Ecology and Evolutionary Biology, The University of Tennessee, 569, Dabney Hall, Knoxville, TN 37996-1610.

57. J. M. Mitchell, JAYCOR, 601-D Scarboro Rd., Oak Ridge, TN 37831

58-67. L. D. Pounds, JAYCOR, 601-D Scarboro Rd., Oak Ridge, TN 37831

68-70. B. A. Rosensteel, JAYCOR, 601-D Scarboro Rd., Oak Ridge, TN 37830

71. U.S. Fish and Wildlife Service, 446 Neal Street, Cookeville, TN 38501

72. C. Wenzel, SAIC, P.O. Box 2502, Oak Ridge, TN 37831

73. D. Withers, Tenneessee Department of Environment and Conservation, Division of Natural Heritage, 8th Floor, L\&C Tower, 401 Church Street, Nashville, TN 37243-0447

74. Dr. Bruce A Davis, NASA-Stennis Space Center, Science and Technology Lab, Stennis, MS 39529

75. Dr. Michael E Hodgson, Department of Geography, University of South Carolina, Columbia,SC 29208 
